
Z anglického originálu ConTEXt an Excursion přeložili Vít Zýka, Ján Buša, Jiří Hrbek, Martina Plachá a Petr Tesařík.

Překlad tohoto manuálu vznikl za podpory grantu Československého sdružení uživatelů TEXu (CSTUG, http: //www.cstug.cz). Kapitola věnovaná sazbě českých a slovenských textů a př́loha Další informační zdroje je původní text překladatelů. Děkujeme správcům serveru https://foundry.supelec.fr za hostování zdrojových textů pomocíSVN.

Tento dokument verze 6. prosince 2006 je generován pomocí nástrojů CONTEX, TEXEDIT, TEXUTIL a Web2C PDFTEX. Je sázen písmem Palladio. K testování jsme používali GHOSTSCRIPT a Acrobat Reader.

TEX a $\mathcal{A}_{\mathcal{M} S}$-TE $_{\mathrm{E}} \mathrm{X}$ jsou obchodní značky American Mathematical Society; METAFONT je obchodní značka AddisonWesley Publishing Company; PostScript, Portable Document Format a Acrobat jsou obchodní značky Adobe Systems Incorporated; DVIPSONE a DVIWINDO jsou obchodní značky Y\&Y Incorporated; IBM je obchodní značka International Business Machines Corporation; MSDOS je obchodní značka MicroSoft Corporation; všechna další jména výrobků jsou obchodní značky jejich výrobců.

(c) 1991-2006 PRAGMA ADE, Ridderstraat 27, 8061GH Hasselt, Nizozemsko, www.pragma-ade.com 

1 Jak vytvořit dokument

2 Jak zpracovat vstupní soubor

Vymezení dokumentu

27 Pozadí textu

78

$$
\text { Nadpisy }
$$

28 Pozadí stránky

79

29 Zarovnání

80

6 Odrážky a výčty

30 Interaktivní mód v elektronických dokumentech $\quad 81$

7 Sazba matematiky

31 Písmo a přepínače fontů

32 Složené znaky

33 Formátování stránky 94

9 Jednotky

34 Odsazení odstavců 98

10 Obrázky 28

11 Tabulky 34

12 Tabelace / formátování odstavce

102

36 Definování př́ikazů / maker 103

13 Sloupce

14 Poznámky pod čarou

37 Nezařazené

106

5 Definice pojmů

38 Externí moduly

119

39 Grafické rozšíření / METAPOST 122

16 Číslované poznámky

17 Orámování textu

41 Postup zpracování 123

18 Orámování odstavce

42 Pomocné soubory

43 Sazba českých/slovenských textů 125

20 Zalamování a číslování stránek 
2 


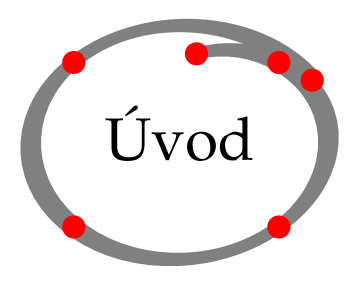

CONTEXT je inženýrský systém pro dokumentování založený na TEXu. TEX je sázecí systém a programovací jazyk zaměřený na sazbu a generování dokumentů. CONTEXT je snadno použitelný a umožňuje vytvářet složité tištěné i elektronické dokumenty.

Tento manuál popisuje možnosti CONTEXTu, popisuje dostupné př́kazy a jejich použití. ${ }^{1}$

CONTEXT je vyvíjen na praktických aplikacích: sazba a generování dokumentů počínaje jednoduchými beletristickými knihami a konče složitými technickými manuály a odbornými publikacemi v tištěné i elektronické podobě. Tento začátečnický manuál popisuje funkcionalitu CONTEXTu nezbytnou $\mathrm{k}$ formátování základních textových elementů používaných v manuálech nebo příručkách. CONTEXT je však schopný vytvářet mnohem více a pro toho, kdo se nespokojí s těmito základními funkcemi, je připraveno mnoho dalších detailnějších manuálů a jiných informací, Viz př́lohu A.

CONTEXT má lokalizovatelné rozhraní umožňující uživatelům pracovat s CONTEXTem v jejich vlastním jazyze. V současné době existuje rozhraní holandské, německé, anglické, italské, francouské, rumunské a také české. Tento manuál je dostupný v holandštině, němčině, angličtině a češtině.

${ }^{1}$ Všechny papírové a elektronické dokumenty o CONTEXTu jsou připraveny CONTEXTem. Všechny zdrojové texty těchto dokumentů jsou nebo budou elektronicky dostupné, aby umožnily vhled do práce s tímto systémem. 
4 


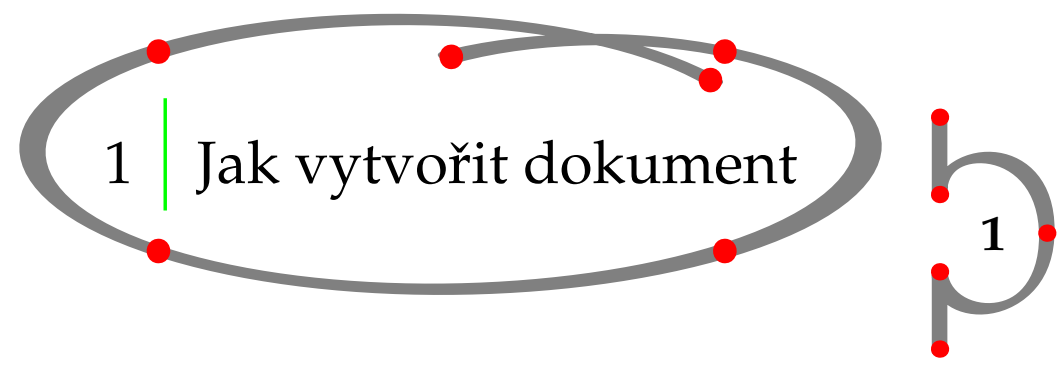

Řekněme, že chceme vytvořit jednoduchý dokument. Má nějakou strukturu a obsahuje titulní stranu, několik kapitol, sekcí a podsekcí. Přirozeně má také obsah a rejstřík.

CONTEXT dokáže takový dokument vytvořit automaticky, když mu poskytneme správný vstup ve formě souboru. Nejprve tedy musíme vytvořit vstupní soubor. Úplný název vstupního souboru se skládá ze jména a př́ípony. Jméno můžeme zvolit libovolné, ale př́ípona musí být tex. Když vytvoříme soubor s názvem mujs soubor. tex, nebudeme mít s během CONTEXTu žádné potíže.

Vstupní soubor může vypadat následovně:

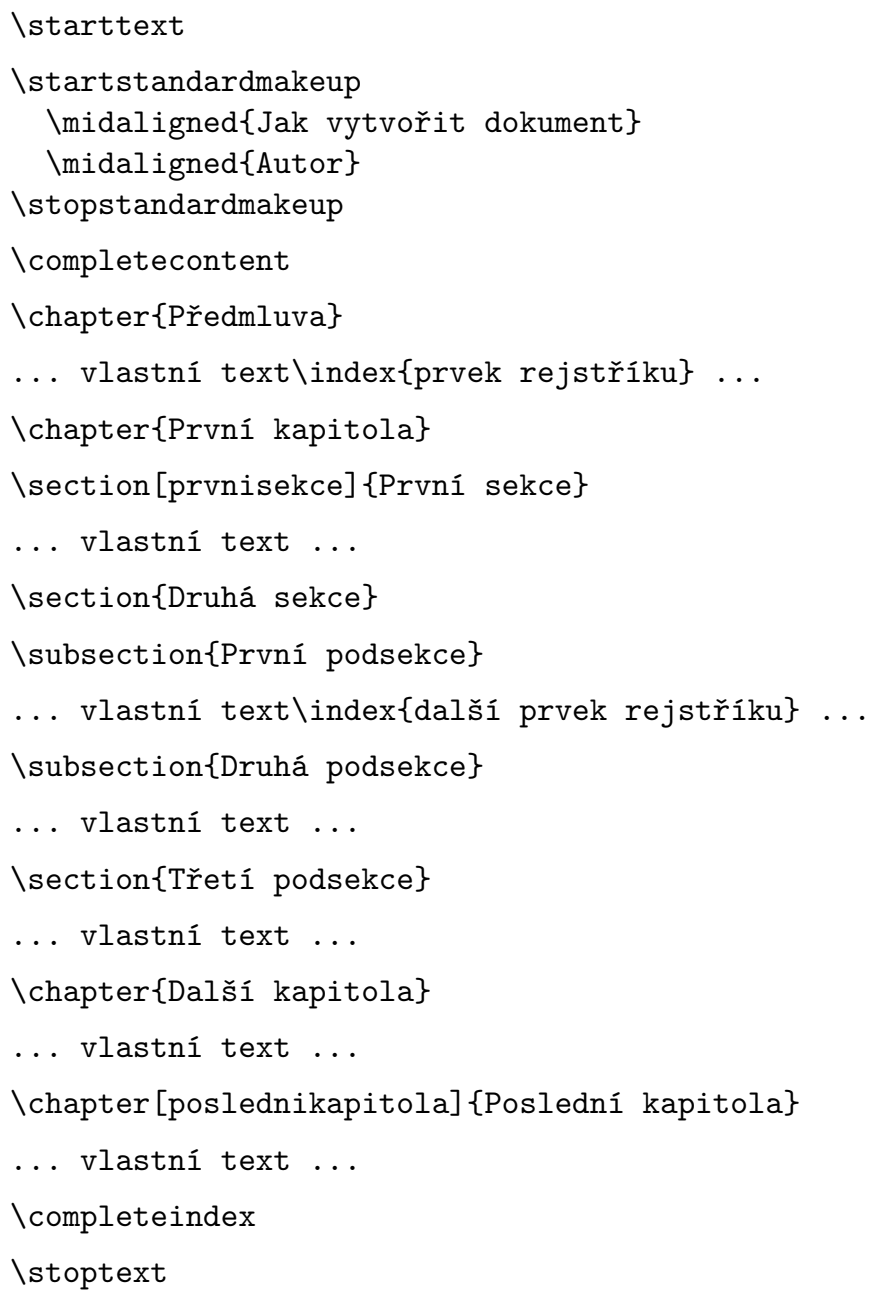


CONTEXT očekává na vstupu prostý soubor v kódování ASCII. Můžeme samožrejmě používat libovolný textový editor nebo procesor, ale nesmíme zapomenout, že CONTEXT dokáže načíst jenom ASCII vstup. Většina editorů nebo textových procesorů umí exportovat soubory do prostého ASCII.

Vstupní soubor by měl obsahovat text, který chceme zpracovat programem CONTEXT, a př́kazy CONTEXTu. Př́́kazy CONTEXTu začínají znakem \. Př́́kazem \starttext označujeme začátek textu. Oblast před příkazem \starttext se nazývá deklarační oblast a používá se k definování nových př́íkazů a nastavení vzhledu dokumentu.

Za příkazem obvykle následuje dvojice hranatých závorek [] a/nebo levá a pravá složená závorka \{\}. V sekvenci \chapter[poslednikapitola] \{Posledni kapitola\} např́klad povel \chapter po CONTEXTu požaduje, aby vykonal několik činností týkajících se úpravy, typografie a struktury. Těmito činnostmi může být:

1. začátek nové strany,

2. zvětšení počítadla kapitol o jednotku,

3. umístění čísla kapitoly před její název,

4. vynechání určitého vertikálního prostoru,

5. použití většího písma nebo

6. uložení názvu kapitoly (a čísla stránky) do obsahu.

Tyto činnosti budou vykonány s argumentem zadaným mezi levou a pravou svorkou: Poslední kapitola.

Dosud jsme se nezmínili o parametru [poslednikapitola] mezi hranatými závorkami. Je to návěští s referenčním jménem, které je možné použít pro odkaz na odpovídající kapitolu. Toho se docílí dalšími př́kazy CONTEXTu: \in\{kapitole\} [poslednikapitola] vysází číslo kapitoly, zatímco \about [poslednikapitola] vrátí její název.

Seznam činností tedy může být rozšířen o:

7. zavedení referenčního jména poslednikapitola, které reprezentuje číslo a název kapitoly (a uloží se pro pozdější použití).

Dalším činnostem týkajícím se průběžných nadpisů, nastavení čítačů nebo interaktivních vlastností se nyní nebudeme věnovat.

Když necháme CONTEXT zpracovat uvedený vzorový soubor, získáme velmi jednoduchý dokument s několika očíslovanými kapitolami a s hlavičkami oddílů.

Během zpracování souboru se CONTEXT stará o spoustu věcí. Jednou z nich je např́íklad číslování stránek. Ovšem k vytvoření obsahu CONTEX potřebuje znát čísla stránek, která mu při prvním průběhu zatím nejsou známá. Proto musíme tento soubor zpracovat dvakrát (dvojprůchodová úloha). K uložení těchto a podobných informací CONTEXT vytvoří několik pomocných souborů, které se pak zpracovávají programem TEXUTIL. V některých prrípadech musíme vstupní soubor zpracovat třikrát (trojprůchodová úloha). Je také možné spouštět CONTEXT z příkazové řádky příkazem TEXEXEC. Tento skript, dřive napsaný v PERLu dnes v RUBY, se postará i o vícenásobné průchody. TEXEXEC je součástí standardní distribuce CONTEXTu. 


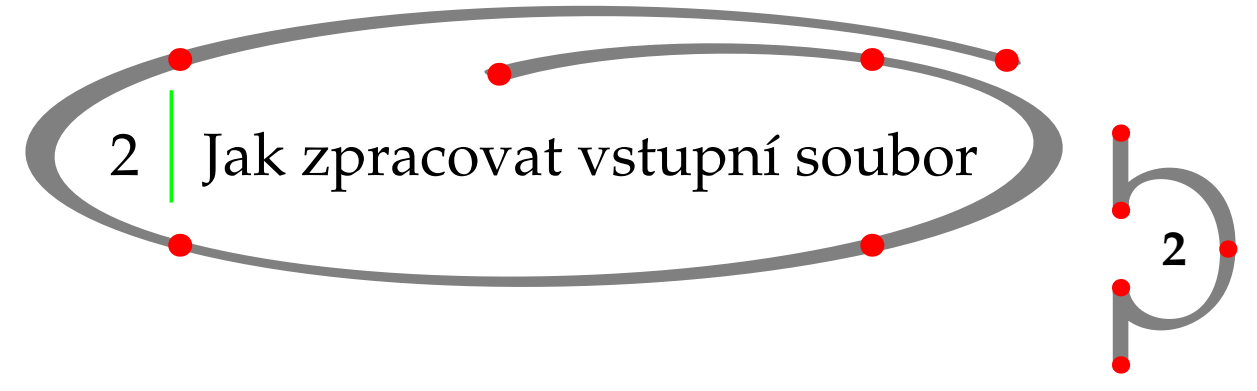

Jestliže chceme zpracovat vstupní soubor CONTEXTu, můžeme na příkazové řádce napsat:

context jmenosouboru

Dostupnost dávkového př́ikazu context závisí na použitém systému. Na to, jakým př́kazem se spouští CONTEXT, se zeptejte správce svého systému. Pokud se náš soubor jmenuje mujsoubor . tex, může to být:

context mujsoubor

nebo, když je řádně nainstalován TEXMFSTART a TEXEXEC:

texmfstart texexec --pdf mujsoubor

Př́íponu .tex není potřeba zadávat.

Po stlačení klávesy Enter začne zpracovávání. CONTEXT vypisuje na obrazovku informace o průběhu zpracování. Když je soubor zpracován úspěšně, znovu se objeví výzva v př́ikazové ráádce a CONTEXT vytvoří soubor dvi nebo pdf.

Jestliže zpracování úspěšné není - například proto, že jsme napsali \stptext namísto \stoptext — CONTEXT na obrazovku vypíše znak ? a oznámí nám, že právě narazil na chybu. Poskytne nám základní informace o druhu chyby a číslo řádky, na kterém se chyba projevila.

V okamžiku, kdy se objeví znak ? můžeme napsat:

$\mathrm{H} \quad$ pro nápovědu $\mathrm{k}$ chybě,

I pro vložení opraveného př́íkazu CONTEXTu,

Q pro ignorování chyb bez výpisu,

$\mathrm{R} \quad$ pro ignorování chyb s výpisem,

$\mathrm{X}$ pro ukončení běhu, nebo

Enter pro ignorování chyby.

Nejčastěji stlačíme klávesu Enter a zpracování bude pokračovat. Pak můžeme editovat vstupní soubor a chybu odstranit.

Některé chyby způsobí, že se na obrazovku vypíše znak * a současně se zpracování zastaví. To je důsledek závažné chyby ve vstupním souboru. Tuto chybu nemůžeme ignorovat a jedinou možností je napsat \stop nebo Ctrl Z. Program se ukončí a my můžeme chybu odstranit.

Během zpracování vstupního souboru nás CONTEXT také informuje o činnostech, které na našem dokumentu provádí. Zobrazuje např́ílad čísla stránek a informace o jednotlivých krocích. Mimoto vypisuje varování. Ta se týkají typografie a oznamují nám neúspěšné zalomení řádku. Veškeré informace o zpracování se ukládají do záznamového souboru s př́íponou .log, kde lze přezkoumat varování i chyby a nalézt čísla př́slušných řádek vstupního souboru.

Při úspěšném zpracování CONTEXT vytvoří nový soubor s příponou .dvi nebo . pdf, v našem příkladu bude tedy vytvořen soubor mujsoubor. dvi nebo mujsoubor. pdf. Zkratka dvi znamená 


\section{Zvláštní znaky}

Device Indepent (nezávislý na zařízení). To znamená, že soubor může být dále převeden patřičným ovladačem PostScriptové (PS) tiskárny na soubor vhodný k tisku nebo k prohlížení. Zkratka PDF znamená Portable Document Format (přenosný formát dokumentu). Je to formát pro tisk a prohlížení, nezávislý na operačním systému.

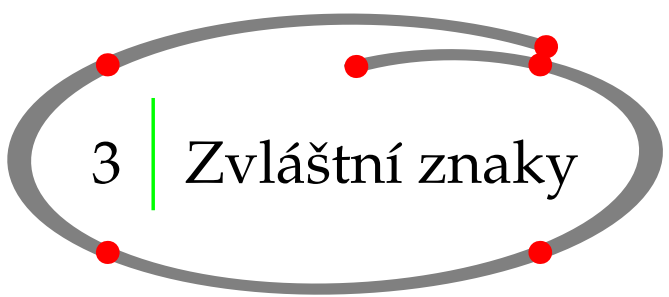

Už jsme si ukázali, že každý povel CONTEXTu je uvozen znakem \(obrácené lomítko). To znamená, že \má pro CONTEXT zvláštní význam. Kromě \existují ještě další znaky, které vyžadují zvláštní pozornost, pokud je chceme použít v doslovném ,verbatim' módu nebo v módu textovém. Tabulka 3.1 uvádí přehled těchto zvláštních znaků a povely potřebné $\mathrm{k}$ jejich vysázení.

\begin{tabular}{ccc|cc}
\hline \multirow{2}{*}{ Zvláštní znak } & \multicolumn{2}{c}{ Verbatim } & \multicolumn{2}{c}{ Text } \\
& Vstup & Vysází se & Vstup & Vysází se \\
\hline$\#$ & $\backslash$ type $\{\#\}$ & $\#$ & $\backslash \#$ & $\#$ \\
$\$$ & $\backslash$ type $\{\$\}$ & $\$$ & $\backslash \$$ & $\$$ \\
$\&$ & $\backslash$ type $\{\&\}$ & $\&$ & $\backslash \&$ & $\&$ \\
$\%$ & $\backslash$ type $\{\%\}$ & $\%$ & $\backslash \%$ & $\%$ \\
\hline
\end{tabular}

Tabulka 3.1 Zvláštní znaky (1).

Další znaky mají zvláštní význam při sázení matematických výrazů a některé lze použít jedině v matematickém módu (viz kapitolu 7).

\begin{tabular}{ccc|cc}
\hline \multirow{2}{*}{ Zvláštní znak } & \multicolumn{2}{c}{ Verbatim } & \multicolumn{2}{c}{ Text } \\
& Vstup & Vysází se & Vstup & Vysází se \\
\hline+ & $\backslash$ type $\{+\}$ & + & $\$+\$$ & + \\
- & $\backslash$ type $\{-\}$ & - & $\$-\$$ & - \\
$=$ & $\backslash$ type $\{=\}$ & $=$ & $\$=\$$ & $=$ \\
$<$ & $\backslash$ type $\{<\}$ & $<$ & $\$<\$$ & $<$ \\
$>$ & $\backslash$ type $\{>\}$ & $>$ & $\$>\$$ & $>$ \\
\hline
\end{tabular}

Tabulka 3.2 Zvláštní znaky (2). 


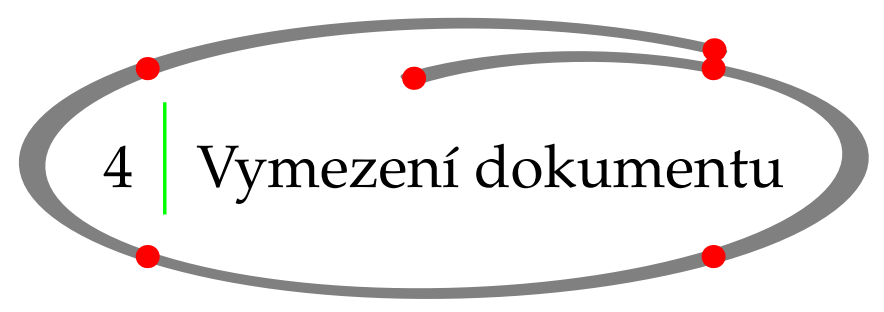

Každý dokument začíná povelem \starttext a je ukončen povelem \stoptext. Veškerý textový vstup je umístěn mezi tyto dva povely a jedině zde jej CONTEXT bude zpracovávat.

Nastavení parametrů se umíst'uje do deklarační oblasti, která se nachází těsně před povelem \starttext.

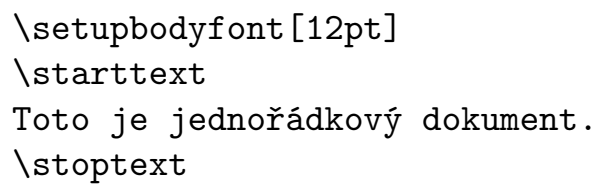

Uvnitř \starttext $\cdots$ \stoptext lze dokument rozdělit na čtyři hlavní úseky:

1. úvodní část (angl. front matter)

2. hlavní část (angl. body matter)

3. závěrečná část (angl. back matter)

4. př́lohy (angl. appendices)

Jednotlivé úseky se definují následovně:

$\begin{array}{lll}\text { \startfrontmatter } & \ldots & \text { \stopfrontmatter } \\ \text { Istartbodymatter } & \ldots & \text { \stopbodymatter } \\ \text { Istartbackmatter } & \ldots & \text { \stopbackmatter } \\ \text { Istartappendices } & \ldots & \text { \stopappendices }\end{array}$

V úvodní a v závěrečné části vytváří povel \chapter nečíslovaná záhlaví v obsahu. Tyto úseky se používají nejčastěji pro obsah, seznam obrázků a tabulek, předmluvu, poděkování apod. Strany jsou zde často číslovány římskými číslicemi.

Úsek př́loh se používá - kdo by to byl řekl? - pro přílohy. Záhlaví zde mohou být sázena jiným způsobem, např. \chapter může místo čísel používat písmena abecedy.

Styl sekcí lze nastavit pomocí:

\setupsectionblock [....] $[\ldots, . \stackrel{2}{.} ., \ldots]$

1 IDENTIFIER

2 number $=$ yes no

page $=$ yes right

before $=$ COMMAND

after $=$ COMMAND 
Nadpisy

\section{Nadpisy}

Struktura dokumentu je určena nadpisy. Nadpisy (záhlaví) se vytvářejí pomocí povelů uvedených v tabulce 5.1:

\begin{tabular}{ll}
\hline Číslovaný nadpis & Nečíslovaný nadpis \\
\hline \chapter & \title \\
\section & \subject \\
\subsection & \subsubject \\
\subsubsection & \subsubsubject \\
$\ldots$ & $\ldots$ \\
\hline
\end{tabular}

Tabulka 5.1 Nadpisy.

\chapter $[\ldots, \ldots]\{.2$.

OPTIONAL

1 REFERENCE

2 TEXT

\section $[\ldots, \ldots]\{.2$. OPTIONAL

1 REFERENCE

2 TEXT

$\backslash$ subsection $[\ldots, \ldots]\{.2$.

OPTIONAL

1 REFERENCE

2 TEXT 
$\backslash$ title $\underset{\text { OPTIONAL }}{[\ldots, \ldots]}\{\stackrel{2}{2}$.

1 REFERENCE

2 TEXT

Subject $[\ldots, \ldots]\{.2$. OPTIONAL

1 REFERENCE

2 TEXT

$\backslash$ subsubject $[\ldots, \ldots]\{.2$. OPTIONAL

1 REFERENCE

2 TEXT

Tyto povely vytvoří nadpis $\mathrm{v}$ předem dané velikosti a řezu písma a přidají vertikální mezeru před a za nadpis.

Povelům pro nadpis je možné zadat několik parametrů, jako např.:

\title[hasselt-v-noci] \{Hasselt $v$ noci\}

a

\title\{Hasselt v noci\}

Hranaté závorky jsou nepovinné a používají se pro odkazování uvnitř dokumentu. Pokud se chceme odkázat na tento nadpis, můžeme napsat např. \at\{str.\} [hasselt-v-noci] .

Tyto nadpisy lze samozřejmě přizpůsobit našemu vkusu a dají se dokonce definovat vlastní nadpisy. To se dělá povelem \setuphead a \definehead. 


\section{Nadpisy}

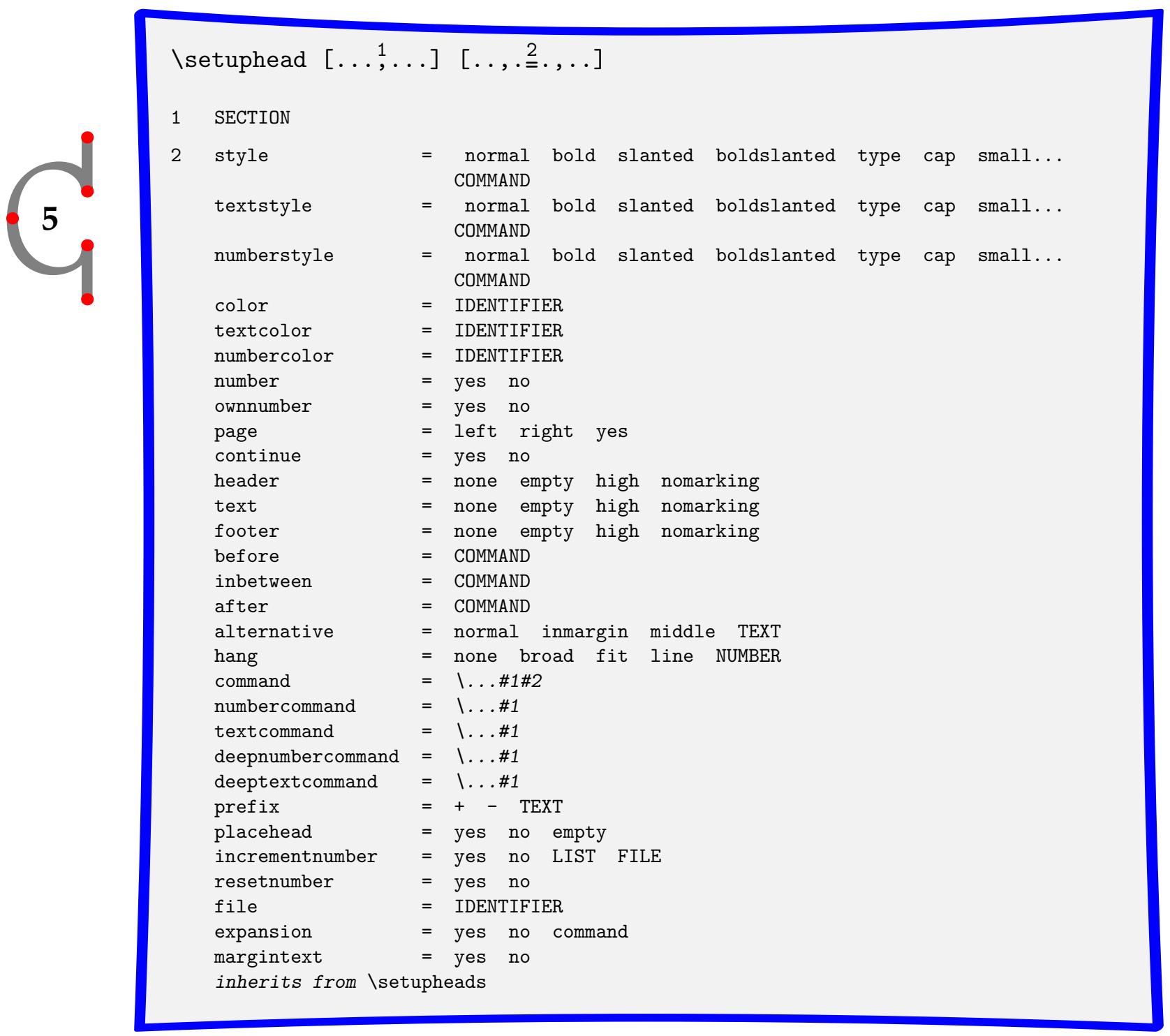

\definehead [...] [..2.]

1 IDENTIFIER

2 SECTION

\footnotetext{
\definehead

[mujnadpis]

[section]

\setuphead

[mujnadpis]

[numberstyle=bold, textstyle=bold,
} 


\section{Odrážky a výčty}

bef ore $=\backslash$ hairline $\backslash$ blank, after $=\backslash$ nowhitespace $\backslash$ hairline $]$

$\backslash$ mujnadpis [nadpis] \{Hasselt má velkou publicitu\}

Tím se definuje nový typ nadpisu \mujnadpis, který zdědí vlastnosti \section. Vypadal by nějak takto:

\subsection{Hasselt má velkou publicitu}

Ještě o jednom povelu bysme měli vědět, a to o \setupheads. Používá se k nastavení číslování pro číslované nadpisy. Pokud napíšeme:

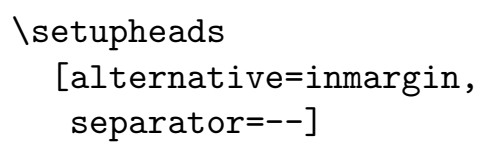

pak se všechna čísla objeví na okraji. Sekce 1.1 by vypadala jako 1-1.

Povely jako \setupheads se píšou do deklarační oblasti vstupního souboru.

$\backslash$ setupheads $[\ldots, . * ., \ldots]$

* sectionnumber

separator $\quad=$ TEXT

stopper $\quad=$ TEXT

align $=$ inner outer left right middle normal no yes

aligntitle $=$ yes float no

tolerance $\quad=$ verystrict strict tolerant verytolerant stretch

indentnext $=$ yes no

command $\quad=1 \ldots \# 1 \# 2$

margin $\quad=$ DIMENSION

Jedním ze způsobů, jak rozčlenit text, je vyjmenování nebo shrnutí jednotlivých položek. Příkaz pro vytvoření seznamu vypadá takto: 


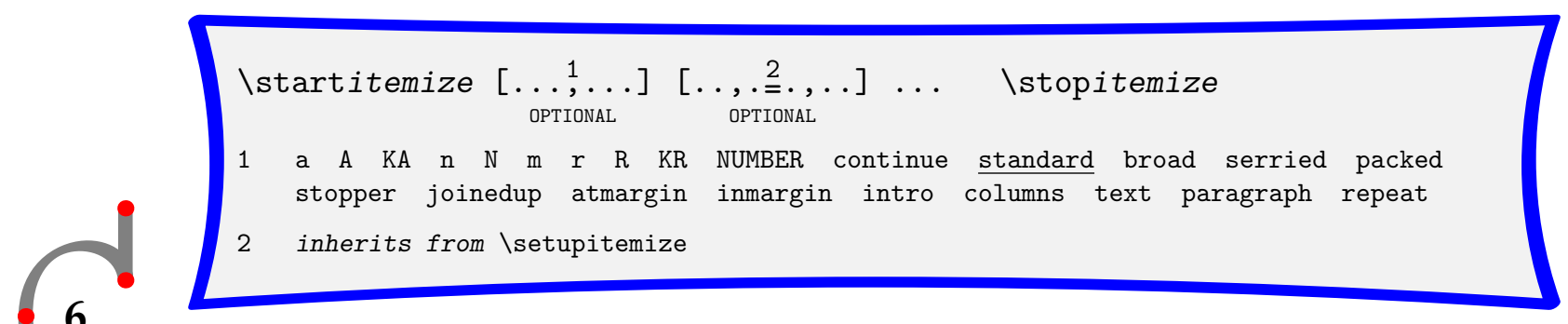

Příklad:

Istartitemize [R, packed, broad]

\item Hasselt byl založen ve 14.století.

\item Hasselt je známý jako tzv. hanzovní město.

\item Jméno Hasselt vychází z názvu stromu.

\stopitemize

Uvnitř dvojice \startitemize ... \stopitemize začínáme každou novou položku př́kazem \item a za \item nezapomeňme na mezeru. $V$ našem př́kladu parametr $R$ specifikuje římské číslování a packed minimální mezeru mezi řádky. Parametr broad zajistí rozumnou horizontální mezeru mezi značkou a textem. Náš př́klad by vypadal:

I. Hasselt byl založen ve 14.století.

II. Hasselt je známý jako tzv. hanzovní město.

III. Jméno Hasselt vychází z názvu stromu.

Rozčlenění textu do položek je dvoufázový proces. To znamená, že pro získání optimálního rozložení budete muset svůj soubor překompilovat dvakrát. V závorkách je obsažena informace o symbolu odrážky a lokální nastavení proměnných.

\begin{tabular}{ll}
\hline Argument & Značka před položkou \\
\hline 1 & $\bullet$ \\
2 & - \\
3 & $\star$ \\
$\vdots$ & $\vdots$ \\
$\mathrm{n}$ & $1234 \cdots$ \\
$\mathrm{a}$ & a b c d $\cdots$ \\
A & A B C D $\cdots$ \\
r & i ii iii iv $\cdots$ \\
R & I II III IV $\cdots$ \\
\hline
\end{tabular}

Tabulka 6.1 Nastavení

formátu odrážek.

Můžete také nadefinovat svoji vlastní značku pomocí př́kazu \definesymbol. Vyzkoušejte např́klad

\definesymbol[5] [\$ \clubsuit\$]

Sstartitemize [5, packed]

\item Hasselt byl zbudován na písečném přesypu. 


\section{Odrážky a výčty}

\item Hasselt leží na soutoku dvou řek.

\stopitemize

Dostanete pak tento výstup:

* Hasselt byl zbudován na písečném přesypu.

* Hasselt leží na soutoku dvou řek.

Někdy je potřeba mít jednotlivé položky nečíslované. V takovém případě použijte místo \item príkaz \head.

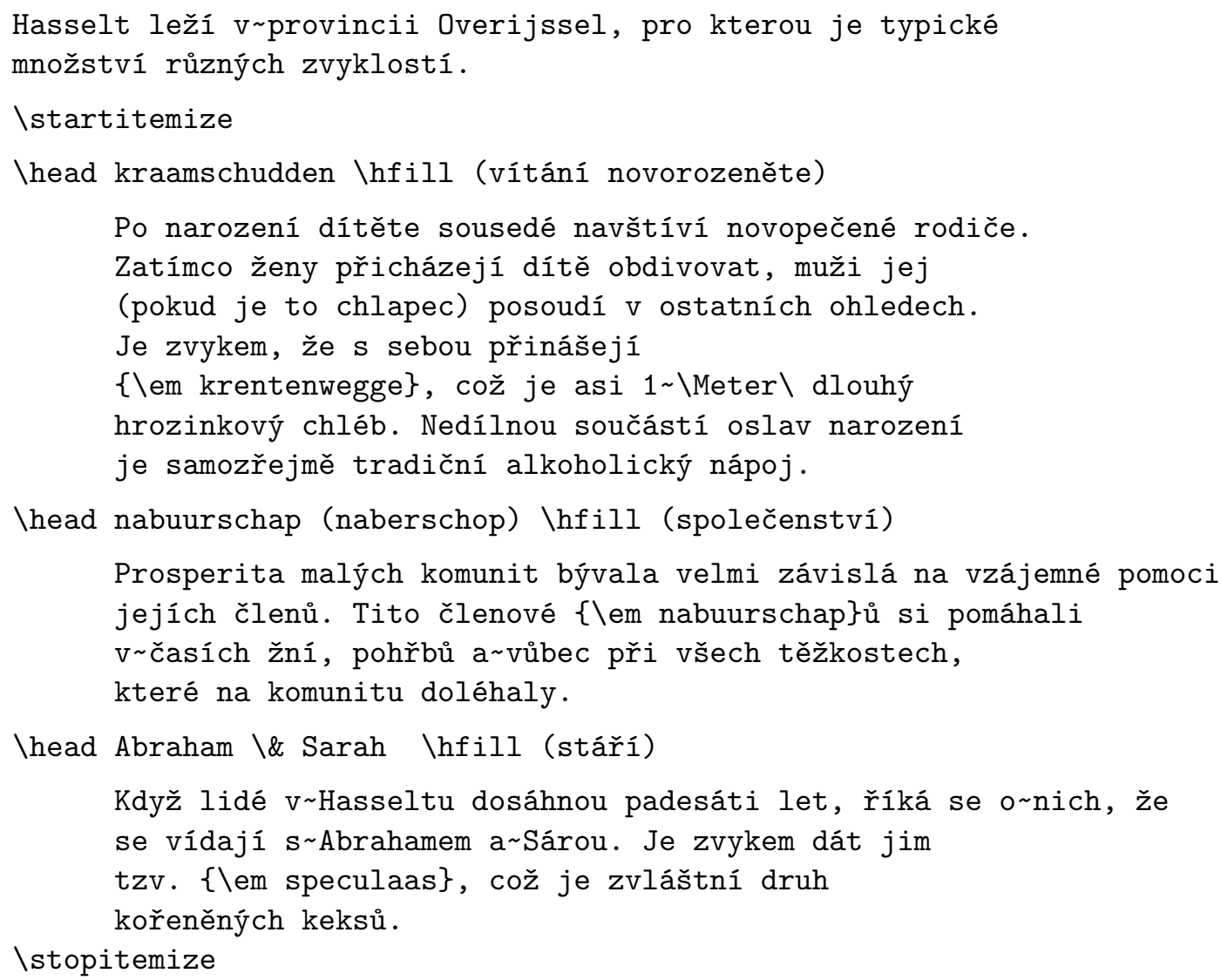

Způsob, jakým se př́kaz \head vysází, může být ovlivněn pomocí \setupitemize. V případě zlomu stránky, se \head objeví vždy na nové stránce. (Př́kaz \Meter bude vysvětlen v kapitole 9.)

Př́klad o starých zvycích vypadá takto:

Hasselt leží v provincii Overijssel, pro kterou je typické množství různých zvyklostí.

- kraamschudden

(vítání novorozeněte)

Po narození dítěte sousedé navštíví novopečené rodiče. Zatímco ženy přicházejí dítě obdivovat, muži jej (pokud je to chlapec) posoudí v ostatních ohledech. Je zvykem, že s sebou přinášejí krentenwegge, což je asi 1 m dlouhý hrozinkový chléb. Nedílnou součástí oslav narození je samožrejmě tradiční alkoholický nápoj. 
- nabuurschap (naberschop)

(společenství)

Prosperita malých komunit bývala velmi závislá na vzájemné pomoci jejích členů. Tito členové nabuurschapů si pomáhali v časích žní, pohřbů a vůbec při všech těžkostech, které na komunitu doléhaly.

- Abraham \& Sarah

Když lidé v Hasseltu dosáhnou padesáti let, říká se o nich, že se vídají s Abrahamem a Sárou. Je zvykem dát jim tzv. speculaas, což je zvláštní druh kořeněných keksů.

Parametry pro nastavení způsobu zobrazení položek jsou uvedeny v tabulce 6.2.

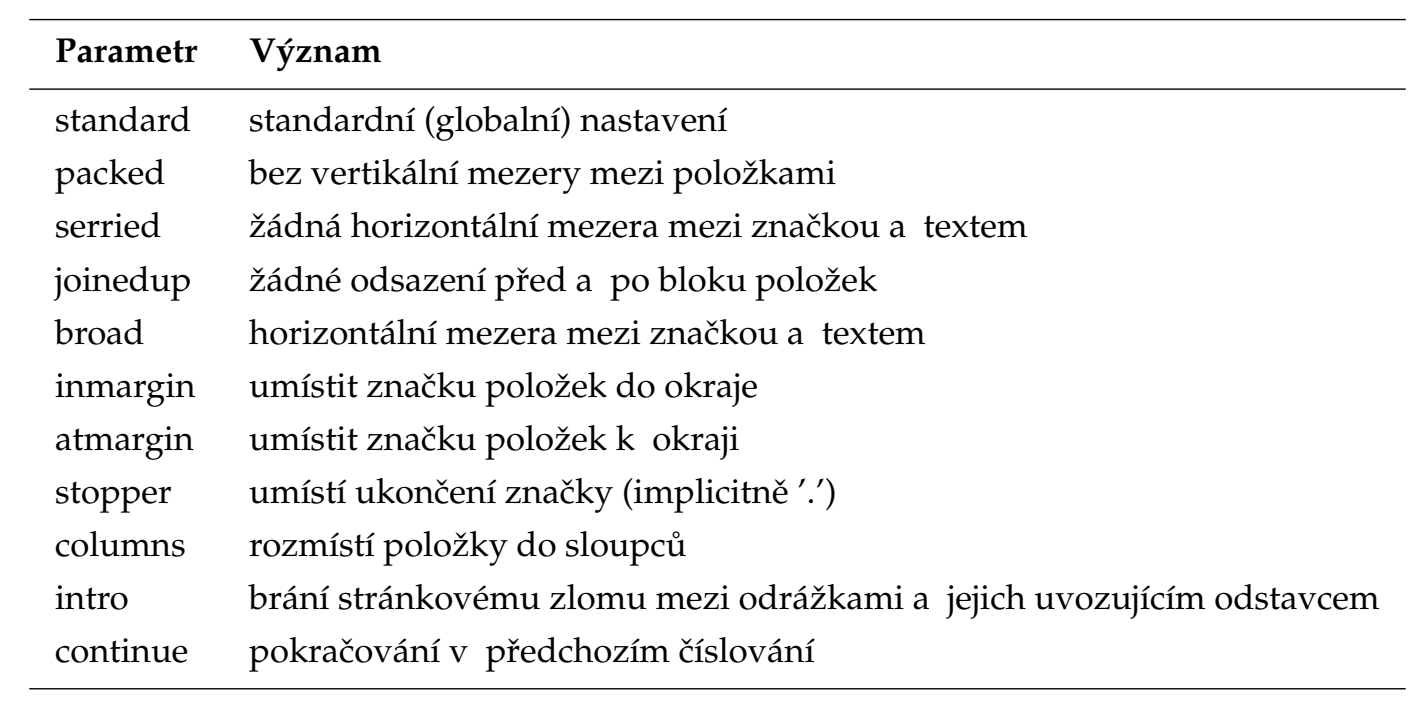

Tabulka 6.2 Parametry pro \startitemize.

Způsob zobrazení položek je sice možné měnit u každého \startitemize, ale pro zachování jednotného vzhledu je vhodné jej nastavit pro celý dokument pomocí \setupitemize.

Parameter columns se používá společně s označením počtu, například kód:

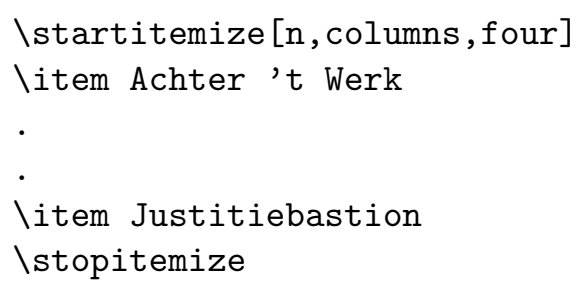

vysází:
1. Achter' $\mathrm{t}$ Werk
4. Eikenlaan
7. Heerengracht
10. Julianakade
2. Baangracht
5. Eiland
8. Hofstraat
11. Justitiebastion
3. Brouwersgracht
6. Gasthuisstraat
9. Hoogstraat

Někdy chceme po krátké přestávce v číslování položek pokračovat. Pak stačí napsat například Istartitemize [continue, columns, three, broad] a číslování bude pokračovat ve formátu tř́i sloupců. 
12. Kaai

13. Kalverstraat

14. Kastanjelaan

15. Keppelstraat

16. Markt

17. Meestersteeg
18. Prinsengracht

19. Raamstraat

20. Ridderstraat

21. Rosmolenstraat

22. Royenplein

23. Van Nahuijsweg
24. Vicariehof

25. Vissteeg

26. Watersteeg

27. Wilhelminalaan

28. Ziekenhuisstraat

Isetupitemize $\underset{\text { OPTIONAL }}{[.1 .]}\left[\underset{\text { OPTIONAL }}{[., \ldots]}\left[\underset{\text { OPTIONAL }}{2}\left[\begin{array}{l}3 \\ =\end{array}\right]\right.\right.$

1 NUMBER each

2 standard broad serried packed unpacked stopper joinedup atmargin inmargin autointro loose repeat SECTION paragraph intext random

3 margin $=$ no standard DIMENSION

leftmargin $=$ no standard DIMENSION

rightmargin $=$ no standard DIMENSION

width $\quad=$ DIMENSION

distance $\quad=$ DIMENSION

factor $\quad=$ NUMBER

items $\quad=$ NUMBER

start $\quad=$ NUMBER

before $\quad=$ COMMAND

inbetween $\quad=$ COMMAND

after $\quad=$ COMMAND

left $\quad=$ TEXT

right $\quad=$ TEXT

beforehead $=$ COMMAND

afterhead $=$ COMMAND

headstyle $=$ normal

marstyle

symstyle

= normal bold slanted boldslanted type cap small... COMMAND

bold slanted boldslanted type cap small... COMMAND

stopper

$\mathrm{n}$

$=$ TEXT

symbol $=$ NUMBER

align $=$ inner outer left right middle normal no yes

indentnext $=$ yes no

Vnořené položky se automaticky vysázejí správně. Pokud například napíšete:

V Nizozemí mohou výši celé řady daní určovat města, takže životní náklady se město od města liší. Rozdíly dosahují

až 50\, \\% v daních jako:

\setupitemize [2] [width=5em]

lstartitemize [n]

\item Daň $z \sim$ nemovitostí.

Daně $z \sim$ nemovitostí se dělí do dvou složek:

\startitemize [a,packed]

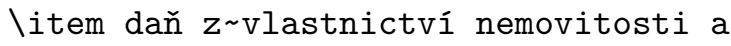

\item daň $z \sim n a ́ j m u$.

\stopitemize 
Pokud nemovitost není v nájmu, platí obě složky vlastník.

\item Poplatek za psa.

Vlastník jednoho nebo více psů platí poplatek. Pokud pes zemře, nebo je prodán, je vlastník povinen nahlásit to na radnici.

\stopitemize

potom horizontální mezeru mezi značkou a textem vnořené položky lze nastavit pomocí: Ssetupitemize [2] [width=5em] .

Náš príklad pak bude vypadat takto:

V Nizozemí mohou výši celé řady daní určovat města, takže životní náklady se město od města liší. Rozdíly dosahují až 50 \% v daních jako:

1. Daň z nemovitostí.

Daně z nemovitostí se dělí do dvou složek:

a. daň z vlastnictví nemovitosti a

b. daň z nájmu.

Pokud nemovitost není v nájmu, platí obě složky vlastník.

2. Poplatek za psa.

Vlastník jednoho nebo více psů platí poplatek. Pokud pes zemře, nebo je prodán, je vlastník povinen nahlásit to na radnici.

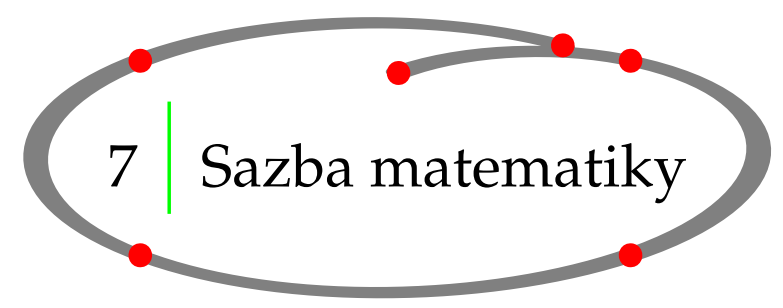

\section{1 Úvod}

TEX je především program pro sazbu matematiky. Přesto tato kapitola týkající se sazby matematiky není rozsáhlá, jak byste možná očekávali. Pokud potřebujete v TEXu sázet vzorce, doporučujeme vám ke studiu: ${ }^{2}$

- The $T_{E} X B o o k$, autor: D. E. Knuth

- The Beginners Book of $T_{E} X$, autoři: S. Levy a R. Seroul

Kromě toho o sazbě matematických rovnic pojednává CONTEXTový magazín ,My Way: Using \startalign and friends' od Aditya Mahajana, viz př́lohu A.

${ }^{2} \mathrm{~V}$ tomto manuálu se při sazbě matematiky opíráme o knížku $T_{E} X n i q u e s$, kterou napsal Arthur Samuel. 


\subsection{Sazba matematiky}

Zvyklosti pro sazbu běžného a matematického textu se obvykle liší. TEX tyto zvyklosti ,zná‘ a během vytváření dokumentu je přesně aplikuje. Pokud je požadována vysoká kvalita matematické sazby, můžeme se na $\mathrm{TE}_{\mathrm{E} X}$ plně spolehnout.

Několik zvyklostí pro sazbu matematiky:

1. Znaky jsou sázeny v matematicke kurzive (neplést s běžnou kurzívou při použití fontů).

2. Užívají se symboly jako řecké znaky $(\alpha, \chi)$ a matematické značky $(\leq, \geq, \in)$.

3. Délky mezer jsou také jiné než v běžném textu.

4. V matematických výrazech se také užívá jiný způsob zarovnání textu.

5. Horní a dolní indexy jsou umístěny automaticky. Například: $a_{c}^{b}$.

6. Určité symboly mají různý vzhled podle toho, zda jsou uvedeny ve vnitřním nebo v display matematickém módu.

Při sazbě matematiky musíte pracovat $v$ tak zvaném matematickém módu, ve kterém jsou výrazy definovány pomocí př́ḱkazů plain $\mathrm{T}_{\mathrm{E}} \mathrm{Xu}$.

Matematický mód má dvě alternativy: vnitřní matematický mód a display matematický mód. Vnitřní matematický mód je ohraničen znaky \$ a \$, zatímco display mód je aktivován pomocí \$ a $\$$.

Město Hasselt pokrývá plochu $42,05 \backslash$ Square $\backslash$ Kilo \Meter.
Pokud budeme uvažovat kruhovou oblast této velikosti
s hasseltským tržištěm v veometrickém středu $\$ T \$$, můžeme
spočitat průměr této oblasti pomocí vzorce $\$\{\{1\} \backslash$ \over $\{4\}\} \backslash p i d^{\sim} 2 \$$.

Tento text bude vypadat po vysázení takto:

Město Hasselt pokrývá plochu $42,05 \mathrm{~km}^{2}$. Pokud budeme uvažovat kruhovou oblast této velikosti $\mathrm{s}$ hasseltským tržištěm $\mathrm{v}$ geometrickém středu $T$, můžeme spočítat průměr této oblasti pomocí vzorce $\frac{1}{4} \pi d^{2}$.

Větší množství \{\} (složených závorek) ve výrazu $\frac{1}{4} \pi d^{2}$ je potřeba pro určení priority jednotlivých operací. Pokud zapomeneme na vnější závorky a zapíšeme: $\$\{1\} \backslash$ over $\{4\} \backslash p i \quad d^{`} 2 \$$, dostaneme nežádoucí výsledek: $\frac{1}{4 \pi d^{2}}$.

Písmena a číslice jsou sázena ve třech velikostech (stylech): velikost textu $a+b$, velikost indexu (script): $a+b$ a velikost indexu $\mathrm{v}$ indexu (scriptscript) ${ }_{a+b}$. Velikost lze ovlivnit př́kazy Iscriptstyle a \scriptscriptstyle.

Symboly jako $\int$ a $\sum$ vypadají jinak ve vnitřním a jinak v display matematickém módu. Pokud napíšeme $\$ \backslash$ sum $_{-}\{\mathrm{n}=1\}^{\frown}\{\mathrm{m}\} \$$ nebo $\$ \backslash$ int_ $\{-\backslash$ infty $\} \backsim\{+\backslash$ infty $\} \$$, dostaneme $\sum_{n=1}^{m}$ a $\int_{-\infty}^{+\infty}$. To samé v display módu: $\$ \$ \backslash$ sum_ $\{n=1\} \sim\{m\} \$$ a $\$ \$ \backslash$ int_ $\{-\backslash$ infty $\}-\{+\backslash$ infty $\} \$$ však bude vypadat takto:

$$
\sum_{n=1}^{m} \mathrm{a} \int_{-\infty}^{+\infty}
$$

Pomocí př́kazů \nolimits a \limits můžeme ovlivnit vzhled symbolů \sum a \int:

$$
\sum_{n=1}^{m} \text { a } \int_{-\infty}^{+\infty}
$$


Pro sazbu zlomků můžeme použít příkaz \over. V CONTEXTu můžeme používat také alternativu \frac. Např́ílad pro vysázení $\frac{a}{1+b}+c$ stačí zapsat: $\$ \backslash f \operatorname{rac}\{a\}\{1+b\}+c \$$.

Další prríkazy pro umístění různých částí výrazu nad sebe:

$\begin{array}{llll}\text { Vatop } & \$\{\mathrm{a}\} \backslash \text { Vatop }\{\mathrm{b}\} \$ & a & \\ \text { lchoose } & \$\{\mathrm{n}+1\} \backslash \text { lchoose }\{\mathrm{k}\} \$ & & \left(\begin{array}{c}n+1 \\ k\end{array}\right) \\ \text { lbrack } & \$\{\mathrm{~m}\} \backslash \text { brack }\{\mathrm{n}\} \$ & {\left[\begin{array}{c}m \\ n\end{array}\right]} & \\ \text { lbrace } & \$\{\mathrm{~m}\} \backslash \text { brace }\{\mathrm{n}-1\} \$ & & \left\{\begin{array}{c}m \\ n-1\end{array}\right\}\end{array}$

TEX může přizpůsobit velikost závorek jako ( ) a \{\} automaticky, pokud levou závorku předchází př́kaz \left a podobně pravou \right. Např́klad zápis $\$ \$ 1+\backslash \operatorname{left}\left(\backslash\right.$ frac $\{1\}\left\{1-\mathrm{x}^{`}\{\mathrm{x}-\right.$ $2\}\} \backslash$ right) $\leadsto$ 3\$ bude vypadat:

$$
1+\left(\frac{1}{1-x^{x-2}}\right)^{3}
$$

Sazby horního a dolního indexu dosáhneme pomocí ,_' a , ^’. Tyto značky mají vliv pouze na první následující znak, takže víceznakové indexy je nutné ohraničovat složenýma závorkama \{\}.

V určitých situacích mohou být závorky zvětšeny pomocí př́kazů \bigl, \Bigl, \biggl, \Biggl a jejich pravostranných ekvivalentů. Pokud to nestačí, tak ještě větších závorek můžeme dosáhnout spoluprací prríkazů \left a \right s konstrukcí \vbox. Více než popis to objasní příklad,

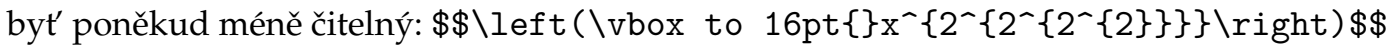

$$
\left(x^{2^{2^{2^{2}}}}\right)
$$

V display matematickém módu podléhají automatickému přizpůsobení velikosti následující sym-

\begin{tabular}{|c|c|c|c|c|}
\hline$\backslash$ lfloor & L \langle & $<$ Ivert & | & \downarrow \\
\hline \rfloor & \rangle & VVert & $\|$ & \Downarrow \\
\hline \lceil & 「 / & \uparrow & $\uparrow$ & \updownarrow \\
\hline \rceil & 1 backslash & \Uparrow & $\Uparrow$ & \Updownarrow \\
\hline
\end{tabular}
boly:

Pokud v display módu chceme použít složené zlomky, pak bychom měli zapsat běžným způsobem pouze ten vnější a pro ostatní by se měla zvolit forma a/b. Pro vysázení:

$$
a_{0}+\frac{a}{a_{1}+\frac{1}{a_{2}}}
$$

bychom neměli psát $\$ \$ a_{-} 0+\left\{\backslash\right.$ frac $\{a\}\left\{a_{-} 1+\backslash\right.$ frac $\left.\left.\{1\}\left\{a_{-} 2\right\}\right\}\right\} \$$ ale spíše $\$ \$ a_{-} 0+$ $\left\{\backslash f r a c\{a\}\left\{a \_1+1 / a_{-} 2\right\}\right\} \$ \$$, abychom dostali přehlednější

$$
a_{0}+\frac{a}{a_{1}+1 / a_{2}}
$$

Mimoto lze použít př́kaz \displaystyle. Pokud zapíšeme $\$ \$ a_{-} 0+\left\{\backslash f r a c\{a\}\left\{a_{-} 1+\right.\right.$ $\backslash$ frac $\{1\}\{\backslash$ strut \displaystyle a_2\}\}\}\$ , tak dostaneme:

$$
a_{0}+\frac{a}{a_{1}+\frac{1}{a_{2}}}
$$

Níže ukážeme použití př́íkazů \matrix, \pmatrix, \ldots, \cdots a \cases bez dalšího vysvětlování. 
$\$ \$$

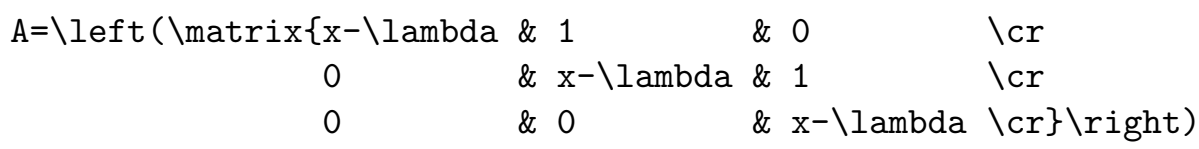

$\$ \$$

$$
A=\left(\begin{array}{ccc}
x-\lambda & 1 & 0 \\
0 & x-\lambda & 1 \\
0 & 0 & x-\lambda
\end{array}\right)
$$
$A=\backslash$ left $\mid \backslash$ matrix $\{x-\backslash$ mu\& $1 \quad \& \quad 0 \quad \backslash c r$
$0 \quad \& \mathrm{x}-\backslash \mathrm{mu} \& 1 \quad \backslash \mathrm{cr}$
$0 \quad \& 0 \quad \& \quad x-\backslash m u \backslash$ cr $\} \backslash$ right $\mid$

$\$ \$$

$$
A=\left|\begin{array}{ccc}
x-\mu & 1 & 0 \\
0 & x-\mu & 1 \\
0 & 0 & x-\mu
\end{array}\right|
$$

$\$ \$$

$A=\backslash$ pmatrix $\left\{a_{-}\{11\} \& a_{-}\{12\} \& \backslash \backslash\right.$ dots \& $a_{-}\{1 n\} \backslash c r$ $a_{-}\{21\} \& a_{-}\{22\} \& \backslash \operatorname{ldots} \& a_{-}\{2 n\} \backslash c r$

\vdots \& \vdots \& \ddots \& \vdots $\backslash \mathrm{cr}$

$\left.a_{-}\{m 1\} \& a_{-}\{m 2\} \& \backslash 1 \operatorname{dots} \& a_{-}\{m n\} \backslash c r\right\}$

$\$ \$$

$$
A=\left(\begin{array}{cccc}
a_{11} & a_{12} & \ldots & a_{1 n} \\
a_{21} & a_{22} & \ldots & a_{2 n} \\
\vdots & \vdots & \ddots & \vdots \\
a_{m 1} & a_{m 2} & \ldots & a_{m n}
\end{array}\right)
$$

$\$ \$$

$|x|=\backslash$ cases $\{\backslash$ hphantom $\{-\} \mathrm{x}$, \& pokud $\$ \mathrm{x} \backslash$ geq0\$; $\backslash \mathrm{cr}$

$$
-x \text {, \& jinak. } \backslash c r\}
$$

$\$ \$$

$$
|x|=\left\{\begin{aligned}
x, & \text { pokud } x \geq 0 \\
-x, & \text { jinak. }
\end{aligned}\right.
$$

Pokud chceme vysázet v matematickém výrazu běžný text, musíme uvážit dvě věci. Za prvé, mezera se v matematickém módu se nevysází běžným způsobem a je třeba ji vynutit pomocí $\backslash$ (obráceného lomítka). Za druhé, je nutné změnit font, protože běžný text by se neměl sázet matematickou kurzivou, ale aktuálním fontem.

$$
x^{3}+\text { termy nižších řádů }
$$


Sazba matematiky

Matematické funkce jako sin a tan, které se musí vysázet aktuálním fontem, jsou v TEXu předdefinované:

$\begin{array}{llllllll}\text { larccos } & \backslash \text { cos } & \backslash \text { csc } & \backslash \text { exp } & \backslash \text { ker } & \backslash \text { limsup } & \backslash \text { min } & \backslash \text { sinh } \\ \text { larcsin } & \backslash \text { cosh } & \backslash \text { deg } & \backslash \text { gcd } & \backslash \text { lg } & \backslash \text { ln } & \backslash P r & \backslash \text { sup } \\ \text { larctan } & \backslash \text { cot } & \backslash \text { det } & \backslash \text { hom } & \backslash \text { lim } & \backslash \text { log } & \backslash \text { sec } & \text { tan } \\ \text { larg } & \backslash \text { coth } & \backslash \text { dim } & \backslash \text { inf } & \backslash \text { liminf } & \backslash \text { max } & \backslash \text { sin } & \text { tanh }\end{array}$

Pokud zapíšeme funkci sinus $\$ \$ \backslash$ sin $2 \backslash$ theta $=2 \backslash \sin \backslash$ theta $\backslash \cos \backslash$ theta $\$ \$$ nebo limitu $\$ \$ \backslash \lim _{-}\{\mathrm{x} \backslash$ to 0$\}\{\backslash$ frac $\{\backslash \sin \mathrm{x}\}\{\mathrm{x}\}\}=1 \$ \$$ dostaneme:

$$
\sin 2 \theta=2 \sin \theta \cos \theta \quad \text { nebo } \quad \lim _{x \rightarrow 0} \frac{\sin x}{x}=1
$$

Zarovnání v matematických výrazech si zaslouží zvláštní pozornost. Ve víceřádkových výrazech někdy potřebujeme zarovnání podle znaménka,$=^{\prime}$. To se dělá pomocí př́íkazu leqalign. Pokud zapíšeme:

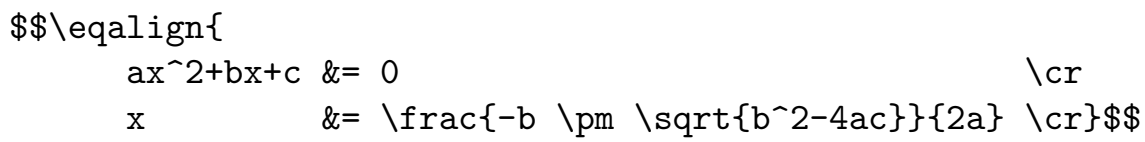

vysází se:

$$
\begin{aligned}
a x^{2}+b x+c & =0 \\
x & =\frac{-b \pm \sqrt{b^{2}-4 a c}}{2 a}
\end{aligned}
$$

Někdy je potřeba zarovnávat podle více různých míst. Jak lze tento požadavek uskutečnit, je vidět na druhém řádku následujícího př́ikladu:

\$\$eqalign \{

$$
\begin{array}{rlrlrl}
\mathrm{ax}+\mathrm{bx}+\backslash \mathrm{cdots}+\mathrm{yx}+\mathrm{zx} & \& & =\mathrm{x}(\mathrm{a}+\mathrm{b}+\backslash \mathrm{cdots} & & \backslash \mathrm{cr} \\
& \& \backslash \mathrm{phantom}\{=\mathrm{x}(\mathrm{a} \sim\}+\mathrm{y}+\mathrm{z}) & & \backslash \mathrm{cr} \\
& \& & =y & & \\
& & &
\end{array}
$$

Výsledkem pak je:

$$
\begin{aligned}
a x+b x+\cdots+y x+z x & =x(a+b+\cdots \\
& +y+z) \\
& =y
\end{aligned}
$$

Vedle př́kazu \phantom je zde ještě \hphantom bez výšky a hloubky a \vphantom bez šířky.

Na velikosti mezer $v$ matematickém výrazu se většinou můžeme na $T_{E} X$ plně spolehnout. Nicméně v některých situacích se nám může hodit jejich velikost ovlivňovat. To se dělá pomocí:

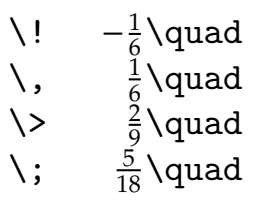

Velikost těchto ,mezer' je určena relativně k mezeře, kterou lze vyvolat př́kazem \quad a která má šířku velkého písmene , $\mathrm{M}^{\prime}$. 
Užití příkazu \prime ${ }^{3}$ hovoří sama za sebe. Pokud bychom např́klad chtěli vysázet $y_{1}^{\prime}+y_{2}^{\prime \prime}$, měli bychom zapsat $\$ y_{-} 1 \smile \backslash$ prime+y_2 $2 \backslash$ prime $\backslash$ prime $\$$.

Výraz jako $\sqrt[3]{x^{2}+y^{2}}$ lze získat pomocí zápisu \$root 3 \of $\left\{\mathrm{x}^{\wedge} 2+\mathrm{y}^{\wedge} 2\right\} \$$.

Na konci této sekce si ukážeme použití př́kazu \mathstrut, kterým můžeme dosáhnout vyrovnání velikostí, např́íklad symbolů odmocnin. Pomocí $\$ \backslash$ sqrt $\{\backslash$ mathstrut a $\}+\backslash$ sqrt $\{\backslash$ mathstrut $\mathrm{d}\}+\backslash$ sqrt $\{\backslash$ mathstrut $\mathrm{y}\} \$$ dostaneme $\sqrt{a}+\sqrt{d}+\sqrt{y}$. Bez př́kazu \mathstrut bychom dostali $\sqrt{a}+\sqrt{d}+\sqrt{y}$.

\subsection{Umístění matematických formulí}

Jednotlivé matematické vzorce můžeme číslovat pomocí:

$\backslash$ placeformula $[\ldots, \ldots]\{.2\} \$ \.$ . \stackrel{3}{.} \$ \$$ OPTIONAL OPTIONAL

1 REFERENCE

2 TEXT

\section{\startformula ... \stopformula}

Dva př́klady:

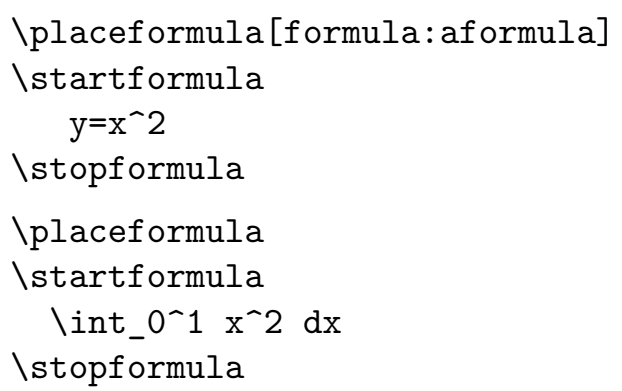

$$
\begin{gathered}
y=x^{2} \\
\int_{0}^{1} x^{2} d x
\end{gathered}
$$

CONTEXTové př́íkazy \startformula $\cdots$ \stopf ormula nahrazují počáteční a koncové \$\$. Když totiž napíšeme:

\section{$\$ \$$}

$\backslash$ int_0^1 $\mathrm{x}^{\wedge} 2 \mathrm{dx}$

\section{$\$ \$$}

3 ,prime' je anglický výraz pro čárku v indexu. Pozn. překl. 
dostaneme výraz, který je sice zobrazen ve středu stránky, ale není tak dobře zarovnán jako v předcházejících př́íkladech.

$$
\int_{0}^{1} x^{2} d x
$$

Příkaz \placeformula zajistí mezeru okolo matematického vzorce a také její označení číslem. Hranaté závorky nejsou povinné a slouží pro uvedení referenčního jména pro odkazy, a také pro zapnutí a vypnutí číslování.

$$
\begin{aligned}
& y=x^{2} \\
& y=x^{3} \\
& y=x^{4}
\end{aligned}
$$

Rovnice 7.4 byla vysázena takto:

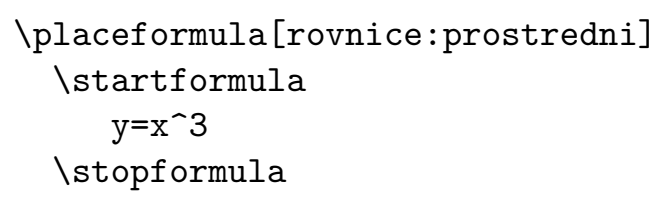

Nápis v hranaté závorce [rovnice: prostredni] slouží pro odvolání se na tuto rovnici v textu. Tuto referenci jsme provedli př́kazem \in\{Rovnice\} [rovnice:prostredni].

Jestliže nevyžadujeme číslování, zapíšeme:

$\backslash$ placeformula [-]

Číslování rovnic se nastavuje pomocí \setupnumbering. V tomto manuálu je číslování nastaveno př́kazem \setupnumbering [way=bychapter]. To znamená, že před číslem rovnice je uvedeno číslo kapitoly a v každé další kapitole je číslování opět vynulováno. Pro zachování jednotnosti jsou tabulky, obrázky apod. číslovány stejným způsobem. Proto se \setupnumbering používá v deklarační oblasti vstupního souboru.

Rovnice mohou být nastaveny pomocí př́kazu: 
\setupformulae $[\ldots, . * *, .$.

* location

$=$ left right

left

$=$ TEXT

right $=$ TEXT

align = inner outer left right middle normal no yes

option $=$ middle

strut $=$ yes no

distance $=$ DIMENSION

margin $=$ DIMENSION

leftmargin $=$ DIMENSION

standard yes no

rightmargin $=$ DIMENSION

indentnext $=$ yes no

alternative $=$ IDENTIFIER

spacebefore $=$ DIMENSION

after $\quad=$ DIMENSION

separator $=$ TEXT

conversion $=$ numbers characters Characters romannumerals Romannumerals TEXT

\section{Příkazy v matematickém módu}

8.1 ̌̌necká abeceda

\begin{tabular}{|c|c|c|c|c|c|c|c|}
\hline & \alpha & & l & \iota & & $\varrho$ & \varrho \\
\hline & Ibeta & & $\kappa$ & \kappa & $\Sigma$ & $\sigma$ & $\backslash$ sigma \\
\hline$\Gamma$ & Igamma & $\Lambda$ & $\lambda$ & $\backslash$ lambda & & $\varsigma$ & \varsigma \\
\hline \multirow[t]{5}{*}{$\Delta$} & Idelta & & $\mu$ & $\backslash \mathrm{mu}$ & & $\tau$ & $\backslash$ tau \\
\hline & \epsilon & & $v$ & $\backslash \mathrm{nu}$ & & $v$ & \upsilon \\
\hline & \varepsilon & $\Xi$ & $\xi$ & $\backslash x i$ & $\Phi$ & $\phi$ & $\backslash \mathrm{phi}$ \\
\hline & $\backslash$ zeta & & $o$ & o & & $\varphi$ & \varphi \\
\hline & leta & $\Pi$ & $\pi$ & $\backslash p i$ & & $\chi$ & $\backslash$ chi \\
\hline \multirow[t]{2}{*}{$\Theta$} & \theta & & $\omega$ & \varpi & $\Psi$ & $\psi$ & $\backslash p s i$ \\
\hline & $\vartheta$ Ivartheta & & $\rho$ & \rho & $\Omega$ & $\omega$ & \omega \\
\hline
\end{tabular}

\subsection{Zvláštní symboly}

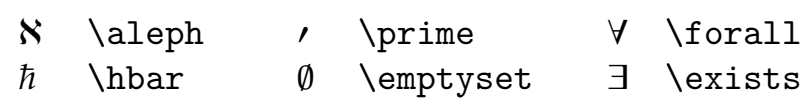


Příkazy v matematickém módu

\begin{tabular}{|c|c|c|c|c|}
\hline \imath & $\nabla$ & \nabla & $\neg$ & $\backslash$ neg \\
\hline \jmath & $\sqrt{ }$ & $\backslash$ surd & b & $\backslash$ flat \\
\hline$\backslash \mathrm{ell}$ & $\mathrm{T}$ & $\backslash$ top & ฤ & $\backslash$ natural \\
\hline \wp & $\perp$ & $\backslash$ bot & $\sharp$ & $\backslash$ sharp \\
\hline$\backslash$ Re & $\|$ & \Vert & \& & \clubsuit \\
\hline$\backslash \operatorname{Im}$ & $\angle$ & \angle & $\diamond$ & \diamondsuit \\
\hline \partial & $\triangle$ & \triangle & $\varnothing$ & \heartsuit \\
\hline \infty & 1 & \backslash & ه & \spadesuit \\
\hline
\end{tabular}

88.3 Operátory doplňující,$+-\mathrm{a}$ *

\begin{tabular}{|c|c|c|c|c|}
\hline$\pm \quad \backslash p m$ & $\cap$ & $\backslash$ cap & V & \vee \\
\hline$\backslash \mathrm{mp}$ & $U$ & $\backslash$ cup & $\wedge$ & \wedge \\
\hline$\backslash$ setminus & $\uplus$ & \uplus & $\oplus$ & \oplus \\
\hline$\backslash c \operatorname{dot}$ & $\sqcap$ & \sqcap & $\ominus$ & lominus \\
\hline$\backslash$ times & $\sqcup$ & \sqcup & $\otimes$ & lotimes \\
\hline last & $\triangleleft$ & \triangleleft & $\oslash$ & \oslash \\
\hline Istar & $\triangleright$ & \triangleright & $\odot$ & lodot \\
\hline \diamond & 2 & $\backslash w r$ & 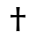 & \dagger \\
\hline$\backslash$ circ & $\bigcirc$ & \bigcirc & $\ddagger$ & \ddagger \\
\hline - \bullet & $\triangle$ & \bigtriangleup & $\amalg$ & \amalg \\
\hline \div & $\nabla$ & \bigtriangledown & & \\
\hline
\end{tabular}

\subsection{Operátory}

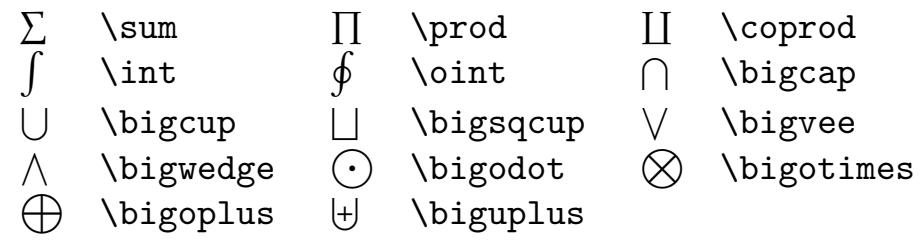

8.5 Relace doplňující $>,<\mathrm{a}=$

\begin{tabular}{|c|c|c|c|c|}
\hline$\backslash$ leq & $\geq$ & Igeq & $\equiv$ & \equiv \\
\hline Iprec & $>$ & $\backslash$ succ & $\sim$ & $\backslash$ sim \\
\hline$\backslash$ preceq & $\geq$ & $\backslash$ succeq & $\simeq$ & \simeq \\
\hline$\backslash 11$ & $\gg$ & $\operatorname{lgg}$ & $\asymp$ & \asymp \\
\hline$\backslash$ subset & $\supset$ & \supset & $\approx$ & \approx \\
\hline$\backslash$ subseteq & $\supseteq$ & \supseteq & $\cong$ & \cong \\
\hline \sqsubseteq & $\sqsupseteq$ & \sqsupseteq & $\bowtie$ & \bowtie \\
\hline \in & $\ni$ & $\backslash n i$ & $\propto$ & $\backslash$ propto \\
\hline \vdash & $\dashv$ & $\backslash$ dashv & $\vDash$ & $\backslash$ models \\
\hline$\backslash$ smile & | & $\backslash \mathrm{mid}$ & $\doteq$ & \doteq \\
\hline$\backslash$ frown & $\|$ & Iparallel & $\perp$ & $\backslash$ perp \\
\hline
\end{tabular}


8.6 Negované relace

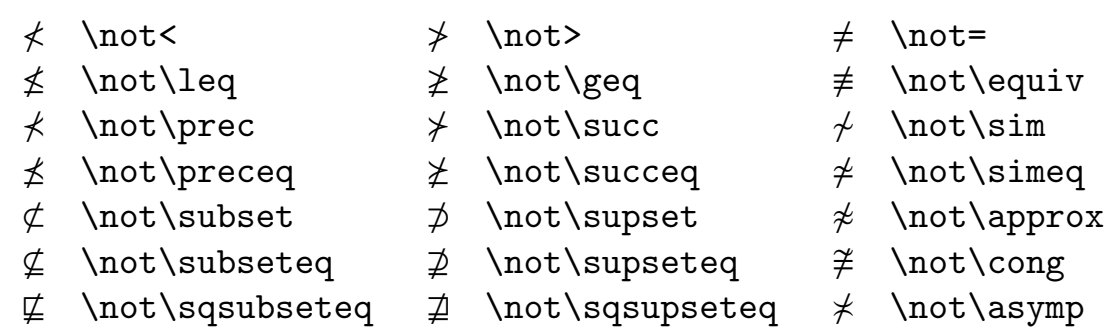

\section{7 Šipky}

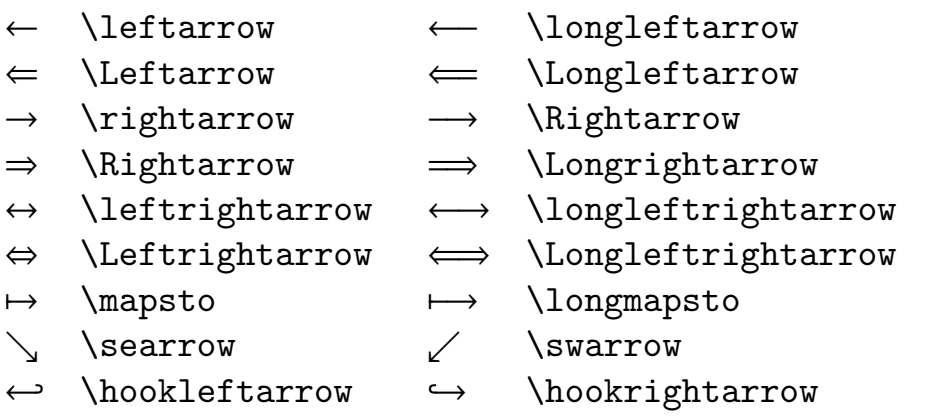

$\begin{array}{ll}\uparrow & \text { \uparrow } \\ \Uparrow & \text { \Uparrow } \\ \downarrow & \text { \downarrow } \\ \Downarrow & \text { \Downarrow } \\ \downarrow & \text { \updownarrow } \\ \Uparrow & \text { \Updownarrow } \\ \nearrow & \text { \nearrow } \\ \nwarrow & \text { \nwarrow }\end{array}$

\subsection{Alternativní příkazy}

$\begin{array}{llllllll}\neq & \backslash \text { ne } & \{ & \{ & \wedge & \backslash \text { land } & \rightarrow \text { mediummedium } & \text { |vert } \\ \leq & \text { le } & \} & \} & \vee \backslash \text { lor } & \leftarrow \text { Igets } \\ \geq & \text { Ige } & \ni & \text { lowns } & \neg \backslash \text { lnot } & & & \end{array}$

Abychom se přiměli používat míry a jednotky v celém dokumentu jednotně, můžeme vytvořit vlastní seznam těchto jednotek a umístit ho do deklarační oblasti (před př́kaz \starttext) vstupního souboru.

V CONTEXTu je dostupný vnější modul, který obsahuje téměř všechny jednotky SI. Pokud se na tento modul odvoláme př́kazem \usemodule [units], můžeme pak používat jednotky následujícím způsobem: 


\section{Obrázky}

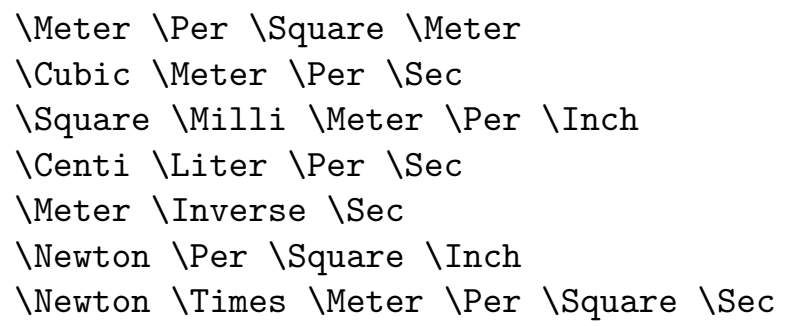

Trocha více psaní je vyvážena zárukou jednotného přístupu v užívání jednotek. Příkaz \unit také zaručuje, že od sebe nebudou odděleny hodnota a její jednotka. Pokud se totiž hodnota nachází na konci řádku a následující řádek začíná měrnou jednotkou, má to k dokonalosti daleko. Náš

10 předchozí prríklad se vysází takto:
$\mathrm{m} / \mathrm{m}^{2}$
$\mathrm{m}^{3} / \mathrm{s}$
$\mathrm{mm}^{2} /$ inch
$\mathrm{cl} / \mathrm{s}$
$\mathrm{ms}^{-1}$
$\mathrm{N} /$ inch $^{2}$
$\mathrm{N} \cdot \mathrm{m} / \mathrm{s}^{2}$

Můžeme také nadefinovat své vlastní jednotky:

Junit [Ounce] $\{o z\}\{\}$

Později ve svém dokumentu můžeme napsat 15.6 \Ounce, což bude vysázeno jako 15.6 oz.

Pro zapsání \% a \% jednotným způsobem slouží dva zvláštní příkazy:

$\backslash$ percent

$\backslash$ permille

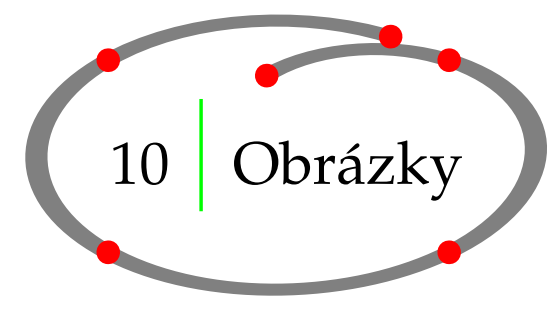

Obrázky a fotografie vložíme do dokumentu následujícím příkazem:

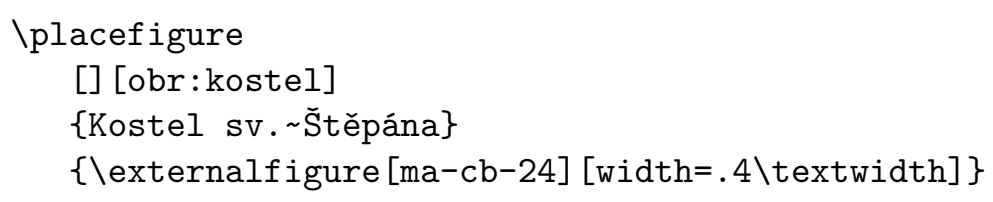

Po zpracování se na první dostupné místo vysází obrázek 10.1 


\section{Obrázky}

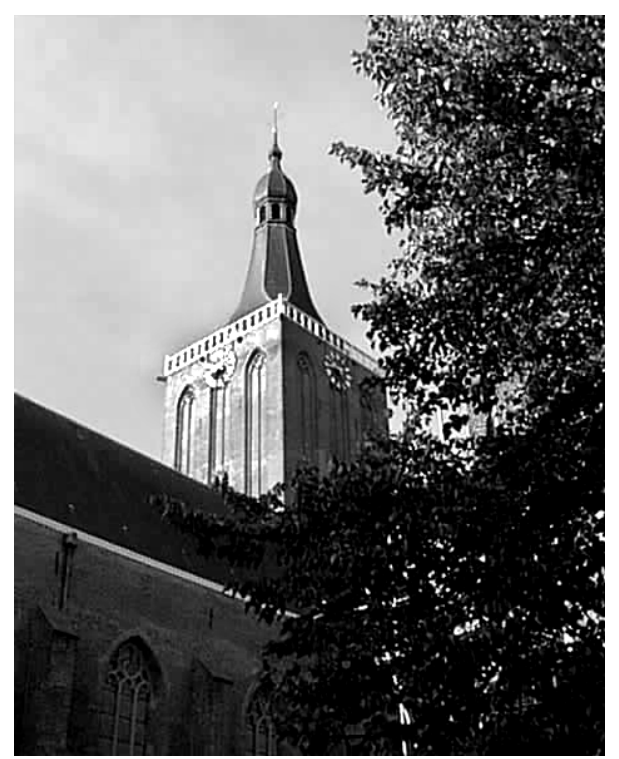

Obrázek 10.1 Kostel sv. Štěpána

Příkaz \placefigure se postará o číslování a vertikální odsazení obrázku. Dále tento př́ikaz inicializuje mechanismus umístění plovoucích objektů, což znamená, že se CONTEXT podívá, zda je na dané stránce pro náš obrázek dostatek místa. Pokud není, bude obrázek umístěn na jiné vhodné místo. $V$ takovém případě bude text pokračovat a obrázek bude proplouvat naším dokumentem, dokud pro něj nebude nalezeno optimální umístění. Tento mechanismus můžeme ovlivňit parametrem v první dvojicí závorek.

Př́kaz \placefigure je předdefinovanou instancí:

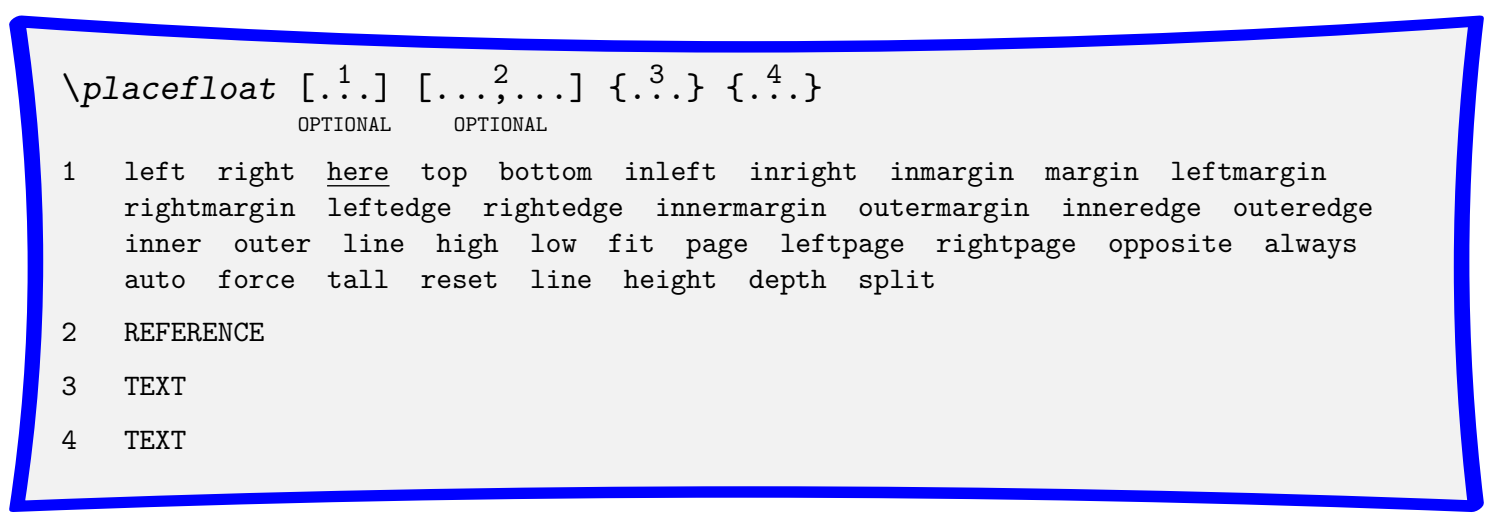

Zde použitelné parametry jsou popsané v tabulce 10.1.

Druhý pár hranatých závorek je určen pro referenční jméno odkazu. Na konkrétní obrázek se můžete odkázat př́kazem:

\section{\in\{obrázek\} [obr:kostel]}

První pár složených závorek tohoto př́kazu obsahuje popisek obrázku. Můžeme tam napsat libovolný text. Pokud si nepřejeme žádný popisek, ani číslování, můžeme použít \{none\}. Popisek je formátován pomocí \setupcaptions a nastavení (případně vynulování) číslování se řídí prúíkazem \setupnumbering (viz sekce 37.2). 
Obrázky

\begin{tabular}{ll}
\hline Parametr & Vysvětlení \\
\hline $\begin{array}{l}\text { here } \\
\text { force }\end{array}$ & pokud je to možné, umísti obrázek na toto místo \\
page & umúst umístění obrázku na tomto místě \\
top & umísti obrázek k hornímu okraji stránky \\
bottom & umísti obrázek k dolnímu okraji stránky \\
left & umísti obrázek k levému okraji \\
right & umísti obrázek k pravému okraji \\
margin & umísti obrázek do marginálie \\
\hline
\end{tabular}

Tabulka 10.1 Parametry v př́kazu \placefigure.

Druhý pár závorek je pro vložení vlastního obrázku. Nejčastěji zde uvádíme př́kaz pro vložení externího souboru \externalf igure, viz níže.

V následujícím př́kladu vidíme použití funkce $\backslash p l a c e f$ igure\{\}\{\}. V̌̌imněme si obsahu druhé závorky, nutné pro vysázení Hasselt.

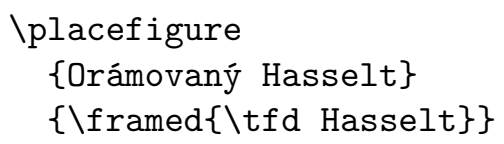

Tento př́klad vysází:

\section{Hasselt}

Obrázek 10.2

Orámovaný Hasselt

Obrázky nicméně často vytváříme v programech jako Corel Draw nebo Illustrator. Fotky - po oskenování - se obvykle upraví v GIMPu nebo PhotoShopu. Po této práci máme obrázky ve formě souborů. CONTEXT podporuje všechny formáty souborů, se kterými umí nakládat ovladač v pozadí CONTEXTu. Pokud používáme PDFTEX, můžeme vkládat JPG, PNG a jednotlivé stránky ze souborů PDF jakož i výstup METAPOSTu, (soubory typu MPS). Uživatelé obvykle mohou CONTEXTu důvěřovat, že nalezne nejlepší možný formát souboru.

Na obrázku 10.3 vidíme fotografii a vektorovou grafiku kombinovanou do jednoho obrázku.

Tento obrázek můžeme vysázet pomocí kódu podobného tomuto:

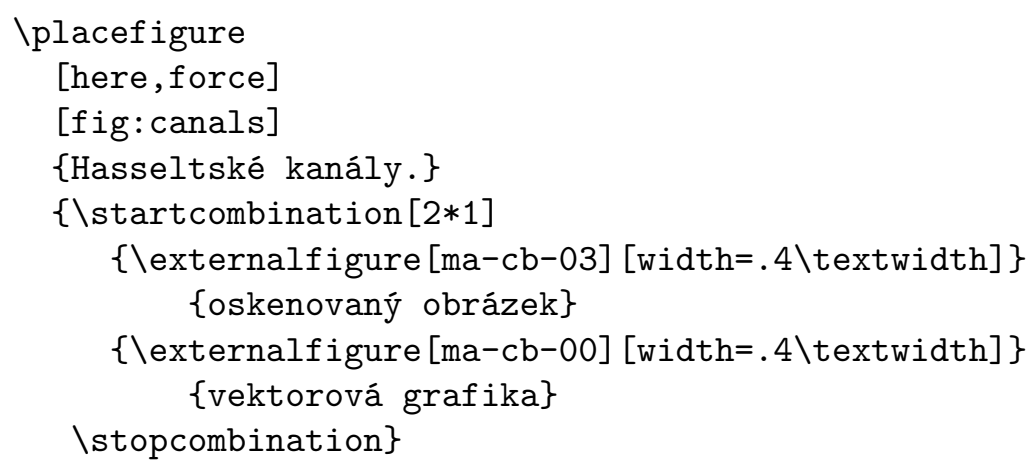




\section{Obrázky}

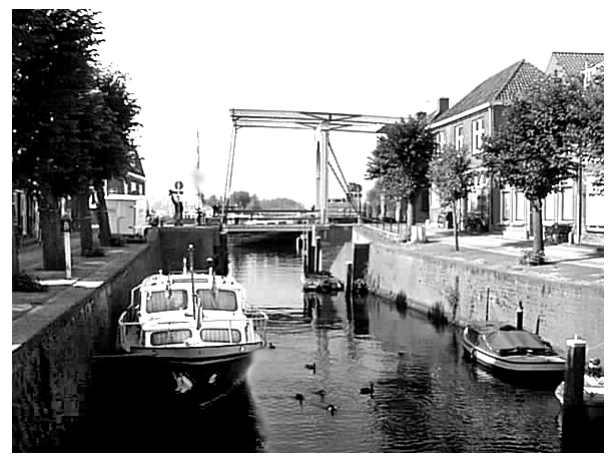

oskenovaný obrázek

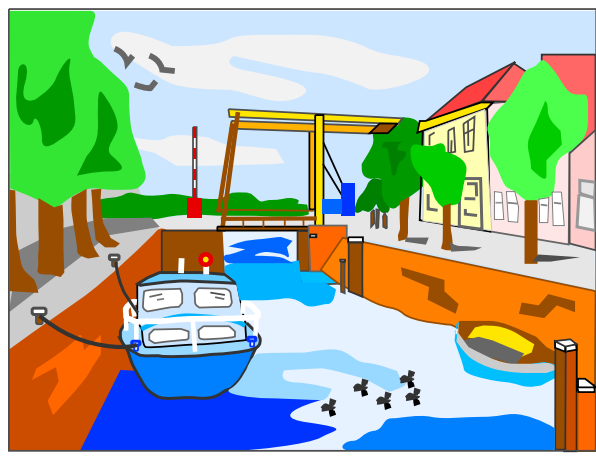

vektorová grafika

Obrázek 10.3 Hasseltské kanály.

V tomto jednom plovoucím objektu jsou dva obrázky kombinovány pomocí:

\startcombination $[. *$... . Istopcombination

$* \quad \mathrm{~N} * \mathrm{M}$

Dvojice př́kazů \startcombination ... \stopcombination je užívána pro kombinaci dvou obrázků do jednoho plovoucího objektu. Pomocí hranatých závorek můžeme ovlivnit vysázení většího množství obrázků. Jeden obrázek pod druhým se vysází pomocí [1*2]. Můžeme si představit, co se stane, když zkombinujeme 6 obrázků pomocí [3*2] ([řádky*sloupce]).

Uvedené př́klady jsou dostačující pro vytváření ilustrovaných dokumentů. Nicméně někdy je potřeba více ovlivnit uspořádání obrázku a textu. Pro tento účel můžete použít:

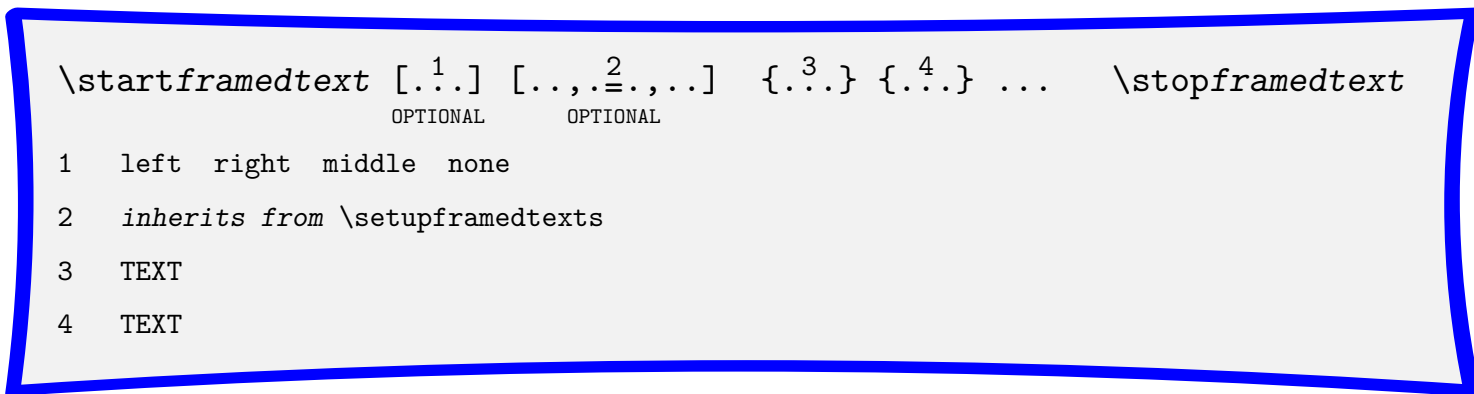

Místo slova framed můžeme použít dříve definovaný rámovaný objekt. Obrázek (figure) a tabulka (table) jsou již předdefinované, jak je vidět z následujícího př́kladu kombinujícího obrázek $\mathrm{s}$ textem.

\footnotetext{
\startfiguretext

[left]

[fig:citizens]

\{none\}

$\{\backslash$ externalfigure [ma-cb-18] [width=.5\makeupwidth]

Počet obyvatel Hasseltu se odjakživa měnil v závislosti

na ekonomických podmínkách. Příkladem může být kopání
} 


\section{Obrázky}

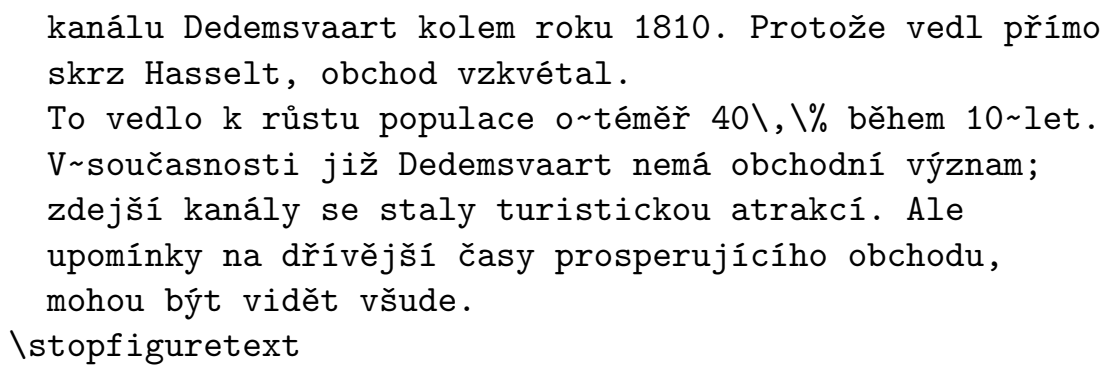

Po vysázení uvidíme:

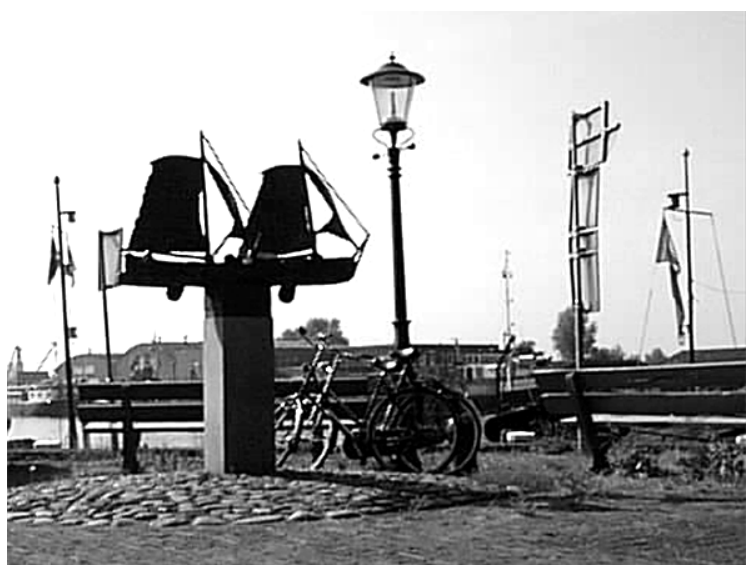

Počet obyvatel Hasseltu se odjakživa měnil v závislosti na ekonomických podmínkách. Př́íladem může být kopání kanálu Dedemsvaart kolem roku 1810. Protože vedl přímo skrz Hasselt, obchod vzkvétal. To vedlo k růstu populace o téměř $40 \%$ během 10 let. V současnosti již Dedemsvaart nemá obchodní význam; zdejší kanály se staly turistickou atrakcí. Ale upomínky na dřívější časy prosperujícího obchodu, mohou být vidět všude.

Poslední pár složených závorek většinou obsahuje příkaz \externalf igure.

\externalfigure $[. .1].[\ldots, . \stackrel{2}{=} .,$.

1 FILE

2 inherits from \useexternalfigure

Tento př́kaz nám dává svobodu vysázet obrázek jakýmkoliv způsobem si budeme přát. lexternalf igure obsahuje dva páry hranatých závorek. První se užívá pro přesný název souboru bez př́ípony, druhý pro požadované rozměry a ev. formát souboru. Není obtížné si představit co způsobí vysázení zdrojového textu: ${ }^{4}$

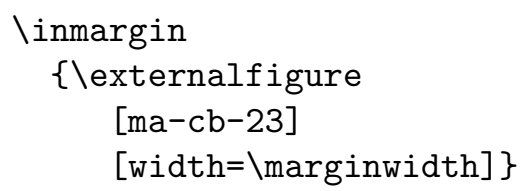

Umístění a rozměry obrázku můžeme ovlivnit pomocí:

${ }^{4}$ Viz stranu 61. 


\section{Obrázky}

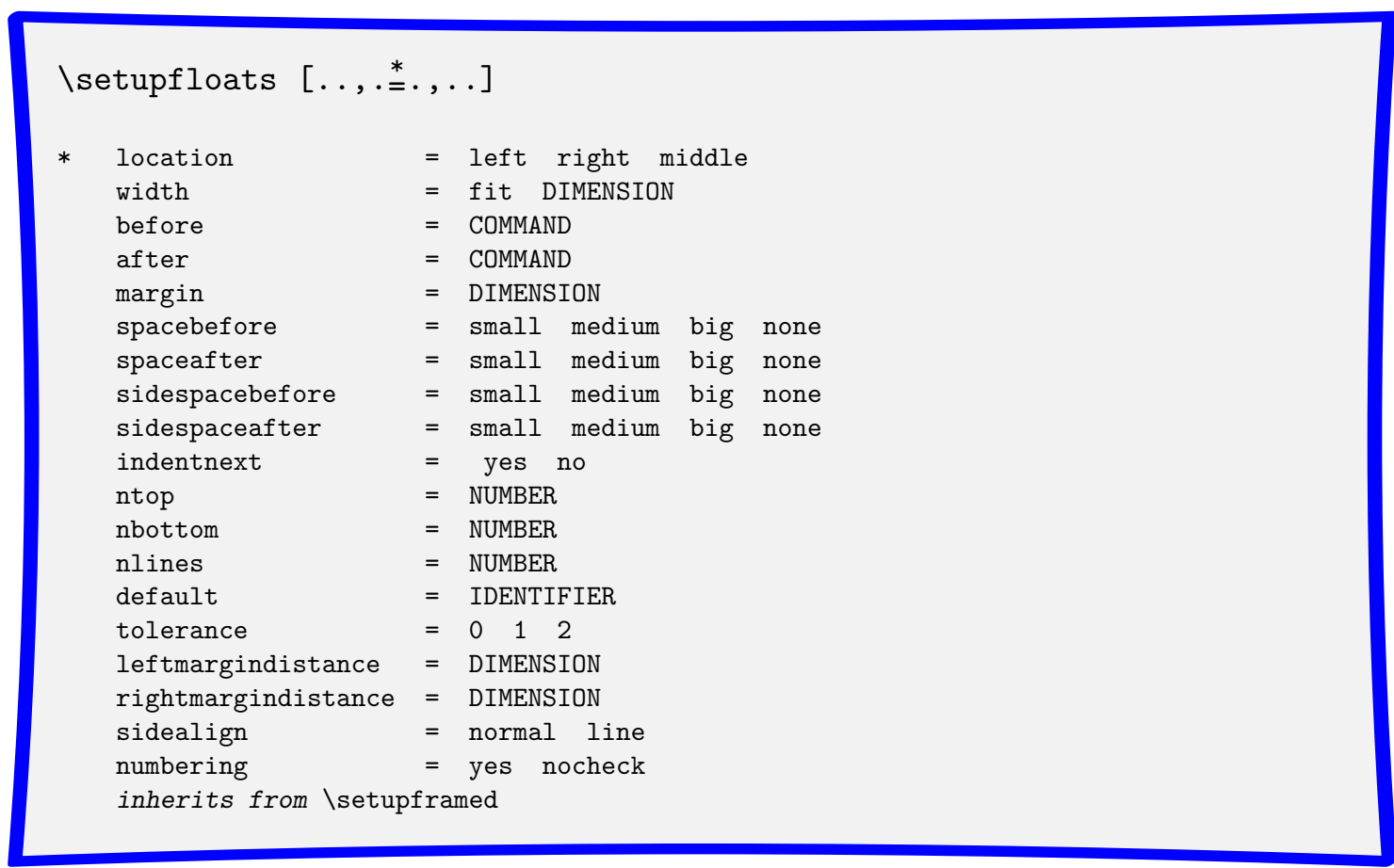

Můžeme také nastavit číslování obrázků a jejich popisek:

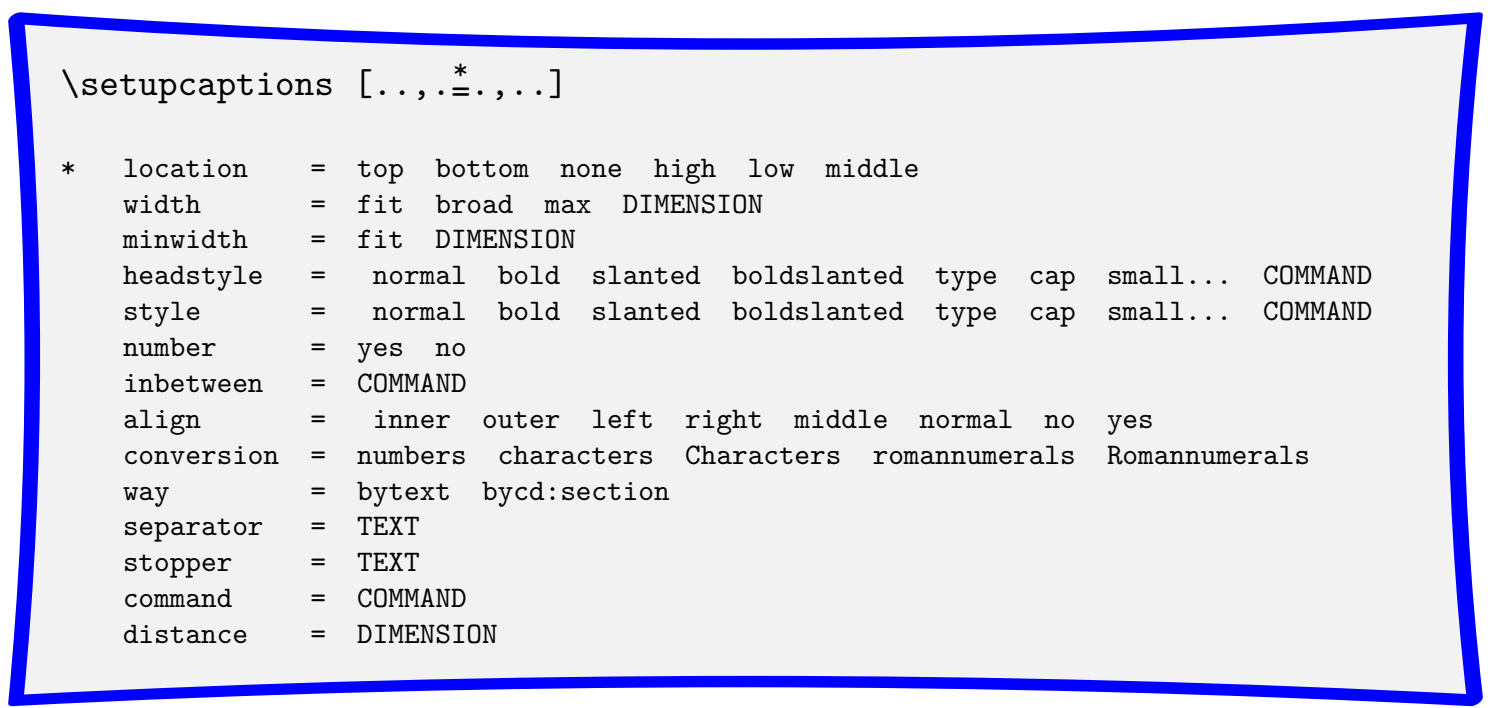

Následující př́kazy patří do deklarační oblasti vstupního souboru a mají tedy vliv na všechny plovoucí objekty.

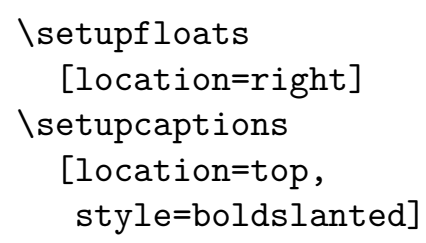


Tabulky

$\backslash$ placefigure

\{Typický obrázek Hasseltu.\}

$\{\backslash$ externalfigure $[\mathrm{ma}-\mathrm{cb}-12][$ width $=8 \mathrm{~cm}]\}$

Obrázek 10.4 Typický obrázek Hasseltu.

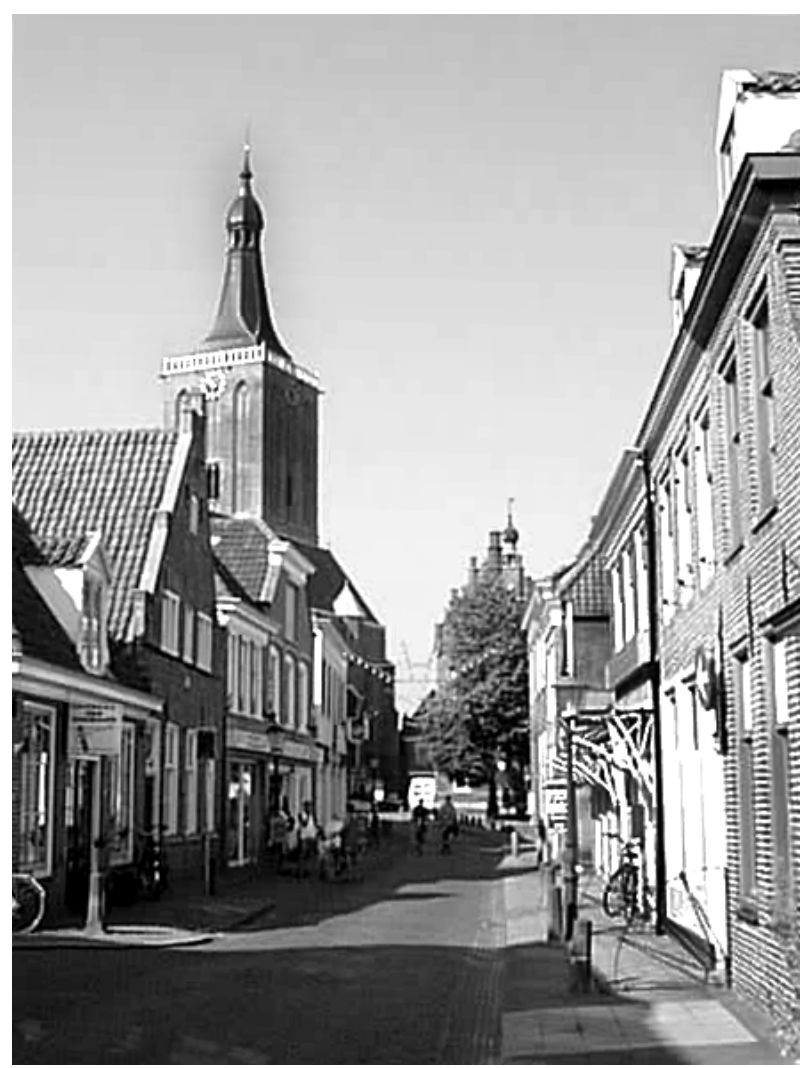

11

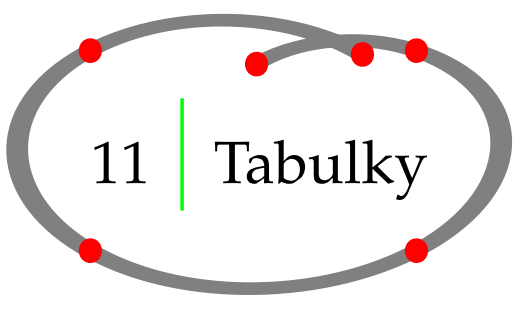

Tabulka se obecně skládá ze sloupců. Jejich obsah může být zarovnán vlevo, vpravo, na střed či $k$ desetinné čárce. Záhlaví může zaujímat jeden nebo více sloupců. Buňky tabulky mohou obsahovat rovnice nebo několik řádků textu. Horizontální a vertikální linky mohou vést přes celou tabulku nebo jen přes její část.

Toto napsal J. Wichura v předmluvě manuálu o $\mathrm{T}_{\mathrm{A}} \mathrm{B}_{\mathrm{L}} \mathrm{E}\left(\mathrm{T}_{\mathrm{A}} \mathrm{B}_{\mathrm{L}} \mathrm{E}\right.$ manual, 1988). Michael Wichura je také autorem jedné ze sady maker $\mathrm{T}_{\mathrm{A}} \mathrm{B}_{\mathrm{L}} \mathrm{E}$, kterou CONTE $\mathrm{CT}$ používá $\mathrm{k}$ sazbě tabulek. ${ }^{5}$ 


\section{Tabulky}

Do definic $T_{A} B_{L} E$ bylo oproti originálu přidáno několik maker zajišt' ujících konzistentnější raádkování a bylo zjednodušeno uživatelské rozhraní. ${ }^{6}$

Tabulku umístíme př́kazem \placetable. Definujeme ji pomocí

\starttable $[. *$....$\quad$ \stoptable

* TEXT IDENTIFIER

Definice tabulky může vypadat následovně:

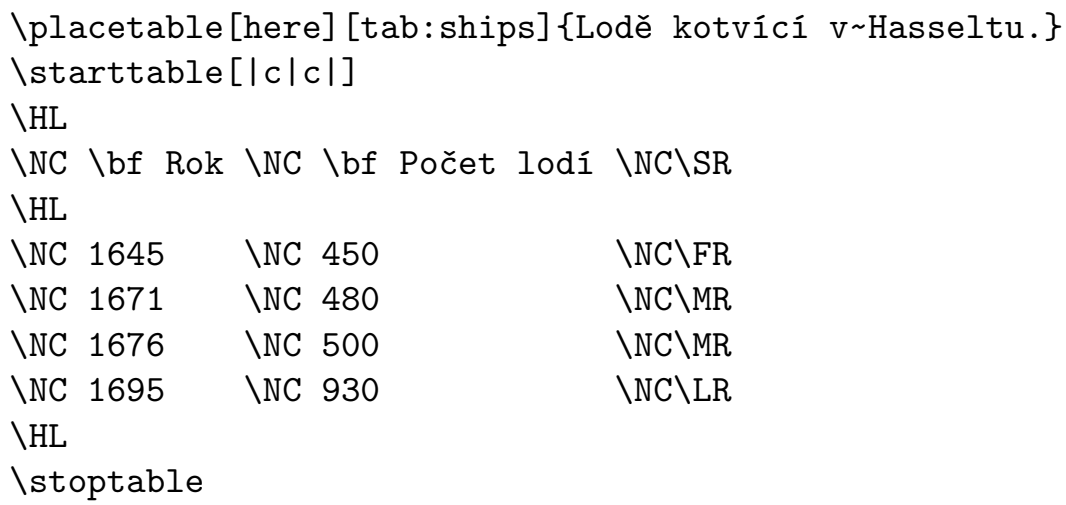

Tato tabulka je vysázena jako tabulka 11.1.

\begin{tabular}{cc}
\hline Rok & Počet lodí \\
\hline 1645 & 450 \\
1671 & 480 \\
1676 & 500 \\
1695 & 930 \\
\hline
\end{tabular}

Tabulka 11.1 Lodě

kotvící v Hasseltu.

První př́kaz \placetable má stejnou funkci jako \placefigure. Postará se o vertikální odsazení tabulky a o její číslo. Dále spustí mechanismus umístění plovoucího objektu a ten nalezne optimální polohu tabulky na stránce.

Položky tabulky se zadávají dovnitř dvojice \starttable ... \stoptable. Do hranatých závorek vkládáme značky pro formátování tabulky, viz tabulku 11.2.

5 CONTEXT nabízí ještě jiné sady. Velmi zajímavé jsou ,přirozené tabulky` \bTABLE. Umožňují podobnou syntaxi jako HTML tabulky s velkou variabilitou sdružování buněk a bohatými grafickými možnostmi. Řádkování je však méně přirozené. Viz manuál http://www.pragma-ade.com/general/manuals/enattab.pdf a magazín http://www.pragma-ade.com/general /myway/NaturalTables.pdf. Pozn. překl.

${ }^{6}$ CONTEXT byl vyvinut (také) pro uživatele bez technického nadání v éře WYSIwIG. Proto bylo doplněno přívětivé uživatelské rozhraní se snadnou manipulací se soubory a byly vypuštěny kryptické př́ikazy a programové i logické konstrukce. 
Tabulky

\begin{tabular}{ll}
\hline Značka & Význam \\
\hline I & oddělovač sloupců \\
$\mathrm{C}$ & sloupec se zarovnáním na střed \\
$\mathrm{I}$ & sloupec se zarovnáním vlevo \\
$\mathrm{r}$ & sloupec se zarovnáním vpravo \\
$\mathrm{S}<\mathrm{n}>$ & mezisloupcová mezera o hodnotě $n=0,1,2$ \\
w $<$ rozměr $>$ & minimální šîŕka sloupce o dané hodnotě \\
\hline
\end{tabular}

Tabulka 11.2 Značky pro formátování tabulky.

Jak jsme již viděli, existují kromě formátovacích značek ještě formátovací příkazy. Vkládají se př́mo do jednotlivých buněk. Ty základní ukazuje tabulka 11.3.

\begin{tabular}{|c|c|c|}
\hline Příkaz & & Význam \\
\hline$\backslash N R$ & další řádka & udělěj řádku bez vertikálního vyrovnání \\
\hline$\backslash F R$ & první řádka & udělěj řádku s horním vyrovnáním \\
\hline$\backslash \mathrm{LR}$ & poslední řádka & udělej řádku s dolním vyrovnáním \\
\hline$\backslash \mathrm{MR}$ & prostřední řádka & udělej řádku s horním i dolním vyrovnáním \\
\hline$\backslash \mathrm{SR}$ & oddělovací řádka & udělej řádku s horním i dolním vyrovnáním \\
\hline$\backslash V L$ & svislá linka & nakresli svislou linku a jdi na další sloupec \\
\hline$\backslash N \mathrm{NC}$ & další sloupec & jsi na další sloupec \\
\hline$\backslash \mathrm{HL}$ & vodorovná linka & nakresli vodorovnou linku \\
\hline$\backslash \mathrm{DL}$ & oddělovací linka ${ }^{\star}$ & nakresli linku přes následující sloupec \\
\hline$\backslash \mathrm{DL}[\mathrm{n}]$ & oddělovací linka & nakresli odělovací linku přes $n$ sloupců \\
\hline$\backslash \mathrm{DC}$ & oddělovací linka & udělej mezeru přes následující sloupec \\
\hline$\backslash \mathrm{DR}$ & oddělovací řádka ${ }^{\star}$ & udělej řádku s horním i dolním vyrovnáním \\
\hline$\backslash$ LOW $\{$ text $\}$ & - & napiš text níže \\
\hline$\backslash$ TWO, \THREE etc. & - & udělej mezeru přes $d v a$, tři,$\ldots$ sloupce \\
\hline
\end{tabular}

Př́kazy * \DL, \DC a \DR lze kombinovat.

Tabulka 11.3 Př́kazy pro formátování tabulky.

V dalších příkladech uvidíme formátovací příkazy CONTEXTu. Jejich jména jsou delší a méně kryptická a řídí další formátovací funkce tabulek. V tabulce 11.4 je jejich přehled.

\begin{tabular}{ll}
\hline Př́kaz & Význam \\
\hline$\backslash$ JustLeft & zarovnej vlevo a ignoruj formátování sloupce \\
$\backslash$ JustRight & zarovnej vpravo a ignoruj formátování sloupce \\
$\backslash$ JustCenter & vycentruj a ignoruj formátování sloupce \\
$\backslash$ SetTableToWidth\{\} & nastav pevnou šířku tabulky \\
$\backslash$ use\{n\} & přeskoč př́rš́ích $n$ sloupců \\
\hline
\end{tabular}

Tabulka 11.4 CONTEXTové formátovací př́kazy tabulky.

Tabulky ukázané dále jsou uvedené se zdrojovými texty. Pro složitější ukázky si lze také přečíst $\mathrm{T}_{\mathrm{A}} \mathrm{B}_{\mathrm{L}} \mathrm{E}$ manuál M. J. Wichury. 
Tabulky

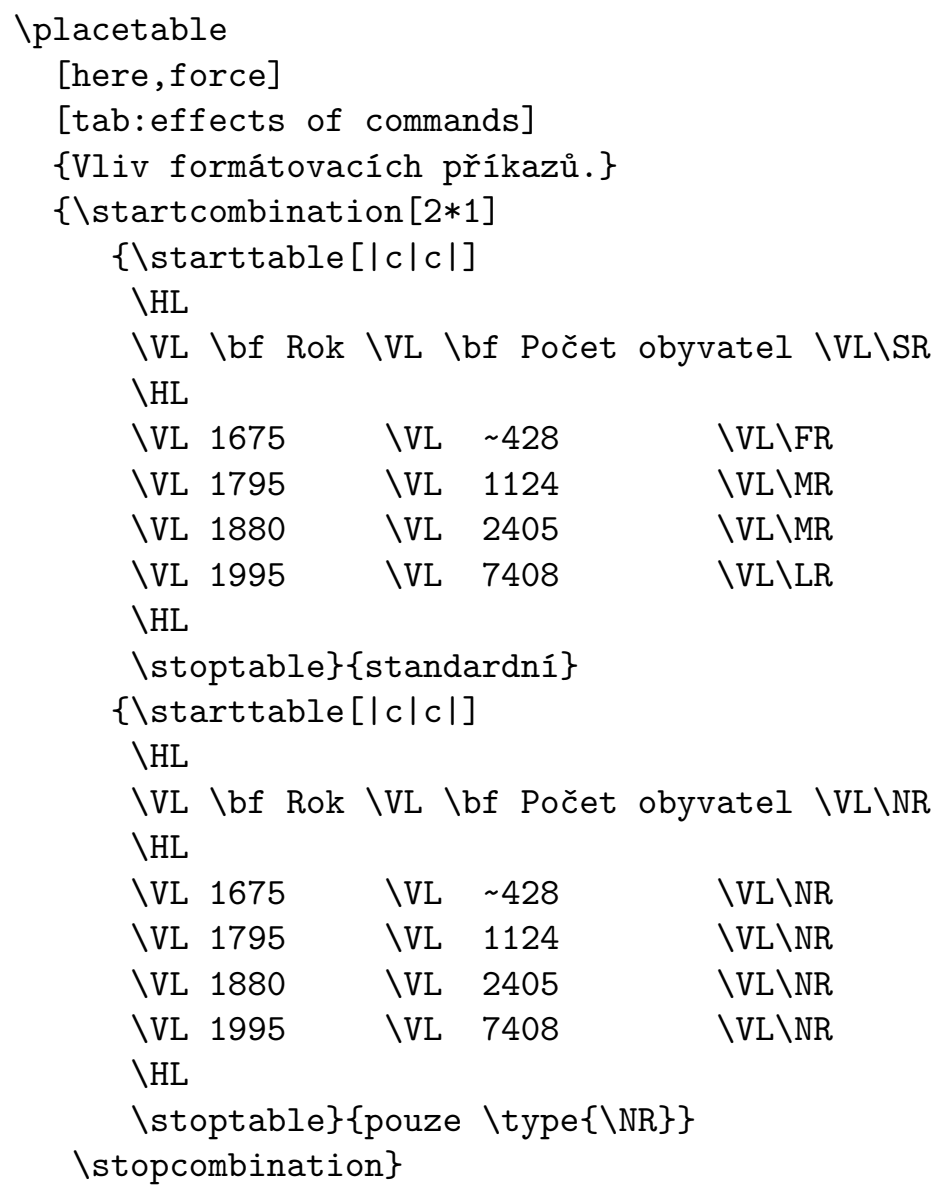

Ve výše uvedeném př́kladu jsou v první tabulce použity \SR, \FR, \MR a \LR. Tyto prŕíkazy se starají o vkládání mezer uvnitř tabulky. Jak je vidět, příkaz \NR pouze začíná novou řádku.

\begin{tabular}{|c|c|}
\hline Rok & Počet obyvatel \\
\hline 1675 & 428 \\
1795 & 1124 \\
1880 & 2405 \\
1995 & 7408 \\
\hline
\end{tabular}

standardní

\begin{tabular}{|c|c|}
\hline Rok & Počet obyvatel \\
\hline 1675 & 428 \\
1795 & 1124 \\
1880 & 2405 \\
1995 & 7408 \\
\hline
\end{tabular}

pouze \NR

Tabulka 11.5 Vliv formátovacích př́kazů.

V dalším př́íkladě je ukázáno vyrovnání sloupců pomocí značek s0 a s1.

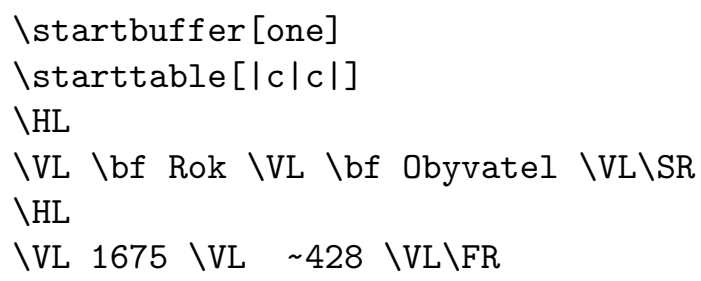


Tabulky

$\backslash V L 1795 \backslash V L \quad 1124 \backslash V L \backslash M R$

$\backslash V L 1880 \backslash V L \quad 2405 \backslash V L \backslash M R$

\VL 1995 \VL $7408 \backslash V L \backslash L R$

$\backslash \mathrm{HL}$

\stoptable

Istopbuffer

Istartbuffer [two]

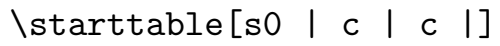

$\backslash \mathrm{HL}$

$\backslash V L \backslash b f$ Rok \VL \bf Obyvatel \VL\SR

$\backslash \mathrm{HL}$

$\backslash \mathrm{VL} 1675 \backslash \mathrm{VL} \quad \sim 428 \backslash \mathrm{VL} \backslash \mathrm{FR}$

$\backslash V L 1795 \backslash V L \quad 1124 \backslash V L \backslash M R$

$11 \backslash V L 1880 \backslash V L \quad 2405 \backslash V L \backslash M R$

\VL $1995 \backslash V L \quad 7408 \backslash V L \backslash L R$

$\backslash \mathrm{HL}$

\stoptable

Istopbuffer

Istartbuffer [three]

Istarttable[l s0 c | c | I]

$\backslash \mathrm{HL}$

\VL \bf Rok \VL \bf Obyvatel \VL\SR

$\backslash \mathrm{HL}$

\VL $1675 \backslash V L \quad \sim 428 \backslash V L \backslash F R$

\VL $1795 \backslash V L \quad 1124 \backslash V L \backslash M R$

\VL $1880 \backslash V L \quad 2405 \backslash V L \backslash M R$

\VL $1995 \backslash V L \quad 7408 \backslash V L \backslash L R$

$\backslash \mathrm{HL}$

Istoptable

Istopbuffer

\startbuffer [four]

Istarttable[l c c | so c l]

$\backslash \mathrm{HL}$

$\backslash V L \backslash b f$ Rok \VL \bf Obyvatel \VL\SR

$\backslash \mathrm{HL}$

\VL $1675 \backslash V L \quad \sim 428 \backslash V L \backslash F R$

$\backslash V L 1795 \backslash V L \quad 1124 \backslash V L \backslash M R$

$\backslash V L 1880 \backslash V L \quad 2405 \backslash V L \backslash M R$

\VL $1995 \backslash V L \quad 7408 \backslash V L \backslash L R$

$\backslash \mathrm{HL}$

\stoptable

Istopbuffer

Istartbuffer [five]

Istarttable[s1 |

$\backslash \mathrm{HL}$ 


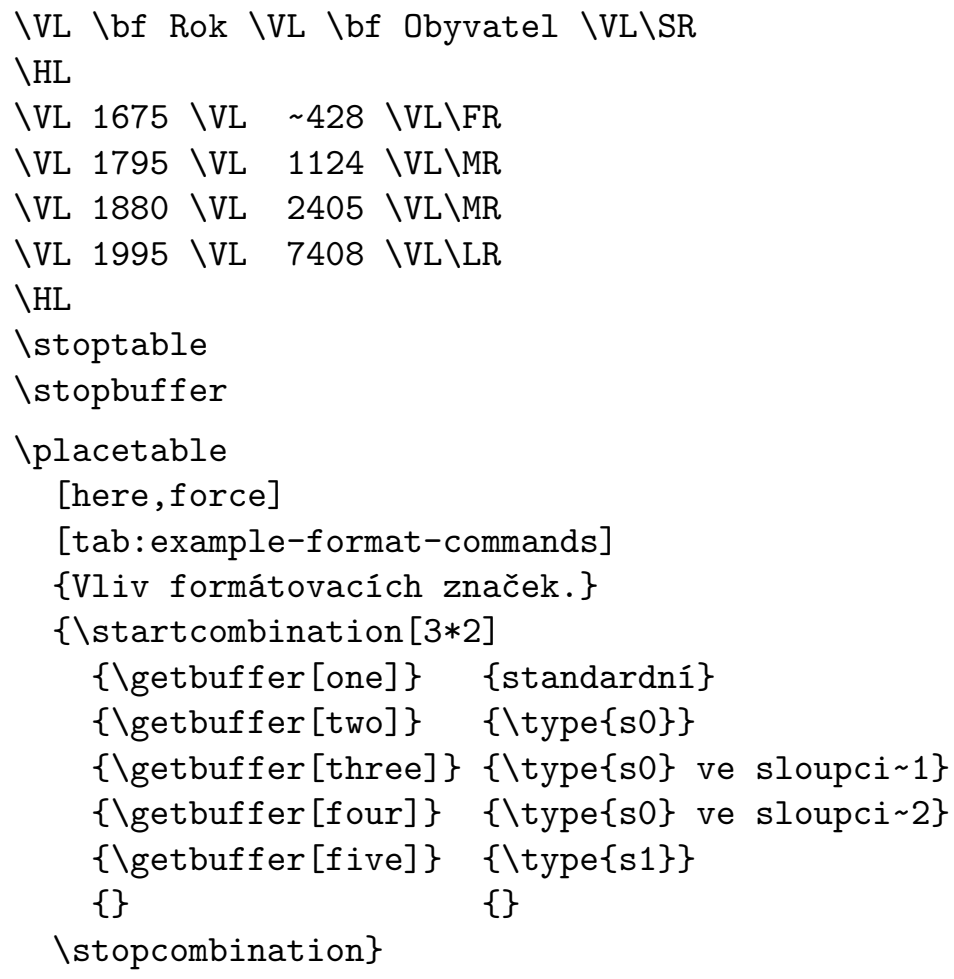

Po zpracování těchto příkladů dostaneme tabulku 11.6. Implicitní tabulka má mezerování sloupců pomocí značek s2.

\begin{tabular}{|c|c|}
\hline Rok & Obyvatel \\
\hline 1675 & 428 \\
1795 & 1124 \\
1880 & 2405 \\
1995 & 7408 \\
\hline
\end{tabular}

standardní

\begin{tabular}{|c|c|}
\hline Rok & Obyvatel \\
\hline 1675 & 428 \\
1795 & 1124 \\
1880 & 2405 \\
1995 & 7408 \\
\hline
\end{tabular}

s0 ve sloupci 2

\begin{tabular}{|c|c|}
\hline Rok & Obyvatel \\
\hline 1675 & 428 \\
1795 & 1124 \\
1880 & 2405 \\
1995 & 7408 \\
\hline
\end{tabular}

s0

\begin{tabular}{|c|c|}
\hline Rok & Obyvatel \\
\hline 1675 & 428 \\
1795 & 1124 \\
1880 & 2405 \\
1995 & 7408 \\
\hline
\end{tabular}

s1

\begin{tabular}{|c|c|}
\hline Rok & Obyvatel \\
\hline 1675 & 428 \\
1795 & 1124 \\
1880 & 2405 \\
1995 & 7408 \\
\hline
\end{tabular}

s0 ve sloupci 1

Tabulka 11.6 Vliv formátovacích značek.

Sloupce bývají občas odděleny svislými linkami | a řádky vodorovnými.

\footnotetext{
$\backslash$ placetable

[here,force]

[tab:divisions]
} 
Tabulky

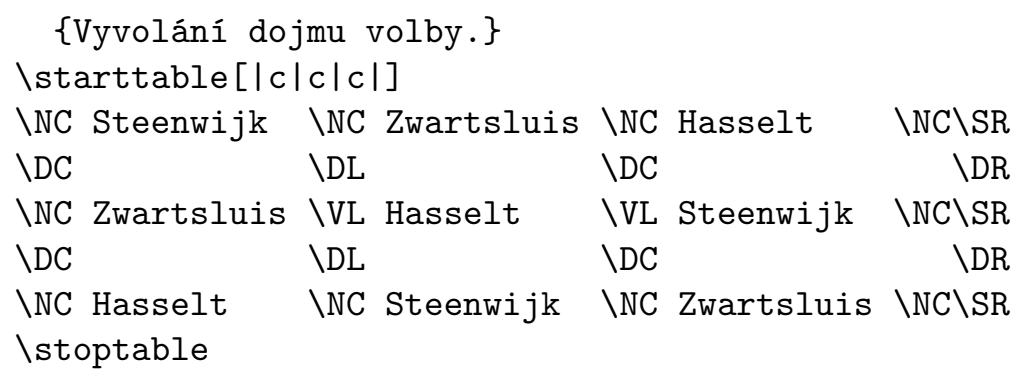

\begin{tabular}{ccc} 
Steenwijk & Zwartsluis & \multicolumn{1}{c}{ Hasselt } \\
Zwartsluis & Hasselt & Steenwijk \\
\cline { 2 - 2 } Hasselt & Steenwijk & Zwartsluis
\end{tabular}

Tabulka 11.7 Vyvolání dojmu volby.

Praktičtější př́iklad je v tabulce 11.8 .

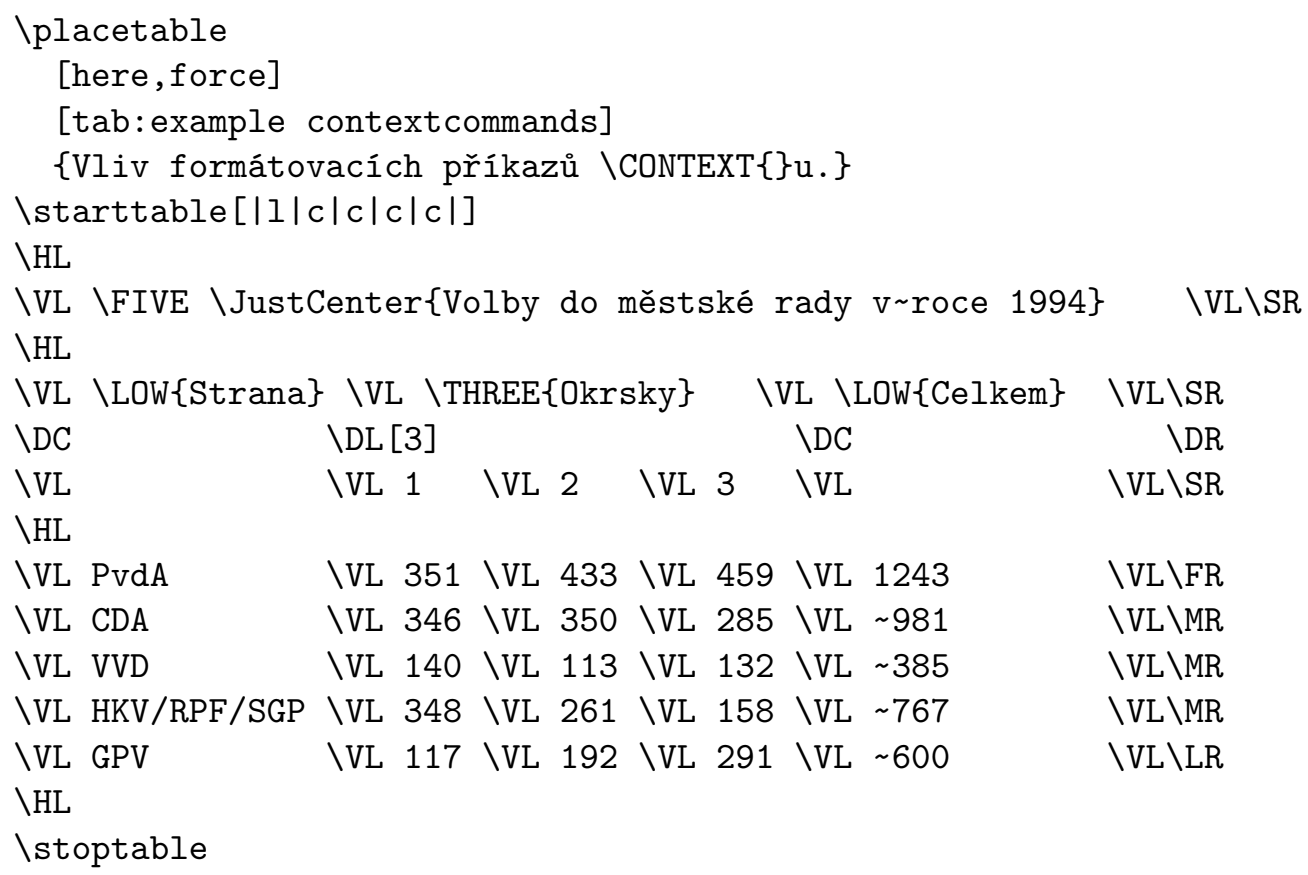

V posledním sloupci je znak použit k simulaci čtyřciferného čísla. Znak má šířku cifry.

Někdy se nám tabulka přiliš rozroste. Abychom ji vysadili s textem, můžeme například zmenšit použité písmo. Pomocí př́íkazu 
Tabulky

\begin{tabular}{|l|c|c|c|c|}
\hline \multicolumn{5}{|c|}{ Volby do městské rady v roce 1994} \\
\hline \multirow{2}{*}{ Strana } & \multicolumn{3}{|c|}{ Okrsky } & \multirow{2}{*}{ Celkem } \\
\cline { 2 - 5 } & 1 & 2 & 3 & \\
\hline PvdA & 351 & 433 & 459 & 1243 \\
CDA & 346 & 350 & 285 & 981 \\
VVD & 140 & 113 & 132 & 385 \\
HKV/RPF/SGP & 348 & 261 & 158 & 767 \\
GPV & 117 & 192 & 291 & 600 \\
\hline
\end{tabular}

Tabulka 11.8 Vliv

formátovacích př́ḱkazů CONTEXTu.

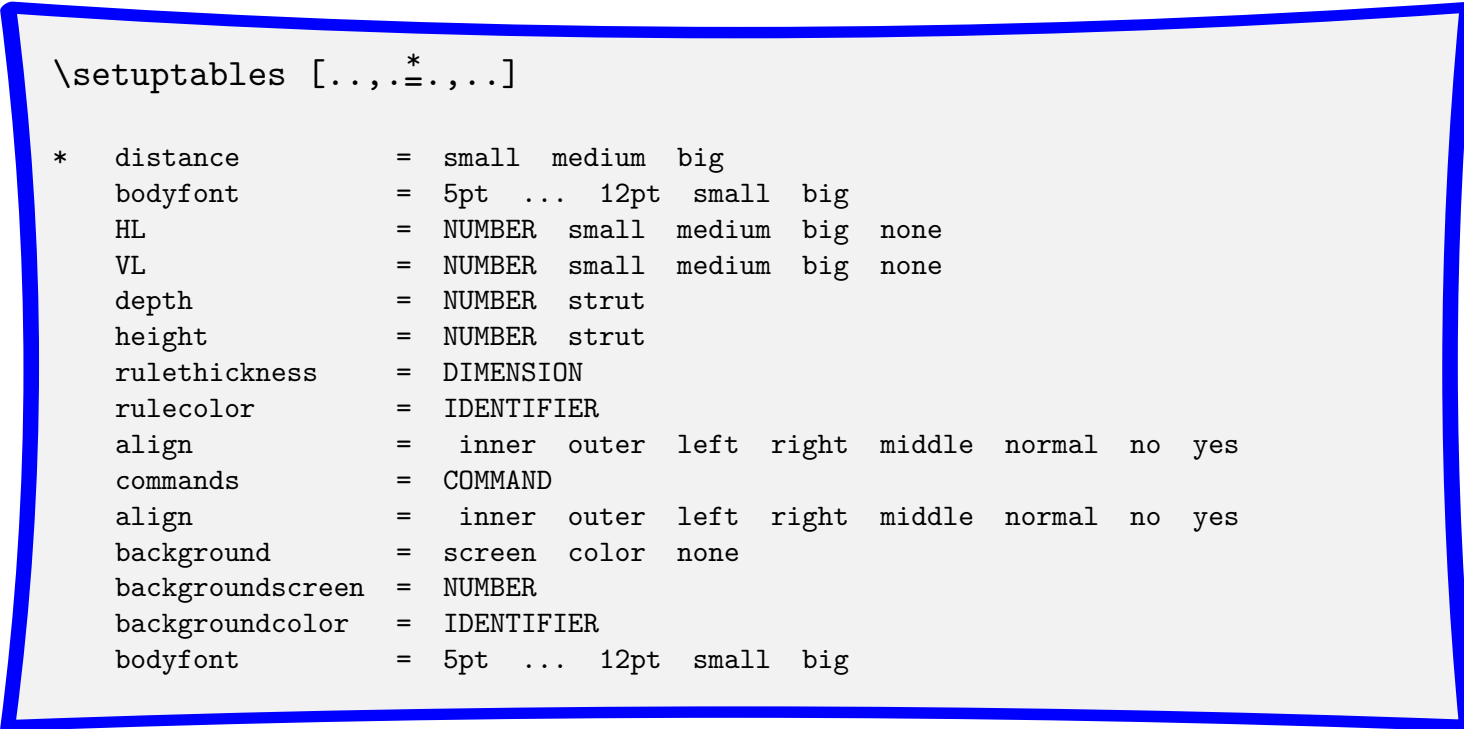

to uděláme takto:

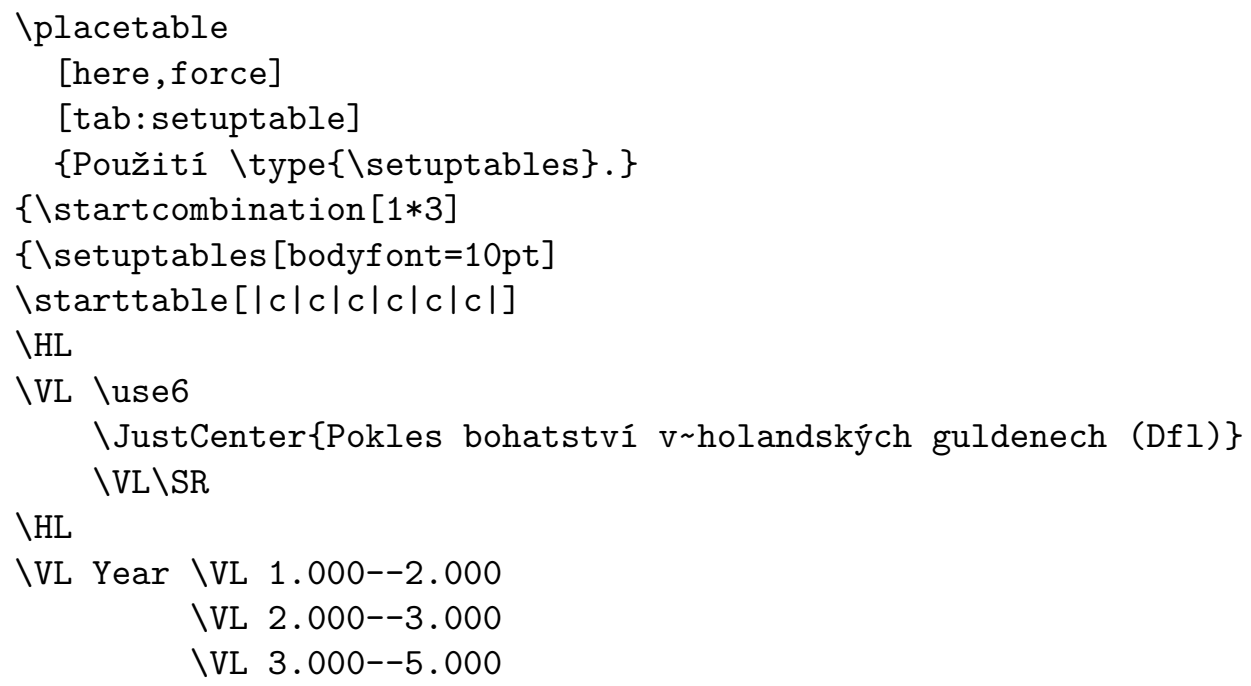

$\backslash \mathrm{HL}$

\VL Year \VL 1.000--2.000

IVL $2.000--3.000$

IVL $3.000--5.000$ 
Tabulky

IVL $5.000--10.000$

$\backslash V L$ přes $10.000 \backslash V L \backslash S R$

$\backslash \mathrm{HL}$

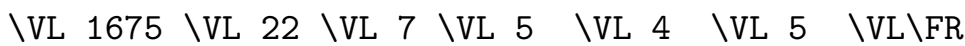

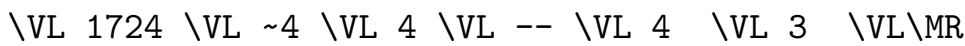

$\backslash V L 1750 \backslash V L 12 \backslash V L 3 \backslash V L 2 \quad \backslash V L 2 \quad \backslash V L ~--~ \backslash V L \backslash M R$

\VL $1808 \backslash \mathrm{VL} \sim 9 \backslash \mathrm{VL} 2 \backslash \mathrm{VL}--\backslash \mathrm{VL}--\backslash \mathrm{VL}--\backslash \mathrm{VL} \backslash \mathrm{LR}$

$\backslash \mathrm{HL}$

\stoptable $\}\{\backslash$ tt bodyfont=10pt $\}$

$\{\backslash$ setuptables [bodyfont $=8 \mathrm{pt}$ ]

$\backslash$ starttable $[|c| c|c| c|c| c \mid]$

$\backslash \mathrm{HL}$

IVL \use6

$\backslash$ JustCenter\{Pokles bohatství V^holandských guldenech (Dfl)\} $\backslash \mathrm{VL} \backslash \mathrm{SR}$

$\backslash \mathrm{HL}$

IVL Year \VL 1.000--2.000

IVL $2.000--3.000$

$\backslash$ VL $3.000--5.000$

IVL 5.000--10.000

$\backslash V L$ over $10.000 \backslash V L \backslash S R$

$\backslash \mathrm{HL}$

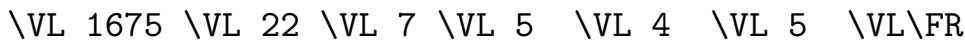

\VL $1724 \backslash V L \sim 4 \backslash V L 4 \quad \backslash V L$-- \VL $4 \quad \backslash V L$

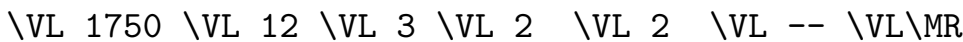

\VL $1808 \backslash \mathrm{VL} \sim 9 \backslash \mathrm{VL} 2 \backslash \mathrm{VL}--\backslash \mathrm{VL}--\backslash \mathrm{VL}--\backslash \mathrm{VL} \backslash \mathrm{LR}$

$\backslash \mathrm{HL}$

\stoptable $\}\{$ tt bodyfont $=8 \mathrm{pt}\}$

$\{\backslash$ setuptables [bodyfont $=6 \mathrm{pt}$, distance=small]

$\mid$ starttable $[|c| c|c| c|c| c \mid]$

$\backslash \mathrm{HL}$

IVL \use6

$\backslash$ JustCenter\{Pokles bohatství V $\sim$ holandských guldenech (Dfl)\} $\backslash \mathrm{VL} \backslash \mathrm{SR}$

$\backslash \mathrm{HL}$

IVL Year \VL 1.000--2.000

IVL $2.000--3.000$

IVL $3.000--5.000$

IVL $5.000--10.000$

$\backslash V L$ přes $10.000 \backslash V L \backslash S R$

$\backslash \mathrm{HL}$

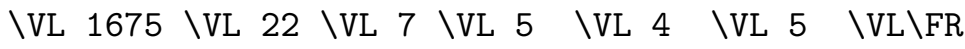

$\backslash V L 1724 \backslash V L \sim 4 \backslash V L 4 \backslash V L$-- \VL $4 \quad \backslash V L 3 \quad \backslash V L \backslash M R$

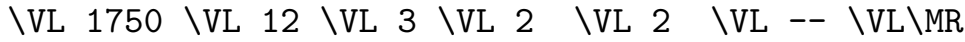

\VL $1808 \backslash V L \sim 9 \backslash V L 2 \backslash V L$-- \VL -- \VL -- \VL \LR

$\backslash \mathrm{HL}$ 
Tabulky

\stoptable $\}\{$ tt bodyfont=6pt, distance=small $\}$

$\backslash$ stopcombination\}

\begin{tabular}{|c|c|c|c|c|c|}
\hline \multicolumn{7}{|c|}{ Pokles bohatství v holandských guldenech (Dfl) } \\
\hline Year & $1.000-2.000$ & $2.000-3.000$ & $3.000-5.000$ & $5.000-10.000$ & přes 10.000 \\
\hline 1675 & 22 & 7 & 5 & 4 & 5 \\
1724 & 4 & 4 & - & 4 & 3 \\
1750 & 12 & 3 & 2 & 2 & - \\
1808 & 9 & 2 & - & - & - \\
\hline
\end{tabular}

bodyfont $=10 \mathrm{pt}$

\begin{tabular}{|c|c|c|c|c|c|}
\hline \multicolumn{6}{|c|}{ Pokles bohatství v holandských guldenech (Dfl) } \\
\hline Year & $1.000-2.000$ & $2.000-3.000$ & $3.000-5.000$ & $5.000-10.000$ & over 10.000 \\
\hline 1675 & 22 & 7 & 5 & 4 & 5 \\
1724 & 4 & 4 & - & 4 & 3 \\
1750 & 12 & 3 & 2 & 2 & - \\
1808 & 9 & 2 & - & - & - \\
\hline
\end{tabular}

bodyfont $=8 \mathrm{pt}$

\begin{tabular}{|c|c|c|c|c|c|}
\hline \multicolumn{6}{|c|}{ Pokles bohatstvív holandských guldenech (Dfl) } \\
\hline Year & $1.000-2.000$ & $2.000-3.000$ & $3.000-5.000$ & $5.000-10.000$ & přes 10.000 \\
\hline 1675 & 22 & 7 & 5 & 4 & 5 \\
1724 & 4 & 4 & - & 4 & 3 \\
1750 & 12 & 3 & 2 & 2 & - \\
1808 & 9 & 2 & - & - & - \\
\hline
\end{tabular}

bodyf ont $=6 \mathrm{pt}$, distance $=\operatorname{small}$

Tabulka 11.9 Použití \setuptables.

Nastavit umístění tabulek můžeme také pomocíjiž známého 
Tabulky

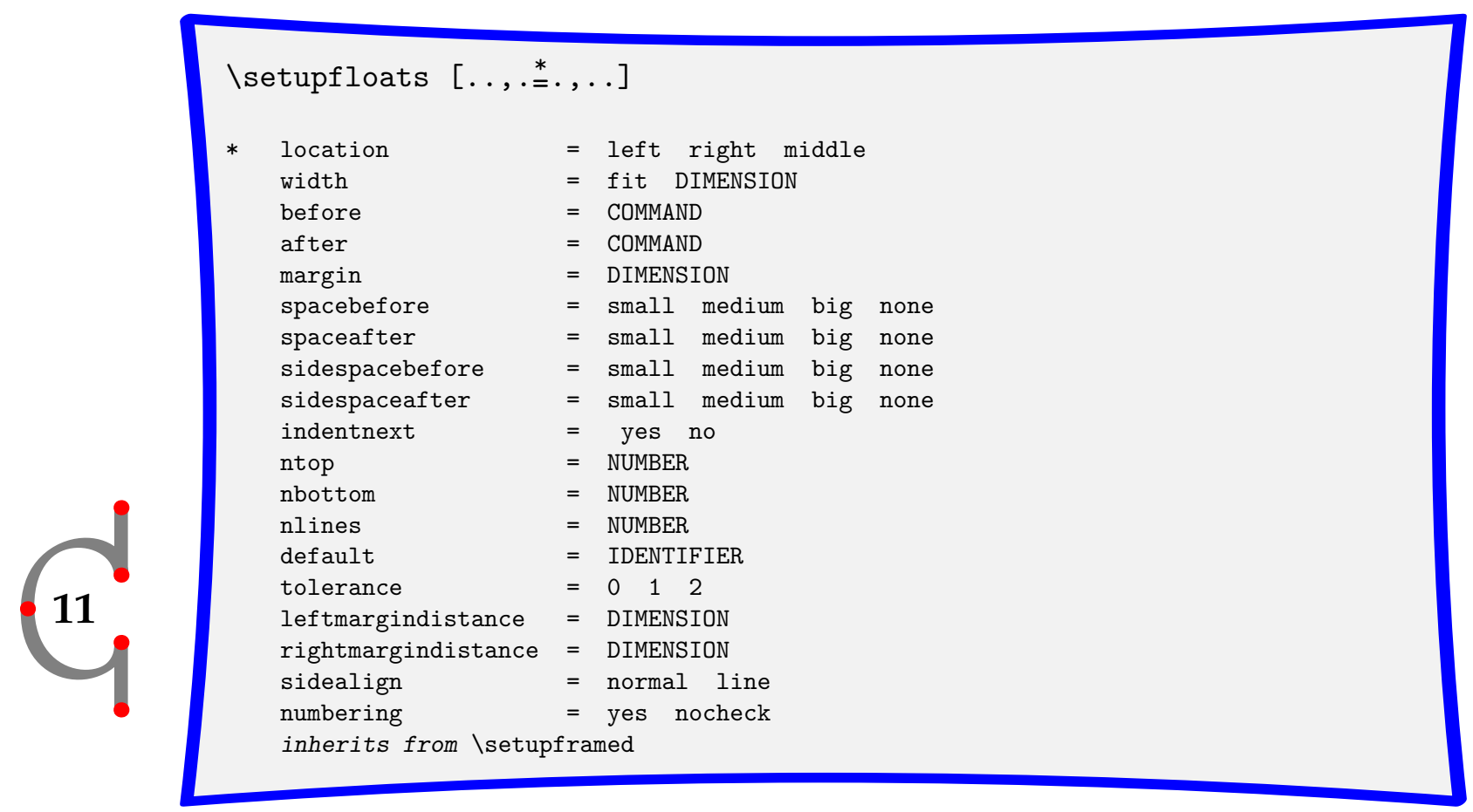

Číslování a popisky nastavíme příkazem

\setupcaptions $[\ldots, . . *, .$.

* location $=$ top bottom none high low middle

width $=$ fit broad $\max$ DIMENSION

minwidth $\quad=$ fit DIMENSION

headstyle $=$ normal bold slanted boldslanted type cap small... COMMAND

style $\quad=$ normal bold slanted boldslanted type cap small... COMMAND

number $\quad=$ yes no

inbetween $=$ COMMAND

align $=$ inner outer left right middle normal no yes

conversion $=$ numbers characters Characters romannumerals Romannumerals

way $\quad=$ bytext bycd:section

separator $=$ TEXT

stopper $\quad=$ TEXT

command $=$ COMMAND

distance $\quad=$ DIMENSION

Tyto př́ikazy používáme v deklarační oblasti našeho vstupního souboru a mají globální platnost.

\setupfloats [location=left]

Isetupcaption [style=boldslanted]

$\backslash$ placetable[here] [tab:opening hours]\{0tevírací hodiny knihovny.\}

sstarttable $[\mid]|c| c \mid]$

$\backslash \mathrm{HL}$

\VL \bf Den \VL \use2 \bf Otevírací hodiny

$\backslash \mathrm{VL} \backslash \mathrm{SR}$

$\backslash \mathrm{HL}$ 


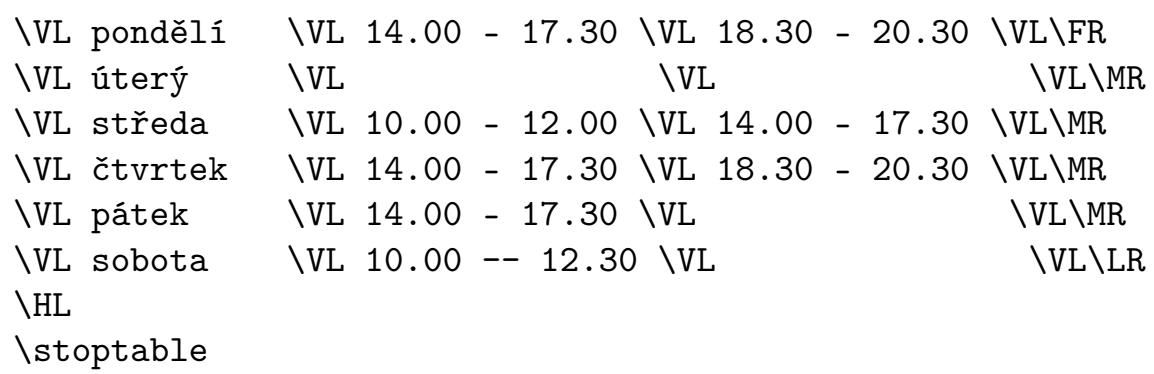

Výsledek zobrazuje tabulka 11.10.

\begin{tabular}{|l|c|c|}
\hline Den & \multicolumn{2}{|c|}{ Otevírací hodiny } \\
\hline $\begin{array}{l}\text { pondělí } \\
\text { úterý }\end{array}$ & $14.00-17.30$ & $18.30-20.30$ \\
středa & $10.00-12.00$ & $14.00-17.30$ \\
čtvrtek & $14.00-17.30$ & $18.30-20.30$ \\
pátek & $14.00-17.30$ & \\
sobota & $10.00-12.30$ & \\
\hline
\end{tabular}

Tabulka 11.10 Otevírací hodiny knihovny.

\section{Tabelace / formátování odstavce}

Někdy chceme vysázet odstavce zformátované určitým přesně daným zpơsbem. Toho lze dosáhnout pomocí:

Istarttabulate $[.1] \quad.[.2.] \quad \ldots \quad$ Istoptabulate

1 TEXT

2 TEXT

Technika tabelace je úzce svázána s technikou tvorby tabulek. Tabelaci lze využít v těch případech, kdy chcete do buňky tabulky vysázet kompletní odstavec. Tabelace funguje dobře i při stránkovém zlomu.

Definice tabelace vypadá nějak takto: 
Tabelace / formátování odstavce

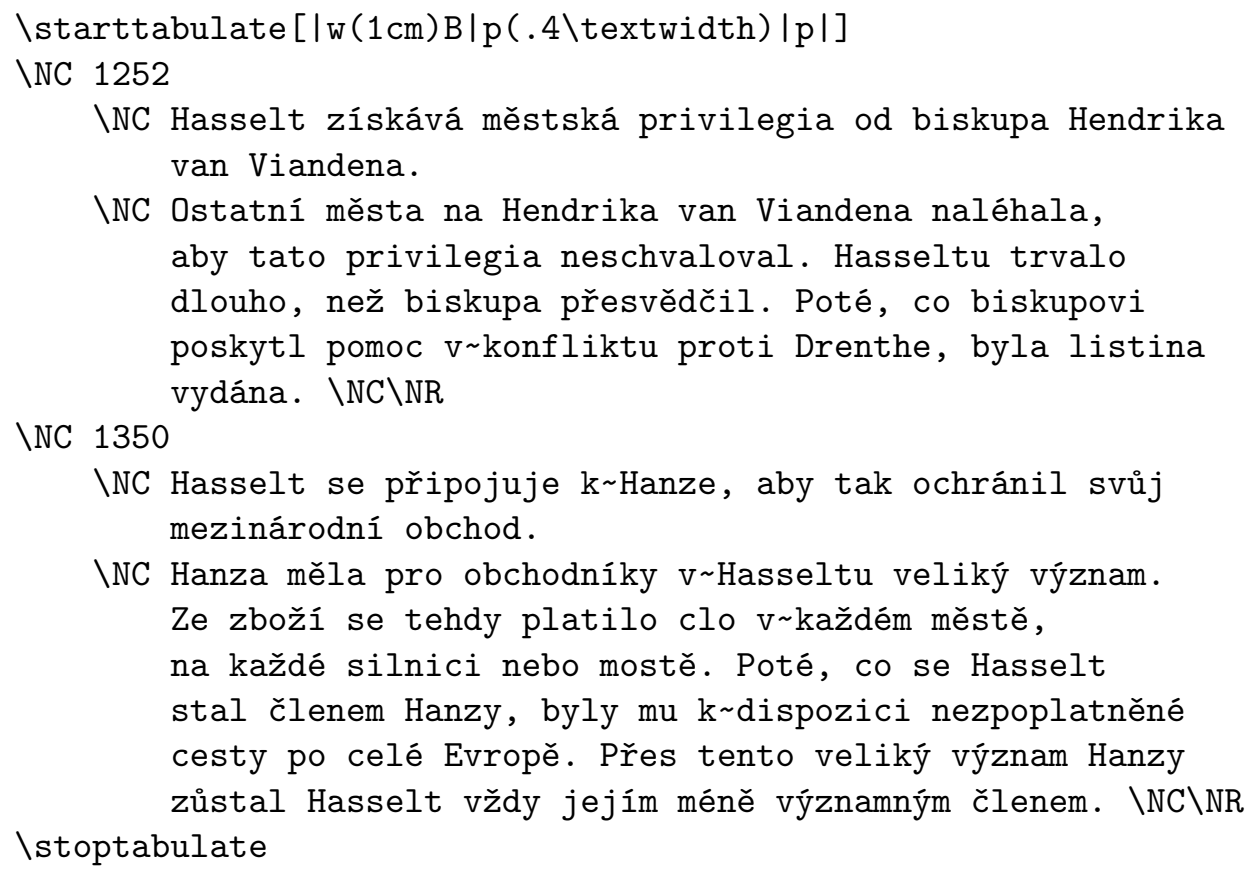

V tomto případě má první sloupec šiřku $1 \mathrm{~cm}$ a je vysázen tučným řezem (B). Druhý sloupec má šířku $40 \%$ šířky odstavce a je vysázen jako odstavec. Zbývající horizontální místo je využito posledním odstavcem.

Uvedený př́klad se vysází takto:

1252 Hasselt získává městská privilegia od biskupa Hendrika van Viandena.

Ostatní města na Hendrika van Viandena naléhala, aby tato privilegia neschvaloval. Hasseltu trvalo dlouho, než biskupa přesvědčil. Poté, co biskupovi poskytl pomoc v konfliktu proti Drenthe, byla listina vydána.

1350 Hasselt se připojuje k Hanze, aby tak ochránil svůj mezinárodní obchod.

Hanza měla pro obchodníky v Hasseltu veliký význam. Ze zboží se tehdy platilo clo v každém městě, na každé silnici nebo mostě. Poté, co se Hasselt stal členem Hanzy, byly mu k dispozici nezpoplatněné cesty po celé Evropě. Přes tento veliký význam Hanzy zůstal Hasselt vždy jejím méně významným členem.

Stejně jako v tabulkách i zde je k dispozici mnoho formátovacích povelů a parametrů. Jejich seznam je uveden $\mathrm{v}$ tabulce 12.1 .

Jiný příklad formátování odstavce by mohl vypadat takto:

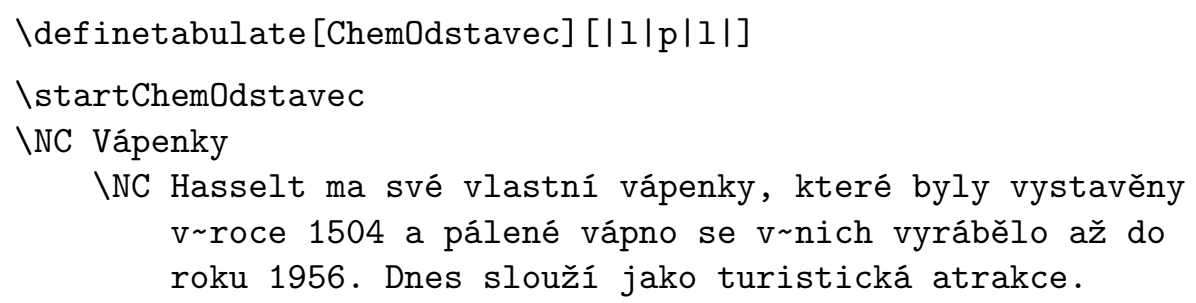


Tabelace / formátování odstavce

\begin{tabular}{|c|c|c|c|}
\hline 1 & zarovnání vlevo & I & italika \\
\hline c & zarovnání na střed & $\mathrm{R}$ & antikva \\
\hline$r$ & zarovnání vpravo & $\mathrm{S}$ & skloněné \\
\hline in & odsazení vlevo & $\mathrm{T}$ & psací stroj \\
\hline jn & odsazení vpravo & $\mathrm{m}$ & vnitřní matematický mód \\
\hline $\mathrm{kn}$ & mezera okolo & M & display matematický mód \\
\hline $\mathrm{W}(d)$ & 1 řádka, pevná šířka & $f \backslash$ command & určení řezu písma \\
\hline $\mathrm{p}(d)$ & odstavec, pevná šířka & barg. . & umístit . . před položku \\
\hline $\mathrm{p}$ & odstavec, maximální šířka & aarg. . & umístit . . za položku \\
\hline$B$ & tučný řez & $\mathrm{h} \backslash$ command & aplikovat na položku \command \\
\hline
\end{tabular}

Tabulka 12.1 Povely pro tabelaci.

$\backslash \mathrm{NC} \backslash$ chemical $\left\{\mathrm{CaCO} 33, \sim, \mathrm{GIVES}, \sim, \mathrm{CaO}, \sim,+, \sim, \mathrm{CO}_{-} 2\right\} \backslash \mathrm{NC} \backslash \mathrm{NR}$ \stopChemOdstavec

Vysází se to následovně:

Vápenky Hasselt ma své vlastní vápenky, které byly vystavěny v ro- $\mathrm{CaCO}_{3} \longrightarrow \mathrm{CaO}+\mathrm{CO}_{2}$ ce 1504 a pálené vápno se v nich vyrábělo až do roku 1956. Dnes slouží jako turistická atrakce.

Modul pro chemickou sazbu je vysvětlen v jiném manuálu, protože ne každý se zajímá o chemii. Také jsme zde uvedli povel pro definici tabelačního schematu ChemOdstavec

\definetabulate $[. .1] \quad.[.2 .] \quad.[.3 .$.

1 IDENTIFIER

2 IDENTIFIER

3 TEXT

a existuje také: 
Isetuptabulate $\underset{\text { OPTIONAL }}{[.1 .]}[\ldots, \stackrel{2}{=}, \ldots]$

1 IDENTIFIER

2 unit = DIMENSION

indenting $=$ never none not no yes always first next small medium big normal odd even DIMENSION

before $\quad=$ COMMAND

after $\quad=$ COMMAND

inner $\quad=$ COMMAND

$\mathrm{EQ} \quad=$ TEXT

rulecolor $\quad=$ IDENTIFIER

align $\quad=$ inner outer left right middle normal no yes

rulethickness $=$ DIMENSION

distance $=$ blank grid depth DIMENSION small medium big none

bodyfont $\quad=5 p t \ldots 12 p t$ small big

rule

$=5 \mathrm{pt} \ldots$...

split

$=$ yes no

\section{Sloupce}

Nepř́liš složité dokumenty je možné sázet do sloupců. Jestliže kus textu zahájíme př́ikazem \startcolumns a ukončíme \stopcolumns, veškerý takto obklopený materiál bude formátován do sloupců. ${ }^{7}$

\startcolumns $[\ldots, . . *, \ldots] \ldots$ \stopcolumns

OPTIONAL

* inherits from \setupcolumns

\startcolumns [n=3, tolerance=verytolerant]

Hasselt je staré hanzovní město, položené 12\,km severně od Zwolle na řece Zwartewater.

Má bohatou historii, která se začíná kolem roku 1252, kdy Hasselt obdržel městská práva. Tuto historii můžeme rozkrývat pomocí velkého počtu památek v centru města.

7 Složitější dokument, napřs. s plovoucími obrázky, je lépe sázet pomocí \startcolumnsets ... \stopcolumnsets. Popis lze najít v manuálu http://www.pragma-ade.com/general/manuals/columns.pdf, viz přílohu A. Pozn. překl. 
Nalezneme zde pozdněgotický kostel Sv. Štěpána založený roku 1479 s velkolepými varhanami. Budova bývalé radnice, která se nalézá na Tržním náměstí, byla postavena mezi roky 1500 a 1550 a dnes v něm sídlí muzeum zbraní. Za zmínku stojí zejména sbírka děl na černý střelný prach (haakhussen), která se řadí k největším na světě.

Dále je zde větrný mlýn \quote\{De Zwaluw\} (Vlaštovka) na mletí mouky z roku 1748, unikátní nábřeží lquote\{Stenendijk\} a v Vvropě poslední stará plně funkční vápenka.

Centrum města s kanály lemovanými lípami, oblast Van Stolkspark a dok plný ruchu a hemžení jsou ideální místa k procházkám.

Okolí Hasseltu stojí ovšem též za zmínku. V zimě hostí polder Mastenbroek velká stáda ovcí. V létě tvoři vesničky Genne, Streukel a Celle\-mui \-den s velice vzácnou květinou řebčíkem kostkovaným (lat. Fritillaria meleagris) výborné prostředí pro pěši i cyklistické výlety .

Hasselt je také velice důležité město vodních sportů. Jezera severozápadně od Overijssel, řeky IJssel, Overijsselse Vecht a Randmeren jsou snadno dosažitelné $z \sim$ přistavu jachet lquote\{De Molenwaard\}. Mořeplavbu, rybolov, plavání a jízdu na kanoi si v Hasseltu můžete vychutnat naplno.

A na závěr uvedeme jednu událost obzvláštního významu. Každoročně se na konci srpna v Hasseltu slaví dožínky - Iquote\{Eui

Festival\}.

\stopcolumns

Výsledkem bude třísloupcový text.

Hasselt je staré hanzovní město, položené $12 \mathrm{~km}$ severně od Zwolle na řece Zwartewater.

Má bohatou historii, která se začíná kolem roku 1252, kdy Hasselt obdržel městská práva. Tuto historii můžeme rozkrývat pomocí velkého počtu památek $\mathrm{v}$ centru města.

Nalezneme zde pozdněgotický kostel Sv. Štěpána založený roku 1479 s velkolepými varhanami. Budova bývalé radnice, která se nalézá na Tržním náměstí, byla postavena mezi roky 1500 a 1550 a dnes v něm sídlí muzeum zbraní. Za zmínku stojí zejména sbírka děl na černý střelný prach (ha- akhussen), která se řadí k největším na světě.

Dále je zde větrný mlýn ,De Zwaluw' (Vlaštovka) na mletí mouky z roku 1748, unikátní nábřeží ,Stenendijk' a v Evropě poslední stará plně funkční vápenka.

Centrum města s kanály lemovanými lípami, oblast Van Stolkspark a dok plný ruchu a hemžení jsou ideální místa k procházkám.

Okolí Hasseltu stojí ovšem též za zmínku. V zimě hostí polder Mastenbroek velká stáda ovcí. V létě tvoří vesničky Genne, Streukel a Cellemuiden s velice vzácnou květinou řebčíkem kostkovaným (lat. Fritillaria meleagris) výborné prostředí pro pěší i cyklistické výlety.

Hasselt je také velice důležité město vodních sportů. Jezera severozápadně od Overijssel, řeky IJssel, Overijsselse Vecht a Randmeren jsou snadno dosažitelné z prístavu jachet ,De Molenwaard'. Mořeplavbu, rybolov, plavání a jízdu na kanoi si v Hasseltu můžete vychutnat naplno.

A na závěr uvedeme jednu událost obzvláštního významu. Každoročně se na konci srpna v Hasseltu slaví dožínky - ,Eui Festival'. $^{\prime}$ 
Je-li to potřeba, pak přechod do nového sloupce může být vynucen pomocí \column. Sloupce nastavíme př́kazem

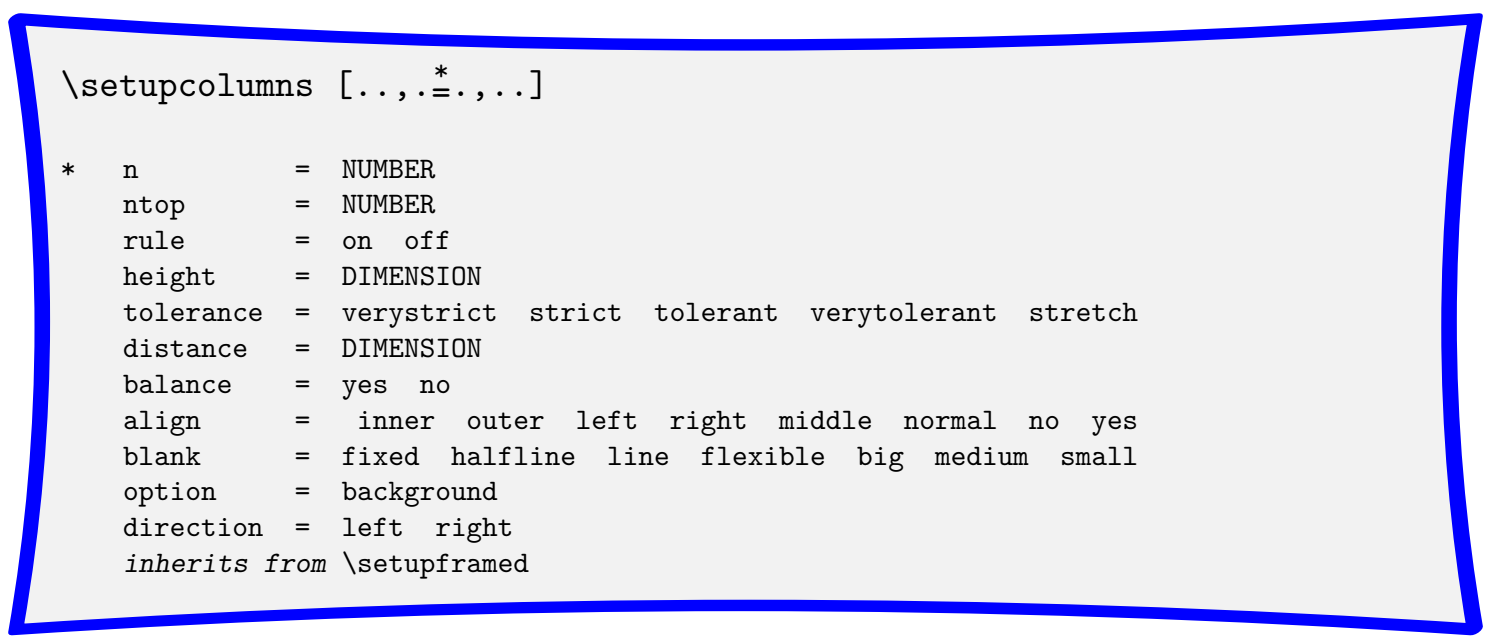

Ve většině případů dosáhneme při sazbě do sloupců lepších výsledků, zapneme-li sazbu do řádkového rejstř́ku. To se nastavuje parametrem grid=yes v př́kazu \setuplayout.

\section{Poznámky pod čarou}

Pokud chceme opatřit text poznámkou, můžeme použít \footnote. Př́kaz vypadá takto:

$\backslash$ footnote $\underset{\text { OPTIONAL }}{[.1 .]}\{.2$.

1 REFERENCE

2 TEXT

Hranaté závorky jsou nepovinné a obsahují referenční jméno poznámky pod čarou. Složené závorky obsahují text, který chcete zobrazit pod čarou.

Číslo poznámky pod čarou můžeme získat napsáním referenčního jména do 
$\backslash$ note $[. * .$.

* REFERENCE

Pokud napíšeme text

Hanza byla pozdně středověká obchodní aliance měst $\mathrm{v}$ oblasti

Severního a Baltského moře. Tento spolek byl sestaven na podporu a

ochranu obchodování svých členů. \footnote[war]\{Tento systém byl také

zdrojem závisti a strachu mezi ostatními městy a

zapřičinil mnohé válečné střety.\}

V období hanzovního systému zde panoval čilý obchodní ruch s veškerým

zbožím jako dřevo, vlna, kovy, látky, sůl, víno a pivo.\note[war]

Fungující obchod způsobil enormní růst prosperity a blahobytu

v hanzovních městech. \footnote\{Jedním $z$ těchto měst je Hasselt.\}

pak bude vypadat takto:

Hanza byla pozdně středověká obchodní aliance měst v oblasti Severního a Baltského moře. Tento spolek byl sestaven na podporu a ochranu obchodování svých členů. ${ }^{8} \mathrm{~V}$ období hanzovního systému zde panoval čilý obchodní ruch s veškerým zbožím jako dřevo, vlna, kovy, látky, sůl, víno a pivo. ${ }^{8}$ Fungující obchod způsobil enormní růst prosperity a blahobytu v hanzovních městech. ${ }^{9}$

Číslování poznámek se provádí automaticky. Příkaz \setupfootnotes nám umožní ovlivnit vzhled poznámky.

\footnotetext{
8 Tento systém byl také zdrojem závisti a strachu mezi ostatními městy a zapř̌čcinil mnohé válečné střety.

9 Jedním z těchto měst je Hasselt.
} 


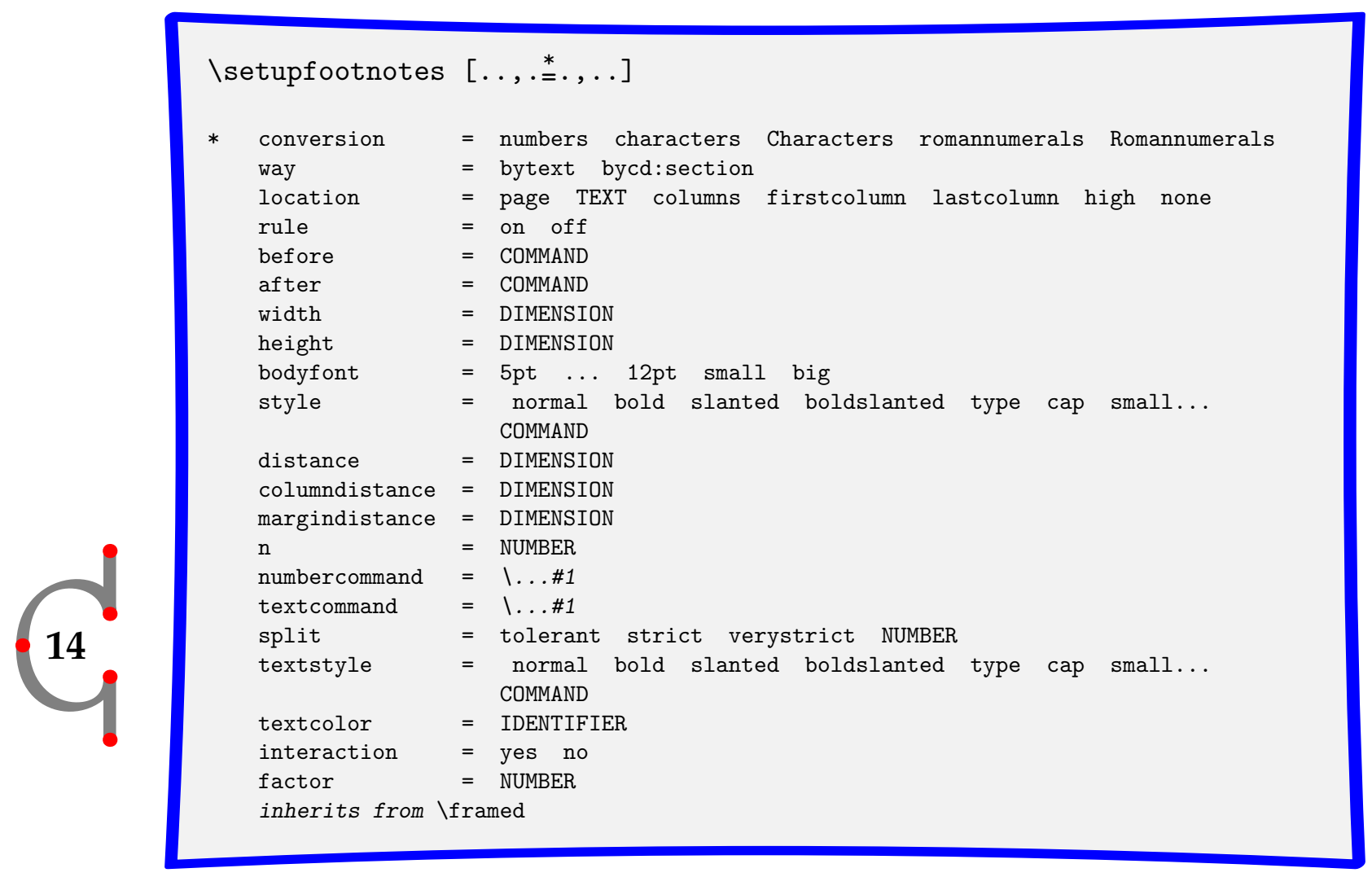

Poznámky mohou být umístěny ve spodní části stránky, ale také jinde, např. na konci kapitoly. To provádíme nastavením location=none a uvedením \placefootnotes na konci kapitoly.

$\backslash p l a c e f o o t n o t e s \quad[\ldots, . * *, \ldots]$

OPTIONAL

* inherits from \setupfootnotes

Poznámka se také může přiřadit $\mathrm{k}$ tabulce. $\mathrm{V}$ takovém př́ípadě hovoříme o lokálních poznámkách. Pro tento účel existují následující př́kazy:

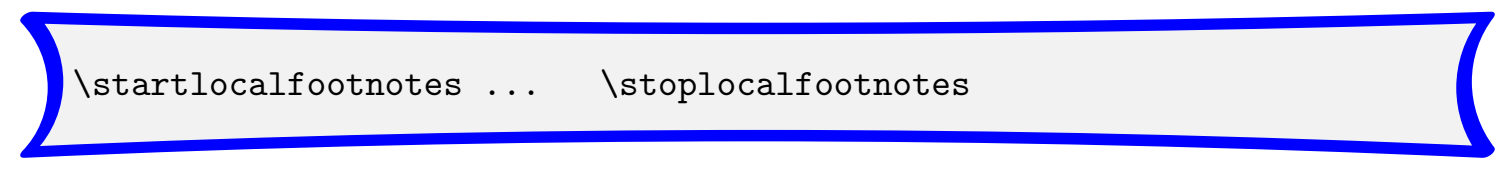

$\backslash p l a c e l o c a l f o o t n o t e s \quad[\ldots, . * *, .$.

OPTIONAL

* inherits from \setupfootnotes

Ilustrující př́íklad použití lokálních poznámek: 


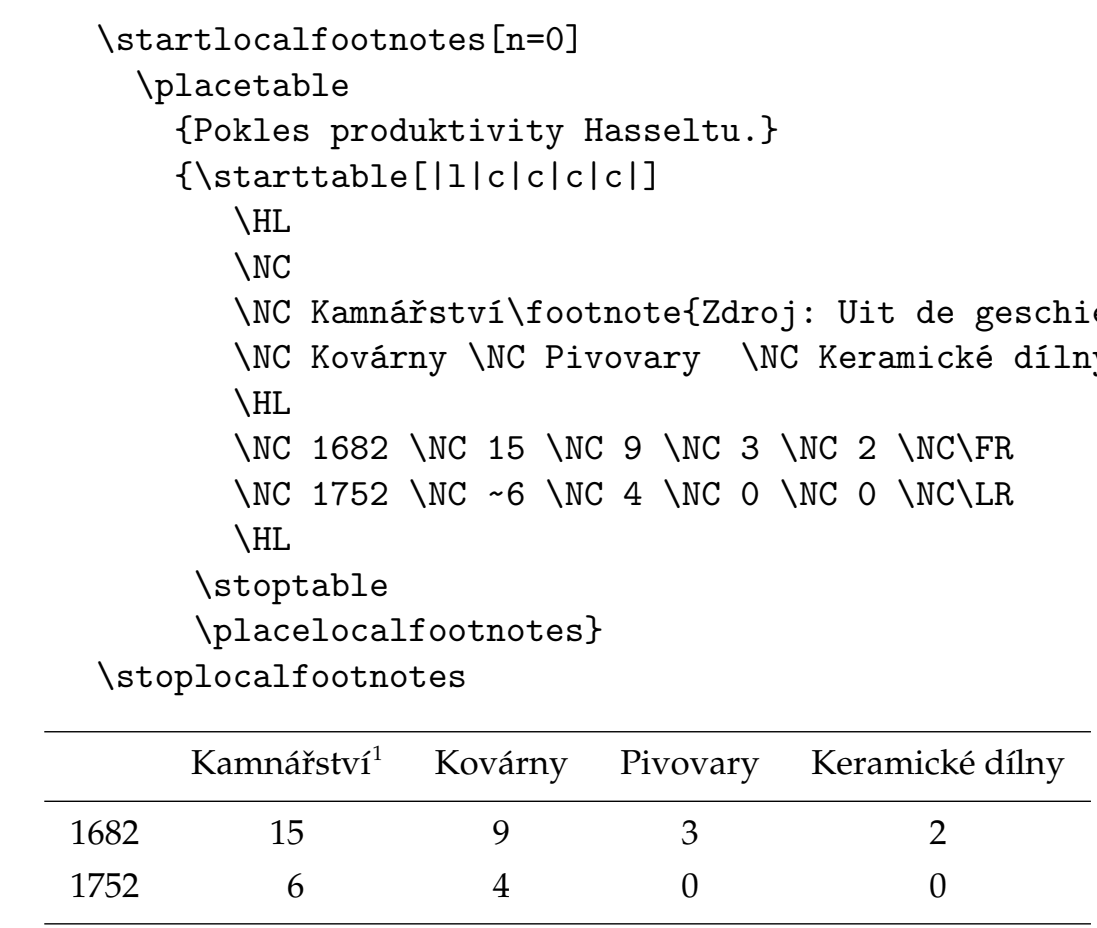

${ }^{1}$ Zdroj: Uit de geschiedenis van Hasselt.

Tabulka 14.1 Pokles produktivity Hasseltu.

\section{Definice pojmů}

Pokud chceme poznámky, koncepty a myšlenky sázet jednotným způsobem, můžeme použít:

\definedescription $[. \stackrel{1}{.}][\ldots, . \stackrel{2}{=} ., \ldots]$

OPTIONAL

1 IDENTIFIER

2 inherits from \setupdescriptions

Př́ílad:

Idefinedescription

[concept]

[location=serried, headstyle=bold, width=broad] 
\concept\{Hasseltské juffers:\} Druh sušenky, vyrobený z nadýchaného těsta, sypaný cukrem. Je velmi sladký. Ipar

bude vypadat takto:

Hasseltské juffers: Druh sušenky, vyrobený z nadýchaného těsta, sypaný cukrem. Je velmi sladký.

Můžeme také použít jiné formátování:

\section{Hasseltská hořká:}

Silný alkoholický nápoj (40\%) s přidanými bylinkami a velmi specifickou chutí. Prodává se v kameninových lahvičkách a podává se ijskoud (ledová).

Euifeest: Dožínky, oslava sklizně a konce období lopotné práce. Tyto slavnosti se konají poslední týden v srpnu.

Máme-li v takové definici více odstavců, použijeme dvojici \start. . .-\stop. . . :
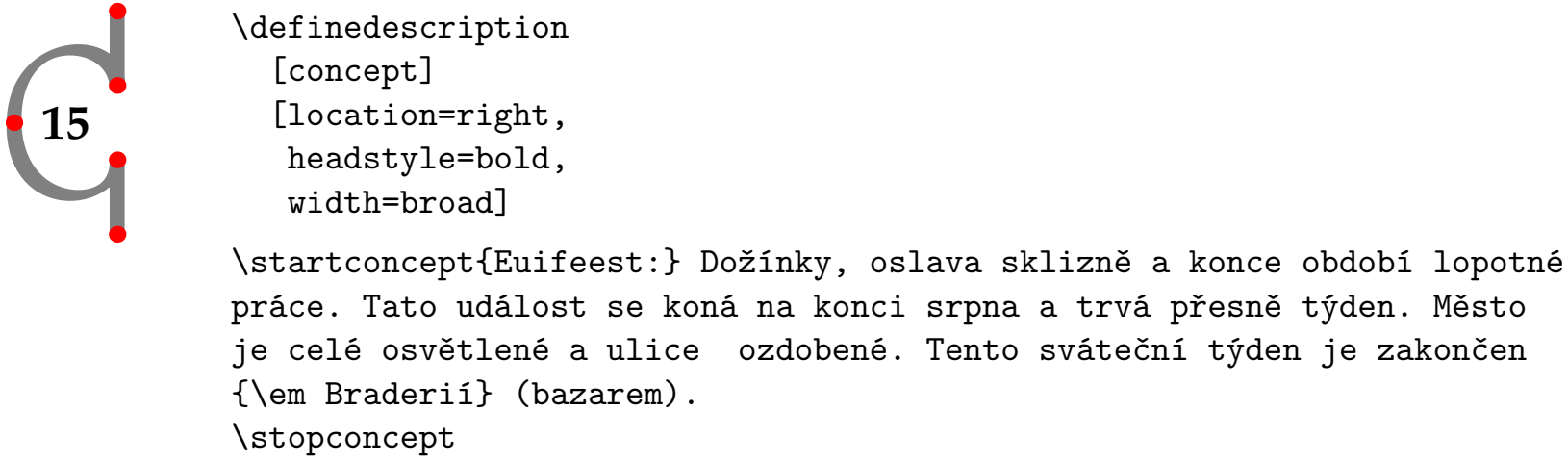

Bude to vypadat následovně:

Dožínky, oslava sklizně a konce období lopotné práce. Tato událost se koná na konci Euifeest: srpna a trvá přesně týden. Město je celé osvětlené a ulice ozdobené. Tento sváteční týden je zakončen Braderií (bazarem).

Formátování je nastaveno druhou hranatou závorkou v \def inedescription [] [] .

Po \definedescription [] [] lze ještě změnit jeho formátování pomocí: 


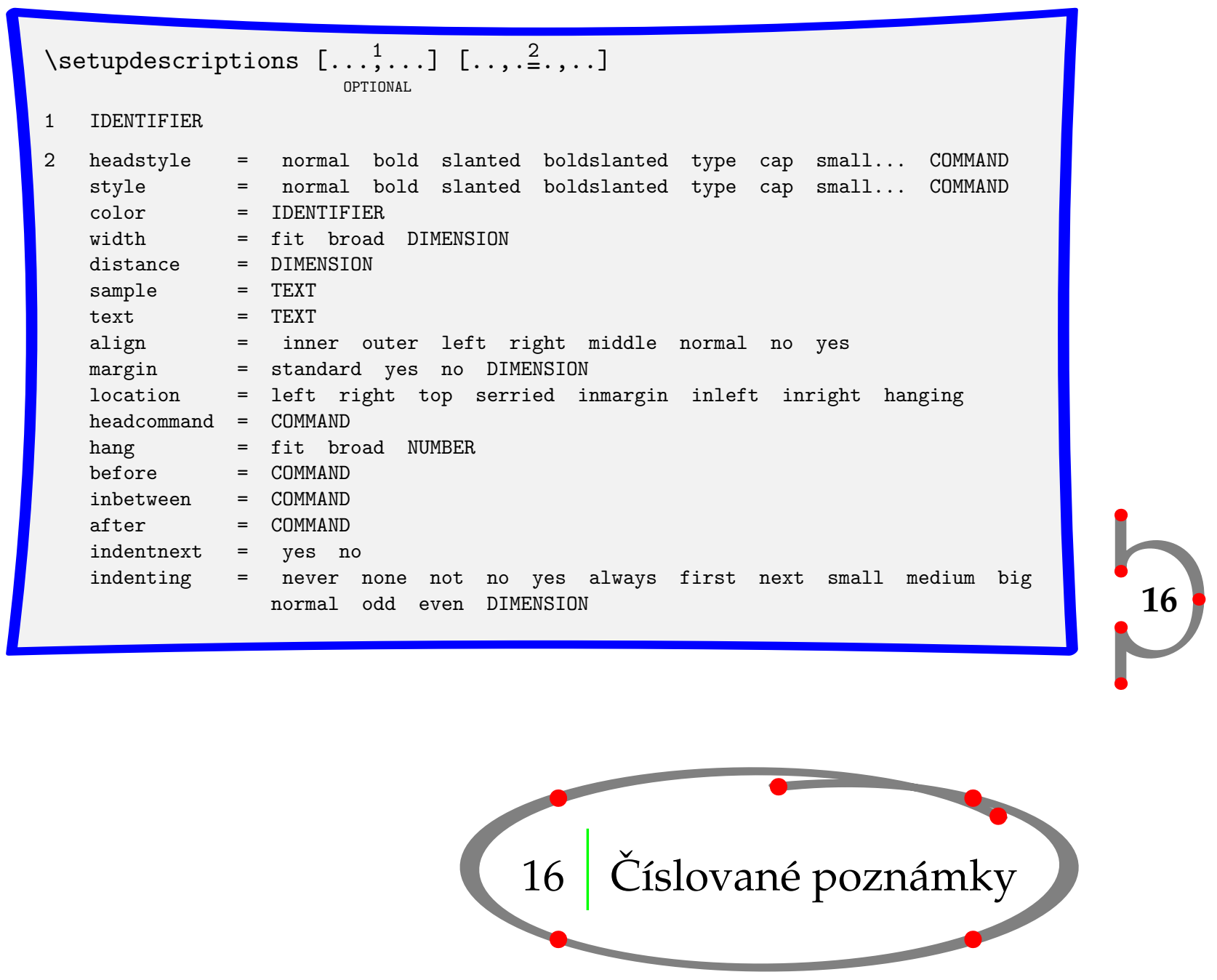

Užitím př́íkazu \defineenumeration můžeme očíslovat části textu, jako poznámky nebo otázky. Pokud chceme takovéto očíslované poznámky v dokumentu vytvořit, použijeme:

\defineenumeration $[\ldots, \ldots] \underset{\text { OPTIONAL }}{[.2 .]}[\ldots \underset{\text { OPTIONAL }}{\stackrel{3}{=} ., \ldots]}$

1 IDENTIFIER

2 IDENTIFIER

3 inherits from \setupenumerations

Např́ílad:
\defineenumeration
[remark]
[location=top, 


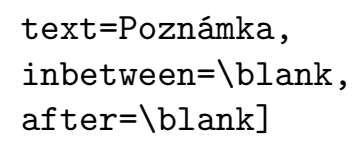

Nyní jsou k dispozici př́kazy \remark, \subremark, \resetremark a \nextremark, takže můžeme psát poznámky typu:

Iremark Na začátku středověku byl Hasselt poutním místem.

Toto \{\em Heilige Stede\} (Posvátné místo) bylo strženo a zničeno

během období reformace. V roce 1930 po 300 letech

bylo \{\em Heilige Stede\} znovu vybudováno a otevřeno.

\subremark Nyní je \{\em Heilige Stede\} opět uzavřeno,

ale jednou ročně se na tomtéž místě koná bohoslužba

pod širým nebem. \par

\section{Poznámka 1}

Na začátku středověku byl Hasselt poutním místem. Toto Heilige Stede (Posvátné místo) bylo strženo a zničeno během období reformace. V roce 1930 po 300 letech bylo Heilige Stede znovu vybudováno a otevřeno.

\section{Poznámka 1.1}

Nyní je Heilige Stede opět uzavřeno, ale jednou ročně se na tomtéž místě koná bohoslužba pod širým nebem.

Pomocí \resetremark nebo \resetsubremark můžeme opět číslovat od začátku. Číslo zvýšíme pomocí \nextremark nebo \nextsubremark. Normálně se poznámky číslují automaticky po kapitolách nebo částech knihy.

Úpravu \defineenumeration si můžeme nastavit takto:

\setupenumerations $\underset{\text { OPTIONAL }}{[\ldots, \ldots]}[\ldots, \stackrel{2}{=} ., \ldots]$

1 IDENTIFIER

2 inherits from \definedescription

Úpravu Poznámky a ,Podpoznámky‘ ve výše uvedeném př́íladu nastavíme pomocí:

\setupenumeration [remark] [headstyle=bold]

Isetupenumeration [subremark] [headstyle=slanted, text=Podpoznámka]

Obsahuje-li poznámka více než jeden odstavec, musíme použít párový př́kaz \startremark ... \stopremark, se kterým lze pracovat po předchozím nadefinování Poznámky užitím \defineenumeration [remark].

Předchozí př́íklad bude vypadat takto:

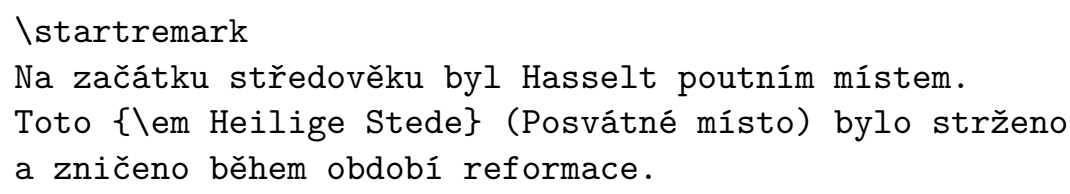


$\mathrm{V}$ roce 1930 po 300 letech bylo \{\em Heilige Stede\}

znovu vybudováno a otevřeno. Nyní je \{\em Heilige Stede\}

opět uzavřeno, ale jednou ročně se na tomtéž

místě koná bohoslužba pod širým nebem.

$\backslash$ stopremark

\section{Poznámka 1}

Na začátku středověku byl Hasselt poutním místem. Toto Heilige Stede (Posvátné místo) bylo strženo a zničeno během období reformace.

V roce 1930 po 300 letech bylo Heilige Stede znovu vybudováno a otevřeno. Nyní je Heilige Stede opět uzavřeno, ale jednou ročně se na tomtéž místě koná bohoslužba pod širým nebem.

Pokud nechceme danou poznámku číslovat, použijeme:

\remark[-] nebo \startremark [-]

Např́klad:

$\backslash$ remark [-]

$\mathrm{Na}$ začátku středověku byl Hasselt poutním místem.

Toto \{\em Heilige Stede\} (Posvátné místo) bylo strženo

a zničeno během období reformace. \par

\section{Poznámka}

Na začátku středověku byl Hasselt poutním místem. Toto Heilige Stede (Posvátné místo) bylo strženo a zničeno během období reformace.

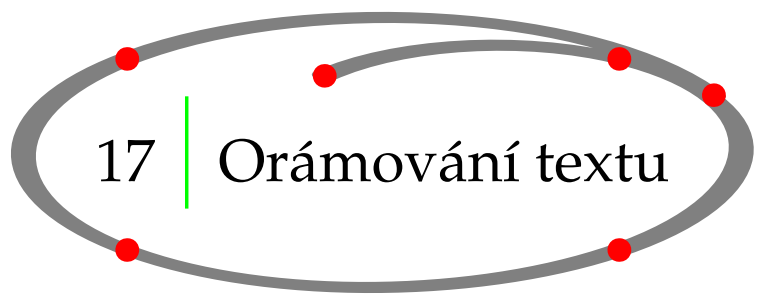

Text můžeme orámovat užitím \framed. Př́ikaz vypadá takto: $\backslash$ framed $[\ldots \underset{\text { OPTINAL }}{. .1} ., \ldots]\{.2 . ?\}$

1 inherits from \setupframed

2 TEXT

Hranaté závorky jsou nepovinné a obsahují nastavení parametrů orámování. Složené závorky obsahují text. Po pravdě řečeno, orámovaný text $\mathrm{v}$ posledním odstavci byl vytvořen př́kazem \inf ramed, který se postará i o správné mezery mezi řádky. 


\section{Orámování textu}

\framed[height=3em, width=fit] \{Hasselt potřebuje více prostoru\}

Tento zápis se zobrazí následujícím způsobem:

Hasselt potřebuje více prostoru

Další příklady \framed a nastavení jeho parametrů jsou ukázány dále. Tentokráte používáme alternativu \inframed.

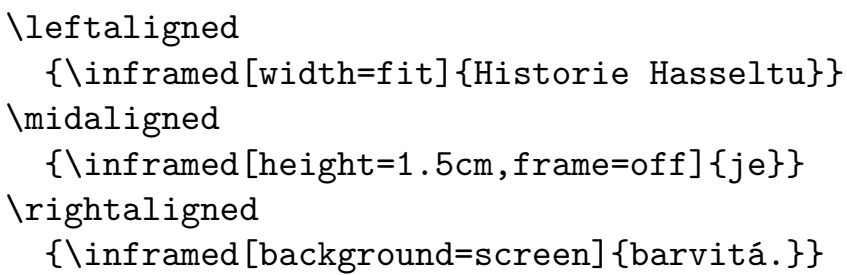

Takový zápis vytvoří:

Historie Hasseltu je

Př́kaz \framed je velmi důmyslný a používá se uvnitř mnoha maker. Syntaxe parametrů orámování je následující: 
$\backslash$ setupframed $[\ldots, . * ., .$.

* height width autowidth

offset

location

option

strut

align

bottom

top

frame

topframe

bottomframe

leftframe

rightframe

frameoffset

framedepth

framecorner

frameradius

framecolor

rulethickness

background

backgroundscreen

backgroundcolor

backgroundoffset

backgrounddepth

backgroundcorner

backgroundradius

depth

corner

radius

empty

foregroundcolor

foregroundstyle
= fit broad DIMENSION

= fit broad fixed local DIMENSION

$=$ yes no force

$=$ none overlay default DIMENSION

= depth hanging high lohi low top middle bottom keep

$=$ none empty

$=$ yes no global local

= inner outer left right middle normal no yes

$=$ COMMAND

$=$ COMMAND

$=$ on off none overlay

$=$ on off

$=$ on off

$=$ on off

$=$ on off

$=$ DIMENSION

$=$ DIMENSION

$=$ round rectangular

= DIMENSION

$=$ IDENTIFIER

= DIMENSION

= screen color none foreground IDENTIFIER

= NUMBER

= IDENTIFIER

= frame DIMENSION

$=$ DIMENSION

$=$ round rectangular

$=$ DIMENSION

$=$ DIMENSION

$=$ round rectangular

$=$ DIMENSION

$=$ yes no

$=$ IDENTIFIER

$=$ normal bold slanted boldslanted type cap small... COMMAND

\section{Orámování odstavce}

Celý odstavec můžeme orámovat pomocí: 


\section{Orámování odstavce}

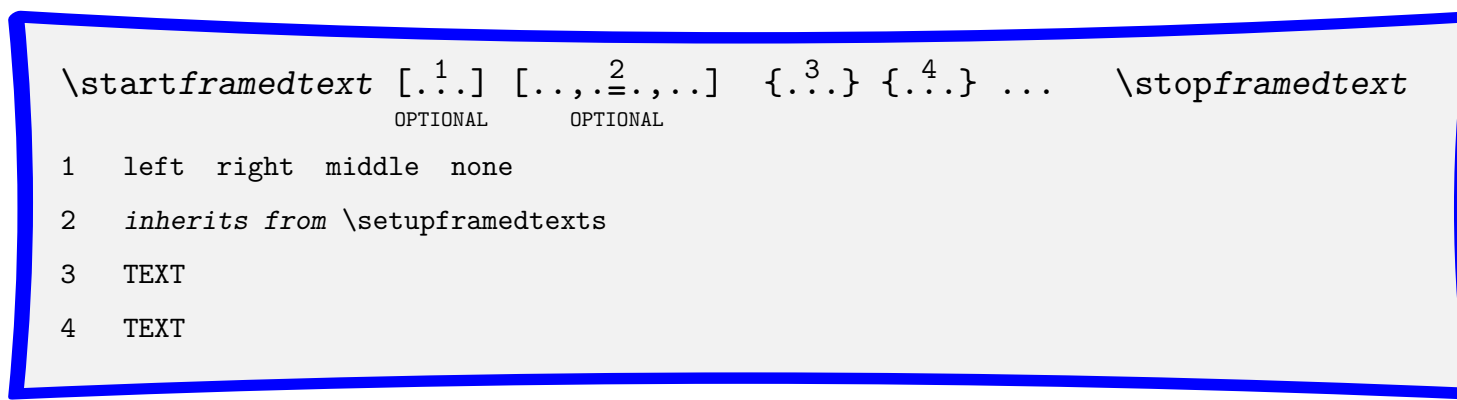

\definefloat [vsuvka]

$\backslash$ placevsuvka [here] [block: bridge] \{Příklad vsuvky.\}

\startframedtext [width=.8\makeupwidth]

Pro město Hasselt bylo velmi důležité mít most

přes řeku Zwarte. Biskup utrechtský dal Hasseltu

svolení k jeho stavbě v roce 1486.

\blank

Ostatní města v okolí se však obávala poplatků, které by bylo nutné platit při přechodu přes tento most, a tak mnoho let bránili jeho stavbě.

\stopframedtext

Tento př́iklad také ukazuje použití příkazu \def inefloat. Více informací k tomuto př́ikazu najdete v sekci 37.2. Příkaz \blank vytvoří prázdný řádek.

Pro město Hasselt bylo velmi důležité mít most přes řeku Zwarte. Biskup utrechtský dal Hasseltu svolení k jeho stavbě v roce 1486.

Ostatní města v okolí se však obávala poplatků, které by bylo nutné platit při přechodu přes tento most, a tak mnoho let bránili jeho stavbě.

\section{Vsuvka 18.1 Př́́klad vsuvky.}

Orámování můžete nastavit pomocí 

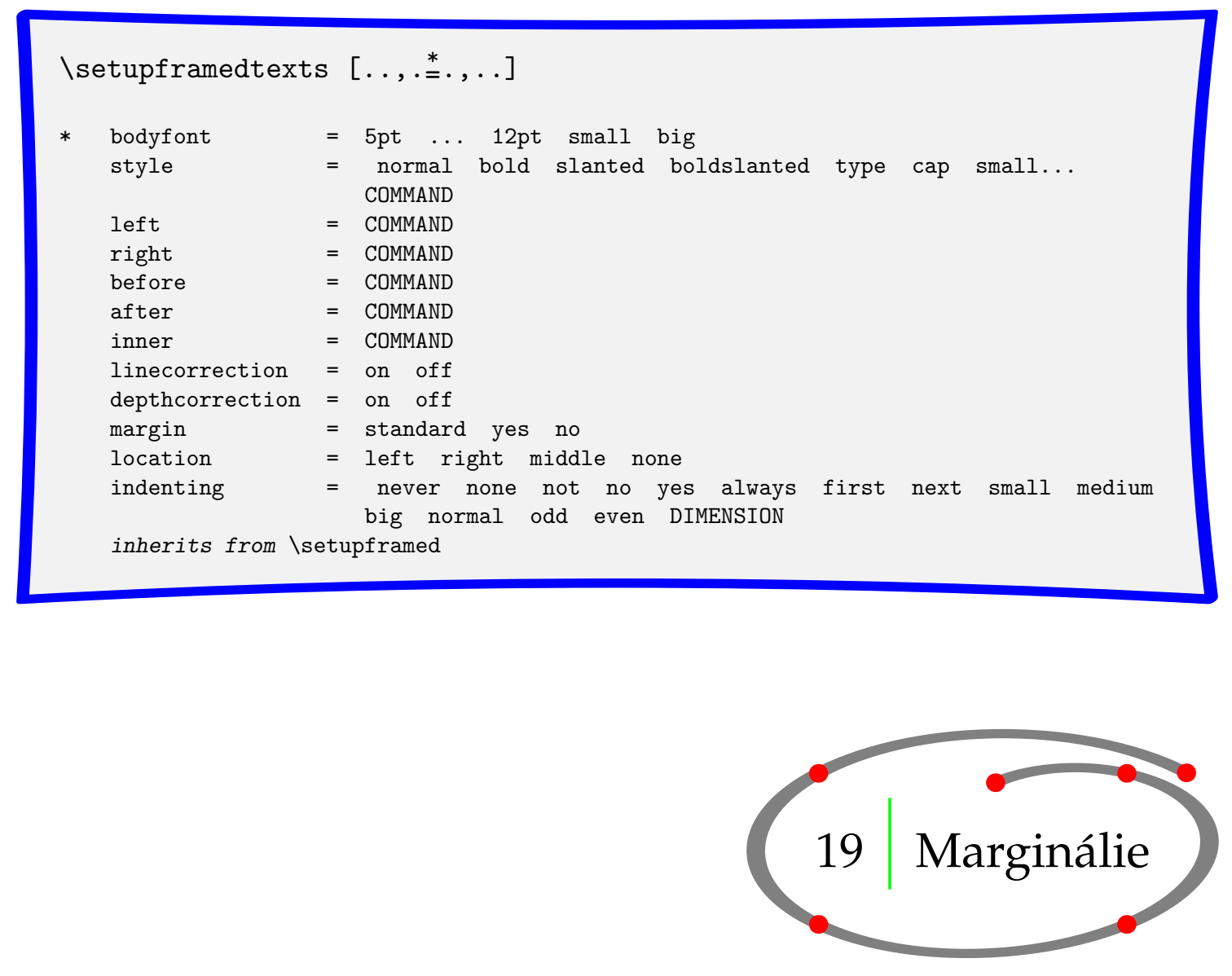

Vložit text do marginálie (okraje stránky) je velmi snadné. Stačí použít \inmargin.

\inmargin [....] [...] $\{.3 .$. OPTIONAL OPTIONAL

$1+-$ low

2 REFERENCE

3 TEXT

Připomeňme si jeden z předcházejících příkladů:

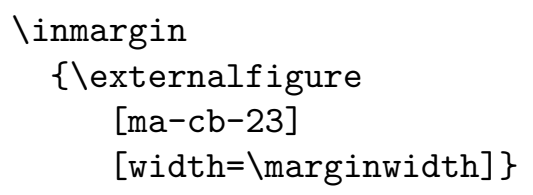

Tato ukázka vysází obrázek do okraje. Jistě si umíme představit, že v některých dokumentech může tento efekt působit velice dobře, ale bud'me opatrní. Okraje jsou většinou velmi úzké a obrázky tak budou vskutku okrajové! 
Několik dalších příkladů je ukázáno v následujícím textu.

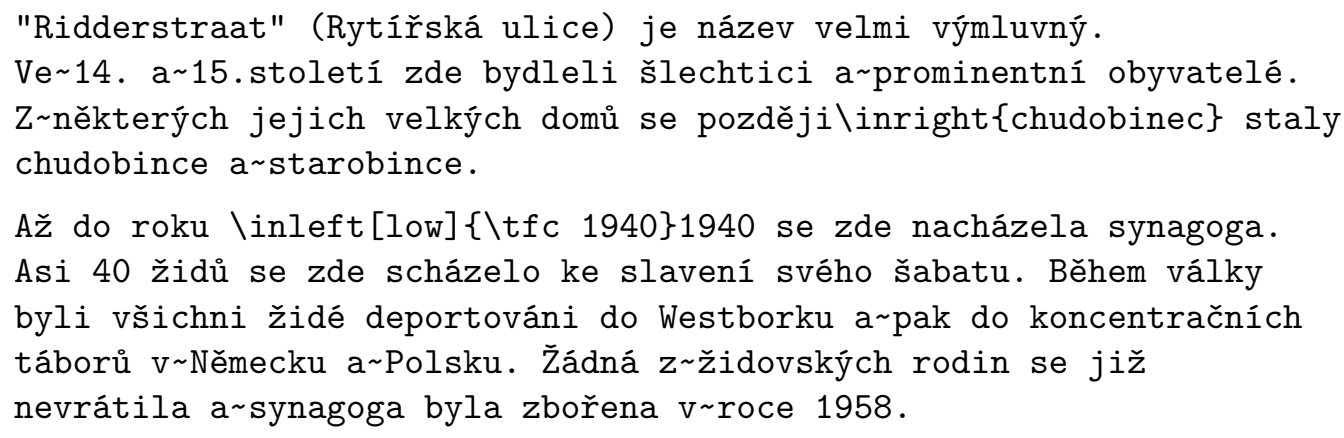

Př́kazy \inmargin, \inleft a \inright plní stejnou funkci. V oboustranně tištěném dokumentu bude př́kaz \inmargin sázet vždy do správného okraje. Dvojité lomítko \\způsobí zalomení řádky. Předchozí př́iklad by tedy vypadal takto:

"Ridderstraat" (Rytiřská ulice) je název velmi výmluvný. Ve 14. a 15.století zde bydleli šlechtici a prominentní obyvatelé. $Z$ některých jejich velkých domů se pozdějistaly chudobince a starobince.

Až do roku 1940 se zde nacházela synagoga. Asi 40 židů se zde scházelo ke slavení svého šabatu. Během války byli všichni židé deportováni do Westborku a pak do koncentračních táborů v Německu a Polsku. Žádná z židovských rodin se již nevrátila a synagoga byla zbořena v roce 1958.

Nastavit text v okraji lze pomocí \setupinmargin.

\setupinmargin $[.1 .].[\ldots, . \stackrel{2}{=} ., \ldots]$ OPTIONAL

1 left right NUMBER

2 location = left right both

style $=$ normal bold slanted boldslanted type cap small... COMMAND

before $=$ COMMAND

after = COMMAND

align = inner outer left right middle normal no yes

line $\quad=$ NUMBER

distance $=$ DIMENSION

separator $=$ TEXT

width $\quad=$ DIMENSION

distance $=$ DIMENSION

stack $\quad=$ yes no

inherits from \setupframed 


\section{Zalamování a číslování stránek}

Zalomení stránky lze vynutit nebo potlačit př́kazem:

$\backslash$ page $[\ldots *, \ldots]$

* yes makeup no preference bigpreference left right disable last quadruple even odd blank empty reset start stop

Parametry se zadávají uvnitř hranatých závorek. Parametry a jejich smysl jsou uvedeny v tabulce 20.1.

\begin{tabular}{ll}
\hline Volba & Význam \\
\hline yes & začátek nové stránky \\
makeup & začátek nové stránky bez plovoucích objektů \\
no & potlačení stránkového zlomu \\
preference & na tomto místě upřednostňujeme novou stránku \\
bigpreference & nová stránka má na tomto místě vysokou prioritu \\
left & následující stránka je levá (sudá) \\
right & následující stránka je pravá (lichá) \\
disable & následující příkazy nemají účinek \\
reset & následující příkazy se provedou \\
empty & vložení prázdné stránky \\
last & vkládání stránek až do dosažení sudého čísla strany \\
quadruple & vkládání stránek až do dosažení násobku čtyřr \\
\hline
\end{tabular}

Tabulka 20.1 Volby př́kazu \page.

Číslování stránek je automatické, ale je možné ručně nastavit číslo stránky př́íkazem:

$\backslash$ page [25]

Někdy je lepší zadat číslo strany relativně, například [+2] nebo [-2].

Umístění čísla stránek na straně závisí na našich preferencích a na typu dokumentu (jednostranný nebo dvojstranný). Číslování stránek se nastavuje př́íkazem: 


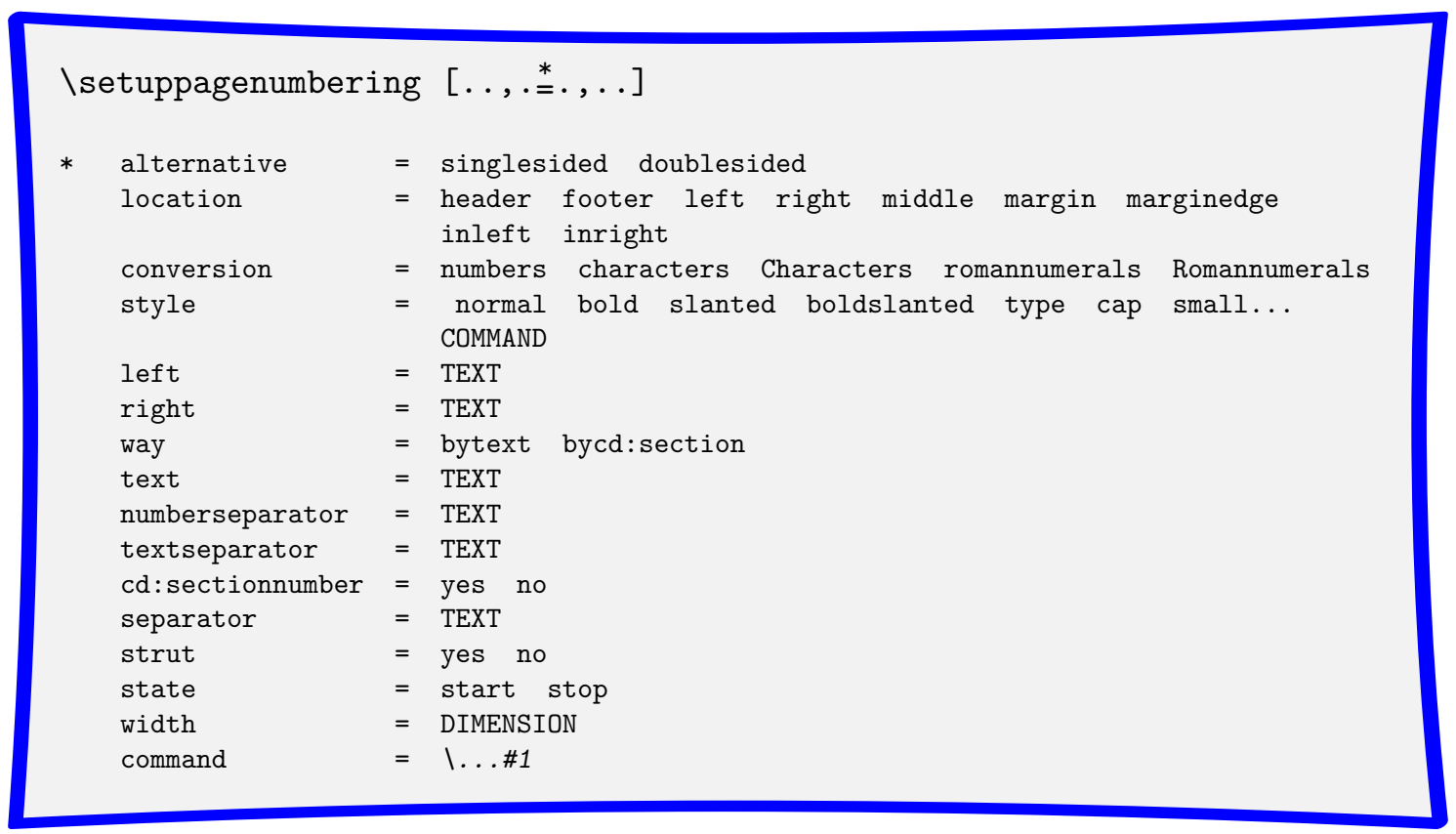

Parametry se umíst'ují do hranatých závorek.

Někdy může být výhodné odložit nějaký materiál až na začátek další strany, tedy po provedení nejbližšího stránkového zlomu. To se provede př́ikazem:

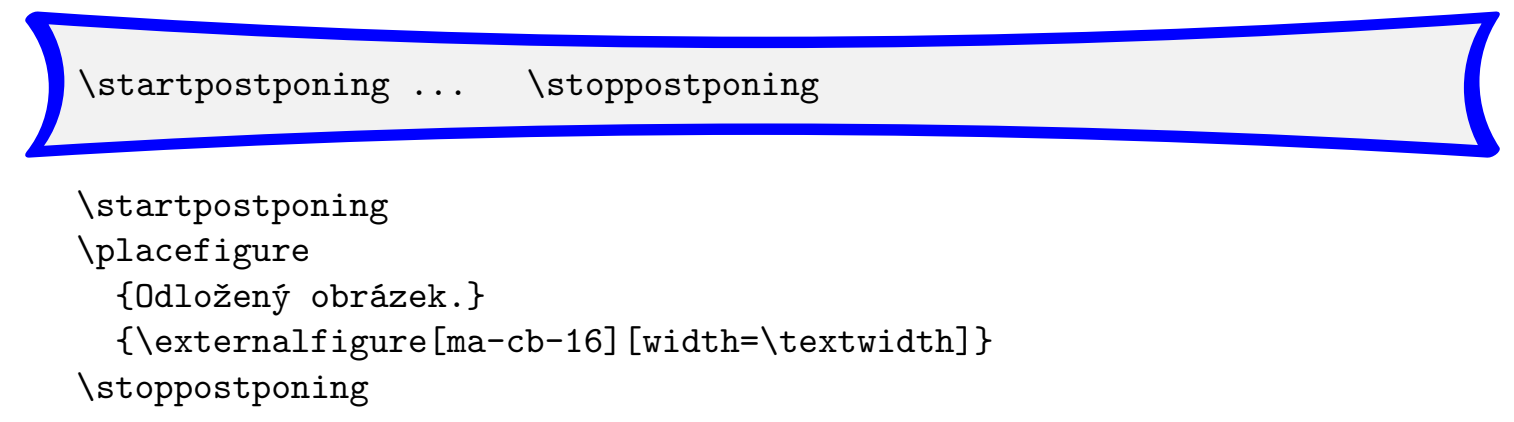

Obrázek bude umístěn ve vrchní části následující strany, aby co nejméně narušoval průběžný text.

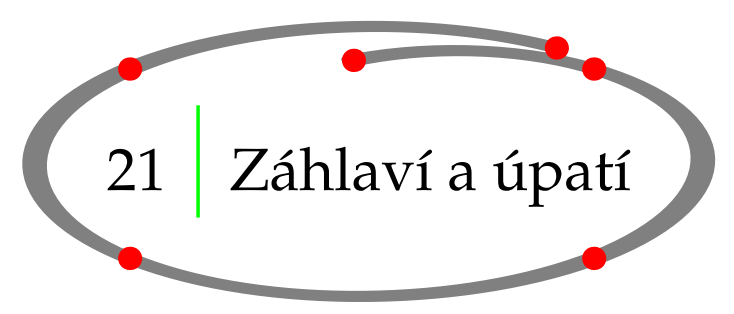

Někdy chceme dokument opatřit záhlavím a úpatím. K tomu se používají následující příkazy: 


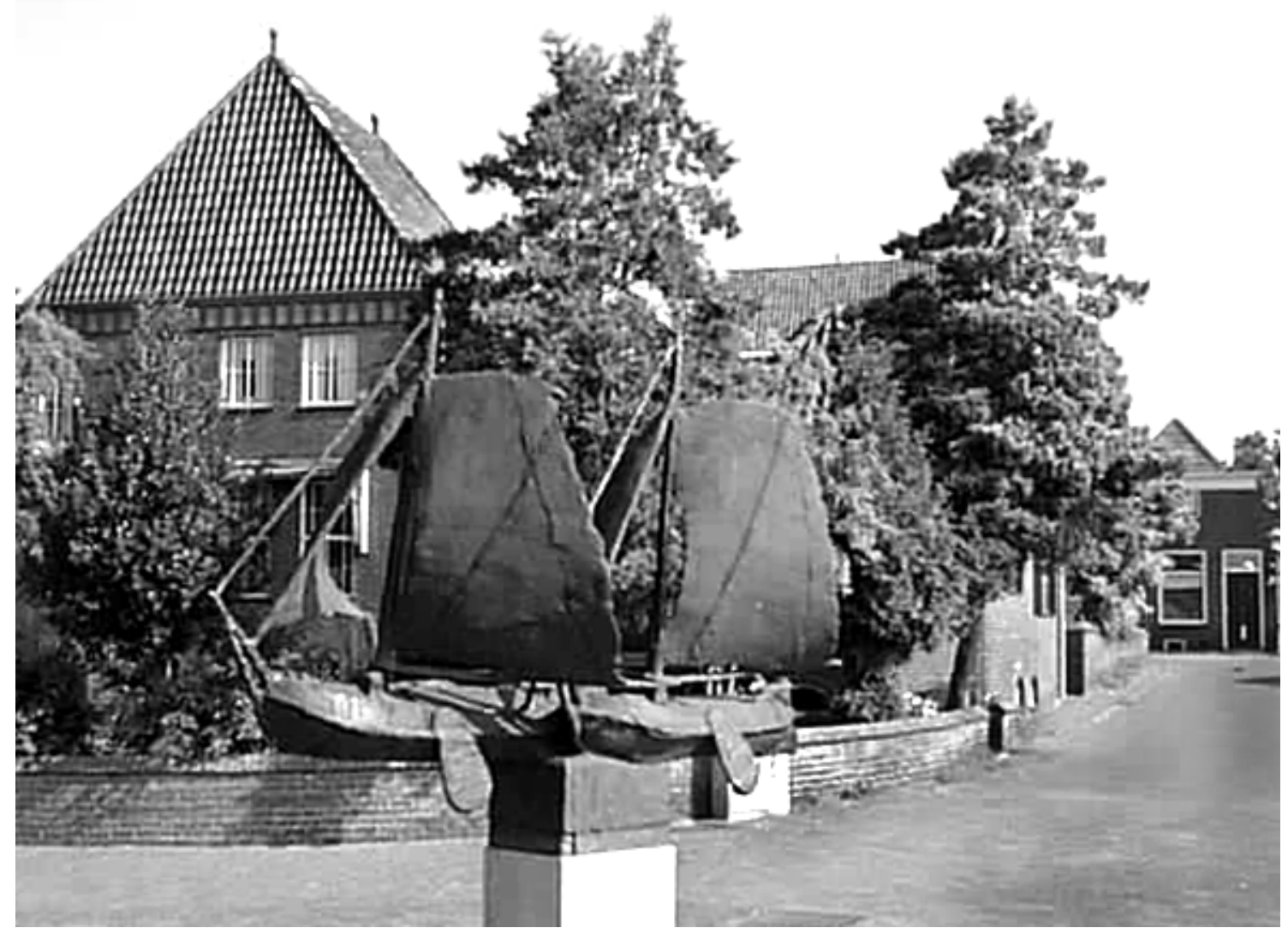

Obrázek 21.1 Odložený obrázek.

Isetupfootertexts $[. .].[.2] \quad.[.3$.

OPTIONAL OPTIONAL OPTIONAL

1 text margin edge

2 TEXT SECTION date MARK pagenumber

3 TEXT SECTION date MARK pagenumber

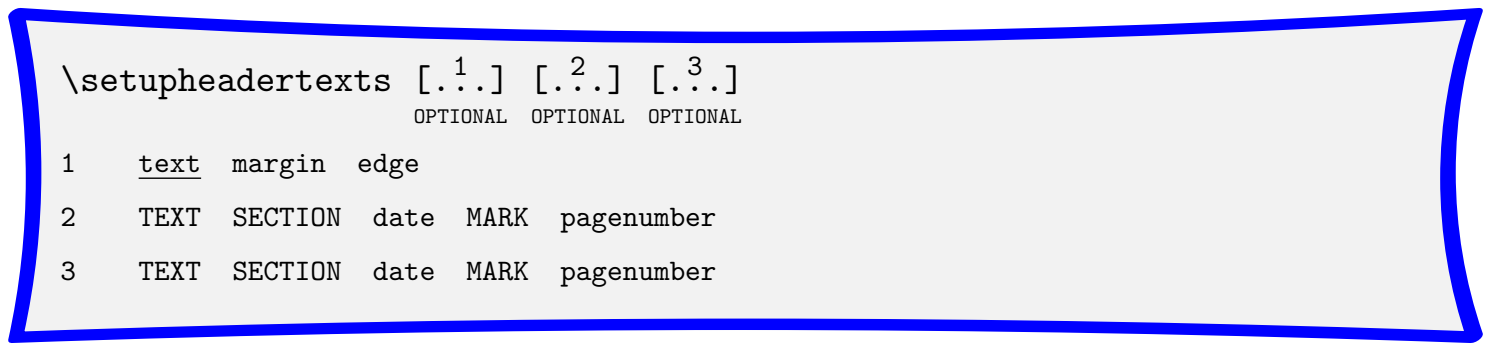

První dvojice závorek udává, kam se má záhlaví nebo úpatí umístit (text, margin=marginálie, edge=vnější okraj, viz obrázek 96). Úpatí a záhlaví jsou určeny druhou a třetí závorkou. V oboustranných dokumentech dodáme čtvrtou a pátou závorku pro nastavení záhlaví/úpatí levých 


\section{Obsah (seznamy)}

a pravých stránek odděleně. Ve většině případů však můžeme tyto poslední dvě závorky vynechat.

\setupfootertexts [Manuál] [section]

V tomto př́ípadě se text Manuál objeví v levém dolním rohu stránky a jméno aktuální kapitoly bude vpravo.

Čáru oddělující záhlaví a úpatí můžeme nastavit pomocí:

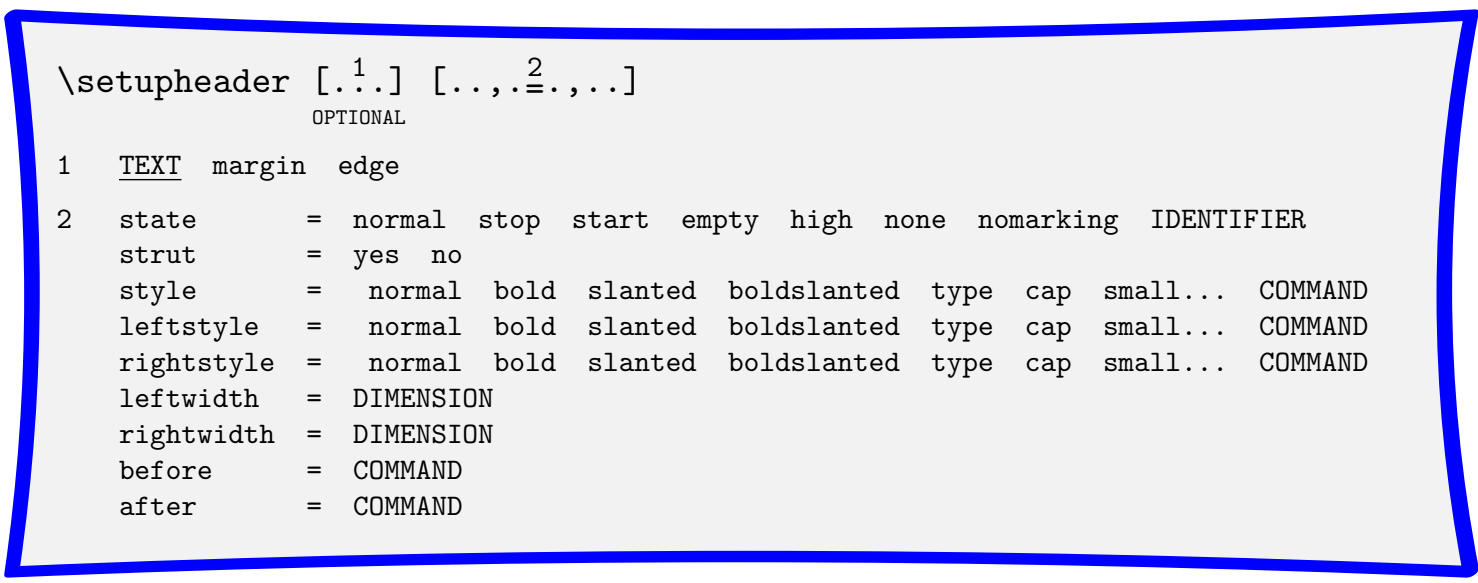

22

Isetupfooter $[. .].[\ldots, . \stackrel{2}{=} ., .$.

OPTIONAL

1 inherits from \setupheader

2 inherits from \setupheader

Pokud chceme záhlaví a úpatí zcela vypustit, napíšeme:

$\backslash$ noheaderandfooterlines

\section{Obsah (seznamy)}

Obsah zahrnuje čísla kapitol, názvy kapitol a čísla stránek; může být rozšířen o sekce, podsekce atd. Obsah se generuje automaticky napsáním:

$\backslash$ placecontent

Jaký obsah se vytvoří, záleží na umístění tohoto příkazu v dokumentu. Na začátku dokumentu se vygeneruje seznam všech kapitol, sekcí atd. Ale umístěním na začátku jednotlivých kapitol, tj.: 


\section{Obsah (seznamy)}

lchapter\{Hasselt $v$ létě\}

$\backslash$ placecontent

$\backslash$ section $\{$ Hasselt $\mathrm{V}$ červenci\}

$\backslash$ section $\{$ Hasselt $v$ srpnu\}

se pouze vytvoří seznam názvů sekcí s odpovídajícím očíslováním a s čísly stránek.

Příkaz \placecontent můžeme použít poté, co nadefinujeme nový seznam pomocí:

$\backslash$ definecombinedlist $[.1 .].[\ldots, \ldots][\ldots, .3 ., \ldots]$

OPTIONAL

1 IDENTIFIER

2 LIST

3 inherits from \setupcombinedlist

Tento př́íkaz spolu s \def inelist nám dovolí nadefinovat vlastní seznam, potřebný ke strukturování celého dokumentu.

Použití tohoto a dalších příbuzných příkazů je ukázáno na následujícím příkladu:

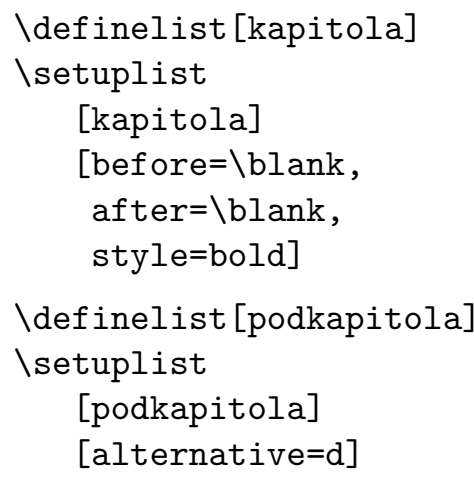

Nyní máme dva seznamy: seznam kapitol a seznam podkapitol. Oba budou sloučeny do jediného obsahu př́ikazem \definecombinedlist.

\definecombinedlist

[obsah]

[kapitola,podkapitola]

[level=subsection]

Po tomto úkonu máme k dispozici dva další př́ikazy: \placeobsah a \completeobsah. Oba způsobí vysázení obsahu, ten druhý ještě přidá nadpis ,Obsah'.

Vzhled seznamu lze nastavit parametrem alternative.

Seznamy se nastavují pomocí: 
Obsah (seznamy)

\begin{tabular}{cl}
\hline Nastavení & Formátování \\
\hline a & číslo - název - číslo stránky \\
b & číslo - název - mezery - číslo stránky \\
c & číslo - název - tečky - číslo stránky \\
d & číslo - název - číslo stránky (v odstavci) \\
e & rezervováno pro interaktivní účely \\
f & rezervováno pro interaktivní účely \\
\hline
\end{tabular}

Tabulka 22.1 Nastavení formátování seznamů. 
Obsah (seznamy)

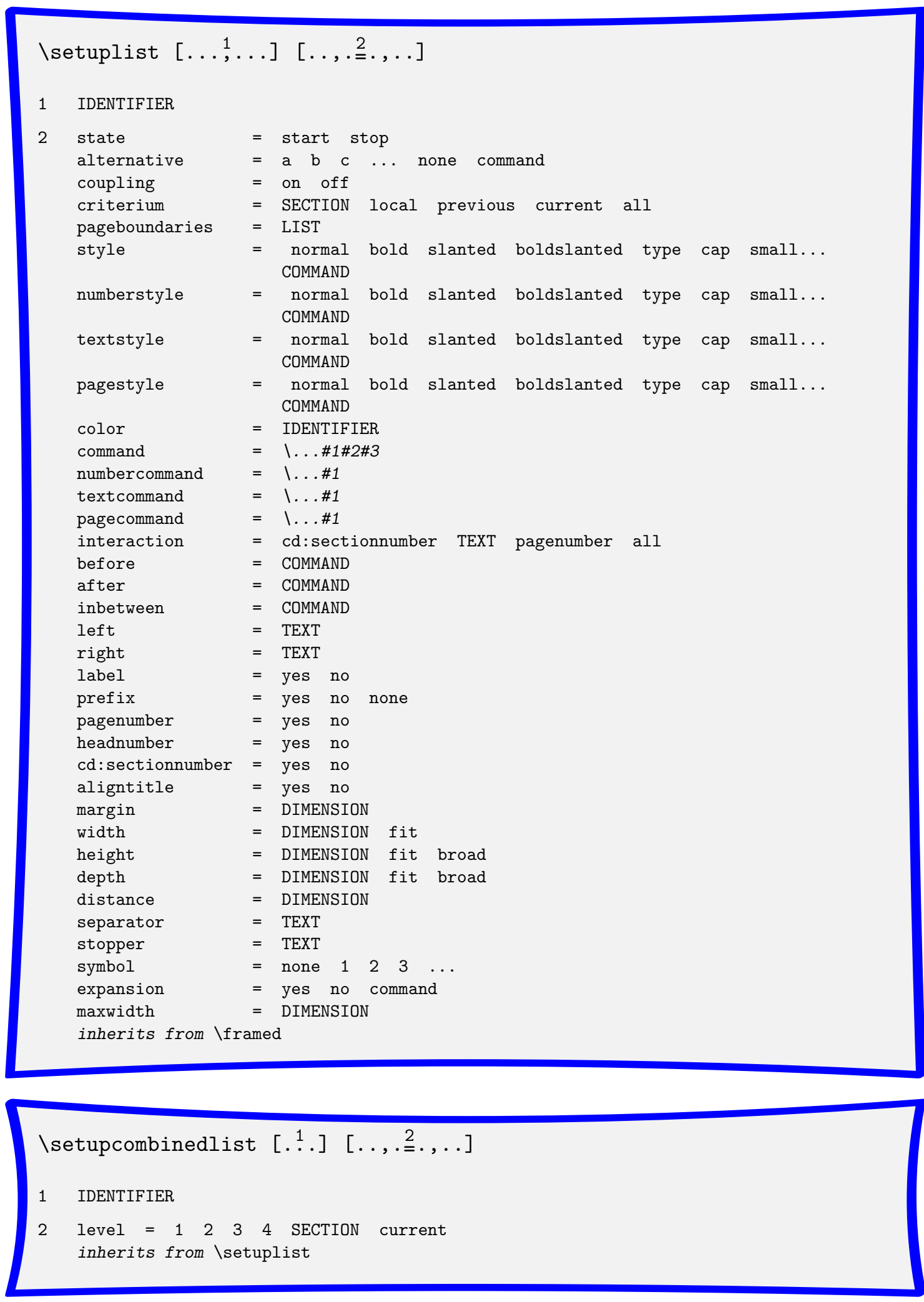

Pokud chceme změnit vzhled generovaného obsahu, musíme pamatovat na to, že je to seznam. 


\section{Obsah (seznamy)}

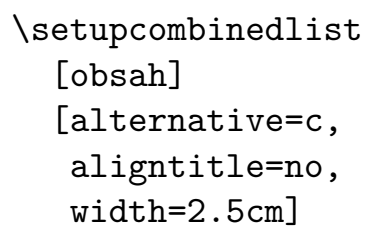

Od této chvíle se bude formátování obsahu lišit od jeho standardního nastavení.

Seznamy se vyvolávají a umíst'ují pomocí:

$\backslash$ placelist $[\ldots, \ldots][\ldots, . \stackrel{2}{=}, \ldots]$

OPTIONAL

1 IDENTIFIER

2 inherits from \setuplist

Chceme-li tedy pouze část obsahu, napíšeme:

$\backslash$ placecontent [level=section]

nebo

\completecontent [level=section]

a zobrazí se pouze kapitoly a sekce. To se může hodit, pokud máme složitý a strukturovaný obsah, který má spoustu pod pod a pod odstavců, které v celkovém obsahu nechceme vypisovat.

Dlouhý seznam nebo obsah se nevejde na jednu stránku. Potřebujeme-li ve vhodném místě vynutit přechod na novou stránku, napíšeme:

Icompletecontent $[2.2,8.5,12.3 .3]$

Zalomení stránky se objeví po sekci 2.2 a 8.5 a podsekci 12.3.3.

V některých př́padech chceme v automaticky generovaném seznamu napsat vlastní text. Toho dosáhneme pomocí:

\writetolist $[. .1].\{.2\}.\{.3$.

1 SECTION IDENTIFIER

2 TEXT

$3 \quad$ TEXT

$\backslash$ writebetweenlist [. ‥] $\{. \stackrel{2}{.}\}$

1 SECTION IDENTIFIER

2 TEXT

Např́klad, chceme-li udělat poznámku v obsahu po sekci nazvané Hotely v Hasseltu, napíšeme: 


\section{Rejstř́ky}
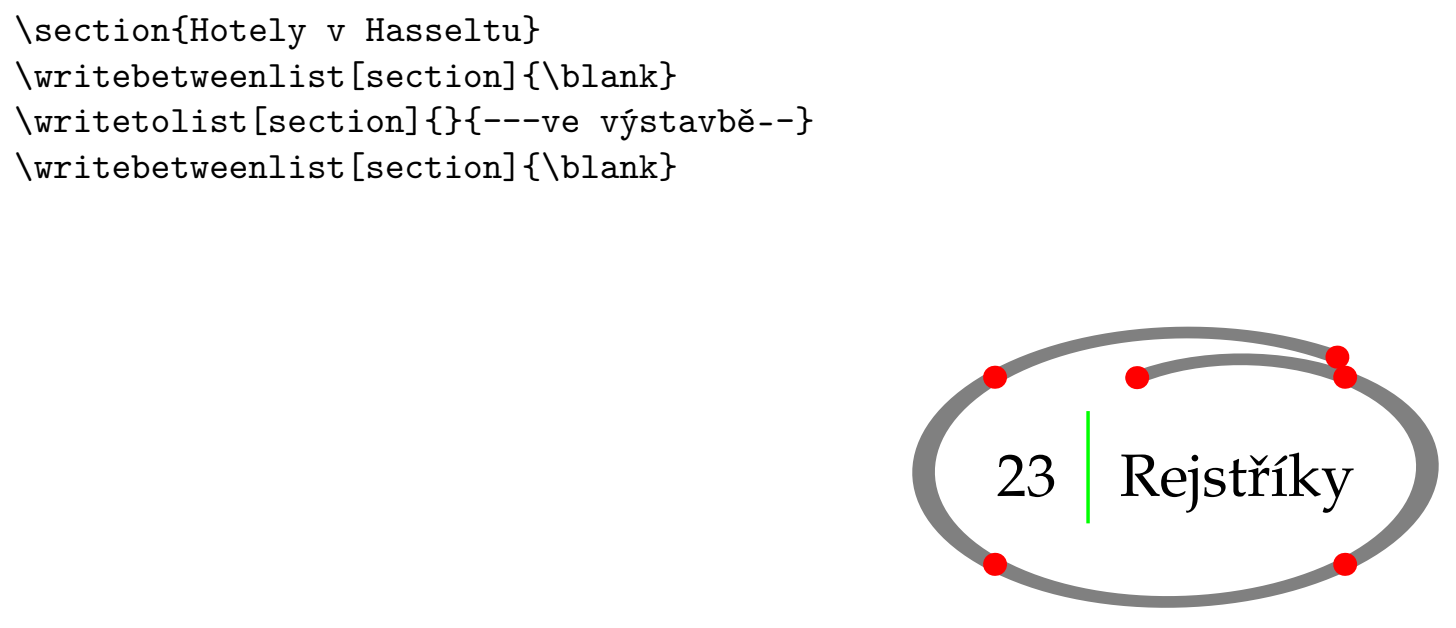

V CONTEXTu je možné vytvořit jeden nebo více rejstříkủ. Implicitně je k dispozici př́kaz \index. Jestliže chceme do rejstř́ku přidat nějaké slovo, napíšeme např́ílad:

$\backslash$ index $\{$ radnice $\}$

Výraz radnice se objeví jako heslo rejstříku. Rejstř́ik je pomocným programem seřazen podle abecedy. Pokud je některé heslo třeba zatřídit mimo běžné abecední pořadí, například v př́ípadě symbolu, musí být doplněno o další třídící informaci:

$\backslash$ index [minus] $\{\$-\$\}$

Někdy máme pod- nebo podpodhesla. Ty se zadávají následujícím způsobem:

$\backslash$ index\{radnice+poloha\}

$\backslash$ index radnice+architektura\}

Rejstř́k vygenerujeme př́íkazem

$\backslash$ placeindex

nebo

\completeindex

Př́kaz \index je v CONTEXTu předdefinovaný, ale samozřejmě můžeme také definovat své vlastní rejstř́iky:

\defineregister $[. \stackrel{1}{.}][.2$.

1 SINGULAR NAME

2 PLURAL NAME

Chceme-li např́klad vytvořit rejstř́k ulic v Hasseltu, můžeme napsat:

\defineregister [ulice] [ulice]

Nyní je k dispozici nový př́kaz pro tvorbu rejstříku \ulice. Heslem tohoto nového rejstř́iku může být třeba \ulice\{Ridderstraat\}. Samotný seznam ulic nyní vytvoříme použitím př́íkazů: 


\section{Synonyma}

$\backslash$ placeulice

Icompleteulice

Vzhled rejstř́ků můžeme měnit příkazem:

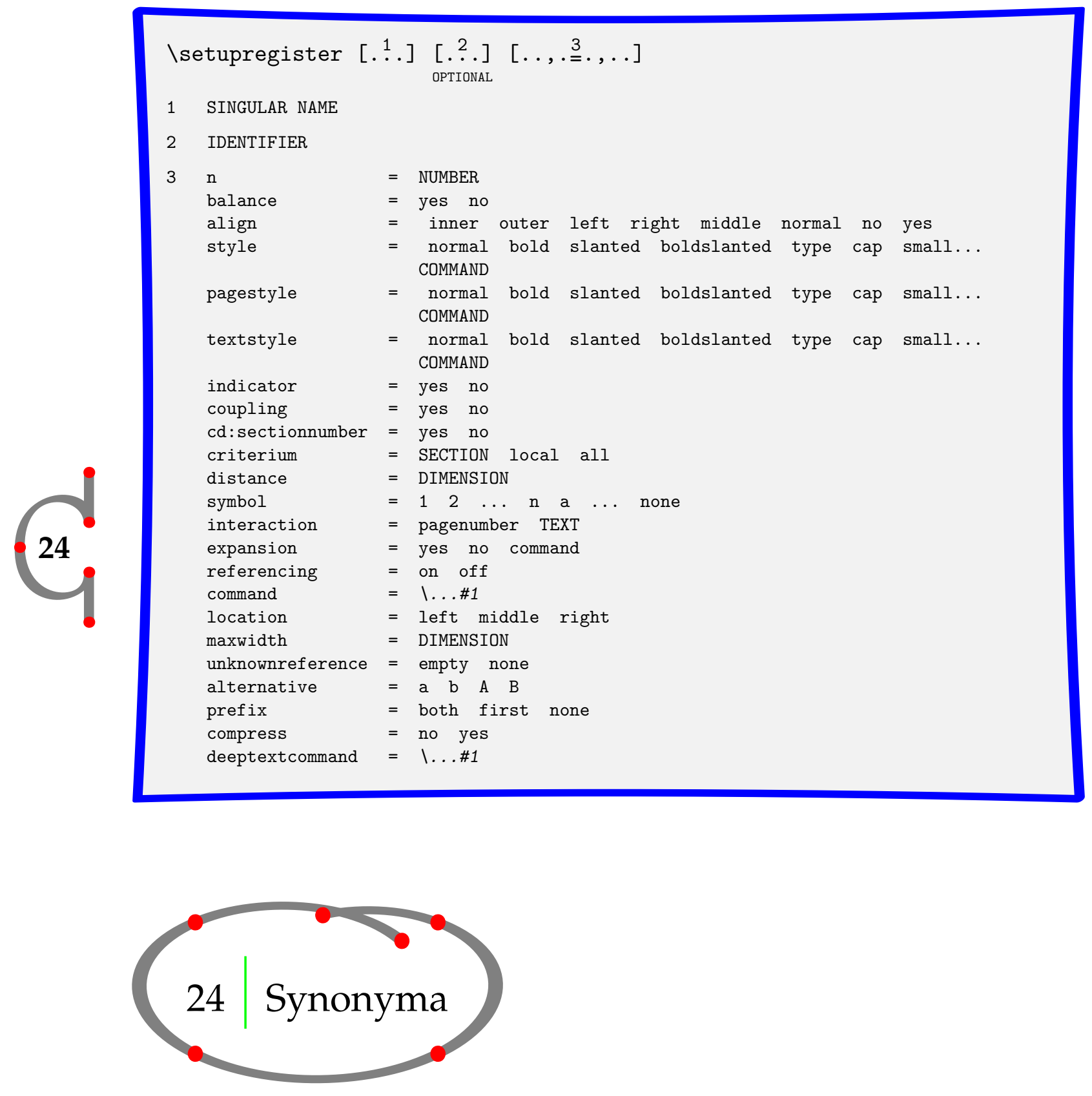

V mnoha případech chtějí autoři používat určitá slova shodně v celém dokumentu. $\mathrm{K}$ dosažení jednotnosti je k dispozici následující př́ḱkaz: 
\definesynonyms [....] [..2.] [..3..] [....]

1 SINGULAR NAME

2 PLURAL NAME

3 COMMAND

4 COMMAND

První dvojice hranatých závorek obsahuje tvar synonyma v jednotném čísle a druhá dvojice obsahuje tvar množného čísla. Třetí dvojice hranatých závorek obsahuje povel.

Např́klad povel \abbreviation (zkratka) je definován následovně:

$\backslash$ definesynonyms [abbreviation] [abbreviations] [\infull]

\setupsynonyms [style=cap]

Nyní je k dispozici př́kaz \abbreviation a můžeme jím definovat své vlastní zkratky:

\abbreviation\{ANWB\} \{Holandská automobilová asociace\}

labbreviation\{VVV\}\{Úr̆ad turistických informací\}

\abbreviation $\{\mathrm{NS}\}\{$ Holandské dráhy\}

Jestliže napíšeme:

Holandský \VVV\( (infull\{VVV\}) nám může poskytnout turistické informace o Hasseltu.

Dostaneme něco jako:

Holandský VVv (Úřad turistických informací) nám může poskytnout turistické informace o Hasseltu.

Seznam synonym a zkratek je nejlepší definovat v deklarační oblasti našeho vstupního souboru $z$ důvodu jeho jednoduché údržby. Tento typ informace můžeme také uložit do externího souboru (např. abbrev.tex) a tento načíst př́ḱkazem:

\input abbrev.tex

Když chcete do vašeho dokumentu umístit seznam zkratek, můžete napsat:

$\backslash$ placelistof abbreviations

nebo

\completelistofabbreviations

Vytvoří se tak úplný abecedně uspořádaný seznam zkratek a jejich významů.

Sazba synonym se dá ovlivnit př́íkazem \setupsynonyms. 
\setupsynonyms $[. \stackrel{1}{.}][\ldots, .2 ., .$.

1 IDENTIFIER

2 textstyle $=$ normal bold slanted boldslanted type cap small... COMMAND synonymstyle $=$ normal bold slanted boldslanted type cap small... COMMAND location $\quad=$ left right top serried inmargin inleft inright width $\quad$ DIMENSION

state $\quad=$ start stop

criterium $\quad=$ all used

conversion $=$ yes no

expansion $=$ yes no command

command $\quad=1 \ldots \# 1 \# 2 \# 3$

Další aplikace synonym je popsána v kapitole 9.

\section{Kř́žové odkazy}

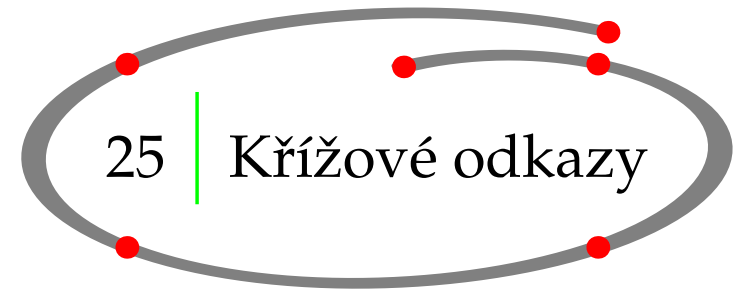

Na vytvoření křižového odkazu z jednoho místa dokumentu na druhé použijeme př́ikaz:

$\backslash$ in $\{. \stackrel{1}{.}\}\{.2 .\}.[. .3$.

$1 \quad$ TEXT

2 TEXT

3 REFERENCE

Složené závorky mohou obsahovat text, který má být vysázen před nebo za odkazem. To je výhodné pro zvětšení klikatelné oblasti v interaktivních dokumentech. Hranaté závorky pak nesou referenční jméno. Když napíšeme název kapitoly následujícím způsobem

Ichapter [hotel] \{Hotely v Hasseltu\}

tak se na tuto kapitolu můžeme odkázat povelem

V \in\{kapitole\} [hotel]

Po zpracování dostaneme číslo kapitoly a odkaz vypadá například takto: $v$ kapitole 23. Př́íkaz \in můžeme použít s referenčním jménem libovolného textového prvku, například kapitoly, sekce, obrázku, tabulky, vzorce, apod.

Další př́klad: 
V Hasseltu můžeme dělat spoustu věcí:

\startitemize [n,packed]

\item plavat,

\item plachtit,

\item[tramp] trampovat,

\item jezdit na kole.

\stopitemize

\in\{Činnost\}[tramp] popsaná na \at\{straně\}[tramp] je velmi namáhavá.

Bude to vypadat takto:

V Hasseltu můžeme dělat spoustu věcí:

1. plavat,

2. plachtit,

3. trampovat,

4. jezdit na kole.

Činnost 3 popsaná na straně 75 je velmi namáhavá.

Jak můžeme vidět, je také možné vytvořit odkaz na stránku. To se dělá přríkazem:

\at $\{. \stackrel{1}{.}\}.\{.2\} \quad.[. \stackrel{3}{.}]$

1 TEXT

2 TEXT

3 REFERENCE

Tento příkaz lze kombinovat s povely:

\pagereference $[. *$. .

* REFERENCE

a

\textreference $[.1] \quad.\{.2$.

1 REFERENCE

2 TEXT

Když se chceme odkázat na kapitolu Hotely v Hasseltu, můžeme napsat:

V \in\{kapitole\}[hotel] na \at\{straně\}[hotel] nalezneme úplný přehled možností ubytování $v \sim \backslash p a g e r e f e r e n c e[b y d l e n i] H a s s e l t u$. 
Při zpracování zdrojového souboru bude vygenerováno číslo kapitoly a číslo strany. Na jiném místě dokumentu se můžeme odkázat na bydleni takto: na \at\{straně\} [bydleni].

Můžeme rovněž definovat několik návěští oddělených čárkami.

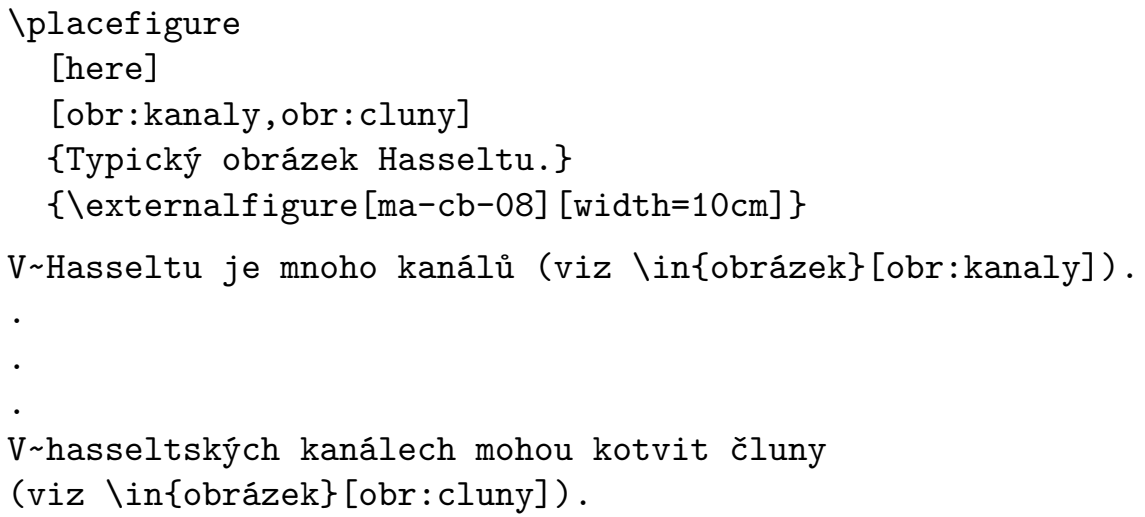

Výsledek může vypadat následovně:
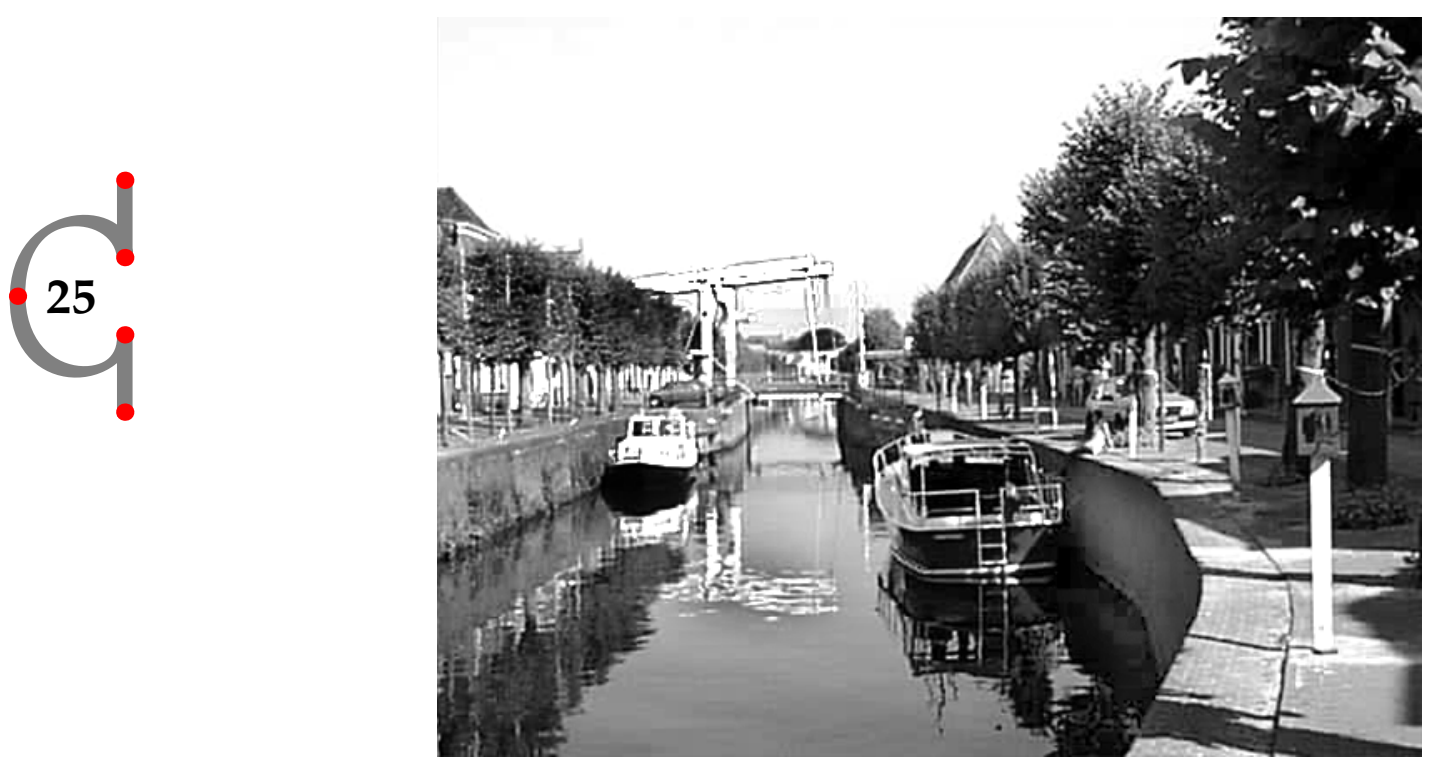

Obrázek 25.1 Typický obrázek Hasseltu.

V Hasseltu je mnoho kanálů (viz obrázek 25.1). . . V hasseltských kanálech mohou kotvit čluny (viz obrázek 25.1). 


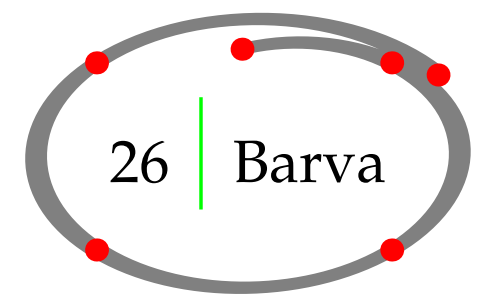

Text může být sázen barevně.

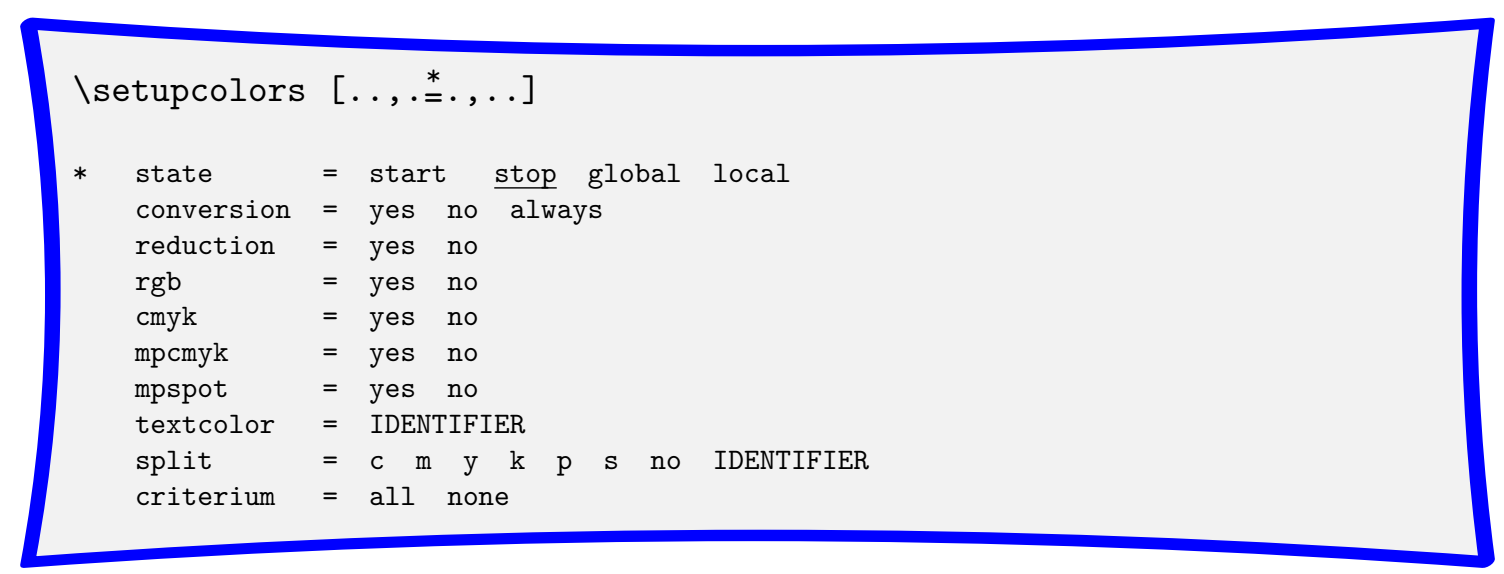

Používání barev se musí zapnout povelem:

\setupcolors [state=start]

Nyní máme k dispozici základní barvy (červenou - red, zelenou - green a modrou - blue).

Istartcolor [red]

Hasselt je velice \color[green] \{barevné\} město.

Istopcolor

Hasselt je velice barevné město.

Při použití černobílého tisku uvidíme jenom šedé odstíny. V elektronickém dokumentu barvy dopadnou podle očekávání.

Můžete také definovat své vlastní barvy prŕíkazem: 
\definecolor $[. .].[\ldots, . \stackrel{2}{=}, \ldots]$

1 IDENTIFIER

$2 r=$ TEXT

$\mathrm{g}=\mathrm{TEXT}$

$\mathrm{b}=\mathrm{TEXT}$

$c=\mathrm{TEXT}$

$\mathrm{m}=\mathrm{TEXT}$

$\mathrm{y}=\mathrm{TEXT}$

$\mathrm{k}=\mathrm{TEXT}$

$\mathrm{s}=\mathrm{TEXT}$

$\mathrm{h}=\mathrm{TEXT}$

$\mathrm{t}=\mathrm{TEXT}$

$\mathrm{a}=\mathrm{TEXT}$

$\mathrm{p}=\mathrm{TEXT}$

$\mathrm{e}=\mathrm{TEXT}$

Např́klad:

\definecolor [temneruda] $\quad[\mathrm{r}=.5, \mathrm{~g}=.0, \mathrm{~b}=.0]$

\definecolor [tmavezelena] $[\mathrm{r}=.0, \mathrm{~g}=.5, \mathrm{~b}=.0]$

Nyní jsou k dispozici barvy temneruda a tmavezelena.

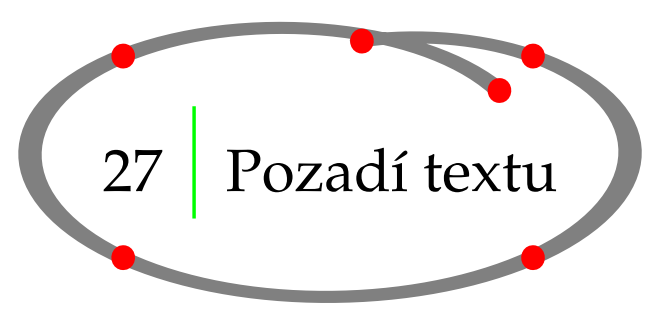

Ke zvýraznění kapitoly nebo několika odstavců můžeme použít pozadí. Takový text se vloží do prostředí

Istarttextbackground ... \stoptextbackground

Použití ilustruje tento př́klad:

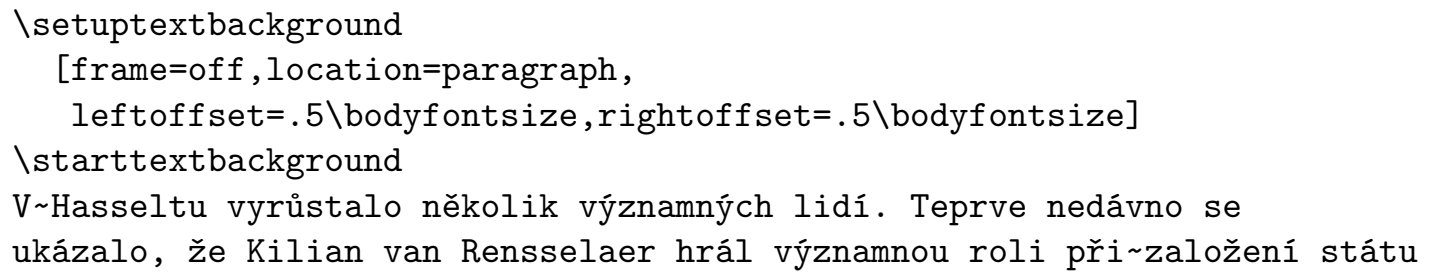




\section{Pozadí stránky}

New York.

\stoptextbackground

Výsledkem je:

V Hasseltu vyrůstalo několik významných lidí. Teprve nedávno se ukázalo, že Kilian van Rensselaer hrál významnou roli při založení státu New York.

Pozadí může zabírat několik stránek. Pomocí

\setuptextbackground $[\ldots, . * *, \ldots]$

* leftoffset $=$ DIMENSION

rightoffset $=$ DIMENSION

topoffset $\quad=$ DIMENSION

bottomoffset $=$ DIMENSION

before $\quad=$ COMMAND

after $\quad=$ COMMAND

state $=\underline{\text { start }}$ stop

location = text paragraph none

alternative $=\underline{0} 12$

inherits from \setupframed

lze ovlivnit jeho formátování.

\section{Pozadí stránky}

Pozadí stránky může být nastaveno pomocí:

\setupbackgrounds $\underset{\text { OPTIONAL }}{[.1}] \underset{\text { OPTIONAL }}{[., \ldots]}[\ldots, .3, \ldots]$

1 top header TEXT footer bottom page paper leftpage rightpage

2 leftedge leftmargin TEXT rightmargin rightedge

3 state $=$ start stop cd:repeat

inherits from \setupframed

První dvě hranaté závorky definují část plochy stránky, které chceme nastavit pozadí. Poslední závorka obsahuje jeho parametry. 


\section{Zarovnání}

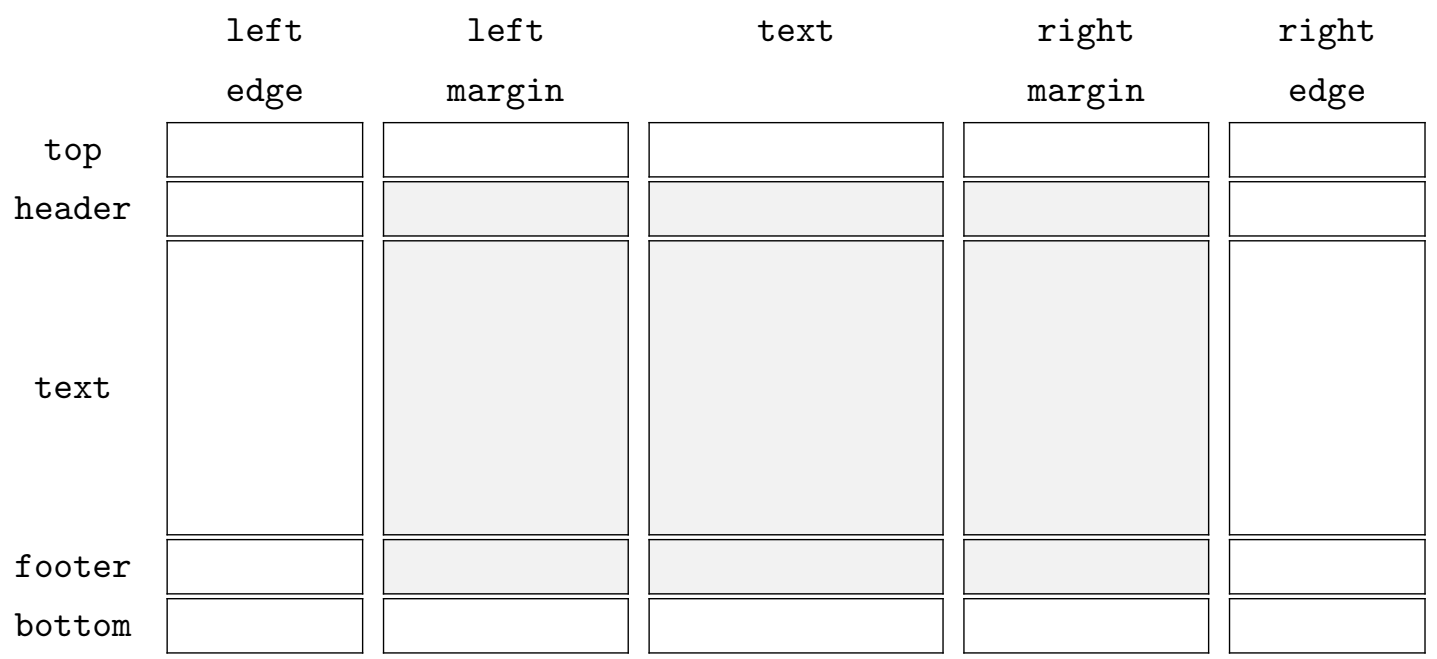

Obrázek 28.1 Plochy stránky použitelné $\mathrm{v} \backslash$ setupbackgrounds.

Pokud např. chcete mít šedé pozadí jako na obrázku 28.1, napíšeme:

$\backslash$ setupbackgrounds

[header, text, footer]

[leftmargin, text, rightmargin]

[background=screen]

Horizontální a vertikální zarovnání textu se nastavuje pomocí

\setupalign $\left[\ldots^{*}.\right]$

* width left right middle inner outer wide broad height bottom line reset hanging nothanging hyphenated nothyphenated

Pro zarovnání jedné řádky stačí uvést:

$\backslash$ rightaligned \{\}

$\backslash$ leftaligned \{\}

$\backslash$ midaligned \{\}

Např. 
Interaktivní mód v elektronických dokumentech

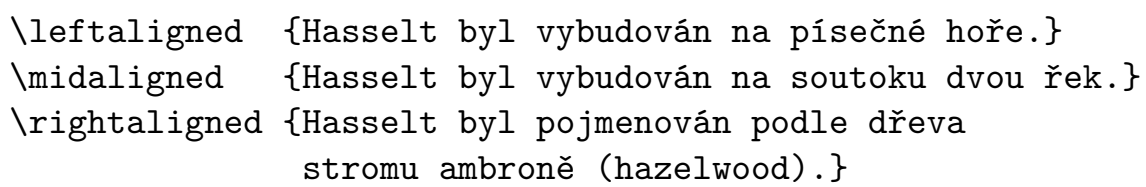

Po zpracování bude tento př́ílad vypadat takto:

Hasselt byl vybudován na písečné hoře.

Hasselt byl vybudován na soutoku dvou řek.

Hasselt byl pojmenován podle dřeva stromu ambroně (hazelwood).

K zarovnání odstavce se použije:

\startalignment $[\ldots] \ldots$... \stopalignment

* inherits from \setupalign

Zarovnání můžeme upřesnit zadáním směru (direction) a tolerance pružných výplňků (tolerance). Směr může být vertikální (vertical) a horizontální (horizontal). Tolerance je standardně velmi přísná (verystrict). Při sazbě do užších sloupců je užitečné povolit schovívavější přístup k zalamování odstavce (tolerant nebo verytolerant). Pro sazbu tohoto manuálu je tolerance nastavena takto:

\setuptolerance [horizontal, verystrict]

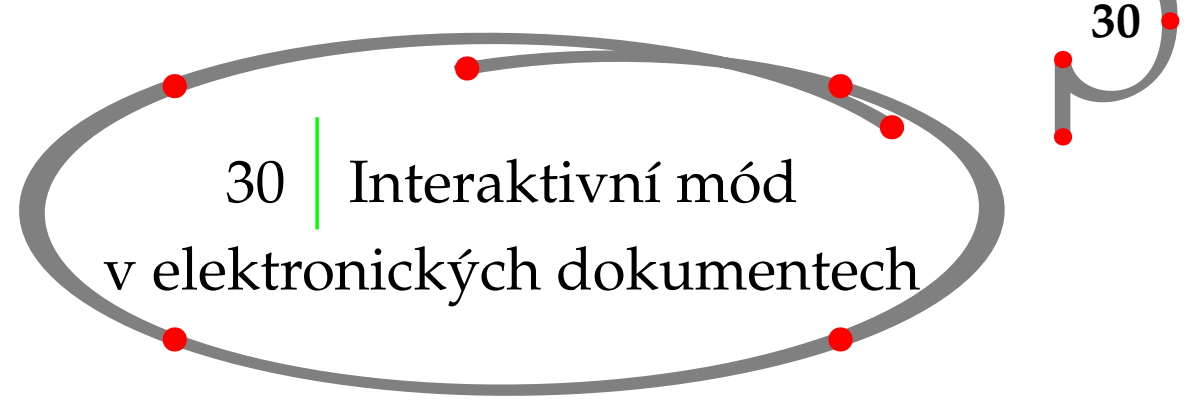

\section{1 Úvod}

Dokumenty dnes mohou být zpř́stupňovány elektronicky prostřednictvím obrazovky počítače.

Po kliknutí myší na určitou plochu interaktivního dokumentu, se nám zobrazí jeho jiná část ta, která byla odkazována. Příkladem může být kliknutí na číslo strany v rejstř́iku a následné zobrazení odpovídající stránky dokumentu.

Interakce se týkají:

- aktivních čísel kapitol v obsahu;

- aktivních čísel stran v rejstř́íku;

- aktivních čísel stran, čísel kapitol a čísel obrázků ve vnitřních odkazech na strany, kapitoly, obrázky ap.; 
- aktivních názvů, čísel stran a čísel kapitol v externích referencích na jiné interaktivní dokumenty;

- aktivní menu v navigačních panelech.

Interaktivní chování do jisté míry závisí na programu, kterým dokument prohlížíme. Pokud předpokládáme, že použijeme PDFTEX pro př́mé generování PDF dokumentu nebo použijeme Acrobat Distiller pro převedení POSTSCRIPTového souboru na soubor PDF, je pak zřejmé, že pro zobrazení použijeme PDF prohlížeč, například Acrobat Reader, Acrobat Exchange nebo GHOSTVIEW.

CONTEXT je velmi mocný nástroj pro generování elektronických nebo interaktivních dokumentů PDF. V této kapitole je nicméně popsáno jenom pár standardních vlastností. Protože autoři tohoto manuálu chtějí všechny manuály věnované CONTEXTu zpřístupnit elektronicky včetně zdrojových textů, je jednou z možností, jak se důvěrně obeznámit se schopnostmi CONTEXTu, zpětné inženýrství. $^{10}$

\subsection{Interaktivní mód}

Interaktivní mód se aktivuje pomocí:

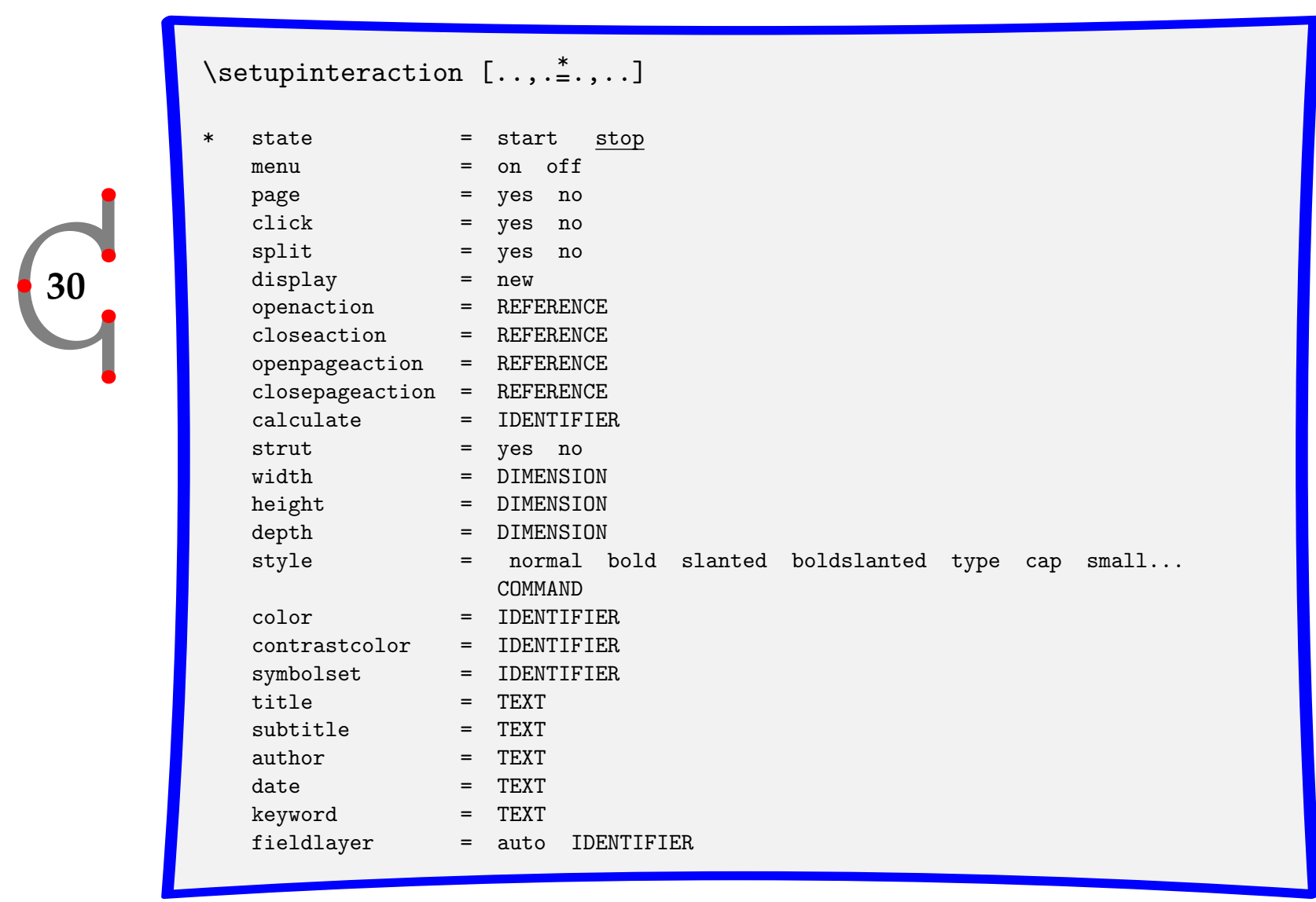

Např́klad:

10 Pozn. překl.: Interaktivitě je věnován manuál http:/ / www.pragma-ade.com/general/manuals/mwidget.pdf, viz př́lohu A. 


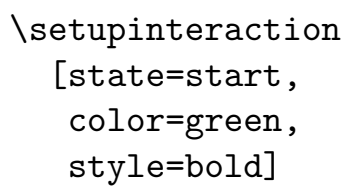

způsobí, že se začnou automaticky generovat hyperlinky a aktivní slova se zobrazí zeleně.

Interaktivní dokumenty jsou podstatně větší (v MB) než jejich papíroví bratranci, protože hyperlinky zabírají nějaké místo. Také si všimněme, že zpracování dokumentu probíhá pomaleji. Proto je výhodné interaktivní mód během př́ípravných fází tvorby dokumentu deaktivovat.

\subsection{Interaktivita $v$ rámci jednoho dokumentu}

Již dříve jsme viděli, jak vytvořit odkaz pomocí \in a \at. Možná jste se divili, proč píšeme \in\{kapitola\} [chap: uvod]. Zaprvé se tak zamezí, aby slovo kapitola a korespondujíć ćíslo bylo rozděleno řádkovým zlomem. A zadruhé bude jak slovo kapitola, tak i její číslo sázeno v interaktivním módu aktivně. Díky tomu získá čtenář větší klikatelnou oblast.

V interaktivním módu máme $\mathrm{k}$ dispozici jeden př́kaz, který v papírové variantě dokumentu nemá př́liš význam. Je jím

Igoto $\{.1 .\}.\{.2\}.[\ldots, \ldots]$

$1 \quad$ TEXT

2 TEXT

3 REFERENCE

Složené závorky obsahují uvozující nebo ukončující text reference, hranaté odkaz (referenční jméno nebo pokyn).

V \goto\{Hasseltu\}[fig:cityplan] jsou všechny ulice vybudovány do kruhu.

V interaktivním dokumentu bude slovo Hasseltu zelené a aktivní. Skočíte jím na obrázek s mapkou Hasseltu.

\subsection{Interaktivita mezi dokumenty}

Je možné odkazovat z jednoho dokumentu na jiný. Nejdříve musíme registrovat vnější dokument. Dělá se to pomocí

Juseexternaldocument [....] [..2.] [..3.]

1 IDENTIFIER

2 file

3 TEXT 
Interaktivní mód v elektronických dokumentech

První hranaté závorky musí obsahovat logické jméno dokumentu, druhý pár závorek obsahuje jméno souboru a poslední závorky obklopují pojmenování vnějšího dokumentu.

Pro odkazování takto registrovaného dokumentu použijeme

$\backslash$ from $[. * .$.

* REFERENCE

Závorky obsahují logické jméno dokumentu.

Podívejme se na následující př́ílad:

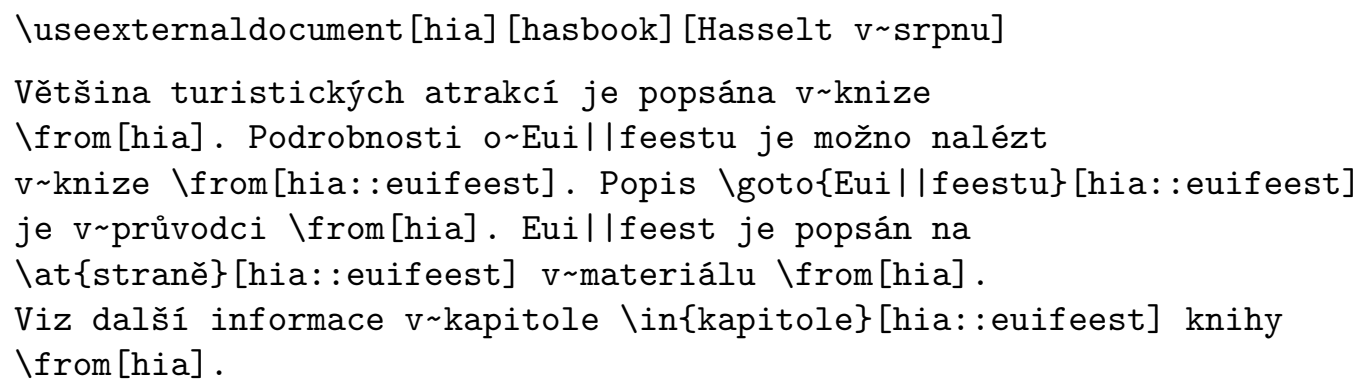

Př́kaz \useexternaldocument bývá použit v úvodní oblasti vstupního souboru.

Po zpracování našeho vstupního souboru (přinejmenším dvakrát, aby byly odkazy v pořádku) a souboru hasbook. tex, budeme mít dva PDF dokumenty. Výše uvedené odkazy mají následující význam:

- \from[hia] vyrobí aktivní titulek, který jsme uvedli v třetím páru hranatých závorek příkazu \useexternaldocument a svázán bude s první stranou hasbook.pdf.

- \from [hia: : euifeest] vyrobí aktivní titulek a sváže jej se stranou, kde začíná kapitola Euifeest.

- Igoto\{Eui||feest\}[hia: : euifeest] vyrobí aktivní slovo Eui-feest a sváže jej se stranou, kde začíná kapitola Eui-feest.

- lat\{strana\}[hia: : euifeest] vyrobí aktivní slovo strana, připojí číslo strany a sváže je s touto stranou.

- \in\{kapitola\} [hia: : euifeest] vyrobí aktivní slovo kapitola, připojí číslo kapitoly a sváže je s př́slušnou kapitolou.

Jak jsme mohli vidět, : : odděluje (logické) jméno souboru a referenční jméno doskoku v tomto dokumentu.

\subsection{Menu}

Definovat můžeme také navigační panel pomocí 


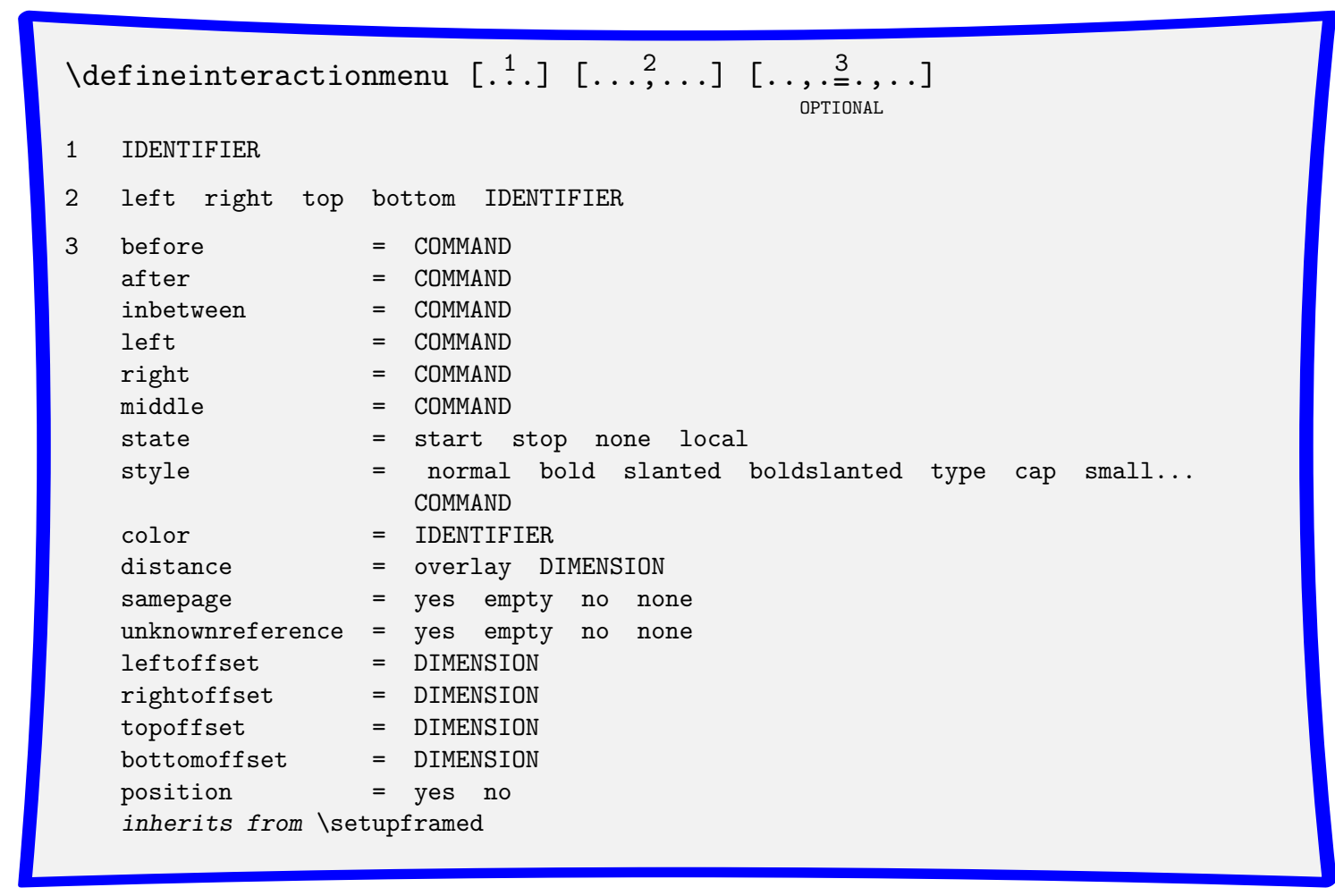

První pár závorek definuje referenční jméno, které může později být použito pro vyvolání menu. Druhé závorky určují polohu na obrazovce. Třetí nastavují menu.

Typická definice menu vypadá takto:

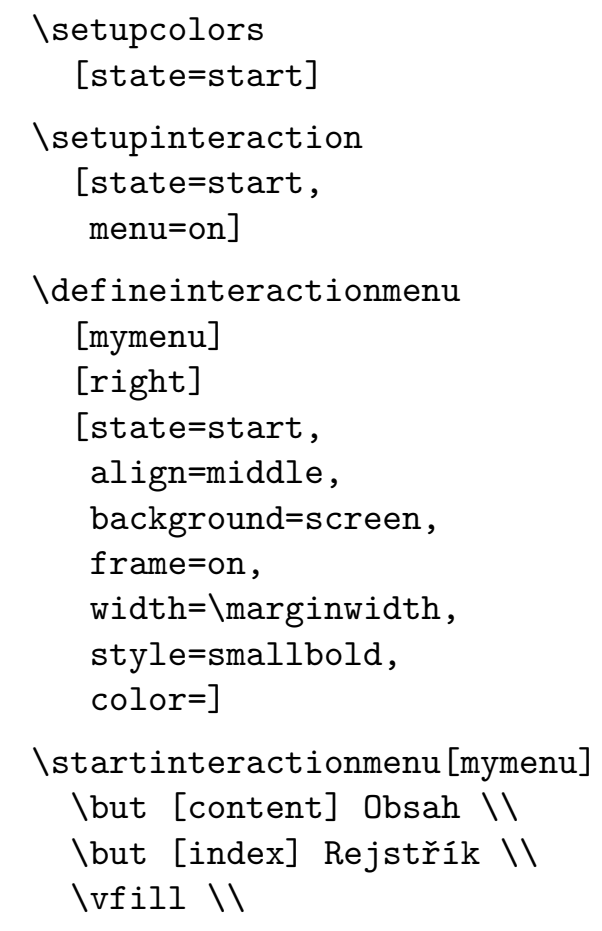




\author{
\but [ExitViewer] Konec $\backslash \backslash$ \\ \stopinteractionmenu \\ \setupheadertexts [\{\interactionmenu [mymenu] $\}]$
}

Tato definice vytvoří na pravé straně každé strany menu. Tlačítka menu budou obsahovat texty Obsah, Rejstř́ík a Konec s odpovídajícími funkcemi, po řadě: skok na obsah, skok na rejstř́í a ukončení prohlížeče. Návěští na obvyklé doskoky, jakými jsou např. content a index, jsou předdefinovány, pokud obsah a rejstř́k vložíme pomocí \completecontent a \completeindex. Jiné předdefinované funkce jsou FirstPage (první strana), LastPage (poslední strana), NextPage (další strana) a PreviousPage (předchozí strana). O vložení menu se stará \interactionmenu.

Akce typu ExitViewer (ukonči prohlížeč) je nezbytná, aby náš elektronický dokument byl samoobsažný. Jiné předdefinované akce, které můžeme použít jsou PrintDocument (tiskni), SearchDocument (prohledej dokument) a PreviousJump (skok na předchozí zobrazení).

Menu jsou nastavována pomocí:

\startinteractionmenu [.*.] ... \stopinteractionmenu

* IDENTIFIER

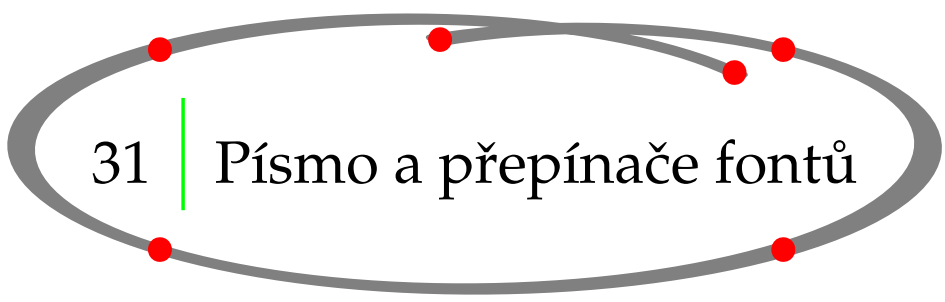

\title{
31.1 Úvod
}

Implicitní font v CONTEXTu je Computer Modern Roman $(\mathrm{cmr})$. Můžete také použít font Lucida Bright (l br) a symboly American Mathematical Society (ams). Dostupné jsou PostScriptové fonty (pos) a mnohé další.

\section{2 Řezy písma a jejich velikost}

Rodinu, řez a velikost fontu pro celý dokument vybereme pomocí:

\setupbodyf ont $[\ldots * \ldots]$

* identifier serif regular roman sans support sansserif mono type teletype handwritten calligraphic $5 \mathrm{pt} \ldots \mathrm{1}^{\mathrm{p} t}$ 
Písmo a přepínače fontů

Pokud použijeme \setupbodyf ont [ $\mathrm{cmr}$, sansserif, 9pt]

v úvodní deklarační oblasti vstupního souboru, text by měl vypadat asi takto.

Pro změnu uprostřed dokumentu, nebo na úrovni sekce, bychom měli použít:

\switchtobodyfont $[\ldots * \ldots]$

* $\quad 5 p t \quad \ldots \quad 12 p t \quad$ small big global

10. $\backslash$,listopadu (jeden den před dnem svatého Martina) chodí omladina města Hasselt dưm od domu a zpívá zvláštní píseñ určenou jen pro tuto přiležitost. Svůj zpěv doprovází na nástroj \{\em foekepot\}. Neodejdou, dokud jim nedáte nějaké penize, nebo sladkosti. Píseñ zní asi takto:

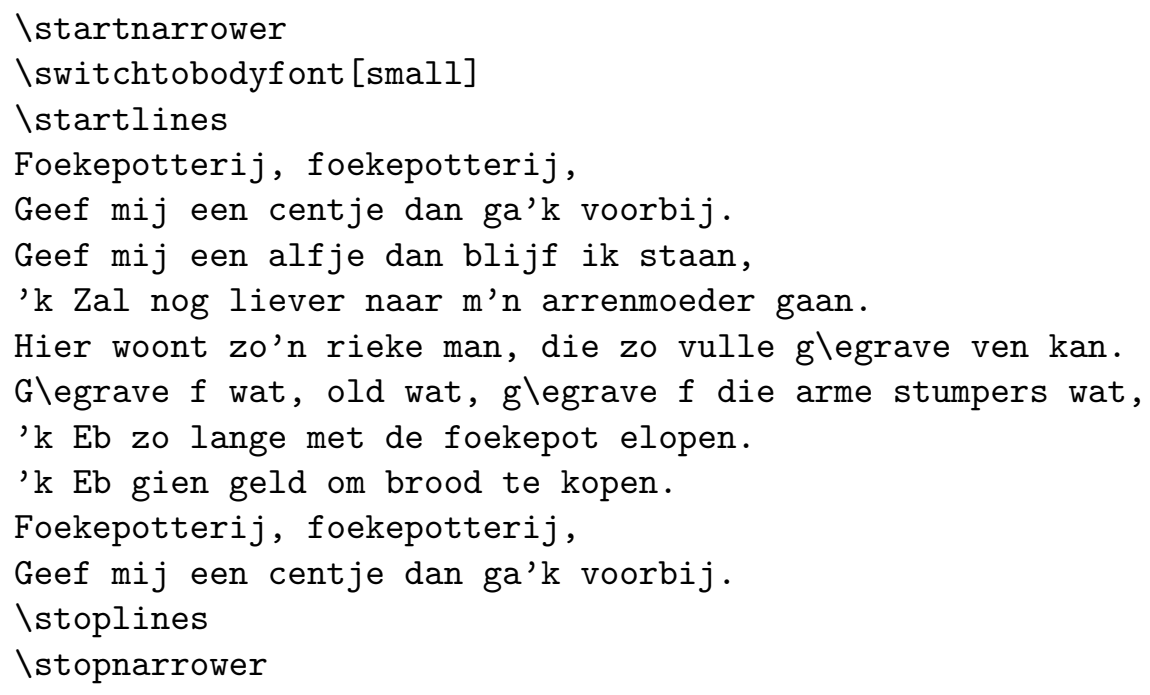

Poznamenejme ještě, že \startnarrower ... \stopnarrower se také užívá jako začátek a konec přepnutí fontu. Funkce \startlines a \stoplines v tomto př́íkladu je zřejmá.

10. listopadu (jeden den před dnem svatého Martina) chodí omladina města Hasselt dům od domu a zpívá zvláštní píseň určenou jen pro tuto příležitost. Svůj zpěv doprovází na nástroj foekepot. Neodejdou, dokud jim nedáte nějaké peníze, nebo sladkosti. Píseň zní asi takto:

Foekepotterij, foekepotterij,

Geef mij een centje dan ga'k voorbij.

Geef mij een alfje dan blijf ik staan,

' $\mathrm{k}$ Zal nog liever naar m'n arrenmoeder gaan.

Hier woont zo'n rieke man, die zo vulle gèven kan.

Gèf wat, old wat, gèf die arme stumpers wat,

' $\mathrm{k}$ Eb zo lange met de foekepot elopen.

' $\mathrm{k}$ Eb gien geld om brood te kopen.

Foekepotterij, foekepotterij,

Geef mij een centje dan ga'k voorbij.

Pokud chceme získat přehled dostupných druhů fontu zvolené rodiny, zkusme vysázet:

\showbodyf ont [cmr] 


\begin{tabular}{|c|c|c|c|c|c|c|c|c|c|c|c|c|c|}
\hline \multicolumn{12}{|c|}{$[$ modern $][\mathrm{cmr}]$} & \multicolumn{2}{|c|}{$\backslash \mathrm{mr}: \mathrm{Ag}$} \\
\hline & $\backslash \mathrm{tf}$ & $I_{s c}$ & $\backslash \mathrm{s} l$ & lit & $\backslash \mathrm{bf}$ & $\backslash \mathrm{bs}$ & $\backslash \mathrm{bi}$ & $\backslash$ tfx & $\backslash t f x x$ & $\backslash$ tfa & $\backslash t f b$ & $\backslash t f c$ & $\backslash t f d$ \\
\hline$\backslash \mathrm{rm}$ & $\mathrm{Ag}$ & $\mathrm{AG}$ & $A g$ & $A g$ & Ag & $A g$ & $A g$ & $\mathrm{Ag}$ & $\mathrm{Ag}$ & $\mathrm{Ag}$ & $\mathrm{Ag}$ & $\mathrm{Ag}$ & $\mathrm{Ag}$ \\
\hline$\backslash$ \s & $\mathrm{Ag}$ & $\mathrm{Ag}$ & $\mathrm{Ag}$ & $A g$ & Ag & Ag & Ag & $\mathrm{Ag}$ & $\mathrm{Ag}$ & $\mathrm{Ag}$ & $\mathrm{Ag}$ & $\mathrm{Ag}$ & \\
\hline$\backslash t t$ & $\mathrm{Ag}$ & $\mathrm{AG}$ & $A g$ & $A g$ & $\mathrm{Ag}$ & $\mathrm{Ag}$ & $\mathrm{Ag}$ & $\mathrm{Ag}$ & $\mathrm{Ag}$ & $\mathrm{Ag}$ & $\mathrm{Ag}$ & $\mathrm{Ag}$ & Ag \\
\hline
\end{tabular}

\subsection{Přepínače řezu a velikosti v parametrech př́íkazů}

V mnoha př́kazech jeden z parametrů indikuje požadovaný styl sazby. Například:

\setuphead [chapter] [style $=\backslash \mathrm{tfd}]$

$\mathrm{V}$ tomto př́padě je velikost písma nadpisu kapitol nastavena na $\backslash t f d$. Místo takovéhoto příkazu bychom ale měli používat předdefinované volby, které se vztahují $\mathrm{k}$ aktuálnímu druhu fontu:

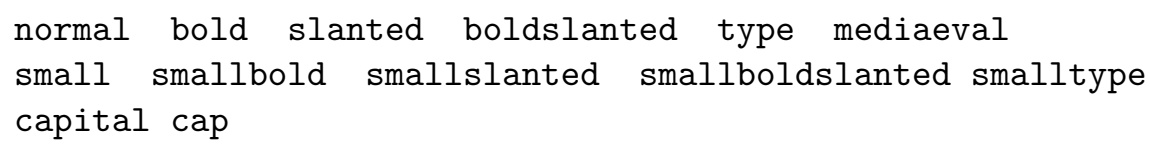

\subsection{Lokální řez písma a jeho velikost}

V běžném textu můžeme měnit styl písma na roman, bezpatkové a neproporcionální (strojopisné) pomocí př́kazů \rm, \ss a \tt.

Řez písma, jako kurzíva, skloněné nebo tučné, můžeme měnit pomocí \it, \sl a \bf.

Velikost písma lze měnit $\mathrm{v}$ rozmezí od 4 pt do 12pt a nastavuje se pomocí \switchtobodyfont.

Aktuální styl je $\mathrm{v}$ př́íkazu přednastaven pomocí \tf. Pokud chceme zvětšit velikost písma, pou-

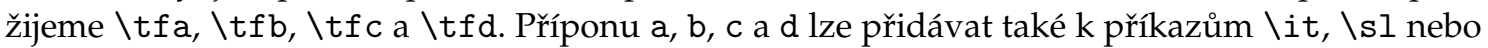
$\backslash \mathrm{bf}$.

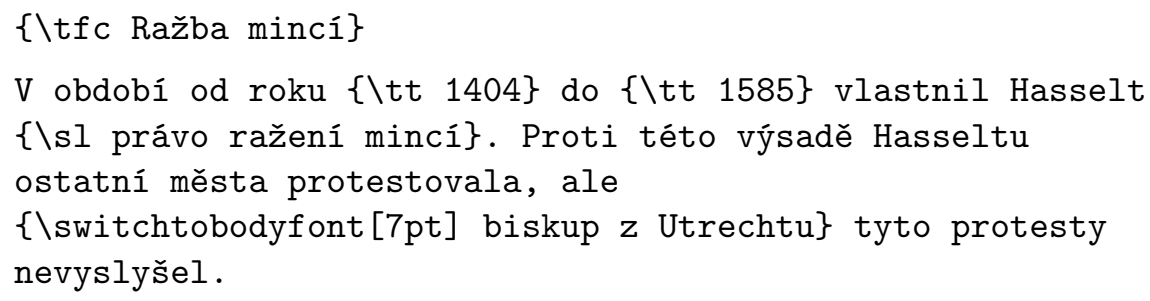

Složená závorka indikuje začátek a konec oblasti, která je ovlivněna přepínačem stylu nebo velikosti.

\section{Ražba mincí}

V období od roku 1404 do 1585 vlastnil Hasselt právo ražení mincí. Proti této výsadě Hasseltu ostatní města protestovala, ale biskup z Utrechtu tyto protesty nevyslyšel.

\subsection{Předefinování velikosti fontu}

Ve zvláštních případech můžeme definovat svou vlastní velikost fontu. 
\definebodyfont $[\ldots, \ldots][.2].[\ldots, . \stackrel{3}{=} ., \ldots]$

$1 \quad 5 p t \quad \ldots \quad 12 p t$ default

2 rm $\mathrm{ss}$ tt $\mathrm{mm}$ hw $\mathrm{cg}$

3 tf $=$ FILE

$\mathrm{bf}=$ FILE

sl = FILE

it $=$ FILE

$\mathrm{bs}=$ FILE

$\mathrm{bi}=\mathrm{FILE}$

$\mathrm{SC}=\mathrm{FILE}$

$\mathrm{ex}=\mathrm{FILE}$

$\mathrm{mi}=$ FILE

sy $=$ FILE

$\mathrm{ma}=\mathrm{FILE}$

$\mathrm{mb}=$ FILE

$\mathrm{mc}=\mathrm{FILE}$

Tato definice by měla vypadat asi takto:

Idefinebodyfont [10pt] [rm] [tfe=Regular at 36pt]

$\{\backslash$ tfe Hasselt! $\}$

Nyní př́kaz \tfe vysází velikostí 36pt nápis: TaSSelt!

\subsection{Kapitálky}

Zkratky jako PDF (Portable Document Format) jsou tištěny pomocí malých kapitálek. Malé kapitálky jsou o něco menší, než počáteční písmena vět v aktuálním fontu a mohou být vysázeny pomocí:

\cap $\{. *$.

* TEXT

Pokud porovnáme PDF, \cap $\{\mathrm{PDF}\}$ a \sc pdf

PDF, PDF a pdf

PDF, PDF a PDF (Computer Modern Roman)

můžeme vidět zřetelně rozdíl. Př́ḱkaz \sc vytváří skutečné kapitálky (musí existovat jako samostatný font), zatímco pseudokapitálky \cap jsou vytvořeny geometrickou deformací verzálek.

\subsection{Zvýraznění}

Pro jednotné zvýraznění slov v dokumentu používáme příkaz:

$\backslash$ em 
Zvýrazněná slova se implicitně vysází skloněným stylem.

Při procházce Hasseltem bychom měli $\{\backslash b f$ \em dávat pozor $\}$

na $\{\backslash$ em Amsterodamy\}. Slovem $\{\backslash$ em Amsterodamy\} $\{\backslash \mathrm{bf} \backslash \mathrm{em}$ nejsou\}

míněni obyvatelé Amsterodamu, ale malé kamenné pilíře, oddělující chodník od silnice. Jsou zamýšleny jako ochrana chodců před projíždějícími auty, ale ve skutečnosti se lidé častěji

zraní, když o ně zakopnou.

Při procházce Hasseltem bychom měli dávat pozor na Amsterodamy. Slovem Amsterodamy nejsou míněni obyvatelé Amsterodamu, ale malé kamenné pilíře, oddělující chodník od silnice. Jsou zamýšleny jako ochrana chodců před projíždějícími auty, ale ve skutečnosti se lidé častěji zraní, když o ně zakopnou.

Pokud něco dvakrát zdůrazníme, vysází se to opět nezdůrazněně.

\subsection{Strojopis alias režim verbatim}

Pokud si přejeme zobrazit text přesně tak, jak jsme ho uvedli do vstupního souboru, s ukončením řádek přsesně tam, kde jste použili ENTER, použijeme:

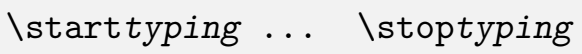

V textu můžeme použít:

\type $\{\ldots *\}$

Složené závorky ohraničují strojopisný text. Sestavujme jej opatrně, protože v něm již nefunguje běžný mechanismus zalamování řádků.

Nastavení režimu verbatim můžeme provádět pomocí: 


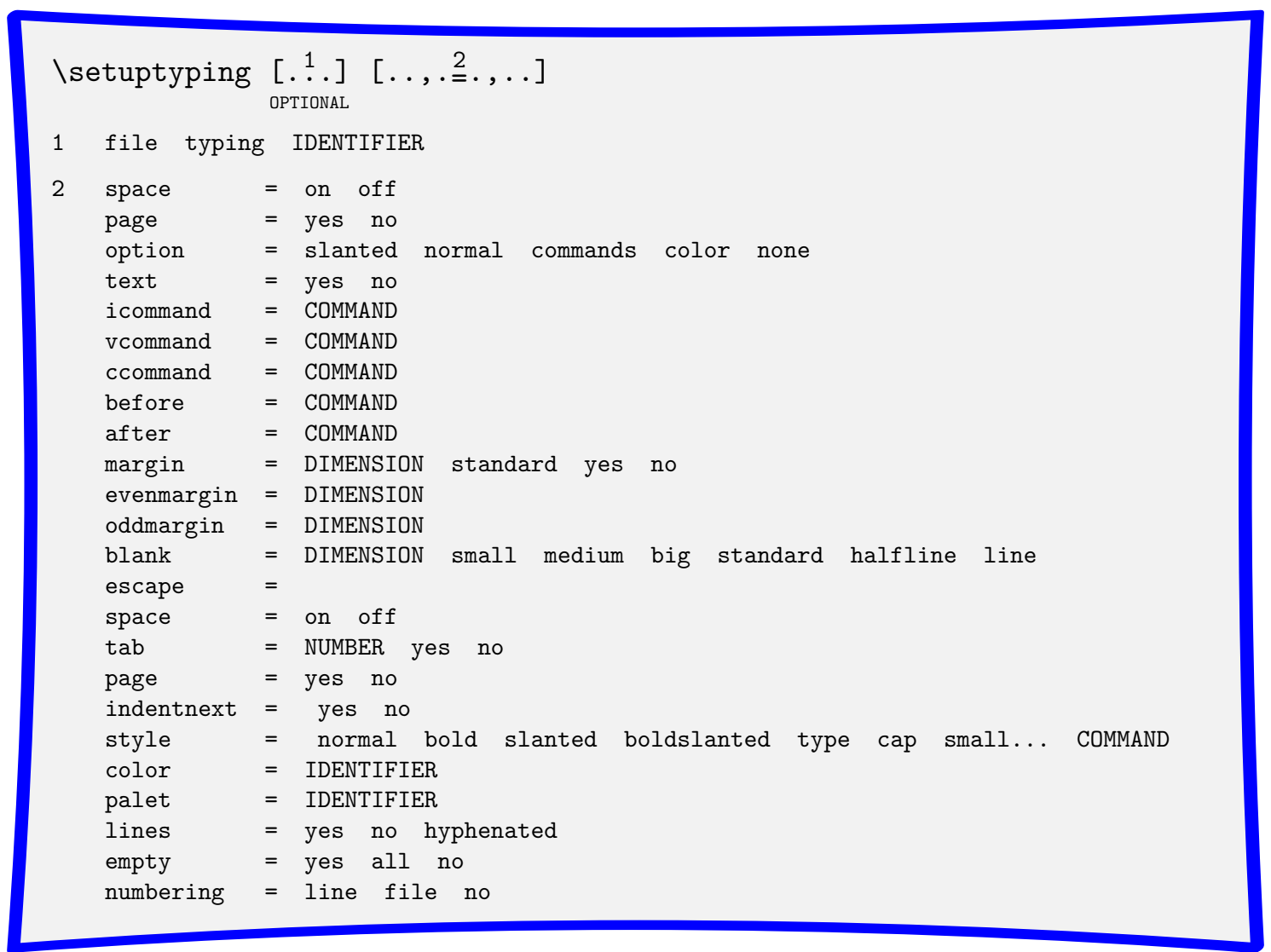

\setuptype $[\ldots, . * *, \ldots]$

* space $=$ on off

option $=$ slanted normal none

style $=$ normal bold slanted boldslanted type cap small... COMMAND

color $=$ IDENTIFIER

\subsection{Kódování znaků}

Každý font je připraven v jednom nebo více kódováních. Při zavedení fontu pomocí fontových definičních tabulek, tzv. typescriptů, je nutné toto kódování specifikovat. Pro kódování ec, používané v Evropě nejčastěji, vypadá načtení písma Computer Modern takto:

lusetypescript [modern] [ec]

\setupbodyfont [modern, 10pt,rm]

Typ kódování fontu volíme podle toho, v jakém kódování máme vzory dělení slov v použitém jazyce. Toto kódování se dovíme zapsáním \showpatterns, viz tabulka 31.1. 


\begin{tabular}{cccccc}
\hline language & encoding & mapping & number & left $_{\text {min }}$ & right $_{\text {min }}$ \\
\hline en & ec & ec & 1 & 2 & 3 \\
uk & ec & ec & 2 & 3 & 3 \\
de & texnansi & texnansi & 3 & 2 & 2 \\
de & ec & ec & 4 & 2 & 2 \\
fr & texnansi & texnansi & 5 & 2 & 2 \\
fr & ec & ec & 6 & 2 & 2 \\
es & ec & ec & 7 & 2 & 2 \\
pt & texnansi & texnansi & 8 & 2 & 2 \\
pt & ec & ec & 9 & 2 & 2 \\
it & texnansi & texnansi & 10 & 2 & 2 \\
it & ec & ec & 11 & 2 & 2 \\
nl & texnansi & texnansi & 12 & 2 & 2 \\
nl & ec & ec & 13 & 2 & 2 \\
cz & il2 & il2 & 14 & 2 & 2 \\
cz & ec & ec & 15 & 2 & 2 \\
sk & il2 & il2 & 16 & 2 & 2 \\
sk & ec & ec & 17 & 2 & 2 \\
pl & pl0 & pl0 & 18 & 2 & 2 \\
pl & ec & ec & 19 & 2 & 2 \\
pl & qx & qx & 20 & 2 & 2 \\
\hline
\end{tabular}

Tabulka 31.1 Výpis př́kazu \showpatterns.

Př́pravu fontu se správným kódováním i s předgenerováním typescriptů lze svěřit prográmku texfont.

Pokud náš editor pracuje v jiném kódování, než je kód fontu, pak je nutné text překódovat. O to se postará CONTEXT, pokud vstupní kódování našeho dokumentu uvedeme v hranaté závorce př́kazu:

\enableregime $[. *$..]

* Latin1 Latin2 Latin7 Latin15 iso-8859-1 iso-8859-2 iso-8859-7 iso-8859-15 cp1250 cp1251 cp1252 cp1253 cp1254 cp1257 viscii cyr grk mac utf8 unicode

\section{Složené znaky}




\section{1 Úvod}

V kapitole 3 jste již viděli, že pro vysázení speciálních znaků jako \# \$ \% \& _ \{ a \} musíme napsat více než jeden symbol. Akcentovaná písmena nebo cizokrajné symboly musí být složeny z více znaků, aby byl vytvořen správně vysázený znak.

Nad rámec této příručky vychází problematika akcentovaných písmen v matematickém režimu. Informace o této problematice najdete $\mathrm{v} \mathrm{T}_{\mathrm{E}} \mathrm{XBooku}$ Donalda E. Knutha.

\subsection{Akcenty}

Kromě přímého vstupu znaků s diakritikou pomocí vhodného kódování (viz kapitolu 31.9), můžeme v CONTEXTu akcentovaná písmena složit z jednoduchých znaků a diakritických znamének. Tabulka 32.1 ukazuje, jak kompozit vytvoříme. Písmeno $u$ je uvedeno jenom jako příklad.

\begin{tabular}{cc|cc}
\hline Napíšeme & Dostaneme & Napíšeme & Dostaneme \\
\hline$\backslash \backslash\{\mathrm{u}\}$ & $\grave{u}$ & $\backslash \mathrm{u}\{\mathrm{u}\}$ & $\breve{\mathrm{u}}$ \\
$\backslash \backslash\{\mathrm{u}\}$ & $\mathfrak{u}$ & $\backslash \mathrm{v}\{\mathrm{u}\}$ & $\check{\mathrm{u}}$ \\
$\backslash \backslash\{\mathrm{u}\}$ & $\hat{\mathrm{u}}$ & $\backslash \mathrm{H}\{\mathrm{u}\}$ & ú \\
$\backslash "\{\mathrm{u}\}$ & $\ddot{u}$ & $\backslash \mathrm{b}\{\mathrm{u}\}$ & $\underline{\mathrm{u}}$ \\
$\backslash \sim\{\mathrm{u}\}$ & $\tilde{\mathrm{u}}$ & $\backslash \mathrm{d}\{\mathrm{u}\}$ & $\underline{u}$ \\
$\backslash=\{\mathrm{u}\}$ & $\overline{\mathrm{u}}$ & $\backslash \mathrm{c}\{\mathrm{u}\}$ & $\mathrm{u}$ \\
$\backslash .\{\mathrm{u}\}$ & $\dot{\mathrm{u}}$ & $\backslash \mathrm{k}\{\mathrm{u}\}$ & $\mathrm{u}$ \\
$\backslash \mathrm{r}\{\mathrm{u}\}$ & $\stackrel{\mathrm{u}}{ }$ & & \\
\hline
\end{tabular}

Tabulka 32.1 Akcenty

Asi nechceme psát písmena ì nebo j (s tečkami). Z písmen $i$ a $j$ vytvoříme složené znaky následujícím způsobem:

$\backslash "\{\backslash i\} \quad \ddot{i}$

$\backslash-\{\backslash j\} \quad \hat{\jmath} \quad(j$ bez tečky nemusí být ve všech písmech $\mathrm{k}$ dispozici)

\subsection{Cizokrajné symboly}

Jak se sestavují písmena a znaky, které se vyskytují v cizích jazycích, uvádí tabulka 32.2.

\begin{tabular}{|c|c|c|c|}
\hline Napíšeme & Dostaneme & Napíšeme & Dostaneme \\
\hline loe & $œ$ & $\backslash 0$ & $\varnothing$ \\
\hline$\backslash O E$ & $\Subset$ & $\backslash 1$ & 1 \\
\hline$\backslash \mathrm{ae}$ & $æ$ & $\backslash \mathrm{L}$ & $€$ \\
\hline$\backslash A E$ & $\nexists$ & $\backslash \mathrm{SS}$ & $B$ \\
\hline$\backslash a a$ & å & $?^{c}$ & $i$ \\
\hline$\backslash \mathrm{AA}$ & $\AA$ & $!^{\prime}$ & $\mathrm{i}$ \\
\hline 10 & $\varnothing$ & \texteuro & $€$ \\
\hline
\end{tabular}

Tabulka 32.2 Cizokrajná písmena a znaky 


\section{Formátování stránky}

Mnoho dalších symbolů je definováno v externích množinách. Zavádějí se př́kazem

\usesymbols $[. *$...

* IDENTIFIER

V hranatých závorkách je trojpísmenný název množiny, např. eur, nav, mvs, jmn, uni. Seznam znaků dané množiny se zobrazí př́ikazem

\showsymbolset $[. *$. $]$

* IDENTIFIER

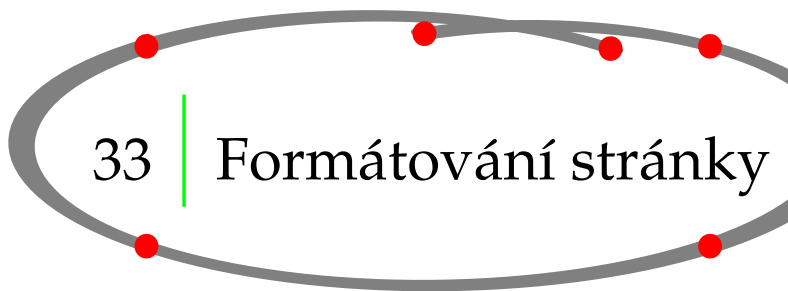

Formát stránky je definován př́kazem: 
Formátování stránky

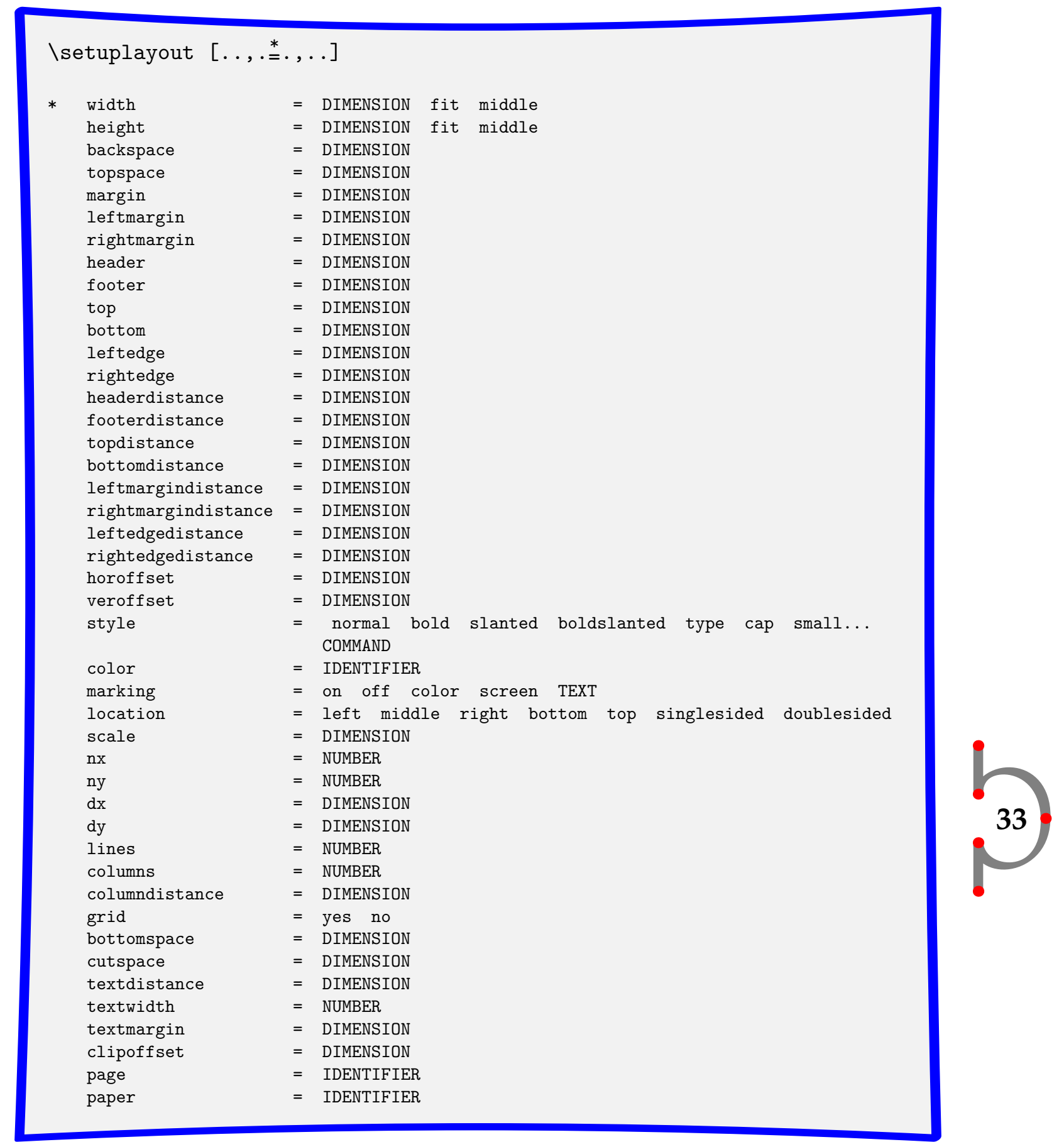

Tento povel se píše do deklarační oblasti vstupního souboru.

Měli bychom se obeznámit s parametry, které popisují formát stránek (stránkové zrcadlo). Stránka je rozdělena na několik oblastí jako například text, záhlaví, úpatí atd. Velikosti těchto částí se dají nastavit př́kazem \setuplayout.

Různé oblasti ve formátu stránky jsou popsány na obrázku 33.1. Okraj je také nazýván marginálií. 


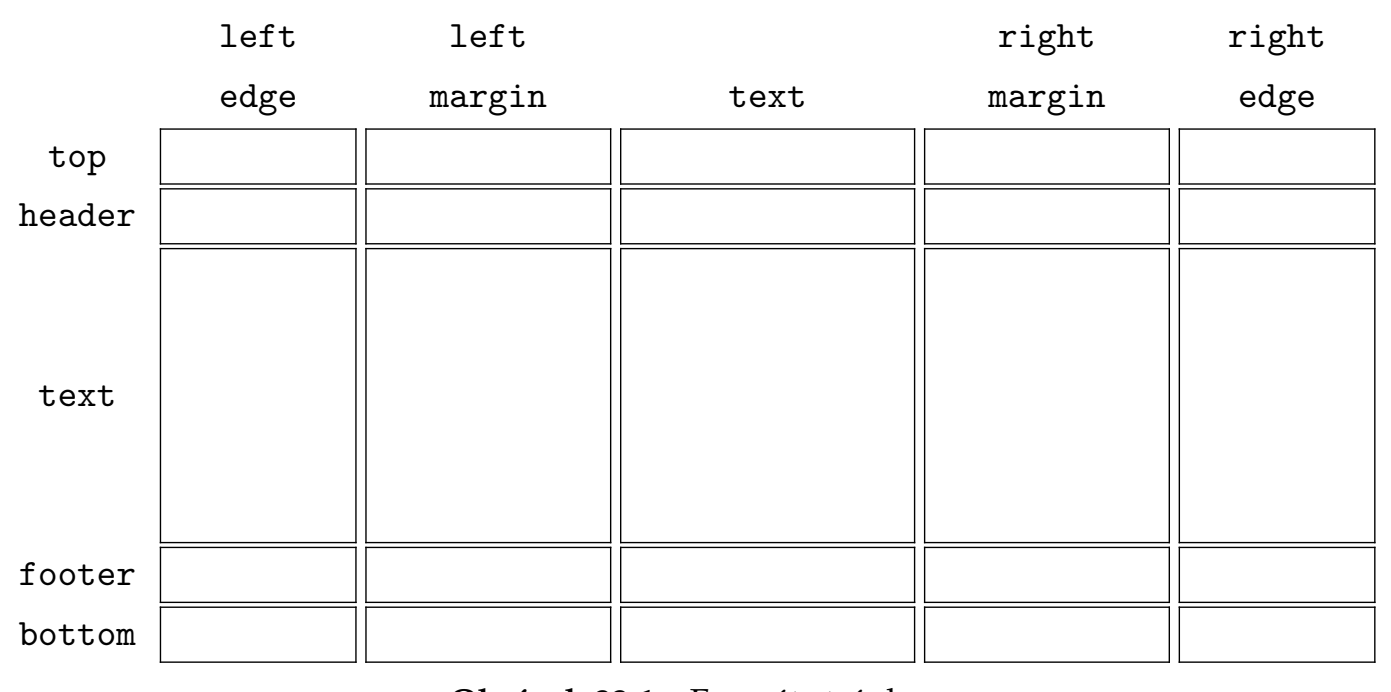

Obrázek 33.1 Formát stránky.

Pokud chceme vidět formát stránkového zrcadla, můžeme napsat př́íkaz \showframe a zpracovat jednu stranu nebo celý soubor. Oblasti jsou pak na stránce vyznačeny několika barevnými rámečky.

Př́kaz \showsetups ukáže hodnoty parametrů. Kombinací obou příkazů je povel \showlayout.

Hodnoty formátovacích parametrů jsou dostupné jako př́íkazy (viz tabulku 33.2). To nám umožňuje přesněji definovat rozměry sloupců, obrázků a tabulek. Některé z těchto parametrů jsou vysvětleny $\mathrm{v}$ tabulce 33.1 .

\begin{tabular}{ll}
\hline Př́kazy & Význam \\
\hline$\backslash$ makeupwidth & šířka zrcadla sazby \\
$\backslash$ makeupheight & výška zrcadla sazby \\
\textwidth & šířka textové oblasti \\
\textheight & výška textové oblasti \\
\hline
\end{tabular}

Tabulka 33.1 Několik

parametrů ve formě př́ikazů.

Jestliže chceme definovat šířku sloupce nebo výšku obrázku, můžeme to udělat relativně k hodnotám \makeupwidth nebo \makeupheight. Změny nastavení šîrky nebo výšky stránky pak proporcionálně změní rozměry sloupce nebo obrázku.

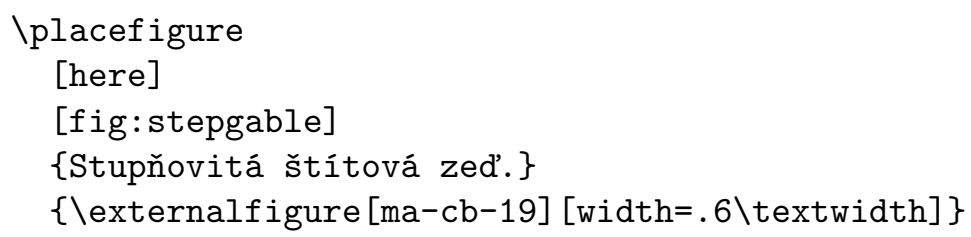

Po zpracování dostaneme: 


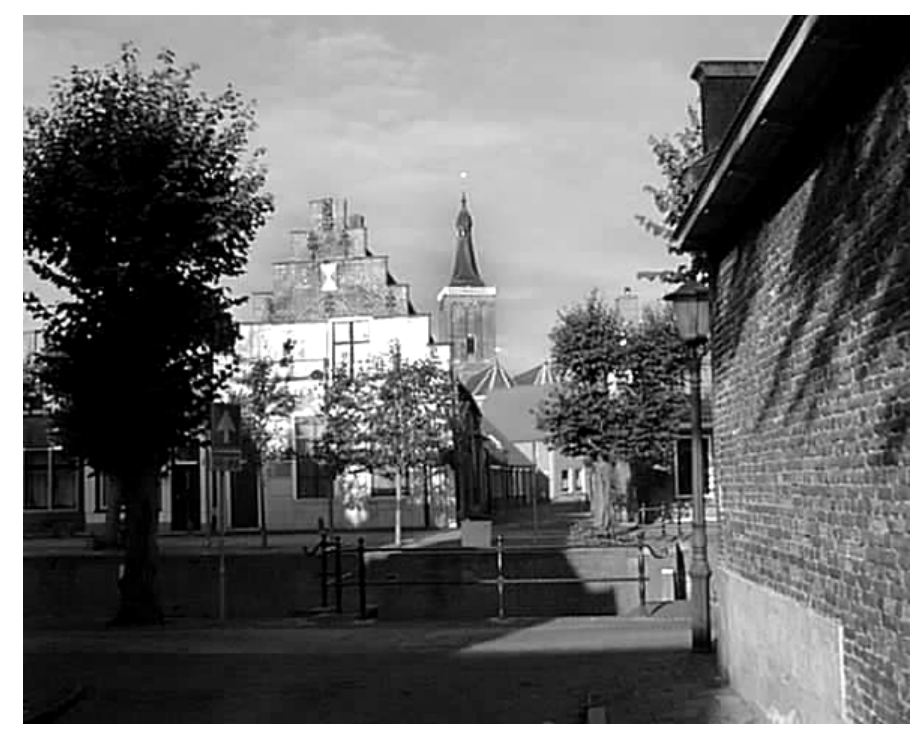

Obrázek 33.2 Stupňovitá štítová zed'.

Ostatní vzdálenosti a rozměry jsou uvedeny v tabulce 33.2.

Př́kaz \setuplayout je definován v deklarační oblasti vstupního souboru, před povelem Istarttext. To znamená, že hodnoty parametrů jsou globální a platné pro celý dokument. Nicméně pokud pro některé stránky chceme vykonat drobné změny rozvržení stránky, použijeme

\adaptlayout $[21,38]$ [height $=+.5 \mathrm{~cm}]$

V tomto případě budou mít strany 21 a 38 výšku rovnou $0,5 \mathrm{~cm}$ + výška stránky.

Na lokální změny formátu stránky můžete použít příkaz:

\startlocal ... \stoplocal

Např́klad:

\start

\startlocal

$\backslash$ setuplayout [height $=+.5 \mathrm{~cm}$ ]

\stoplocal

Hasselt má úplně jiné uspořádání než většina měst kvůli svým opevněním a hradním příkopům.

$\backslash$ stop

Neradíme používat tyto lokální změny př́liš často. Vždycky je lepší pozměnit text nežli měnit formát stránky.

\begin{tabular}{ll}
\hline Parametr & Příkaz \\
\hline vzdálenost vršku & \topdistance
\end{tabular}

Tabulka 33.2.a Parametry pro úpravu stránky. 


\section{Odsazení odstavců}

\begin{tabular}{|c|c|}
\hline výška vršku & \topheight \\
\hline vzdálenost záhlaví & \headerdistance \\
\hline výška záhlaví & \headerheight \\
\hline horní mezera & \topspace \\
\hline úroveň hlavičky & \headlevel \\
\hline vnitřní okraj & \backspace \\
\hline vzdálenost marginálií & \margindistance \\
\hline šířka každé z marginálií & $\backslash$ marginwidth \\
\hline šířka levé marginálie & $\backslash$ leftmarginwidth \\
\hline šířka pravé marginálie & \rightmarginwidth \\
\hline vzdálenost hran & ledgedistance \\
\hline šíŕka každé z hran & ledgewidth \\
\hline šířka levé hrany & $\backslash$ leftedgewidth \\
\hline šířka pravé hrany & \rightedgewidth \\
\hline výška papíru & \paperheight \\
\hline šířka papíru & $\backslash$ paperwidth \\
\hline výška zrcadla & \makeupheight \\
\hline šířka zrcadla & \makeupwidth \\
\hline výška textu & Itextheight \\
\hline šíŕka textu & \textwidth \\
\hline vzdálenost úpatí & $\backslash$ footerdistance \\
\hline výška úpatí & Ifooterheight \\
\hline vzdálenost spodku & Ibottomdistance \\
\hline výška spodku & lbottomheight \\
\hline
\end{tabular}

Tabulka 33.2.b Parametry pro úpravu stránky.

\section{Odsazení odstavců}

\section{1 Úvod}

$\mathrm{V} \mathrm{TE}_{\mathrm{E}} \mathrm{Xu}$ a CONTEXTu je nejdůležitějš́ jednotkou textu odstavec. Nový odstavec můžeme začít

- prázdným řádkem,

- př́íkazem \par. 


\section{Odsazení odstavců}

Ve vstupním ASCII souboru je vhodné jako oddělovače odstavců využívat prázdné rádky. Dostaneme tak přehlednější a lépe strukturovaný text, ve kterém se snadněji odhalují případné chyby.

Pokud si přejeme ukončit odstavec výslovně př́kazem, použijeme \par.

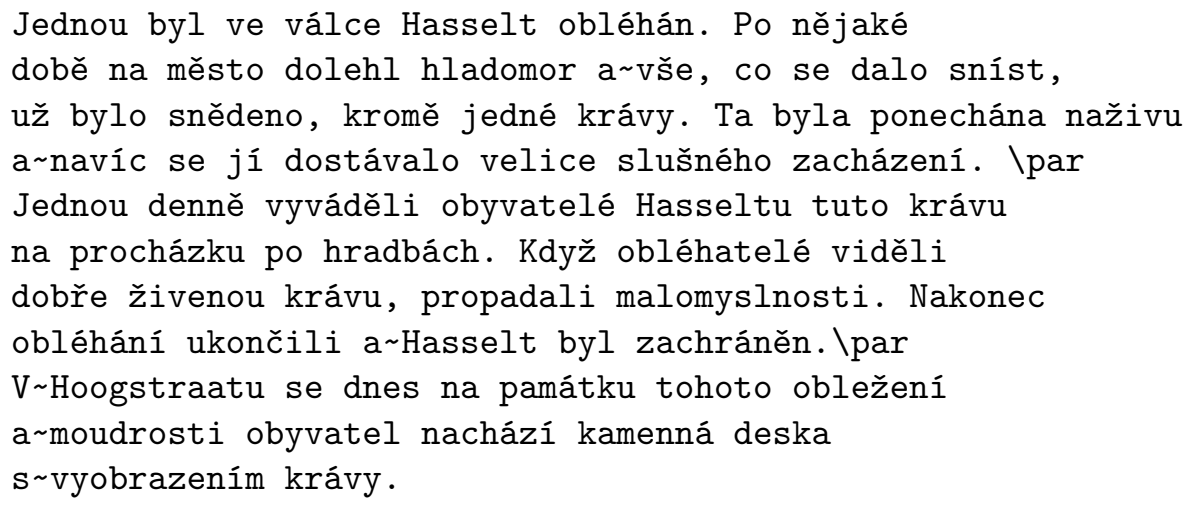

Místo příkazů \par bychom mohli také použít několik prázdných řádků:

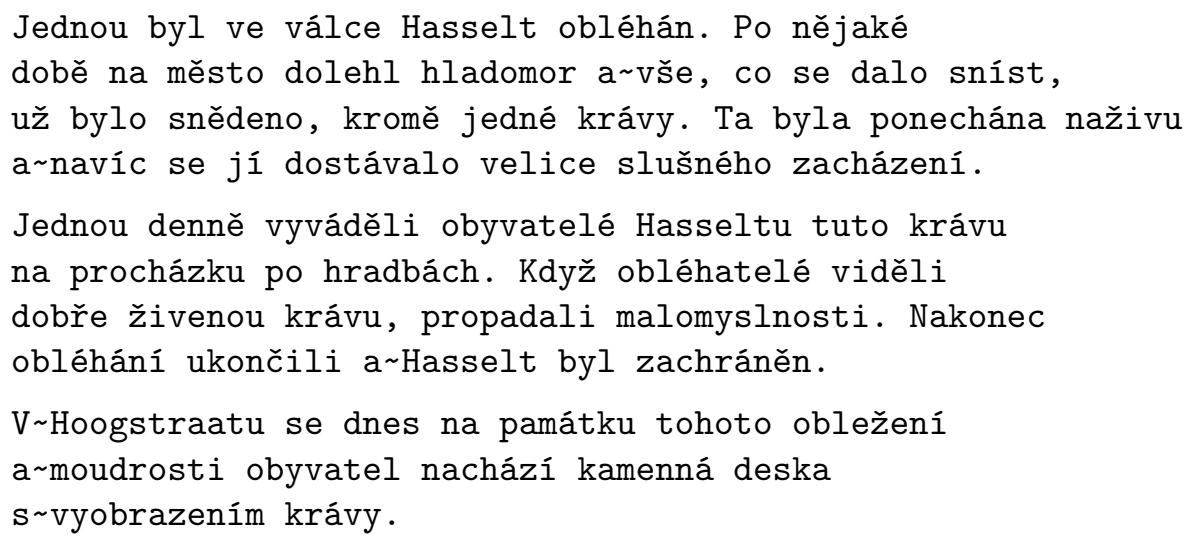

\subsection{Mezera mezi odstavci}

Velikost mezery mezi odstavci lze nastavit pomocí:

Tento dokument je vysázen s nastavením \setupwhitespace [medium] .

Když je velikost meziodstavcové mezery nastavena, máme k dispozici dva př́kazy, které jsou nicméně potřeba jen zř́ídka:

$\backslash$ nowhitespace

$\backslash$ whitespace

Pokud odstavec obsahuje vodorovné linky, nebo orámovaný text, jako například Ridderstraat 27, 8061GH Hasselt 


\section{Odsazení odstavců}

pak se stává, že rozestup není optimální. V takovém případě lze provést korekci pomocí:

\section{\startlinecorrection ... \stoplinecorrection}

Pokud tedy napíšeme:

Istartlinecorrection

$\backslash$ framed\{Ridderstraat 27, 8061GH Hasselt\}

Istoplinecorrection

dostaneme lepší výstup. Tyto př́ikazy ale používejme, jen pokud je to opravdu nezbytné!

Ridderstraat 27, 8061GH Hasselt

Další př́íkaz pro ovládání mezery mezi odstavci je:

$\backslash$ blank $[\ldots, \ldots]$

OPTIONAL

* small medium big nowhite back white disable force reset line halfline FORMULA fixed flexible none

Hranaté závorky za př́kazem jsou nepovinné a umožňují nastavit velikost mezery mezi odstavci. Klíčová slova jako small, medium a big nastavují mezeru relativně vzhledem k velikosti daného fontu.

Oficiální název Hasselt má vždy příponu Ov, což je zkratka provincie $\{\backslash$ em Overijssel\}.

$\backslash$ blank [2*big]

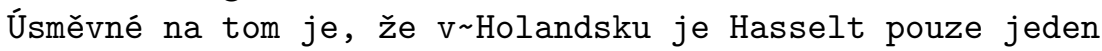
a tato přípona je tedy nadbytečná.

$\backslash$ blank

Tato přípona je pozůstatkem z dob, kdy Holandsko a Belgie

byly jednou zemí pod vládou španělského krále Filipa II.

$\backslash$ blank [2*big]

Hasselt v Belgii leží v provincii Limburg, ale Belgičané

na své dopisy Hasselt (Li) zřejmě nepíší.

Př́kaz \blank bez hranatých závorek představuje obvyklou mezeru.

Náš př́ílad by vypadal:

Oficiální název Hasselt má vždy příponu Ov, což je zkratka provincie Overijssel.

Úsměvné na tom je, že v Holandsku je Hasselt pouze jeden a tato př́ípona je tedy nadbytečná.

Tato př́pona je pozůstatkem z dob, kdy Holandsko a Belgie byly jednou zemí pod vládou španělského krále Filipa II.

Hasselt v Belgii leží v provincii Limburg, ale Belgičané na své dopisy Hasselt (Li) zřejmě nepíší. 
Velikost obvyklé mezery lze ovládat pomocí:

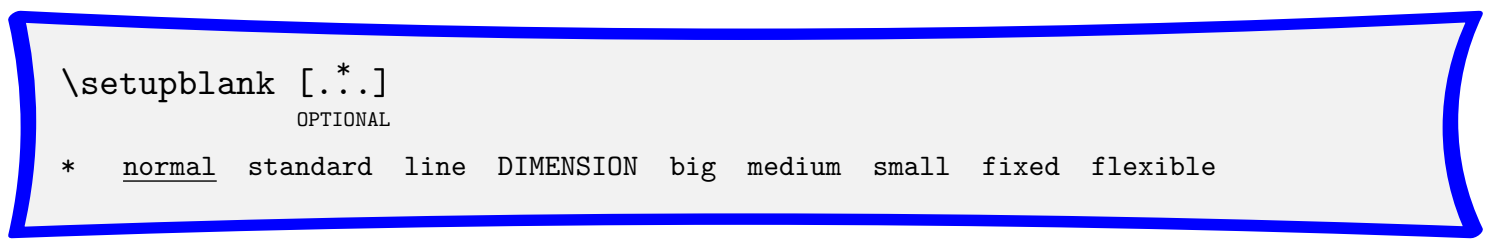

Pokud chceme potlačit tuto meziodstavcovou mezeru, můžeme použít:

\startpacked $[\ldots] \ldots$ \... \stoppacked

OPTIONAL

* blank

$\mathrm{V}$ tomto dokumentu je mezera nastavena na medium ale na následujících řádcích je tato mezera potlačena a řádky jsou tedy semknuty $\mathrm{k}$ sobě.

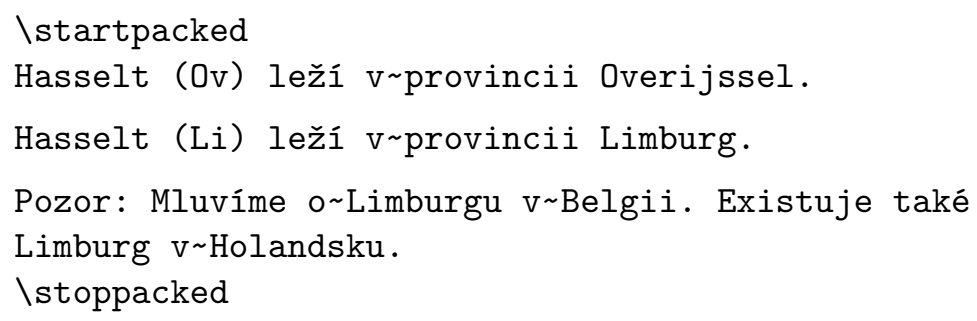

Vysázeno bude:

Hasselt (Ov) leží v provincii Overijssel.

Hasselt (Li) leží v provincii Limburg.

Pozor: Mluvíme o Limburgu v Belgii. Existuje také Limburg v Holandsku.

Není těžké si představit, k čemu slouží:

\section{\startunpacked ... \stopunpacked}

Vertikální mezeru si lze také vynutit pomocí př́kazu \godown. Její velikost je nastavena v závorkách.

\godown $[. *$ *..]

* DIMENSION

\subsection{Odsazení}

Velikost odsazení nastavíme pomocí: 
\setupindenting $[\ldots, \ldots]$

* never none not no yes always first next small medium big normal odd even DIMENSION

Rozumného odsazení se dosáhne pomocí:

\setupindenting [medium]

Tímto bude první rádka odstavce odsazená. Jen po mezeře (vysázené př́ikazem \blank) je v základním nastavení odsazení potlačeno.

Lokálně na určitém místě můžeme odsazování ovládat pomocí:

\indenting $[\ldots, \ldots]$

* never none not no yes always first next small medium big normal odd even DIMENSION

Když například použijeme never, budou od toho okamžiku všechna odsazení potlačena. Příkaz none ovlivní pouze následující odstavec.

Pokud používáme odsazování a na určitém místě si odsazení nepřejeme, můžeme také použít:

\noindenting

Globální př́íkazy se umist'ují v deklarační oblasti vstupního souboru, před povelem \starttext. $\mathrm{V}$ př́loze $\mathrm{B}$ je uveden přehled dostupných př́ikazů a jejich parametrů.

Nastavovací př́íkazy mají stejnou strukturu. Vypadají třeba takto: 
\setupparagraphs $[. \stackrel{1}{.}][.2 .].[\ldots, . \stackrel{3}{=} ., \ldots]$ OPTIONAL

1 IDENTIFIER

2 NUMBER each

3 style = normal bold slanted boldslanted type cap small... COMMAND

width $\quad=$ DIMENSION

height $\quad=$ DIMENSION

align = inner outer left right middle normal no yes

tolerance $=$ verystrict strict tolerant verytolerant stretch

distance $=$ DIMENSION

before $\quad=$ COMMAND

after $\quad=$ COMMAND

inner $\quad=$ COMMAND

command $=$ COMMAND

rule $\quad=$ on off

Deklarační povely se více nebo méně skládají z logického jména a určitého počtu dvojic hranatých závorek. Tyto můžou být nepovinné, v tom př́padě je pod nimi napsáno slovo OPTIONAL. Dvojice hranatých závorek mohou $\mathrm{v}$ definici obsahovat:

\setupacommand [.1.] [.2.] [.... .....]

Čárky ve třetí závorce naznačují, že zde může být vložen seznam parametrů, rovnítko značí, že jde o parametry typu klíč=hodnota. Čísla .1. a .2. odkazují na vysvětlivky za definicí. Ty nám říkají, jaké volby můžeme uvést v první, druhé a třetí hranaté závorce.

Implicitní volby a hodnoty parametrů jsou podtrženy. Navíc si můžeme všimnout, že některé hodnoty jsou vysázeny verzálkami: SECTION, NAME, DIMENSION, NUMBER, COMMAND, and TEXT. Toto naznačuje, že nejde o konstantní hodnoty, ale o hodnoty určitého typu:

SECTION název oddílu, např́ílad chapter, section, subsection atd.;

NAME identifikátor (logické jméno);

DIMENSION rozměr $\mathrm{v}$ jednotkách $\mathrm{cm}, \mathrm{pt}$, em, ex, sp nebo in;

NUMBER celé ćíslo;

COMMAND př́kaz s daným počtem parametrů;

TEXT text.

\section{Definování př́kazů / maker}


CONTEXT je sada maker založená na TEXu. TEX je programovací jazyk a zároveň typografický systém. To znamená, že si můžeme sami naprogramovat určité vlastnosti, pokud takovou flexibilitu potřebujeme.

Nový př́íkaz můžeme nadefinovat pomocí

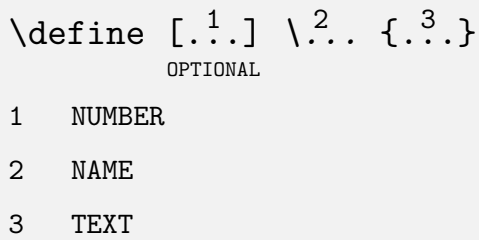

Následující př́klad objasní jeho použití.

Můžeme mít bohatě ilustrovaný dokument a pokud jsme již unavení psaním

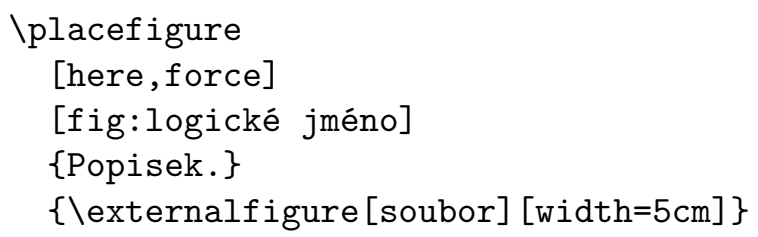

můžeme si definovat vlastní prríkaz s několika proměnnými:

- logické jméno;

- popisek;

- soubor.

Naše definice př́kazu a jeho volání může vypadat takto:

$\backslash$ define [3] \mujobrazek

$$
\{\backslash \text { placefigure }
$$

$$
\begin{aligned}
& \text { [here,force] [fig:\#1] } \\
& \{\# 2\}\{\text { lexternalfigure [\#3] [width }=5 \mathrm{~cm}]\}\}
\end{aligned}
$$

V hranatých závorkách [3] stanovujeme, že chceme tři proměnné \#1, \#2 a \#3. Při volání př́kazu \mujobrazek musíme vložit tyto tři proměnné hodnoty mezi složené závorky. Výsledkem bude: Programování sofistikovanějších příkazů je ponecháno na čtenáři.

Kromě definování př́kazů můžeme také navíc definovat dvojici \start ... \stop.

\definestartstop $[. .1].[\ldots, .2 ., \ldots]$

1 IDENTIFIER

2 before $=$ COMMAND

after $\quad=$ COMMAND

style $=$ normal bold slanted boldslanted type cap small... COMMAND

commands $=$ COMMAND 


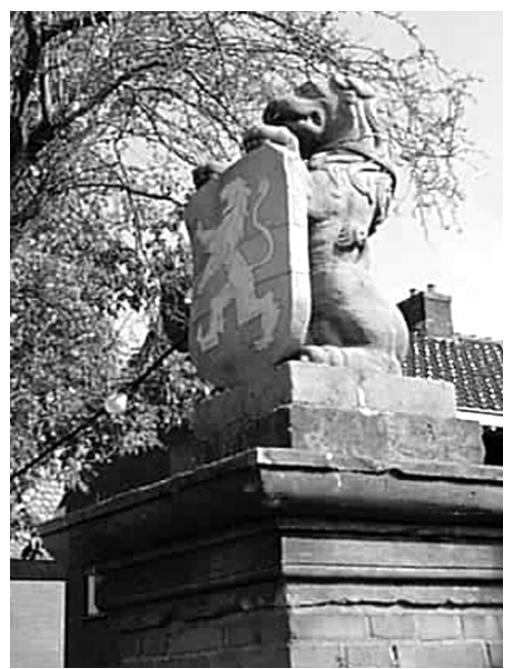

Obrázek 36.1

Holandský lev na stráži.

Např́klad:

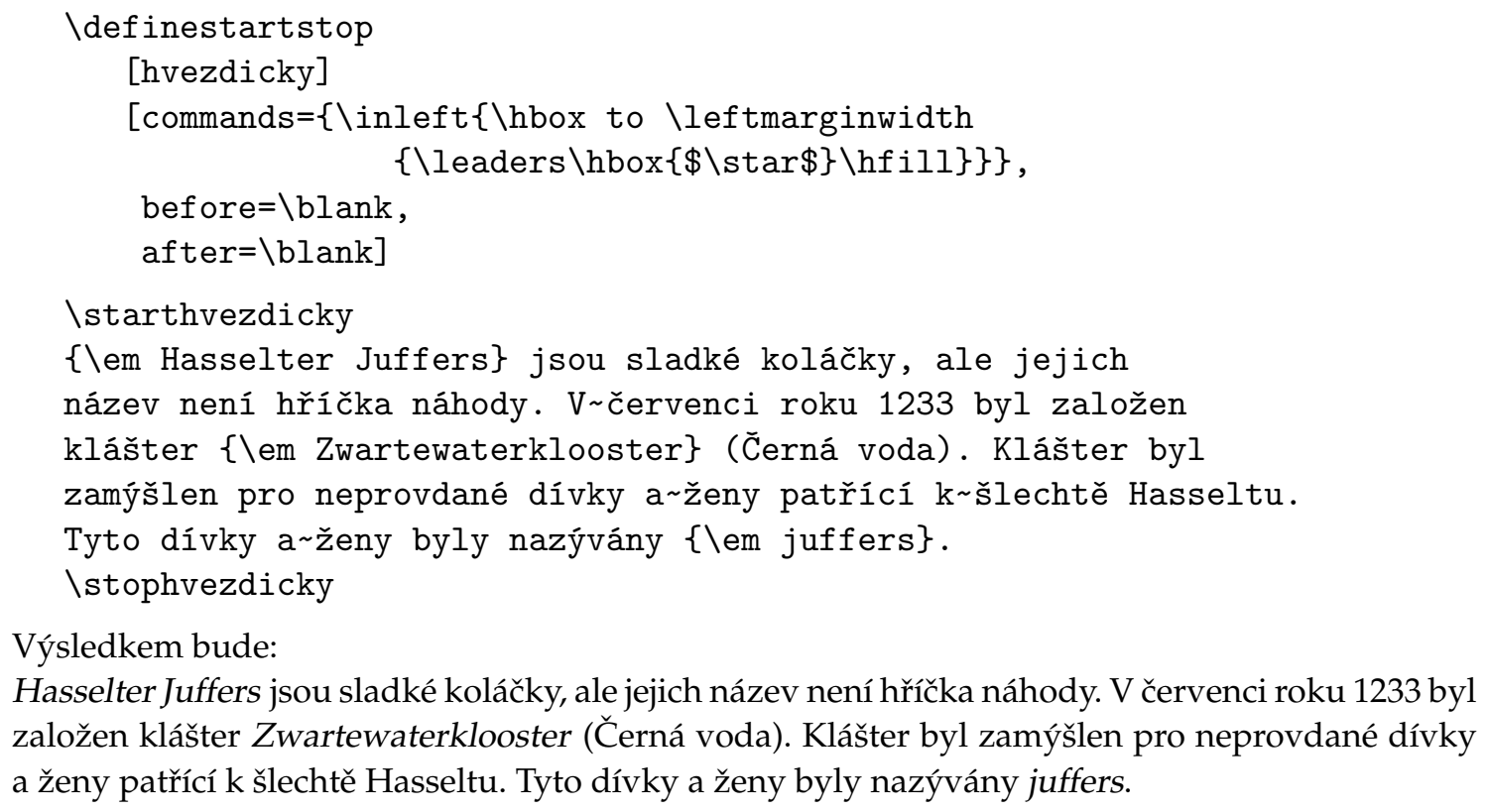

Výsledkem bude:

Hasselter Juffers jsou sladké koláčky, ale jejich název není hříčka náhody. V červenci roku 1233 byl založen klášter Zwartewaterklooster (Černá voda). Klášter byl zamýšlen pro neprovdané dívky a ženy patřící k šlechtě Hasseltu. Tyto dívky a ženy byly nazývány juffers. 


\section{Nezařazené}

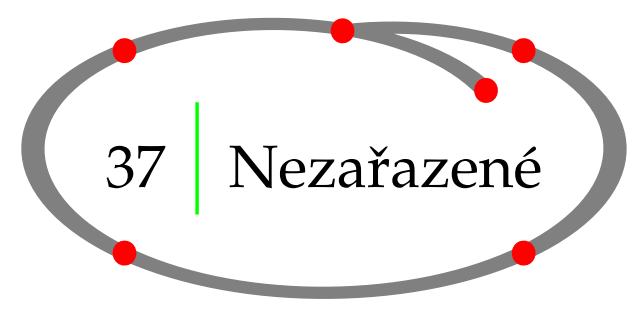

\subsection{Titulní strana}

V prvním př́íkladu tohoto manuálu na straně 5 jsme použili př́kaz

\startnamemakeup $[\ldots, . * *, \ldots] \quad \ldots \quad \backslash$ stopnamemakeup

$$
\text { OPTIONAL }
$$

* inherits from \startmakeup

Tento př́kaz může být použit k definování titulních stran, protože mívají jinak velká stránková zrcadla než hlavní textová část dokumentu. Často $\mathrm{k}$ návrhu vzhledu takové výjimečné strany využíváme předdefinované dvojice \start ... \stopstandardmakeup.

Jednoduchá titulní strana může vypadat takto:

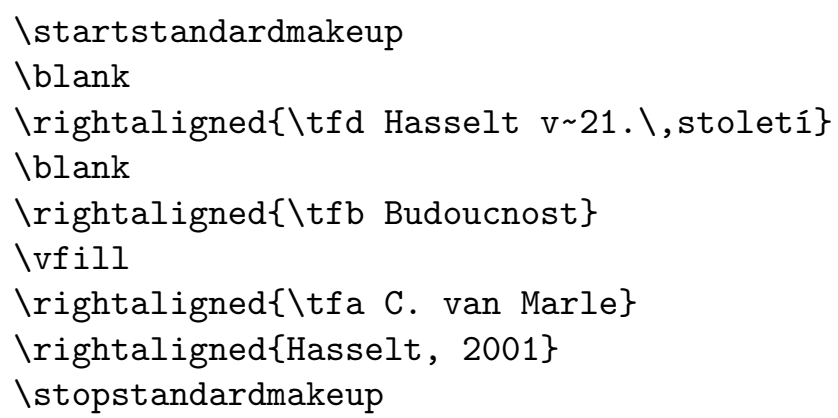

V oboustranném dokumentu musíme vykonat některé další akce, abychom vysázeli zadní stranu titulního listu. Předešlý př́klad v takovém případě změníme na:

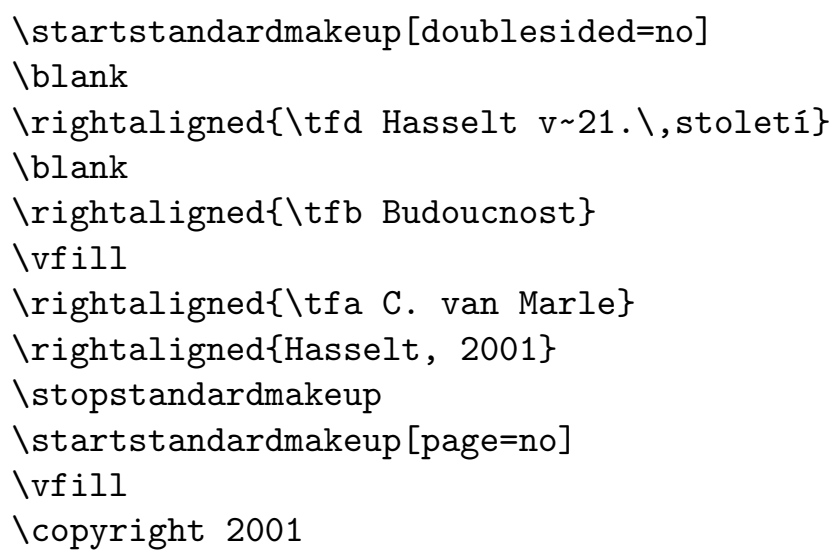




\section{Nezařazené}

Tato kniha je věnována lidem žijícím v Hasseltu. Chceme poděkovat fotografovi J. Jonkerovi za zfalšováni fotografii do této knihy tak, že čtenář získá jasnou představu o budoucí podobě Hasseltu. \stopstandardmakeup

Naše vlastní titulní strana může být navržena pomocí př́ikazů

\definemakeup $[. \stackrel{1}{.}][\ldots, . \stackrel{2}{=} .,$.

1 IDENTIFIER

2 inherits from \setupmakeup

a

$\backslash$ setupmakeup $[. \stackrel{1}{.}][\ldots, .2 ., \ldots]$

1 IDENTIFIER

2 width $=$ DIMENSION

height $\quad=$ DIMENSION

voffset $\quad=$ DIMENSION

hoffset $\quad=$ DIMENSION

page $\quad=$ left yes right

commands $=$ COMMAND

doublesided $=$ yes no empty

headerstate $=$ normal stop start empty none nomarking

footerstate $=$ normal stop start empty none nomarking

textstate = normal stop start empty none nomarking

topstate $=$ stop start

bottomstate $=$ stop start

pagestate $=$ stop start

color $=$ IDENTIFIER

\subsection{Plovoucí objekty}

Plovoucím objektem (floating block) se v CONTEXTu nazývá textový element, např. tabulka či obrázek, který je zpracován speciálním způsobem. Již jsme viděli použití \placefigure a \placetable. Oba jsou prŕíkladem plovoucích objektů popsaných v kapitolách 10 a 11.

Svůj vlastní plovoucí objekt si můžeme definovat pomocí

\definefloat [....] [..2.]

1 SINGULAR NAME

2 PLURAL NAME

Složené závorky se používají pro jméno objektu v jednotném a množném čísle. Například: 


\section{Nezařazené}

\definefloat [vsuvka] [vsuvky]

Nyní jsou k dispozici následující př́kazy:

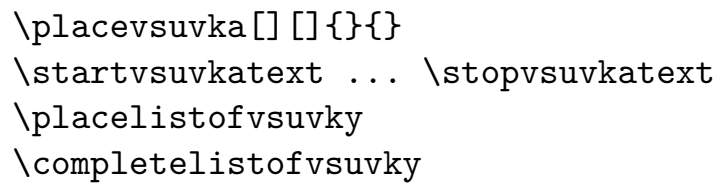

Nově definovaný plovoucí objekt může být nastaven pomocí

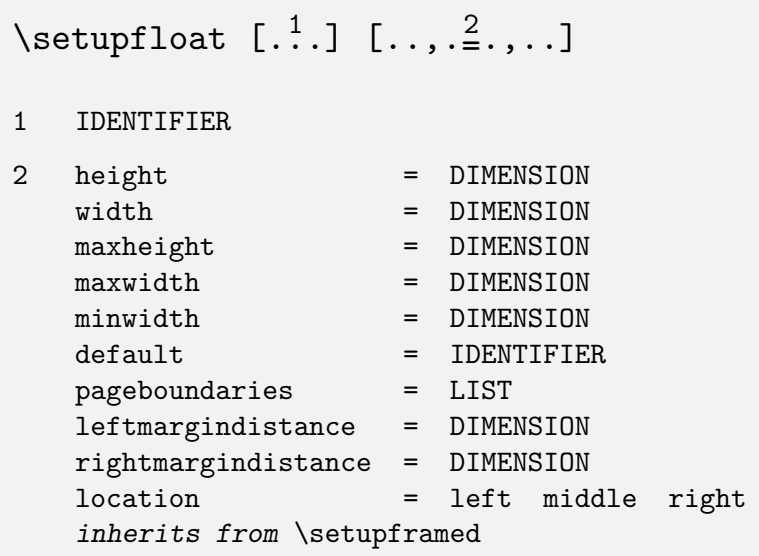

Dále můžeme nastavit formátování všech plovoucích objektů pomocí příkazu

$\backslash$ setupfloats $[\ldots, . * ., \ldots]$

* location width

before

after

margin

spacebefore

spaceafter

sidespacebefore

sidespaceafter

indentnext

ntop

nbottom

nlines

default

tolerance

leftmargindistance

rightmargindistance

sidealign

numbering

inherits from \setupframed
$=$ left right middle

= fit DIMENSION

= COMMAND

= COMMAND

= DIMENSION

= small medium big none

= small medium big none

$=$ small medium big none

$=$ small medium big none

$=$ yes no

$=$ NUMBER

$=$ NUMBER

$=$ NUMBER

$=$ IDENTIFIER

$=012$

$=$ DIMENSION

$=$ DIMENSION

$=$ normal line

$=$ yes nocheck

Č́́slování a popisek objektu lze nastavit pomocí 


\section{Nezařazené}

\setupcaption $[. \stackrel{1}{.}][\ldots, . \stackrel{2}{=}, \ldots]$

1 IDENTIFIER

2 inherits from \setupcaptions

a

\setupcaptions $[\ldots, \stackrel{*}{=}, \ldots]$

* location = top bottom none high low middle

width $=$ fit broad max DIMENSION

minwidth $=$ fit DIMENSION

headstyle $=$ normal bold slanted boldslanted type cap small... COMMAND

style $=$ normal bold slanted boldslanted type cap small... COMmAND

number $\quad=$ yes no

inbetween $=$ COMMAND

align = inner outer left right middle normal no yes

conversion $=$ numbers characters Characters romannumerals Romannumerals

way $=$ bytext bycd:section

separator $=$ TEXT

stopper $\quad=$ TEXT

command $\quad=$ COMMAND

distance $=$ DIMENSION

Tyto příkazy používáme v úvodní části vstupního souboru. \setupfloats a \setupcaptions mají globální vliv na všechny plovoucí objekty. Následuje kompletní ukázka nového plovoucího objektu.

\setupfloats [location=middle]

Isetupcaption [location=bottom, headstyle=boldslanted]

\definefloat [vsuvka] [vsuvky]

$\backslash$ placevsuvka\{Ukázka vsuvky.\}

\startframedtext

$\mathrm{Na}$ začátku tohoto století existovala tramvajová linka z Zwolle do Blokzijl přes Hasselt. Později nabývaly na významu jiné dopravní prostředky a tramvajová trat byla před druhou světovou válkou zrušena. Nyní by taková tramvajová linka možná byla zase zisková. \stopframedtext

Na začátku tohoto století existovala tramvajová linka z Zwolle do Blokzijl přes Hasselt. Později nabývaly na významu jiné dopravní prostředky a tramvajová trat' byla před druhou světovou válkou zrušena. Nyní by taková tramvajová linka možná byla zase zisková.

Vsuvka 37.1 Ukázka vsuvky. 


\section{Nezařazené}

\subsection{Blok textu}

Jiným stavebním kamenem dokumentu je blok textu. Př́íkladem bloku textu je jeden nebo více odstavců, které chceme použít několikrát.

Blok textu musíme definovat pomocí

\defineblock $[. *$. $]$

* IDENTIFIER

Mezi hranaté závorky vložíme jeho referenční jméno.

\defineblock [holandstina]

Také můžeme najednou definovat několik bloků textu, pokud mezi jednotlivá jména napíšeme čárku.

Po zadefinování máme $\mathrm{k}$ dispozici následující dvojici:

\beginholandstina ... \endholandstina

$\mathrm{S}$ blokem můžeme pracovat pomocí př́ikazů

$\backslash$ hideblocks $[\ldots, \ldots][\ldots, \ldots]$

OPTIONAL

1 IDENTIFIER

2 IDENTIFIER

Iuseblocks $[\ldots, \ldots][\ldots, \ldots]$

OPTIONAL

1 IDENTIFIER

2 IDENTIFIER

$\backslash$ keepblocks $[\ldots, \ldots][\ldots, \ldots]$

OPTIONAL

1 IDENTIFIER

2 all IDENTIFIER 


\section{Nezařazené}

\selectblocks $[\ldots, \ldots][\ldots, \ldots][. \stackrel{3}{=}$.

OPTIONAL OPTIONAL

1 IDENTIFIER

2 IDENTIFIER

3 criterium $=$ all SECTION

Zde je př́íklad jejich použití:

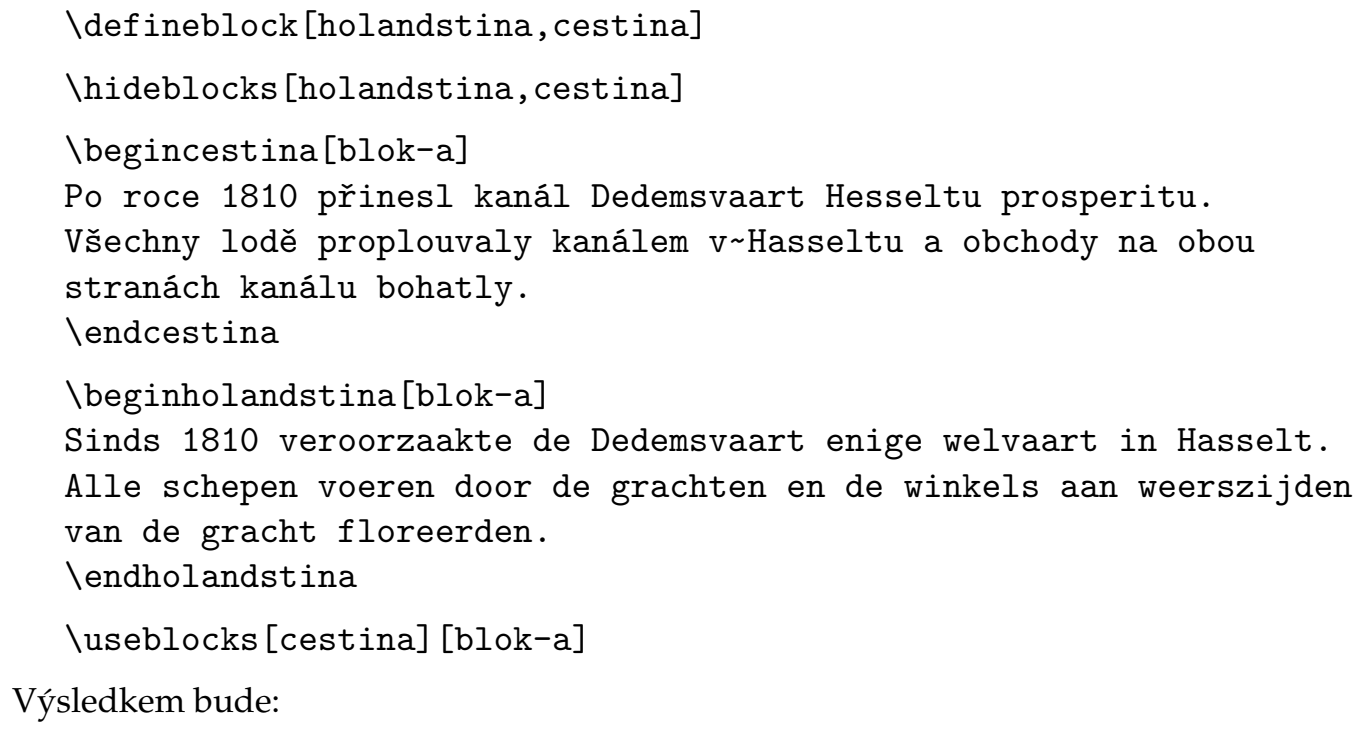

Výsledkem bude:

Po roce 1810 přinesl kanál Dedemsvaart Hesseltu prosperitu. Všechny lodě proplouvaly kanálem v Hasseltu a obchody na obou stranách kanálu bohatly.

Jestliže budeme pokračovat $\mathrm{v}$ takovémto používání bloku textu, můžeme vytvořit dvojjazyčný manuál. Pro tyto účely je také možno uložit bloky textu do externích souborů:

Isetupblock[holandstina] [file=store-h]

Holandský blok textu je uložen do souboru store-h . tex a fragmenty textu mohou být vyvolány jejich referenčními jmény.

\subsection{Uložení textu pro pozdější použití}

Dočasně můžeme uložit informace pro budoucí použití v dokumentu pomocí \startbuffer $\underset{\text { OPTIONAL }}{[. * .]} \ldots \quad$ \stopbuffer

* IDENTIFIER

Například: 


\section{Nezařazené}

Istartbuffer [navsteva]

Chcete-li vidět, co vám Hasselt může nabídnout, měli byste jej

někdy navštívit. Jestliže si s sebou vezmete tento manuál,

některá místa poznáte.

Istopbuffer

Igetbuffer [navsteva]

Příkazem \getbuffer[navsteva] se vyvolá uložený text. Referenční jméno můžeme vynechat, CONTEXT pak pracuje $s$ interním jménem. Přetisk uložené informace získáme pomocí \typebuffer [navsteva].

Nastavení se provádí př́kazem

\setupbuffer $[.1].[\ldots, . \stackrel{2}{=}, \ldots]$

OPTIONAL

1 IDENTIFIER

2 paragraph $=$ NUMBER

before $=$ COMMAND

after $=$ COMMAND

\subsection{Skrytý text}

Text může být skryt pomocí

\starthiding ... \stophiding

Vložený text nebude zpracováván.

\subsection{Linky}

37 Máme k dispozici mnoho příkazů na kreslení linek. Jednu linku vysázíme pomocí

\hairline

nebo

$\backslash$ thinrule

Více linek najednou nakreslíme pomocí 


\section{Nezařazené}

\thinrules $[. \stackrel{*}{=}$.

OPTIONAL

* inherits from \setupthinrules

Možná je také kombinace textu a linek:

Hasselt - Amsterdam

Kdybychom nakreslili spojnici Hasseltu s Amsterdamem, prošli bychom vzdálenost téměr̆ $145 \mathrm{~km}$.

Kdybychom nakreslili dvě spojnice Hasseltu s Amsterdamem, prošli bychom vzdálenost téměř $290 \mathrm{~km}$.

Amsterdam

Hasselt

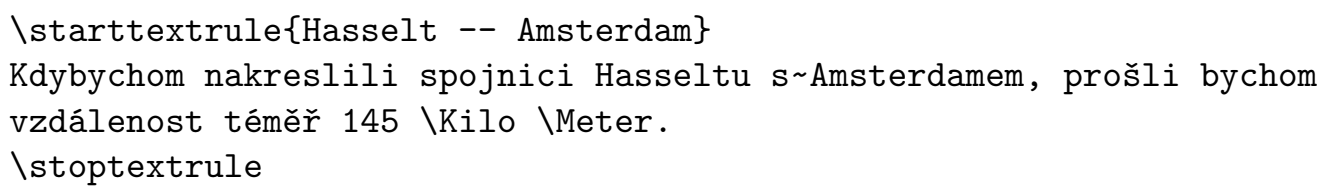

Amsterdam \thinrules[n=3] Hasselt

Při kreslení linek musíme být vždy opatrní. Prázdné řádky okolo \thinrules nesmí být opomenuty a výsledné vertikální odsazení by mělo být vždy předmětem naší pozornosti.

Vertikální odsazení můžeme nastavit pomocí

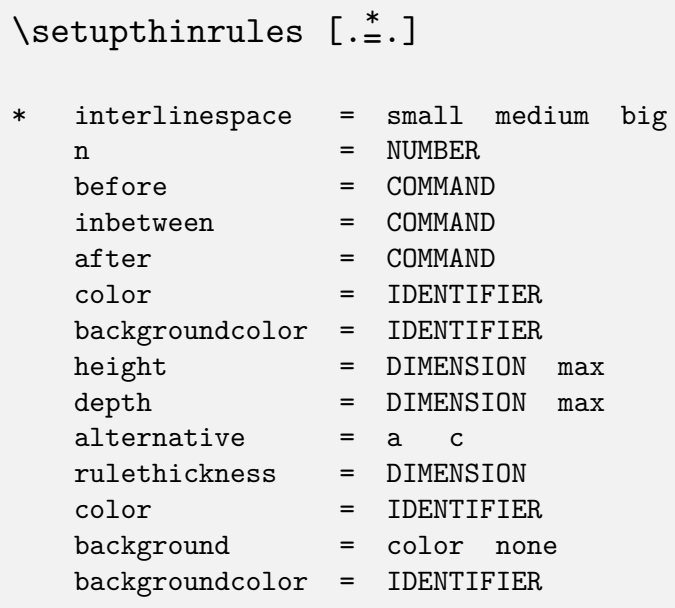

Dále máme k dispozici několik doplňkových příkazů, které mohou být velice užitečné: 


\section{Nezařazené}

\setupfillinrules $[\ldots, . * *, \ldots]$

* width

= fit broad DIMENSION

distance

$=$ DIMENSION

before

$=$ COMMAND

after

$=$ COMMAND

style

$=$ normal

bold slanted boldslanted type cap small... COMMAND

$=$ NUMBER

interlinespace

separator

= small medium big

$=$ TEXT

$\backslash$ setupfillinlines $[\ldots, . \stackrel{*}{=} .,$.

* width $\quad=$ DIMENSION

margin $=$ DIMENSION

distance $=$ DIMENSION

before $=$ COMMAND

after $\quad=$ COMMAND

Uvedeme je v následujícím př́́kladu:

$\backslash$ setupfillinrules [width $=2 \mathrm{~cm}$ ]

$\backslash$ setupfillinlines [width $=3 \mathrm{~cm}$ ]

$\backslash$ fillinrules $[n=1]\{\backslash$ bf jméno\}

$\backslash$ fillinrules $[n=3]\{\backslash$ bf adresa $\}$

$\backslash$ fillinline\{Uved'te prosím \underbar\{počet\} domů v Hasseltu.\} \par

V tomto textu přeškrtněte loverstrikes\{Hasselt\}\periods[18]

Výsledkem bude:

jméno

37

adresa

Uved'te prosím počet domů v Hasseltu.

V tomto textu přeškrtněte Hasselt................

Tyto př́kazy bývají používány v dotaznících. Omezením je, že podtržený nebo přeškrtnutý text nebude na konci řádky rozdělen.

\subsection{Horní a dolní index v textu}

Vložit horní index a dolní index do dokumentu je jednoduché. A co říkáte tomuto: horní index dolní index To vypadá podivně, co?! 


\section{Nezařazené}

Tento ošklivý text byl vysázen pomocí \low\{\}, \high\{\} a \lohi\{\}\{\}. Index je vkládán do složených závorek.

\subsection{Datum}

Systémové datum vložíme do textu pomocí

Icurrentdate

\subsection{Umístění do předepsané polohy}

Občas máme potřebu umístit text na konkrétní místo uvnitř strany či jiného textového elementu. Uděláme to pomocí

$\backslash$ position $(\ldots, \ldots)\{.2$.

1 POSITION

2 TEXT

Kulaté závorky určují souřadnice $x, y$, složené závorky ohraničují text, který má být umístěn. Souřadnice nastavíme pomocí

\setuppositioning $[\ldots, . . *, \ldots]$

* state $=$ start overlay

unit $=\mathrm{cm}$ pt em $\mathrm{mm}$ ex es in

factor $=$ NUMBER

scale $=$ NUMBER

offset $=$ yes no

xstep = absolute relative

ystep $=$ absolute relative

Zvolit můžeme jednotky a měřítko. Zde je ilustrační př́́klad:

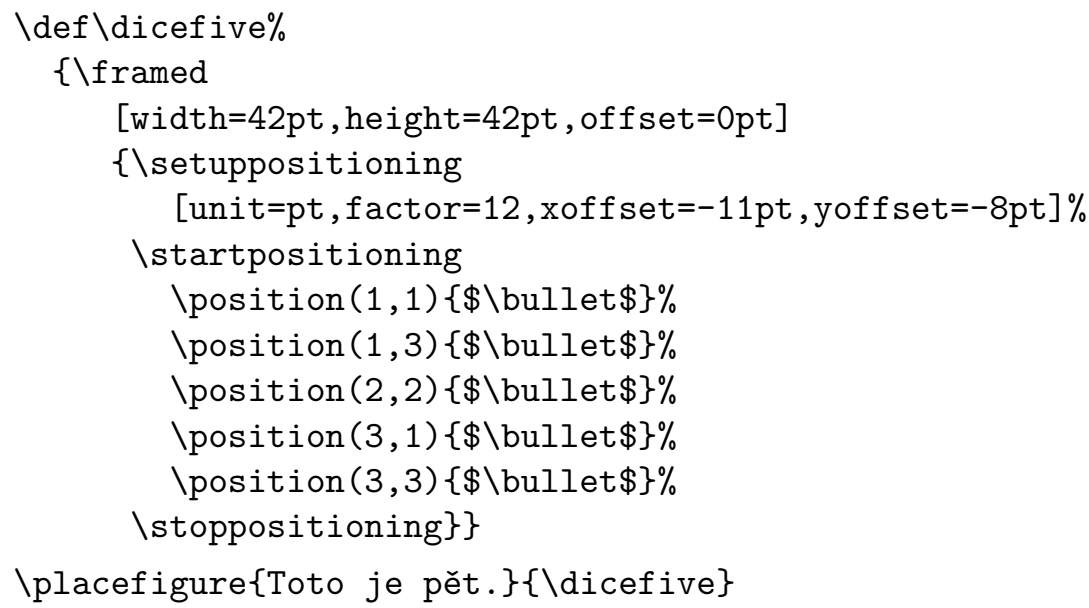

Výsledkem tohoto relativně složitého příkladu je toto: 


\section{Nezařazené}

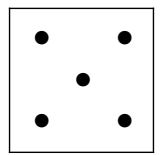

Obrázek 37.1 Toto je pět.

\subsection{Otočení textu, obrázků a tabulek}

V mnoha případech chceme otočit text nebo obrázek. Provedeme to pomocí

\rotate $[\ldots \underset{\text { OPTIONAL }}{.} ., \ldots]\{.2$.

1 inherits from \setuprotate

2 TEXT

Hranaté závorky jsou volitelné. Uvnitř nich specifikujeme úhel natočení: rotation=90. Složené závorky vymezují text či objekt, který chceme otočit. Příklad:

V roce 1252 Hasselt získal městská práva. Od té doby měl

\rotate[rotation=90] \{právo\} používat vlastní pečet na oficiálních

dokumentech. Tato pečet’ zobrazuje svatého Štěpána, jednoho z prvních

křest’anským mučedníků. Byl \rotate[rotation=270] \{patronem\}

Hasseltu. Po reformaci byla pečet pozměněna, svatý Štěpán ztratil svou svatost a byl zobrazován bez svatozáře.

Výsledkem je velice ošklivý odstavec:

V roce 1252 Hasselt získal městská práva. Od té doby měl : dokumentech. Tato pečet' zobrazuje svatého Štěpána, jednoho z prvních křest'anským mučední-

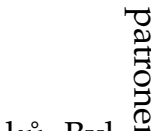<smiles>C1CCCCC1</smiles>
zobrazován bez svatozáře.

37 Stejně jednoduše můžeme otočit i obrázek:

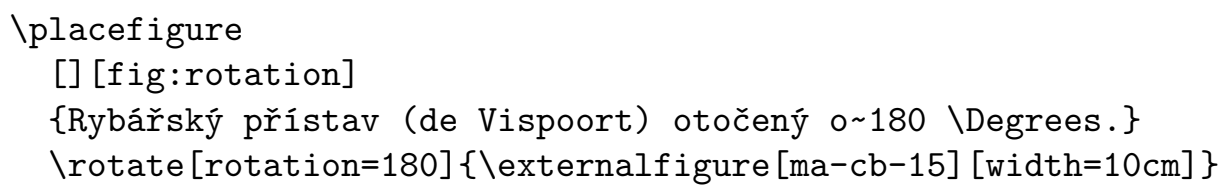

Na obrázku 37.2 vidíte, že není vždy úplně zřejmé, na co se díváme, když obrázek otočíme.

Otočení nastavíme pomocí: 


\section{Nezařazené}

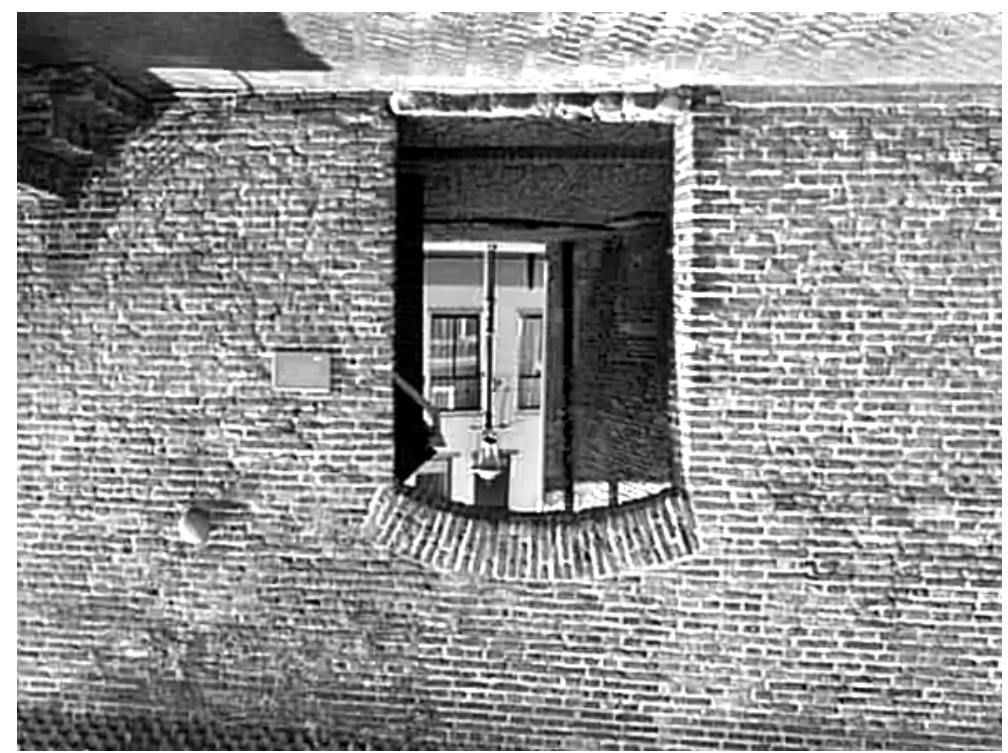

Obrázek 37.2 Rybářský přístav (de Vispoort) otočený o 180.

\setuprotate $[\ldots, . * *, \ldots]$

$*$ rotation $=$ NUMBER

location = normal high fit broad depth

inherits from \setupframed

\subsection{Ukončení řádky}

Nová řádka může být vynucena př́kazem

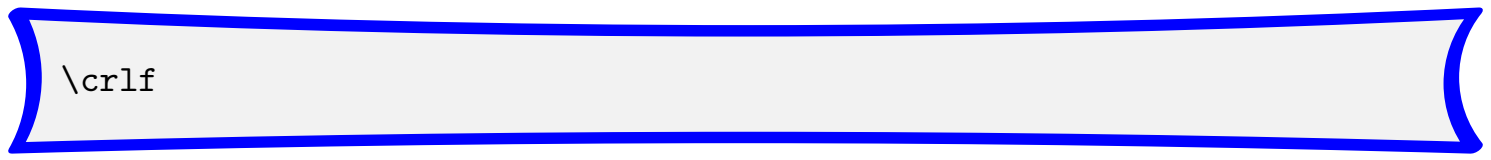

Pokud chceme, aby konce řádek kopírovaly ukončení ve vstupním souboru, napíšeme:

\startlines ... \stoplines

Na radnici města Hasselt je dřevěná deska, kde se můžeme dočíst:

Istartlines

Heimelijcken haet

eigen baet

jongen raet

Door diese drie wilt verstaen

is het Roomsche Rijck vergaen.

\stoplines 


\section{Nezařazené}

Tato malá básnička obsahuje varování pro radní Hasseltu: \{ \it Nedovol, aby osobní prospěch nebo pocity ovlivňovaly tvůj rozum při rozhodování.\}

Na radnici města Hasselt je dřevěná deska, kde se můžeme dočíst:

Heimelijcken haet

eigen baet

jongen raet

Door diese drie wilt verstaen

is het Roomsche Rijck vergaen.

Tato malá básnička obsahuje varování pro radní Hasseltu: Nedovol, aby osobní prospěch nebo pocity ovlivňovaly toůj rozum při rozhodování.

V několika prŕíkazech se konce řádků označují \\. Například když napíšeme

\inmargin\{uvnitř \\marginálie\}, pak se text v marginálním sloupci zlomí do dvou řádků.

\subsection{Dělění slov}

Pokud připravujeme vícejazyčný text, musíme si být vědomi faktu, že dělení slov se jazyk od jazyku liší.

Hlavní jazyk aktivujeme pomocí

$\backslash$ mainlanguage $[. *$. .

nl fr en uk de es cz ..

Mezi závorky můžeme vložit af (afrikánština), ca (katalánština), cn (čínština), cz (čeština), da (dánština), de (němčina), en (angličtina), es (španělština), fi (finština), fr (francouština), gr (řečtina), it (italština), hu (mad'arština), hr (srbochorvačtina), ja (japonština), nl (holandština), no (norština), pl (polština), pt (portugalština), ro (rumunština), ru (ruština), sk (slovenština), sl (slovinština), sv (švédština), tr (turečtina), ua (ukrajinština), uk (britská angličtina), us (americká angličtina) a vn (vietnamština).

K dočasné změně jednoho jazyka na jiný použijeme kratší variantu:

$\backslash$ language [en]

nebo

$\backslash$ en

Např́klad:

Pokud se chcete dozvědět více o Hasseltu, asi nejlepší knihou, kterou si můžete přečišt, je $\{\backslash n l \backslash e m$ Uit de geschiedenis van Hasselt\} od F. Peerebooma.

Pokud se chcete dozvědět více o Hasseltu, asi nejlepší knihou, kterou si můžete přečíšt, je Uit de geschiedenis van Hasselt od F. Peerebooma.

Pokud je slovo rozděleno nesprávně, můžeme si dodefinovat místo rozdělení sami. Uděláme to v úvodní části dolumentu takto: 
\hyphenation\{his-to-rie\}

\subsection{Komentář ve zdrojovém souboru}

Veškerý text mezi \starttext a \stoptext bude CONTEXTem zpracován. Někdy se však vyskytne fragment textu, který zpracovávat nechceme, nebo chceme okomentovat př́kazy CONTEXTu.

Pokud předřadíme našemu textu znak procenta \%, nebude zpracován.

\% Ve velmi velkém dokumentu můžeme zdrojový text vložit

$\%$ z externích souborů.

$\%$

\% Například:

$\%$

$\%$ \input hass01.tex \% kapitola 1 o Hasseltu

$\%$ \input hass02.tex \% kapitola 2 o Hasseltu

$\%$ \input hass03.tex \% kapitola 3 o Hasseltu

Pokud před každým př́kazem \input smažeme znak \%, soubory budou zpracovány. Komentár̆ popisující obsah souborů zpracován nebude.

\subsection{Vstup jiného zdrojového tex souboru}

V mnoha situacích chceme do svého zdrojového souboru vložit jiný soubor TEX. Někdy je např́íklad efektivnější rozdělit text psaný v CONTEXTu do více souborů, aby mohly být zpracovány samostatně.

Soubor se jménem jiny . tex může být vložen pomocí:

\input jiny.tex

Př́pona tex je nepovinná, takže bude fungovat i

\input jiny

Př́kaz \input je primitivum TEXu.

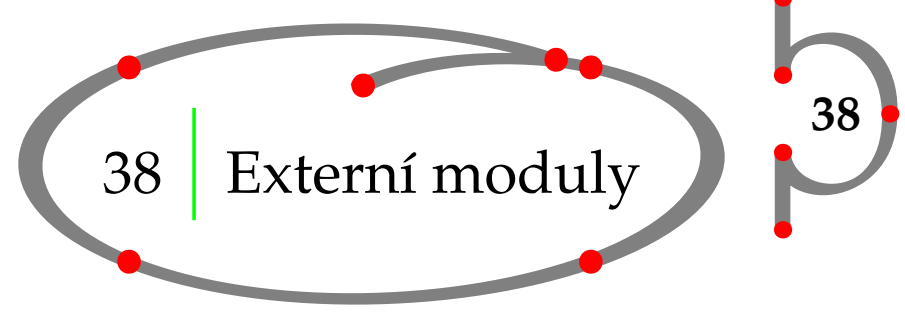

Kvůli efektivnosti se autor rozhodl realizovat některé funkce CONTEXTu prostřednictvím vnějších modulů. Můžeme například zavést následující moduly: ${ }^{11}$

- bib sazba bibliografických referencí programem BIBTEX;

- chemic sazba chemických struktur;

11 Více viz seznam modulů na http:/ / wiki.contextgarden.net/Modules. 
Externí moduly

- units použití jednotek SI;

- pictex kreslení obrázků (používá se společně s modulem chemic);

- chart náčrt vývojových diagramů a organizačních schémat;

- steps náčrt stavových diagramů;

- narrowtt použití užšího strojopisu Computer Modern pro verbatim prostředí;

- amsl implementace AMSmath příkazů;

- nath přirozená sazba matematiky, obsahuje modul amsl;

- streams synchronizace několika vstupních textů (dvojjazyčná sazba);

- gnuplot přímý zápis GNUPLOT grafů;

- lilypond sazba notových osnov programem LilyPond.

Zavedení se provede v deklarační oblasti příkazem:

\usemodule $[\ldots, \ldots . .$.

* IDENTIFIER

Již jsme uvedli množství př́íkladů použití modulu units. Níže bez dalšího vysvětlení uvádíme dva příklady použití modulů chemic a chart. Tyto moduly jsou popsány ve dvou samostatných př́ručkách (http:/ / wwww.pragma-ade.com/general/manuals/mp-ch-en.pdf, http://www. pragma-ade.com/general/manuals/mcharts.pdf).

Chemické struktury mohou vypadat velice působivě:<smiles>CC(=O)C1=C(C)C(C(C)=O)NC=C1C</smiles>

Sloučenina A

Při kreslení chemických struktur tohoto typu se CONTEXT spoléhá na METAPOST. Třebaže jsou tyto chemické struktury definovány jenom pomocí dvou nebo tří příkazů, na získání správných výsledků je potřebná jistá praxe. Vstup může vypadat takto:

$\backslash$ placeformula [-]

Istartformula

Istart chemical [scale=small, width=fit, top=3000, bottom=3000]

\chemical [SIX , SB2356, DB14, Z2346, SR3, RZ3, -SR6 ,+SR6, -RZ6 ,+RZ6]

$[\mathrm{C}, \mathrm{N}, \mathrm{C}, \mathrm{C}, \mathrm{H}, \mathrm{H}, \mathrm{H}]$

\chemical [PB : Z1, ONE, ZO, DIR8, Z0, SB24,DB7 , Z27, PE] [C, C, CH_3 ,0]

\chemical [PB : Z5, ONE, ZO, DIR6, ZO, SB24, DB7 , Z47 , PE] [C, C, H_3C , O]

$\backslash$ chemical [SR24,RZ24] [CH_3,H_3C]

bottext $\{$ Sloučenina $A\}$

\stopchemical

\stopformula 
Externí moduly

Modul chart si představíme ukázkou definice organizačního schématu. Může vypadat následovně:

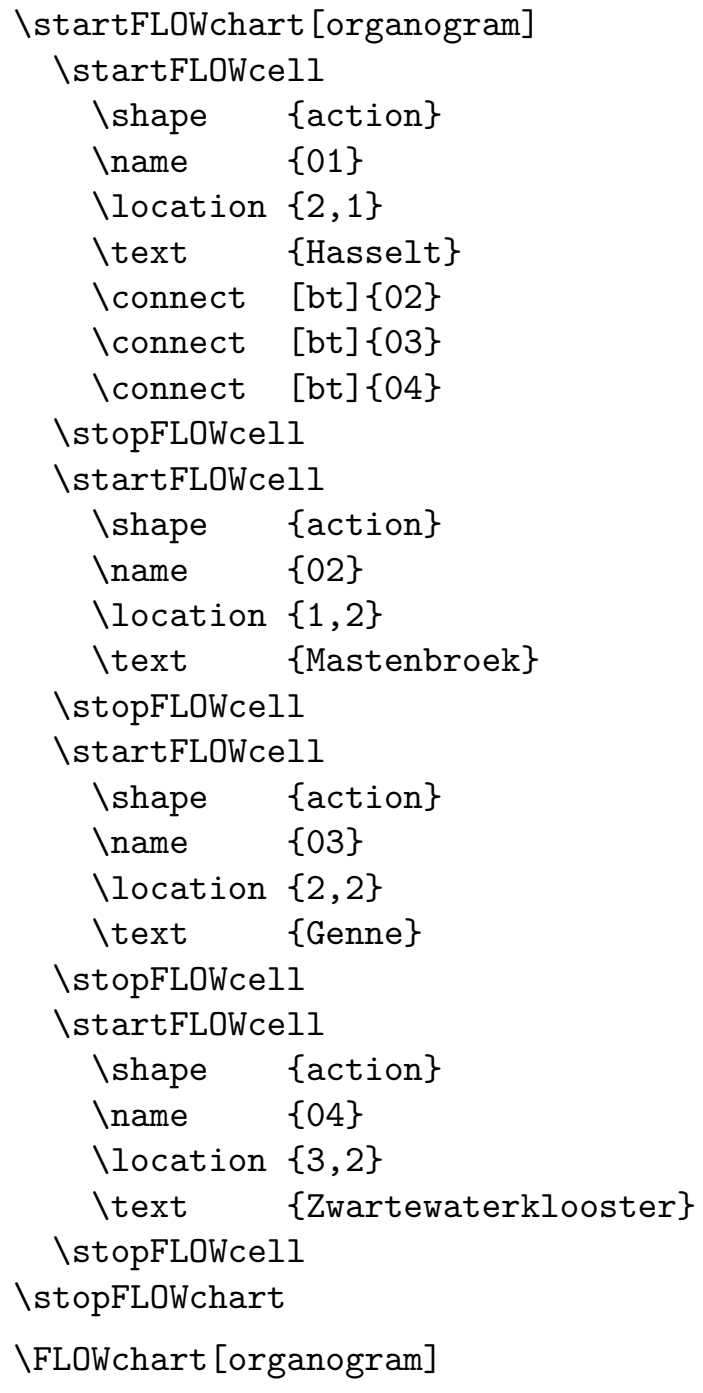

Výsledkem bude: 

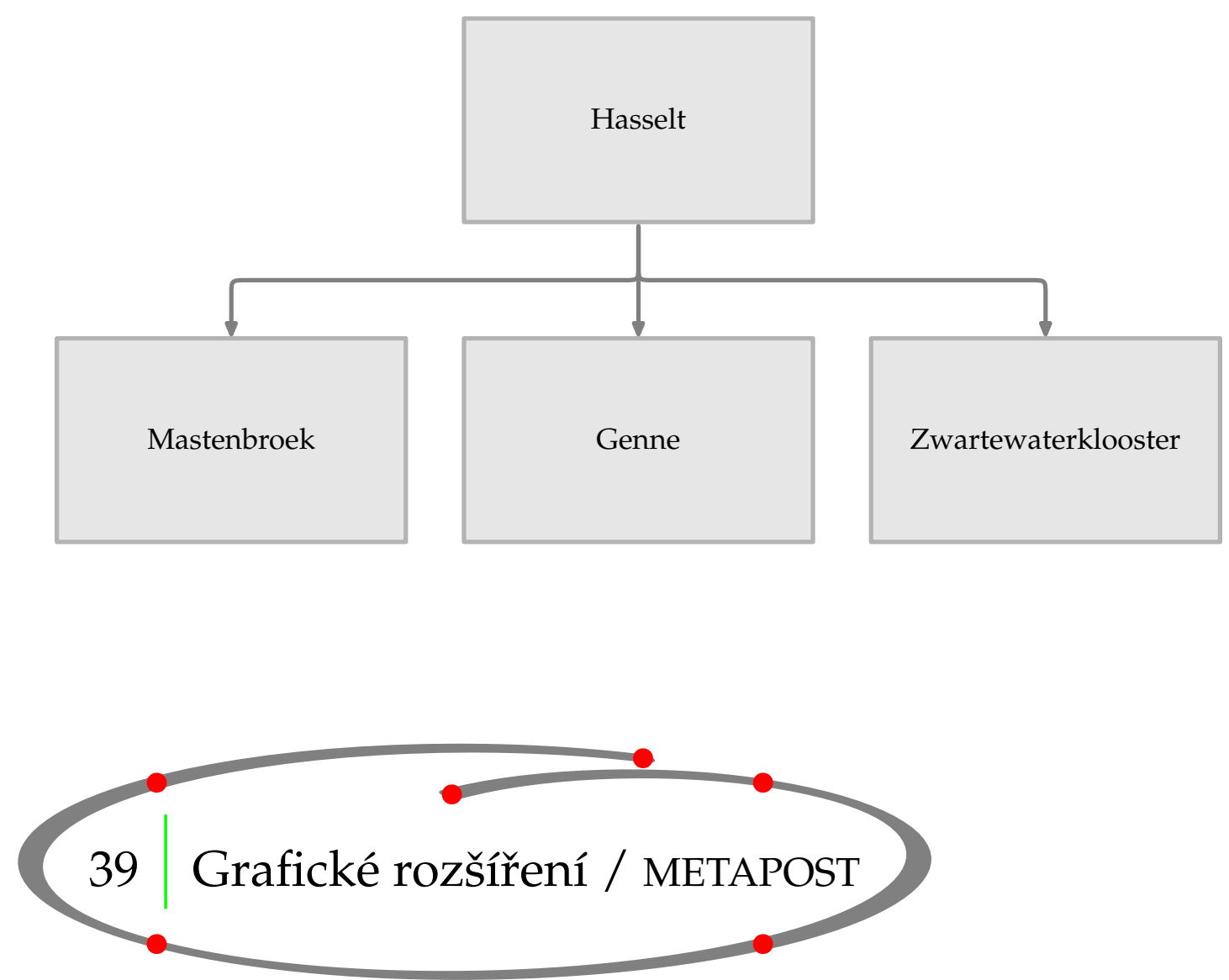

Grafické možnosti makrojazyka TEXu jsou dosti omezené. Použijeme-li však grafický systém METAPOST od Johna Hobbyho, získáme úplnou množinu grafických prvků, které mohou zlepšit vzhled našeho dokumentu.

CONTEXT přímo spolupracuje s METAPOSTem, takže uživatel může využít všechny vlastnosti METAPOSTu př́mo ve svém dokumentu. Nadpisy kapitol a čísla stránek tohoto manuálu jsou zvýrazněny grafikou př́ímo generovanou METAPOSTem.

Použití METAPOSTu v CONTEXTu je popsáno v rozsáhlém manuálu http://www.pragma-ade.com /general/manuals/metafun-s.pdf. 


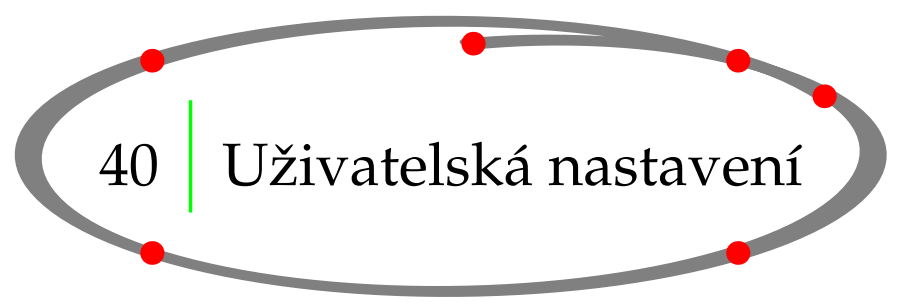

Během provozu CONTEXTu se nastavuje množství implicitních parametrů. Tyto parametry jsou zadefinovány v souboru cont-sys . tex. Uživatelé mohou tento soubor vytvořit přejmenováním souboru cont-sys .rme (nejlépe ve stejném adresáři, aby jej CONTEXT našel) a v tomto souboru definovat své vlastní preference (firemní styl). Nejdůležitějš́ část tohoto souboru se pravděpodobně týká výstupu:

\setupoutput [pdftex]

Sdělí CONTEXTu, že má vytvářet výstup PDF namísto DVI, zatímco

\setupoutput [dvipsone, dviwindo]

nastaví podmínky pro tyto programy. Předvolený je DVIPS výstup.

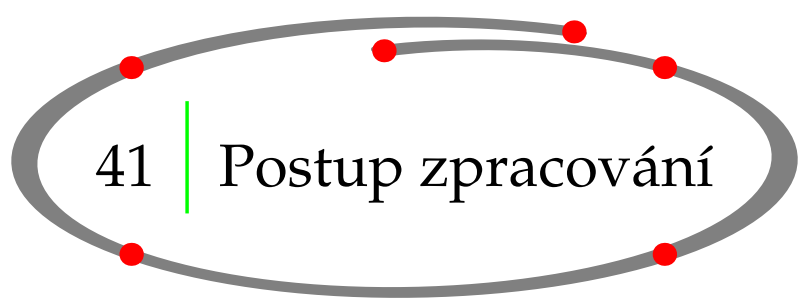

Během zpracování zapisuje CONTEXT informace do souboru mujsoubor.tui. Tyto informace se využívají v následujícím průchodu. Část těchto informací je zpracována programem TEXUTIL. Informace o registrech a seznamech se jím převede do souboru mujsoubor. tuo. CONTEXT filtruje informace $\mathrm{z}$ tohoto souboru a (v príípadě potřeby) je využívá.

Program TEXUTIL umí další užitečné činnosti. Obecný zápis pro použití tohoto programu je: ${ }^{12}$

texmfstart texutil --specifikace jmeno_souboru

Velikosti všech vektorových i bitmapových obrázků (boundingbox) v zadaném adresáři vypíšeme do souboru texutil. tuf zadáním:

texmfstart texutil --figures *.*

Pokud potřebujeme konvertovat EPS-ilustrace do formátu PDF, můžeme zadat:

texmfstart texutil --figures --epspage --epspdf

Dočasné soubory (.tui, .tuo, *-mpgraph.*, ap.) smažeme

12 Některé funkce v době překladu tohoto manuálu mohl převzít program ctxtools. 


\section{Pomocné soubory}

texmfstart texutil --purge

nebo novější

texmfstart ctxtools --purgefiles

a všechny generované soubory v aktuálním adresáři smažeme pomocí

texmfstart texutil --purgeall

nebo

texmfstart ctxtools --purgefiles --all

Informace o přetečených nebo podtečených boxech a neznámých referencích odfiltrujeme ze záznamového souboru o běhu CONTEXTu (.log) př́íkazem

texmfstart texutil --logfile soubor.log

Na spuštění CONTEXTu používáme povel TEXEXEC:

texmfstart texexec jmeno_souboru

Tento program se postará o to, aby se CONTEXT spustil tolikrát, kolikrát je potřeba pro získání správných odkazů. Zvláštní požadavky můžeme zadat také přímo v příkazové řádce. Například, když je požadován výstup ve formátu pdf, napíšeme:

texmfstart texexec --pdf jmeno_souboru

Když jsme na pochybách, můžeme se na parametry programů dotázat přepínačem --help. K dispozici je také dokumentace http:/ / www.pragma-ade.com/general/manuals/mtexexec.pdf a http://www.pragma-ade.com/general/manuals/mtexutil.pdf.

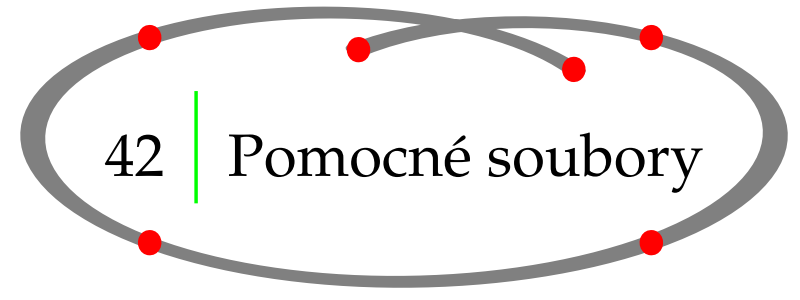

42 V průběhu zpracování vytváří CONTEXT množství pomocných souborů. Pokud název vstupního souboru je muj soubor . tex, v pracovním adresáři se objeví následující soubory: 


\begin{tabular}{lll}
\hline Soubor & Obsah & Stav \\
\hline mujsoubor.tex & vstupní text & neodstraňujme \\
\hline mujsoubor.tui & vstupní informace & může být odstraněn \\
mujsoubor.tuo & výstupní informace & neodstraňujme \\
mujsoubor.tub & informace o blocích & neodstraňujme \\
mujsoubor.tmp & dočasné informace & múže být odstraněn \\
\hline texutil.tuf & informace o obrázcích & vytvořme v př́ípadě potřeby \\
mpgraph.mp & informace METAPOSTu & může být odstraněn \\
\hline mujsoubor.dvi & vysázený text & může být odstraněn \\
mujsoubor.ps & text k tisku & může být odstraněn \\
mujsoubor.pdf & text k tisku/prohlížení & může být odstraněn \\
\hline
\end{tabular}

\subsection{Minimální český/slovenský dokument}

Pro sazbu českých nebo slovenských textů nám stačí základní formát cont-en ${ }^{13}$. Ten již obsahuje vzory dělení pro češtinu/slovenštinu v náležitých kódováních, o čemž se lze přesvědčit př́íkazem \showpatterns, viz tabulku 31.1.

Formát cont-en se všemi vzory dělení vygenerujeme př́kazem

texmfstart texexec --make --all

V samotném dokumentu musíme nastavit češtinu nebo slovenštinu jako hlavní jazyk: \mainlanguage [cz] / \mainlanguage [sk] a zvolit námi používané vstupní kódování. Minimální český dokument min-cz . tex v kódování ISO-8859-2 pak bude vypadat takto:

$\backslash$ mainlanguage [cz]

\enableregime [latin2]

13 Alternativou je lokalizovaný formát cont-cz s počeštěnými názvy uživatelských př́kazů. Tuto lokalizaci ConTEXtu vytvořil Tomáš Hudec v rámci své diplomové práce v roce 2001 pod vedením Petra Sojky. Protože je však dosud česká CONTEXTová komunita malá, česká dokumentace téměř žádná a terminologie př́ikazů neustálená a neúplná, používá se hlavně $\mathrm{z}$ důvodů kompatibility téměř výhradně anglické rozhraní cont-en. Toto anglické rozhraní popisuje i tento manuál. 


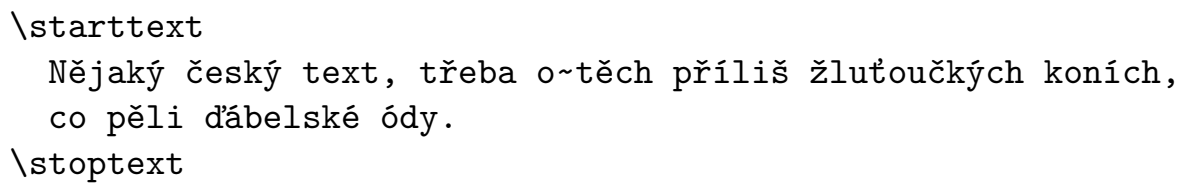

Pro minimální slovenský dokument pouze nahradíme $c z \longrightarrow$ sk. Soubor přeložíme do PDF (i s jeho automatickým zobrazením) prŕíkazem

texmfstart texexec --pdf --autopdf min-cz

\subsection{Písma}

CONTEXT implicitně používá písmo Latin Modern v kódování ec. ${ }^{14}$ Toto kódování obsahuje všechny znaky potřebné pro sazbu českých i slovenských textů. Výchozí nastavení písma je provedeno príkazy

$$
\begin{aligned}
& \text { \usetypescript [modern] [ec] } \\
& \text { \setupbodyfont [modern, 10pt,rm] }
\end{aligned}
$$

Pokud chceme tisknout kombinací

Times New Roman - Helvetica - Courier, nastavíme

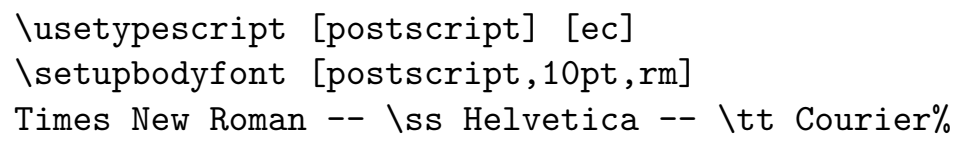

Množství dalších písem je definováno v souborech type-enc. tex a type-buy . tex.

Pro některá písma ze Štormovy písmolijny je též vytvořená podpora, viz adresu http:/ / modules. contextgarden.net/stormfontsupport s katalogem http://dl.contextgarden.net/modules/stormfontsupport/cont-storm-catalog.pdf. Pomocí ní je pak například užití písma Lido jednoduché:

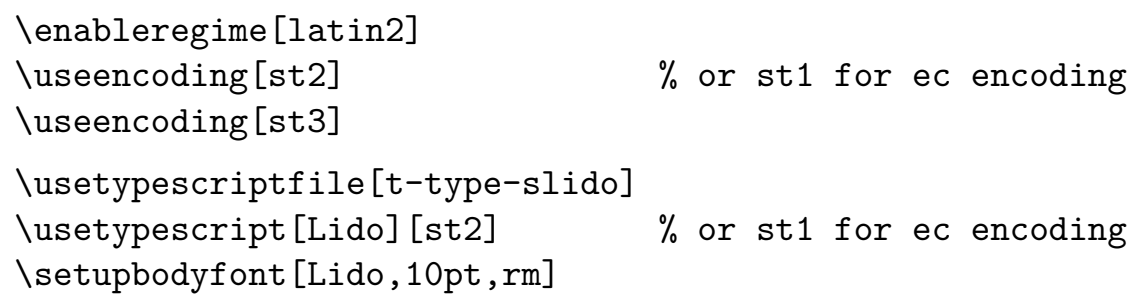

\subsection{Kódování}

Náš vstupní text vytváříme v určitém kódování, nejčastěji v ISO-8859-2 (Latin 2), CP1250 (Windows), či UTF-8. Protože tato tři kódování se většinou liší od kódování fontu (a vzorů dělení slov), je třeba CONTEXTu toto vstupní kódování sdělit. Potřebnou konverzi pak zařídí za nás.

Vstupní kódování se v CONTEXTu nazývá režim (regime). Jeho nastavení se provede pomocí \enableregime, tedy pro výše zmíněné kódování \enableregime [Latin2], \enableregime [cp1250] nebo \enableregime [utf8].

14 Pokud bychom potřebovali CSfonty, můžeme využít zakomentovaný kód souboru type-old.tex. 


\subsection{Uvozovky, pomlčky a spol}

Text „V uvozovkách“ a ,jednoduchých uvozovkách` se napíše pomocí \quotation\{...\} a \quote\{...\}. Pomlčka - ta se napíše pomocí $|<|$ a spojovník je-li na vstupu $|-|$. CONTEXT zařídí př́ípadné opakování na konci řádky. Francouská mezera za tečkou \frenchspacing je v ConTEXtu implicitní.

\subsection{Datum}

Máme-li hlavní jazyk cz, pak př́kazem \currentdate vysázíme 6. prosince 2006. Pokud lokálně přepneme do jiného jazyka

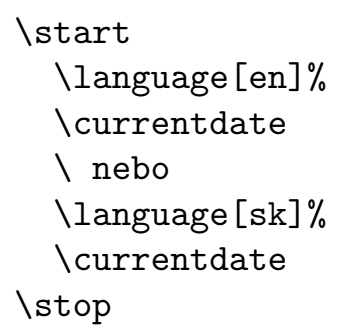

dostaneme December 6, 2006 nebo 6. decembra 2006. Z číselné informace získáme název měsíce $\backslash$ month $\{2\}$ (února) a název dne počínaje nedělí \weekday\{5\} (čtvrtek).

\subsection{Popisky a názvy}

Nastavením hlavního jazyka dostaneme patřičné názvy pro obrázky, tabulky, přílohy ap., viz soubor lang-sla.tex. Změnit název lze pomocí \setupheadtext, např.

\setupheadtext [cz] [content=Obsah průvodce po Hasseltu]

\section{7 Řazení}

CONTEXT obsahuje interní řadící a částečně konfigurovatelný algoritmus (soubor sortlan. tex $)^{15}$. Vychází se z normy ČSN 976030 z roku 1994, ale zatím nejde o její plnou implementaci; hlavní rozdílnost je v pořadí číslic, znaku apostrofu a spojovníku. Řazení využívají rejstř́iky (index) a řazené seznamy (sorting).

15 Slovenská sekce pravidel v tomto souboru zatím není napsaná. 
Sazba českých/slovenských textů 


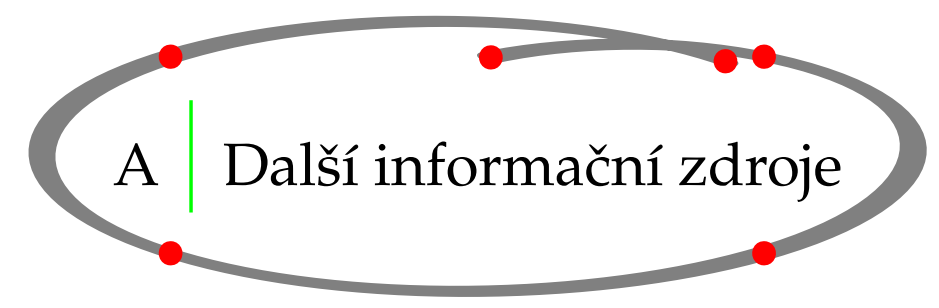

Už vám tento začátečnický manuál nedostačuje? Potřebujete poradit? Zajímá vás mnoho dalších možností CONTEXTu? Tato kapitola může pomoci v orientaci po dostupných informačních zdrojích. Bohužel - v češtině existuje zatím pouze tento manuál. Všechna ostatní zde doporučovaná literatura je v angličtině.

\section{A.1 CONTEXTová wikipedie}

CONTEXT vznikl v Holandsku a tak nepřekvapí, že jeho symbolem jsou tulipány. Internetové stránky http://wiki.contextgarden.net jsou zahradou, kde uživatelé doslova pěstují CONTEXT: sdílí své poznatky na principu wikipedie. Najdeme zde návody a řešení, referenční manuál (http: / / texshow.contextgarden.net), odkazy na užitečné informace, errata manuálů, ,živý‘ CONTEXT pro testování bez nutnosti domácí instalace, archiv velice živé konference - a to vše plně prohledávatelné.

\section{A.2 Manuály}

Uvádíme zde výběr nejzajímavějším manuálů z pera Hanse Hagena. Každý je originální ukázkou možností CONTEXTu. Úplný seznam čtenář najde na stránkách http:/ / www.pragma-ade.com nebo přímo v adresáři http://www.pragma-ade.com/dir/general.

CONTEXT the manual (http:/ / www.pragma-ade.com/general/manuals/cont-eni.pdf)

Základní manuál CONTEXTu. Všeobecný a hluboký zdroj informací, byt' poměrně staršího data (2001).

METAFUN (http:/ / www.pragma-ade.com/general/manuals/metafun-s.pdf) Zevrubný manuál o grafických možnostech CONTEXTu založený na integraci METAPOSTu. (2002)

Fonts in CONTEXT (http://www.pragma-ade.com/general/manuals/mfonts.pdf) Instalace nových fontů. (2001)

Widgets uncovered (http:/ / www.pragma-ade.com/general/manuals/mwidget.pdf) Použití interaktivních prvků v PDF: hyperlinky, videa, formuláře, Java script. (2001)

XML in CONTEXT (http:/ / www.pragma-ade.com/general/manuals/xmlcontext.pdf) Př́má sazba z XML zdrojových textů. (2001)

BIBTEXový modul (http:/ / www.pragma-ade.com/general/manuals/bibmod-doc.pdf) Popis použití modulu pro BIBTEX.

Columns (http:/ / www.pragma-ade.com/general/manuals/columns.pdf)

Vícesloupcová sazba včetně plavajících objektů, sazba do řádkového rejstříku, sazba obrázků přes několik stránek. (2004) 


\section{Další informační zdroje}

Natural Tables in CONTEXT (http://www.pragma-ade.com/general/manuals/enattab.pdf) Alternativní sazba tabulek s podobnou syntaxí jako v HTML. Vhodné pro sazbu tabulek z XML, s barevným pozadím, nepravidelnou velikostí buněk a dlouhých tabulek přes několik stránek. (2004)

Charts uncovered (http://www.pragma-ade.com/general/manuals/mcharts.pdf) Vývojové diagramy v pravidelné mřížce buněk. (2001)

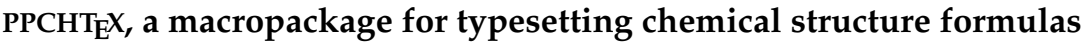
(http://www.pragma-ade.com/general/manuals/mp-ch-en.pdf) Sazba chemických struktur a diagramů. (2001)

Adding Text to Graphics (http://www.pragma-ade.com/general/manuals/mlabels.pdf) Přidání popisků do obrázků. (2002)

It's in the Details (http://www.pragma-ade.com/general/manuals/details.pdf) Popis různých triků: dodržení řádkového rejstř́ku, pseudosloupce, barevné pozadí či rámy i přes několik stránek, usazení matematických rovnic, umístění plavajících objektů, popisky obrázků. (2004)

Typographic Programming (http://www.pragma-ade.com/general/manuals/style.pdf) Rozpracovaný manuál o typografii v CONTEXTu. (2005)

\section{A.3 Magazíny}

Magazínem se v této komunitě myslí ukázkový dokument $\mathrm{s}$ jednotnou úpravou zaměřených na nějaké téma. Existují dva druhy. První ,This way' je psán samotným tvůrcem CONTEXTu Hansem Hagenem, druhý ,My way’ je psán jednotlivými uživateli. Jako ukázky uved'me:

Good looking shapes (http:/ /www.pragma-ade.com/general/myway/mag-0010.pdf)

Sazba do definovaného tvaru odstavce.

Using \startalign and friends

(Aditya Mahajan, http://www.pragma-ade.com/general/myway/mathalign.pdf) Sazba matematických rovnic a jejich zarovnávání.

\section{Natural Tables}

(Willi Egger, http://www.pragma-ade.com/general/myway/NaturalTables.pdf) Ukázka použití, přirozených tabulek'.

\section{A.4 Instalace}

A Čerstvý CONTEX čtenár̆ nalezne na stránkách firmy Hanse Hagena http:/ / wwww.pragma-ade.com (Advanced Document Engineering). Většinou se vyplatí instalovat nejnovější beta verzi. K dispozici jsou samostatné instalace pro různé operační systémy nebo balíky do stávající distribuce $\mathrm{T}_{\mathrm{E} X u} \mathrm{~V}$ takovém případě instalace spočívá $\mathrm{v}$ rozbalení cont-tmf .zip do patřičného $\mathrm{T}_{\mathrm{E}} \mathrm{X}$ stromu a v přegenerování formátu (viz kapitolu 43). 


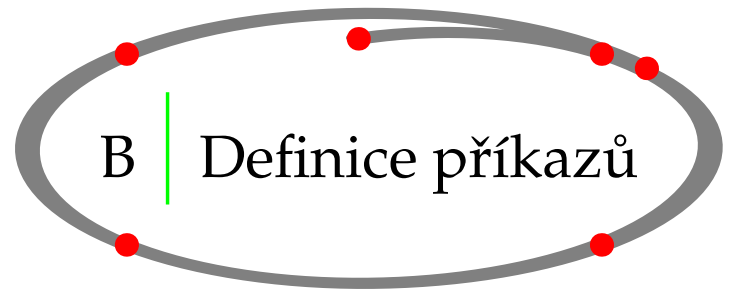

Následuje souhrn př́ikazů, jež jsme uvedli v předchozích kapitolách. Je to jen výběr z celého repertoáru příkazů CONTEXTu. Kdo je chce uvidět všechny, mưže nahlédnout do rozsáhlejší příručky CONTEXT the manual (http:/ / www.pragma-ade.com/general/manuals/cont-eni.pdf) nebo do online referenčního manuálu (http://texshow.contextgarden.net), poskytujících úplný přehled uživatelských příkazů CONTEXTu. Vysvětlení použité syntaxe je podáno v kapitole 35.

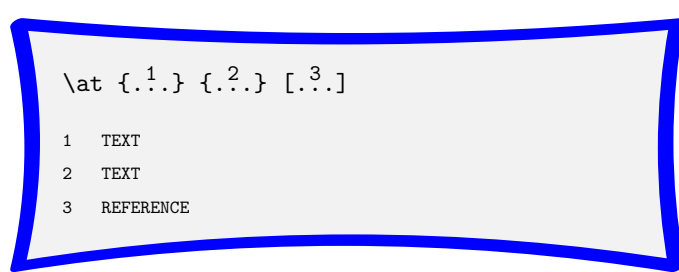

$\backslash$ blank $\underset{\text { OPTIONAL }}{[\ldots * \ldots]}$ * small medium big nowhite back white disable
force reset line halfline ForMULA fixed flexible none
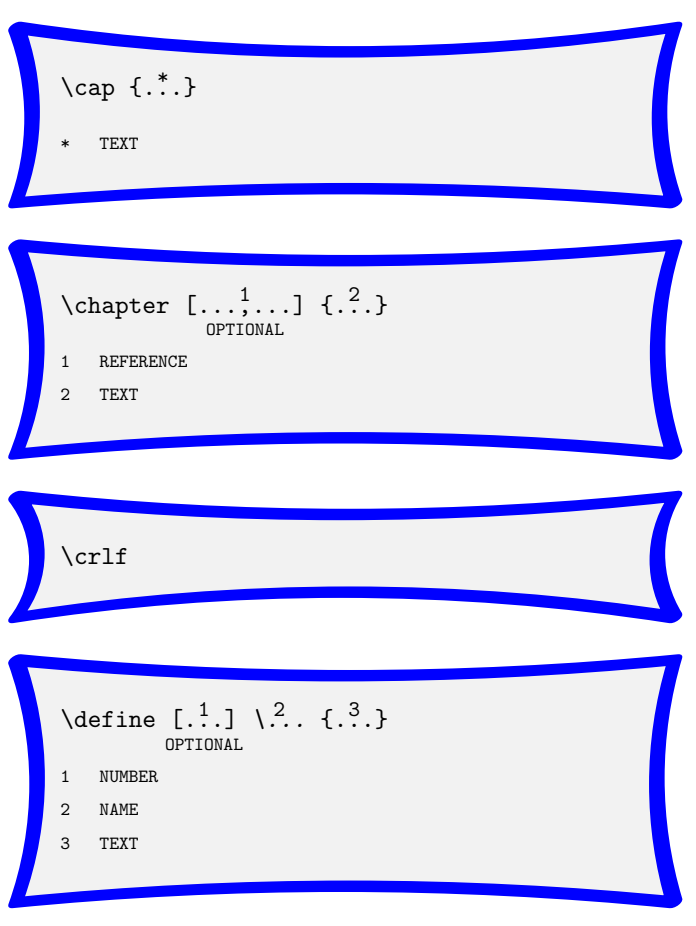
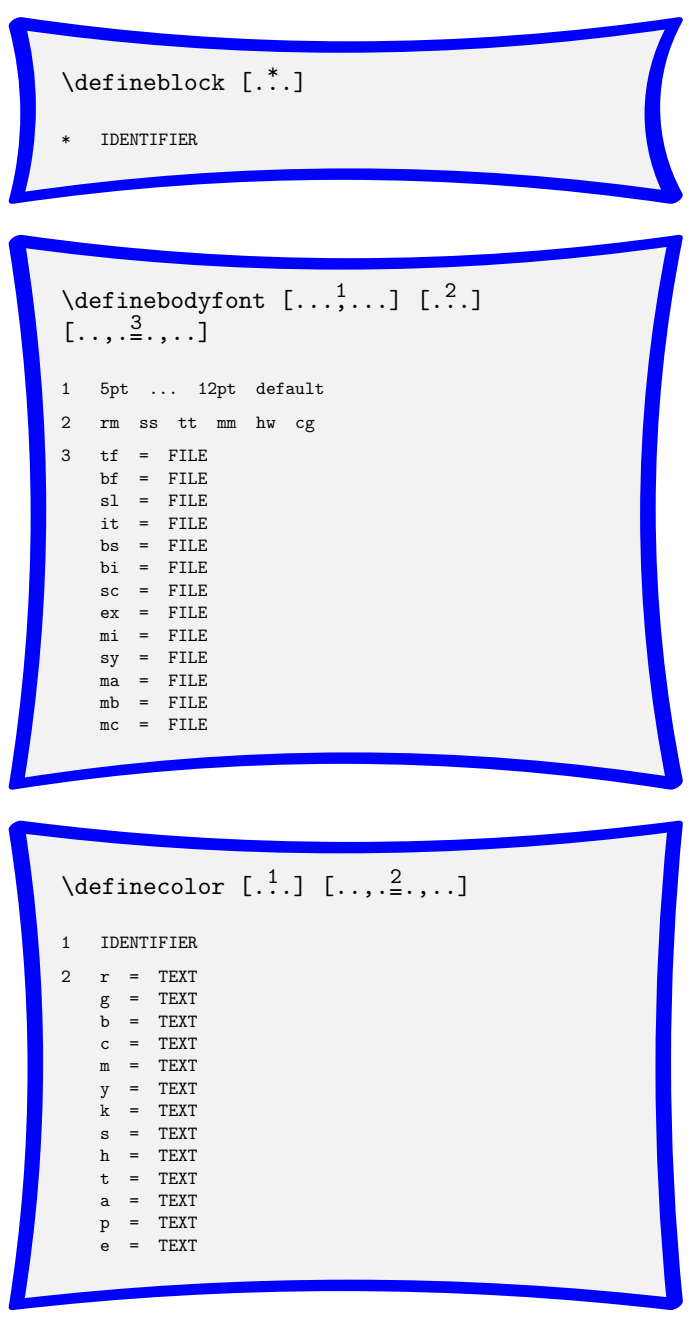

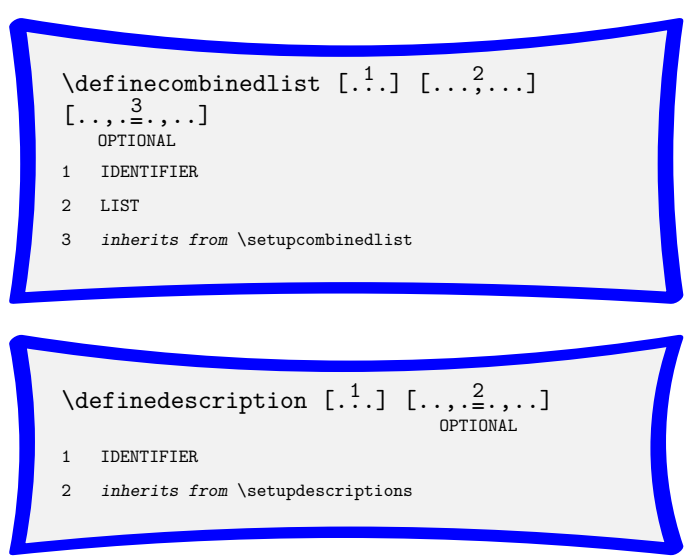

$\backslash$ defineenumeration $[\ldots, \ldots] \quad\left[{ }^{2}.\right]$

$[\ldots, . \stackrel{3}{.}, \ldots]$

OPTIONAL

1 IDENTIFIE

2 IDENTIFIER

3 inherits from \setupenumerations

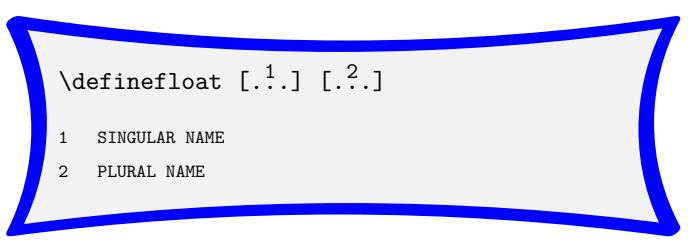

\definehead [.. . . [. 2. . ]

1 IDENTIFIER

2 SECTION

Idefineinteractionmenu $[.1] \quad.[\ldots, \ldots]$

$[\ldots, . \stackrel{3}{=} ., \ldots]$

IDENTIFIER

2 left right top bottom IDENTIFIER

3 before $=$ COMMAND

after $\quad=$ COMMAND

inbetween $\quad=$ COMMAND

left

right

middle

state

style

color

distance

samepage

unknownref er

leftoffset

rightoffset
topoffset

topoffset
bottomoffset

position

position

$=$ COMMAND

$=$ COMMAND

= COMMAND

start stop none local

normal bold slanted

boldslanted type cap small.

COMMAND

IDENTIFIE

overlay DIMENSION

yes empty no none

yes empty no none

DIMENSION

$=$ DIMENSION

$=$ DIMENSION

yes no

upframed

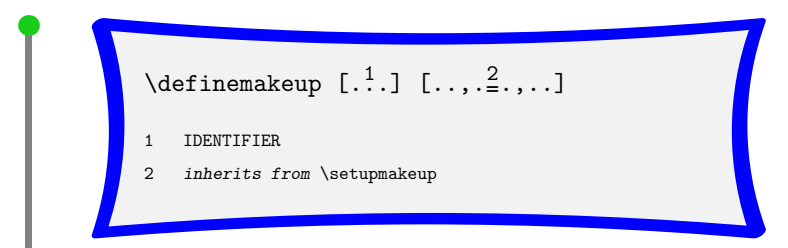

\defineregister [.. . . [.2.]

1 Singular Name

2 PLURAL NAME
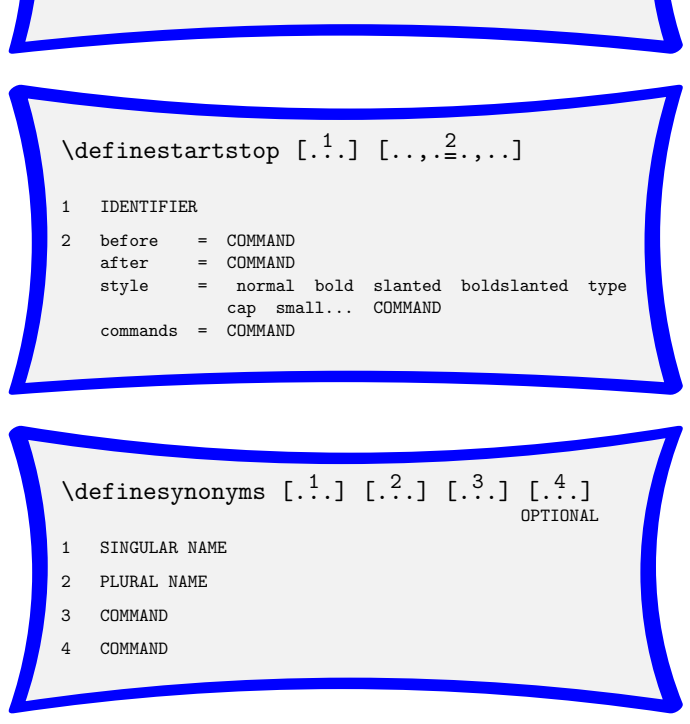

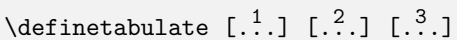

OPTIONAL OPTIONAL

1 IDENTIFIER

2 IDENTIFIER

TEXT

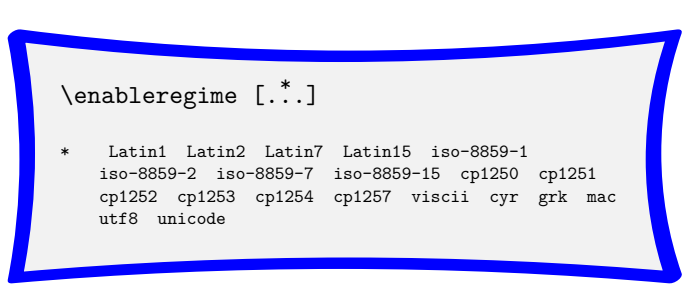

lexternalfigure $[.1 .].[\ldots, .2 ., \ldots]$

1 FILE

2 inherits from luseexternalfigure 

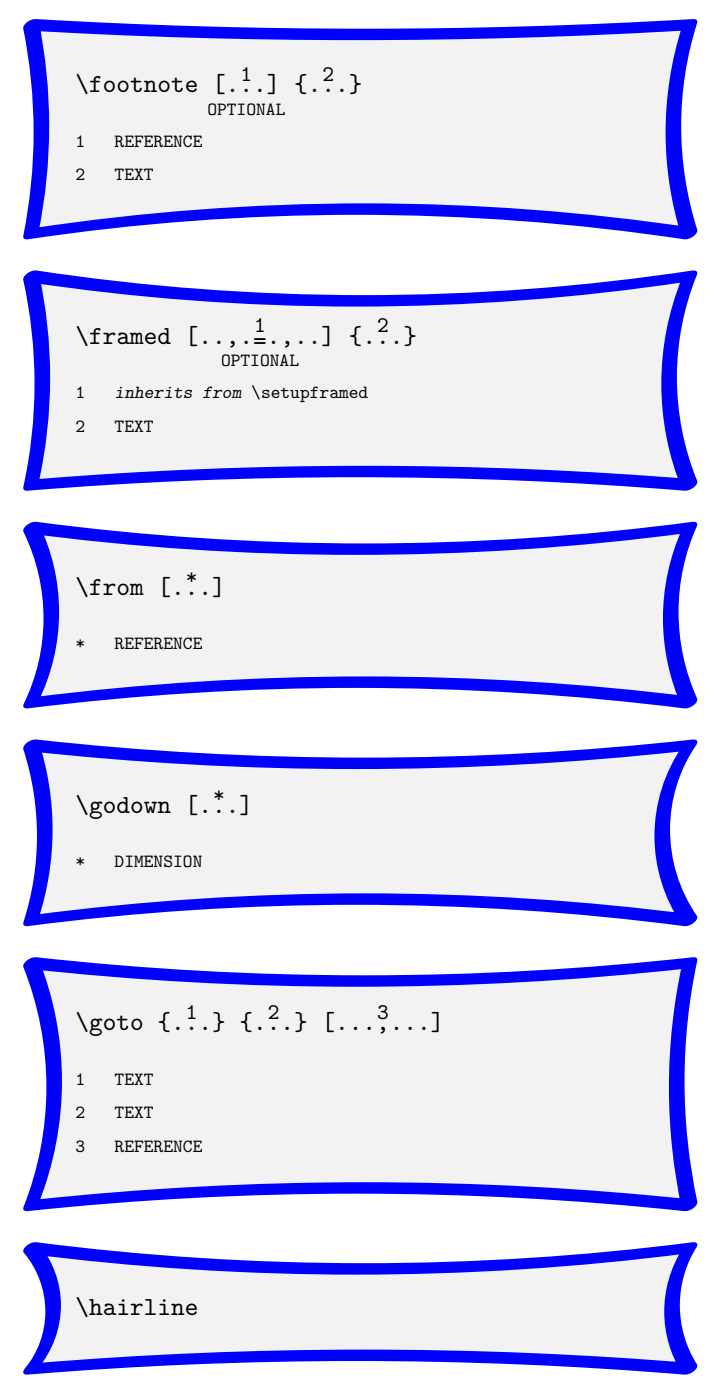

$\backslash$ hideblocks $[\ldots, \ldots][\ldots, \ldots]$

1 IDENTIFIER

2 IDENTIFIER
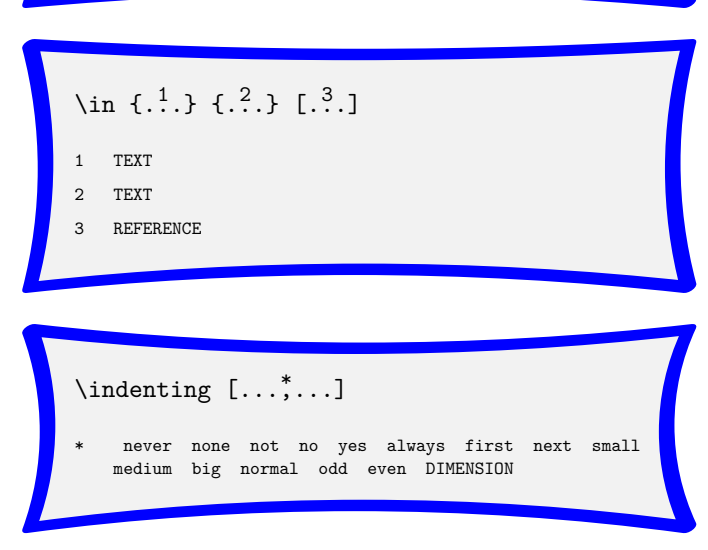

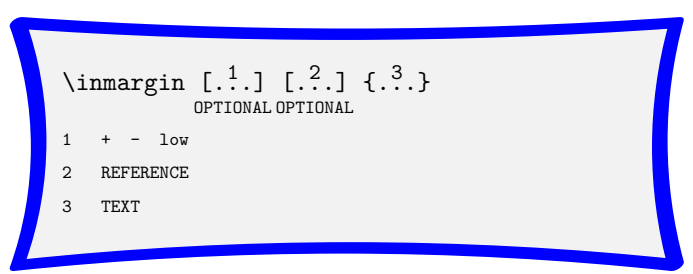

$\backslash$ keepblocks $[\ldots, \ldots] \underset{\text { OPTIONAL }}{[\ldots 2, \ldots]}$

1 IDENTIFIER

all IDENTIFIER
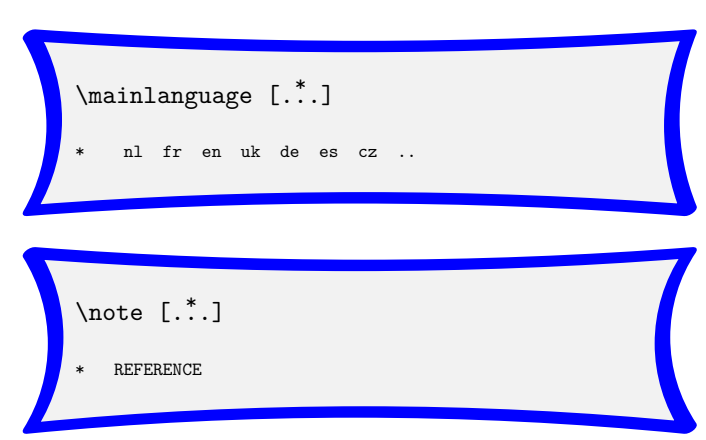

\page $[\ldots, \ldots]$

* yes makeup no preference bigpreference left yes makeup no preference bigpreference left empty reset start stop

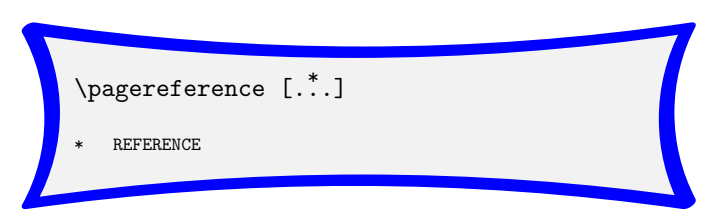

$\backslash$ placefloat $\underset{\text { OPTIONAL }}{[.1 .]}[\ldots, \ldots]\}\{.3\}.\{\{.4\}$.

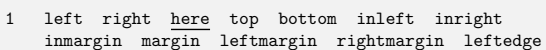
inmargin margin leftmargin rightmargin lefted
rightedge innermargin outermargin inneredge

rightedge innermargin outermargin inneredge
outeredge inner outer line high low fit page

outeredge lnner outer line high low fit page
leftpage rightpage opposite always auto force

tall reset line height depth split

2 REFERENCE

3 TEXT

$4 \quad$ TEXT

$\backslash$ placefootnotes $\underset{\text { OPTIONAL }}{[. . .}, \ldots]$

* inherits from \setupfootnotes 

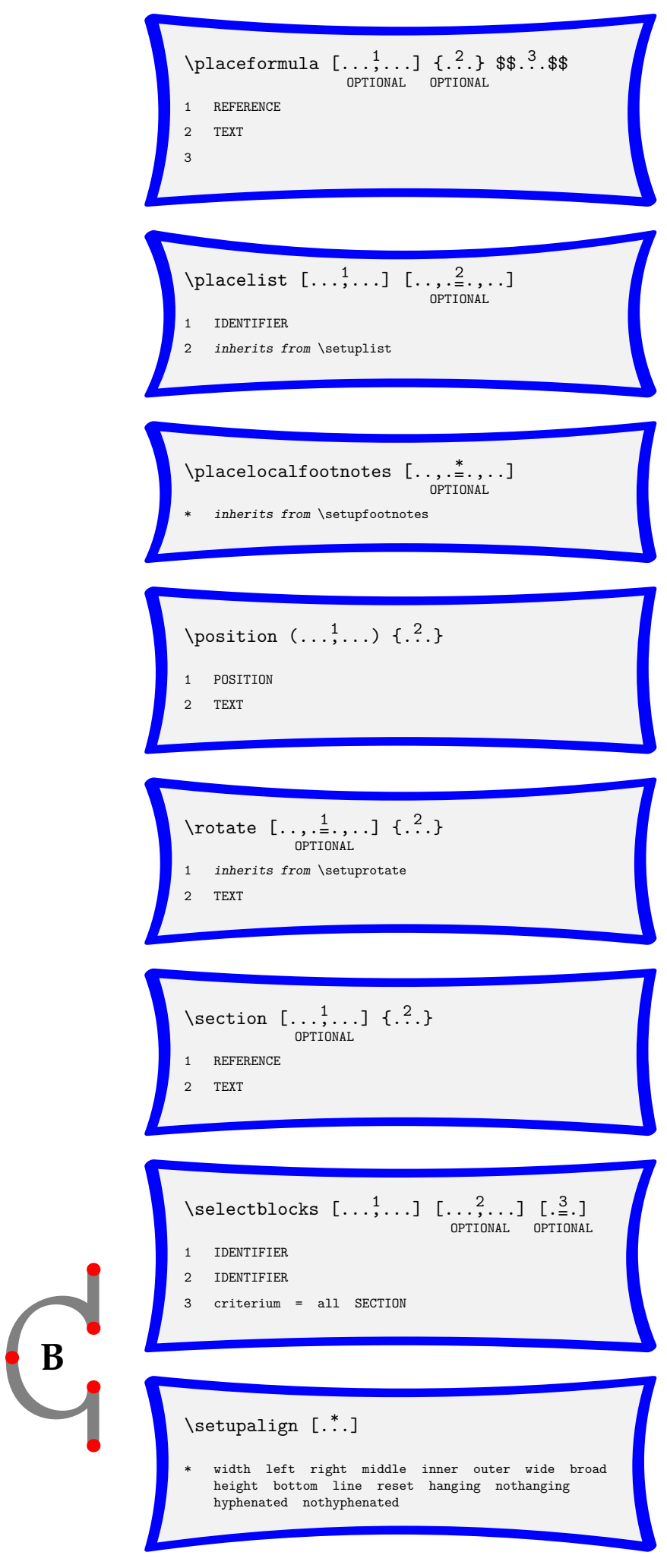

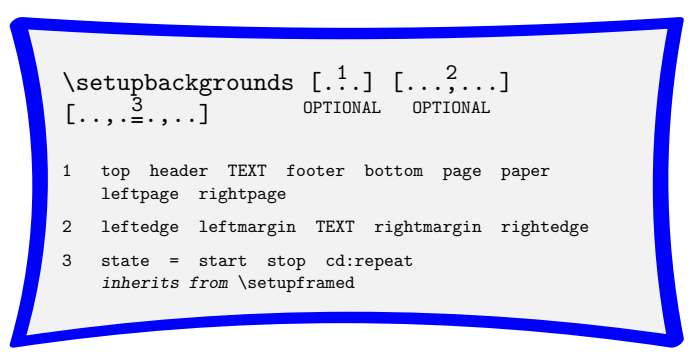

\setupblank $[\ldots]$

\section{OPTIONAL}

* normal standard line DIMENSION big medium small fixed flexible
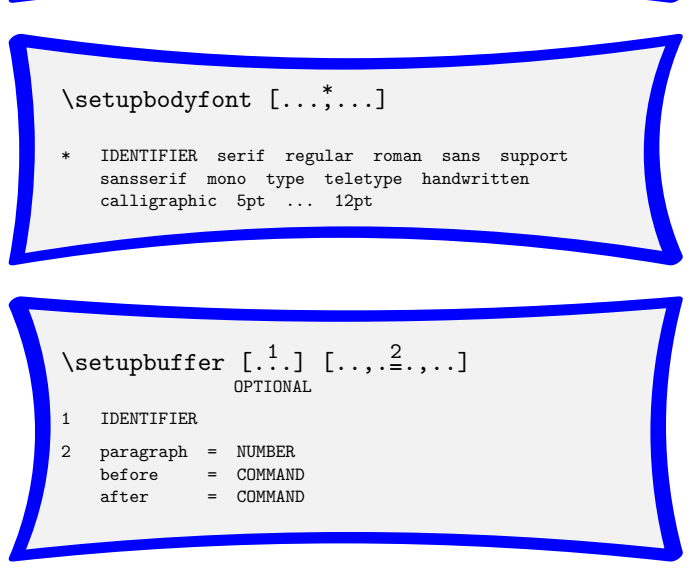

Isetupcaption $[. \stackrel{1}{.}][\ldots, . \stackrel{2}{=}, \ldots]$

1 IDENTIFIER

inherits from \setupcaptions

\setupcaptions $[\ldots, . . * .,$.

* location = top bottom none high low middle width $=f i t$ broad max DIMENSION

minwidth $=$ fit DIMENSION

headstyle = normal bold slanted boldslanted

type cap small... CoMmand

style $=$ normal bold slanted boldslanted

type cap small... Сомма

number $=$ yes no

$\begin{array}{ll}\text { inbetween } & =\text { COMMAND } \\ \text { align } & =\text { inner outer left right middle }\end{array}$

align $=$ inner outer

conversion $=$ numbers characters Characters

romannumerals Romannumerals

way $\quad=$ bytext bycd:section

separator $=$ TEXT

stopper $=$ TEXT

$\begin{array}{ll}\text { command } & =\text { COMMAND } \\ \text { distance } & =\text { DIMENSION }\end{array}$ 

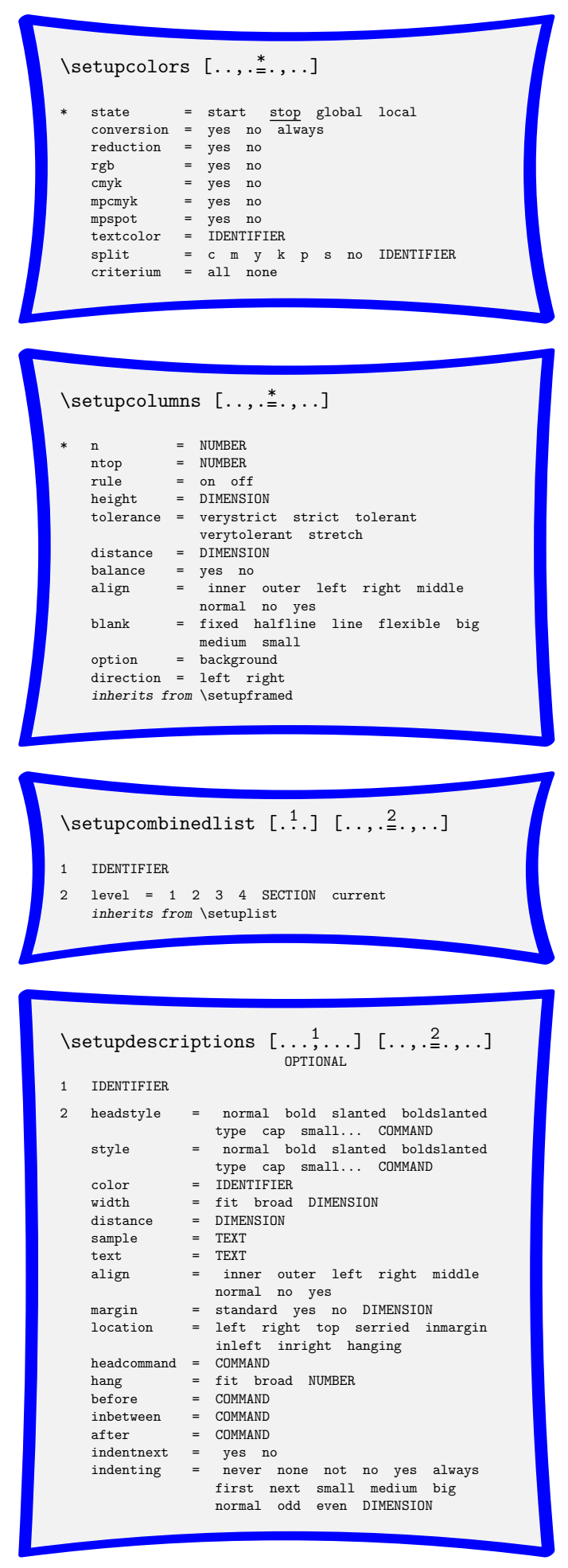
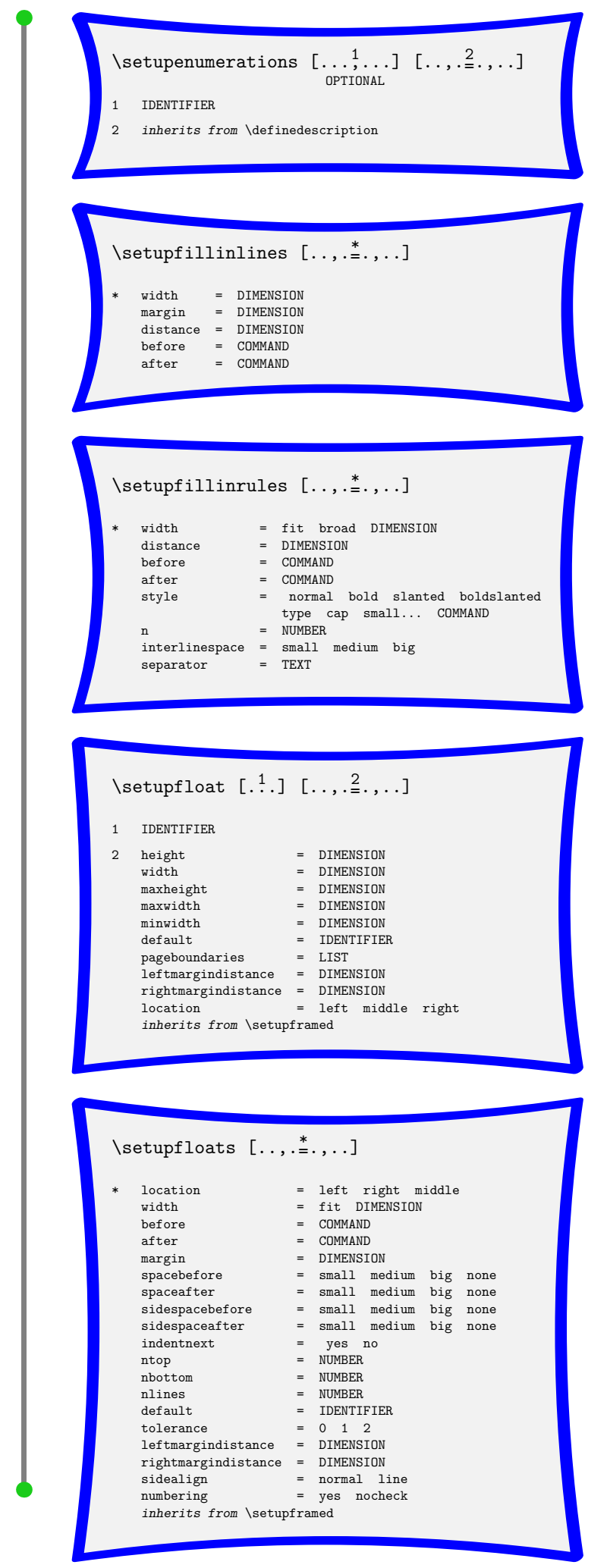

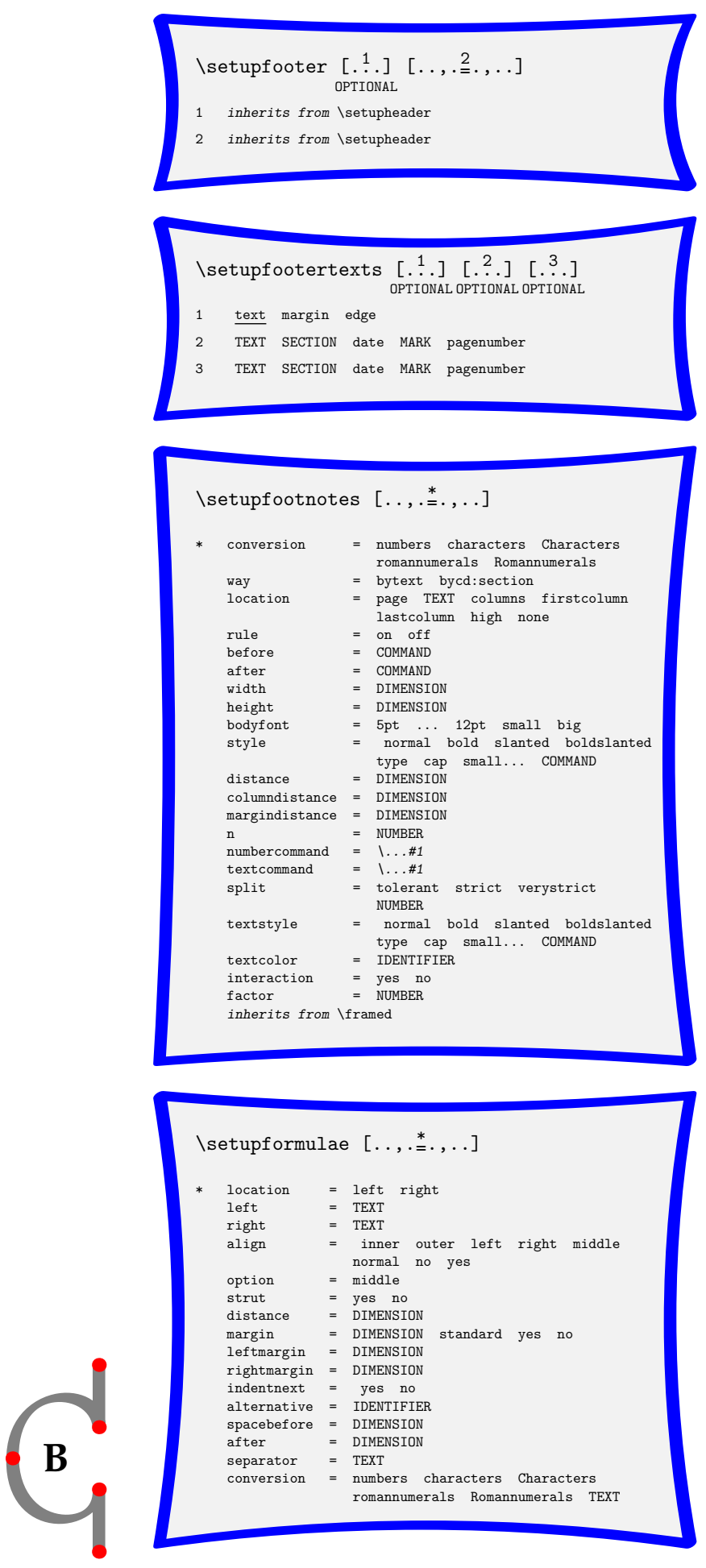
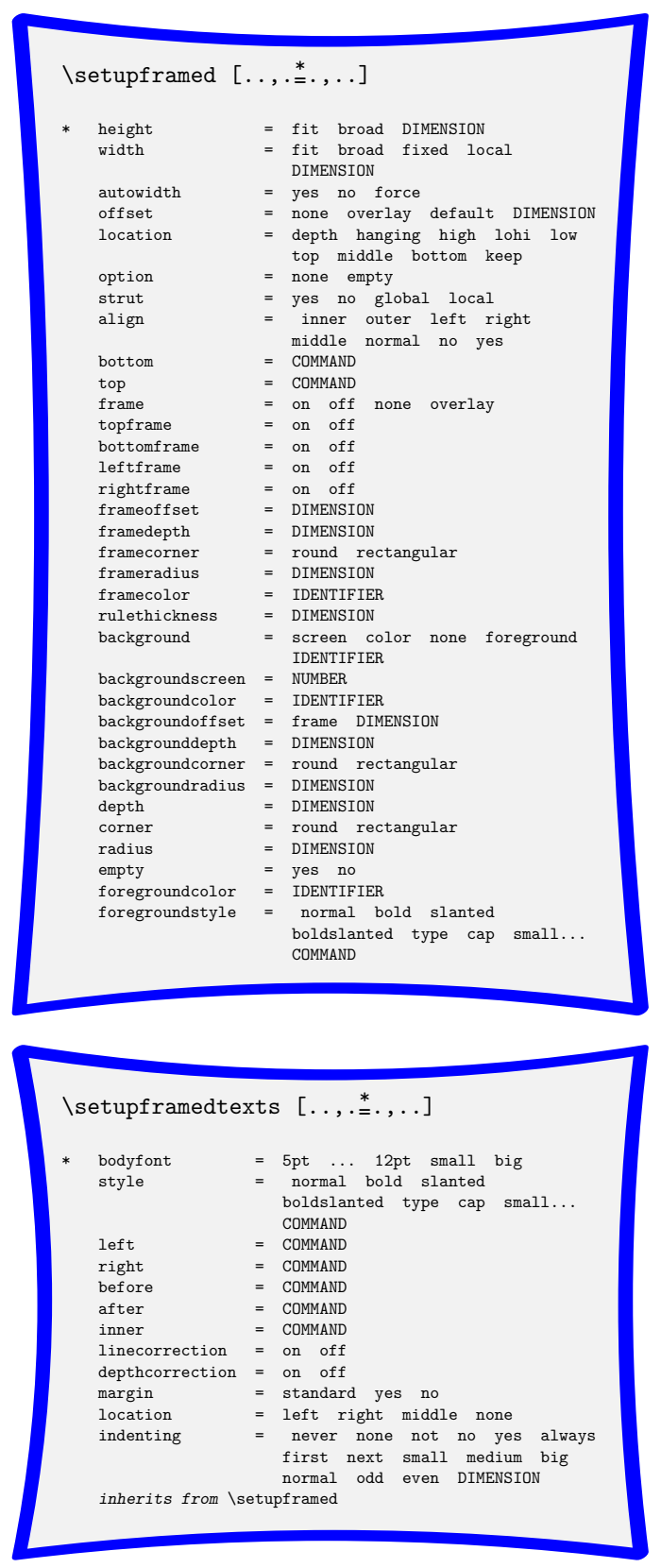

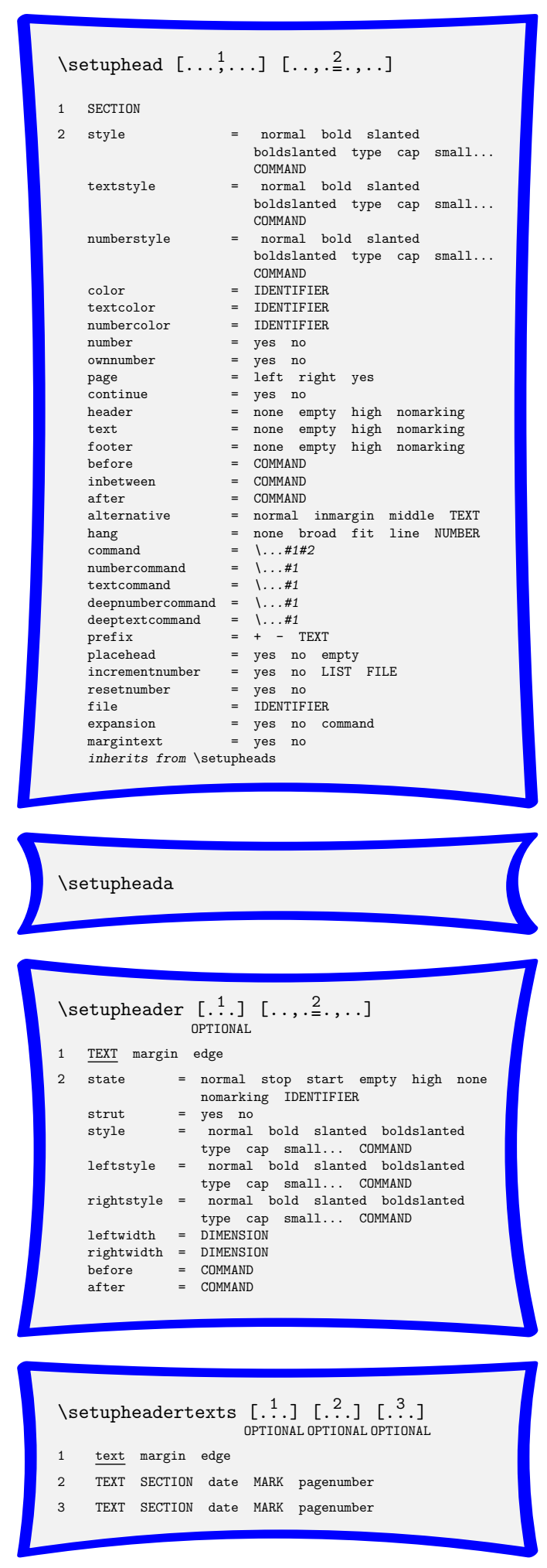
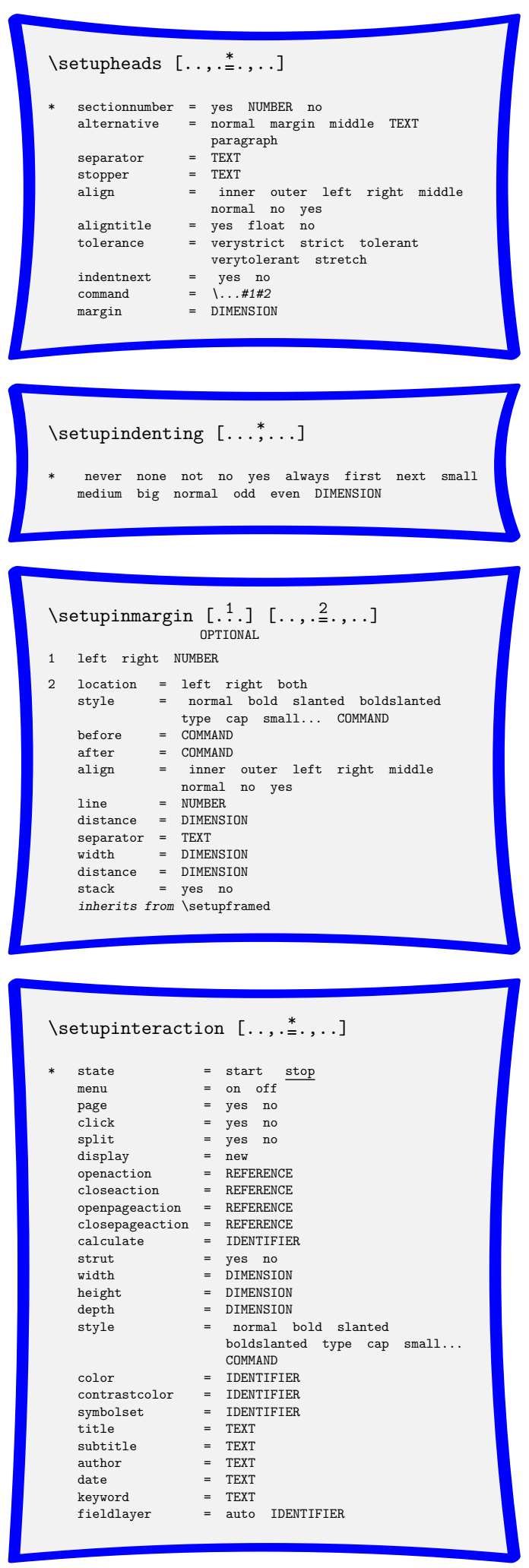

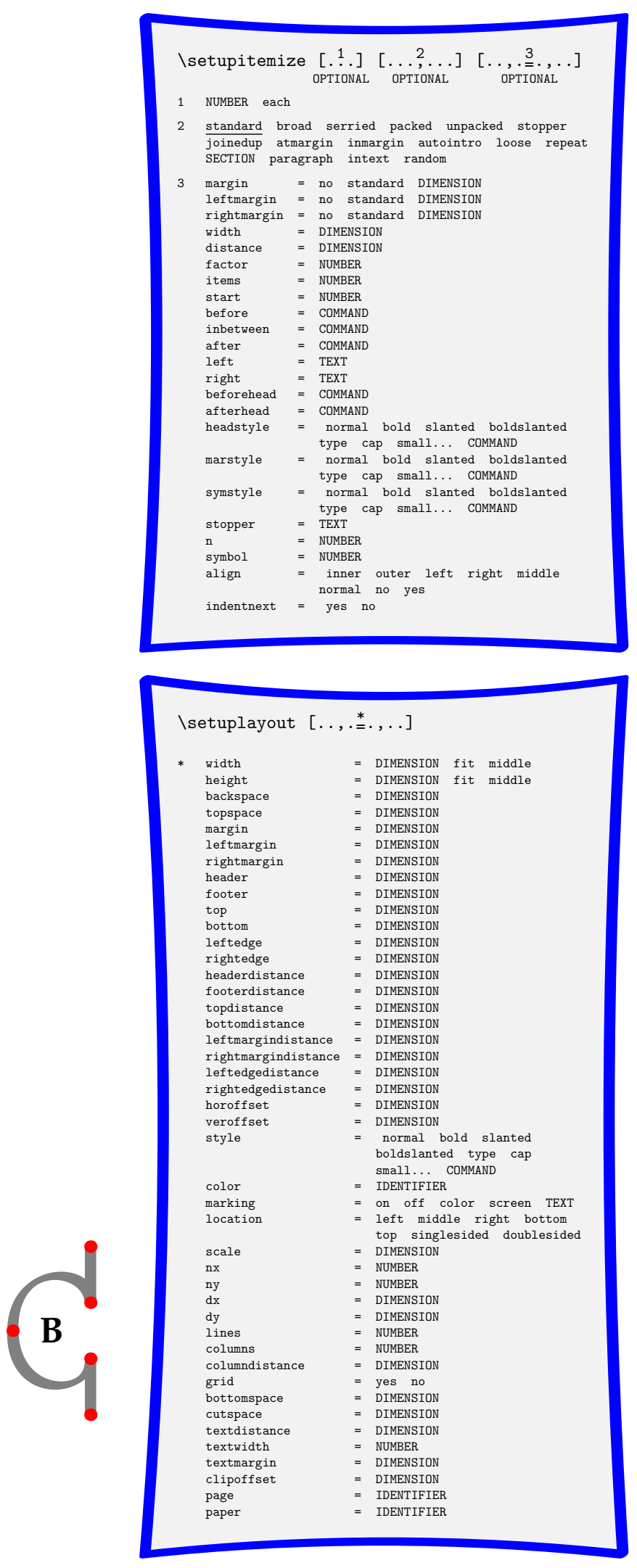
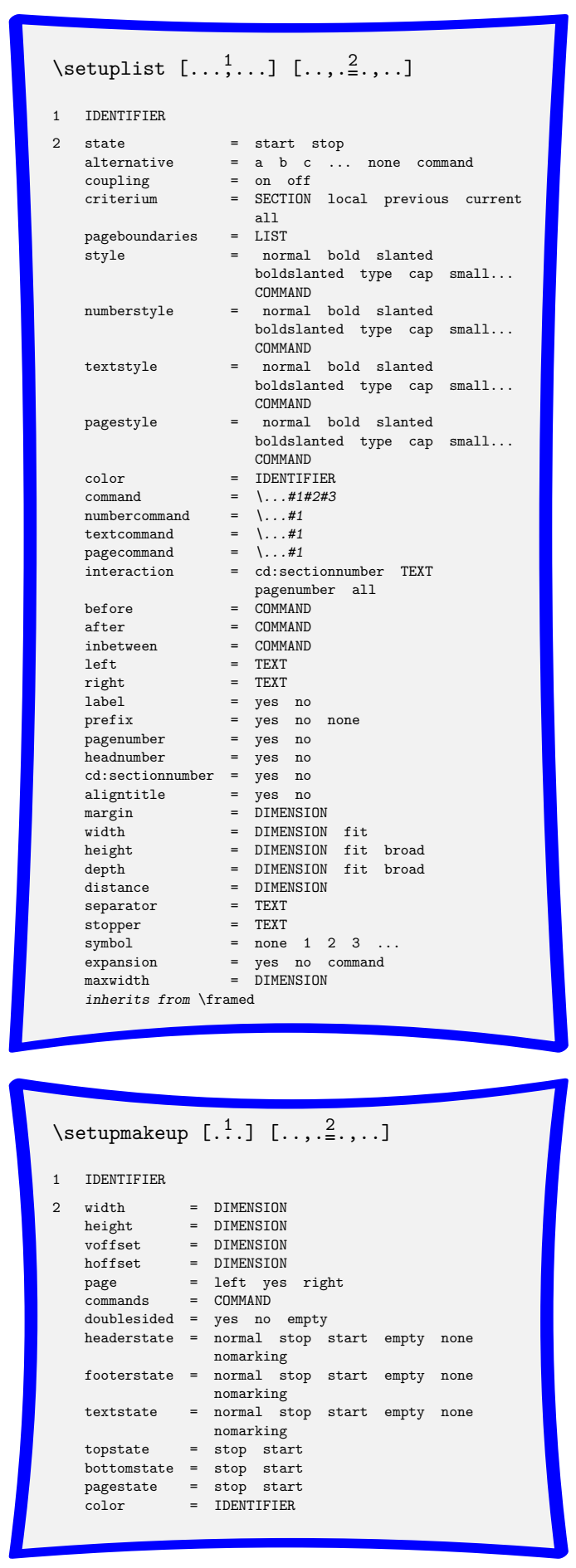

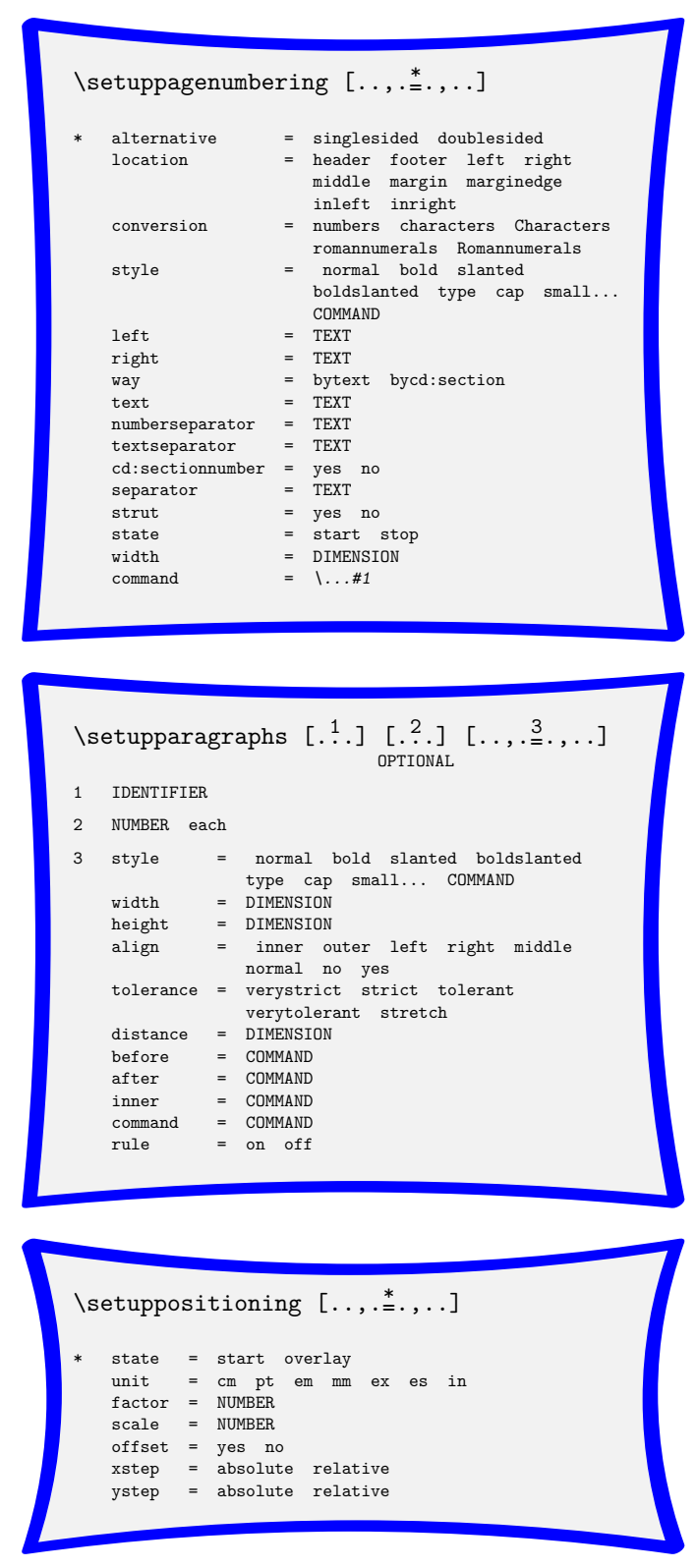
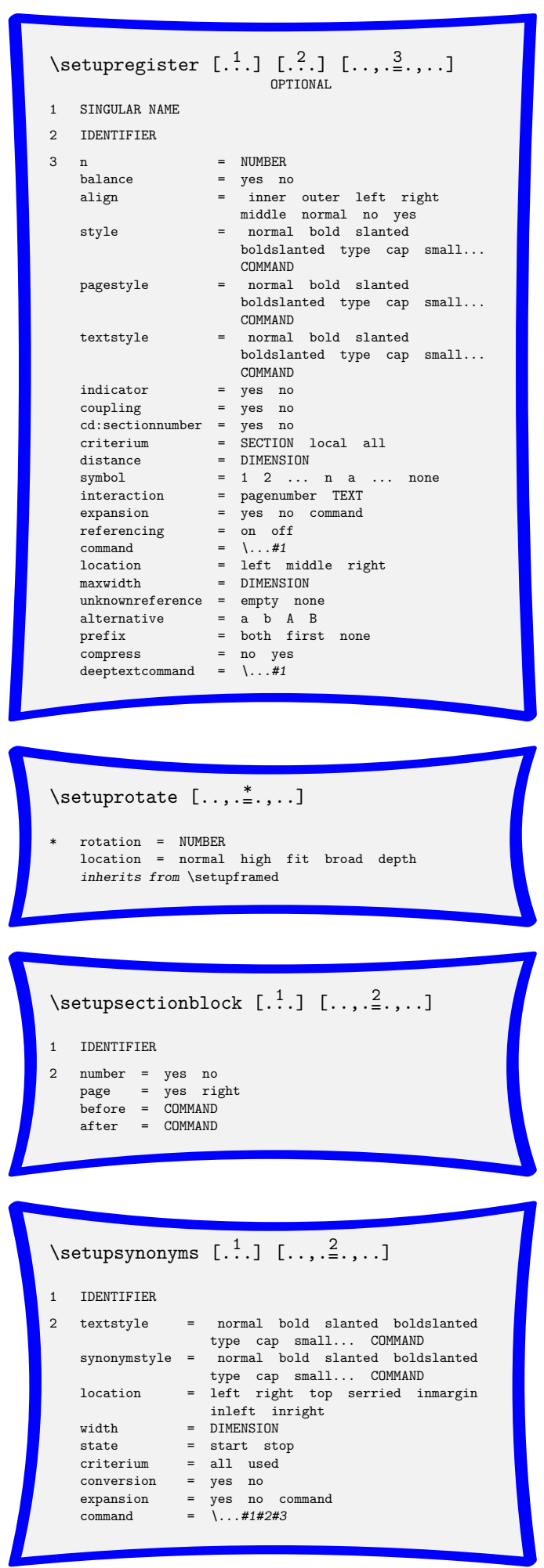

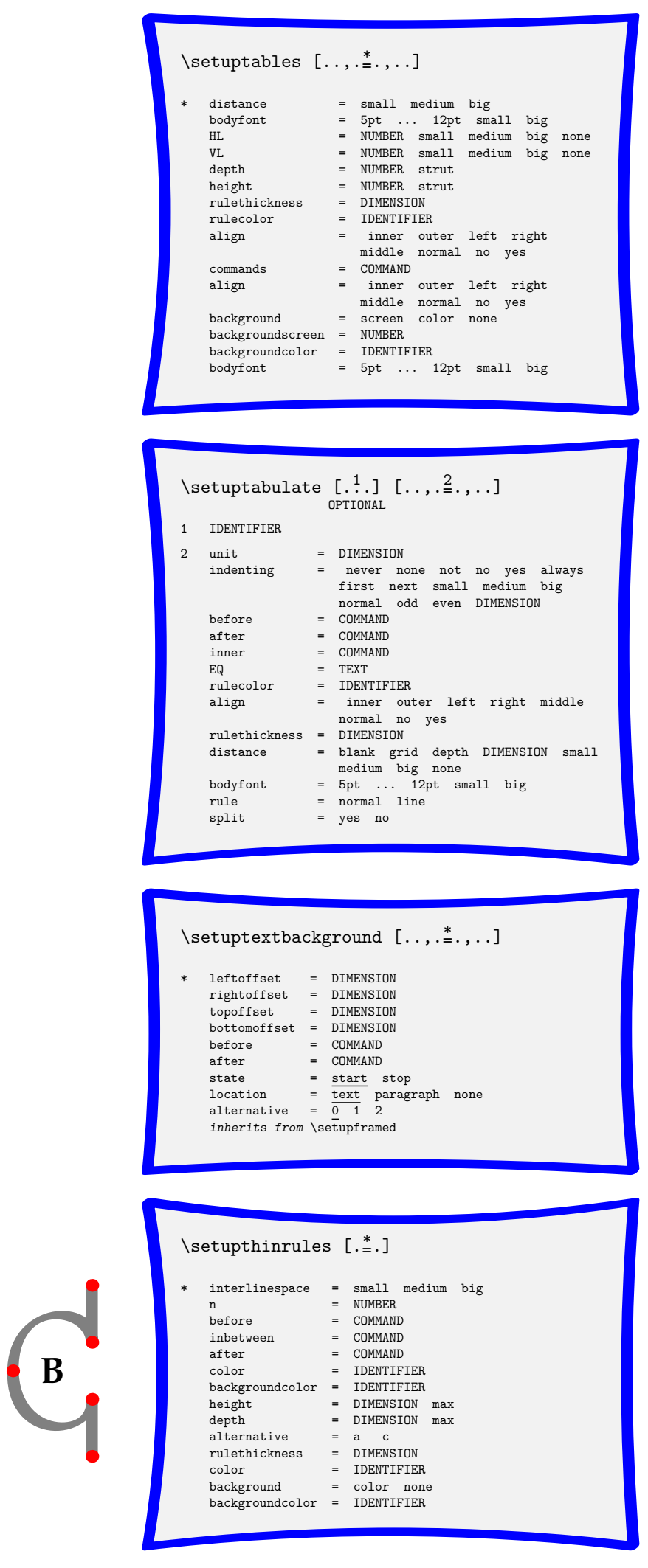
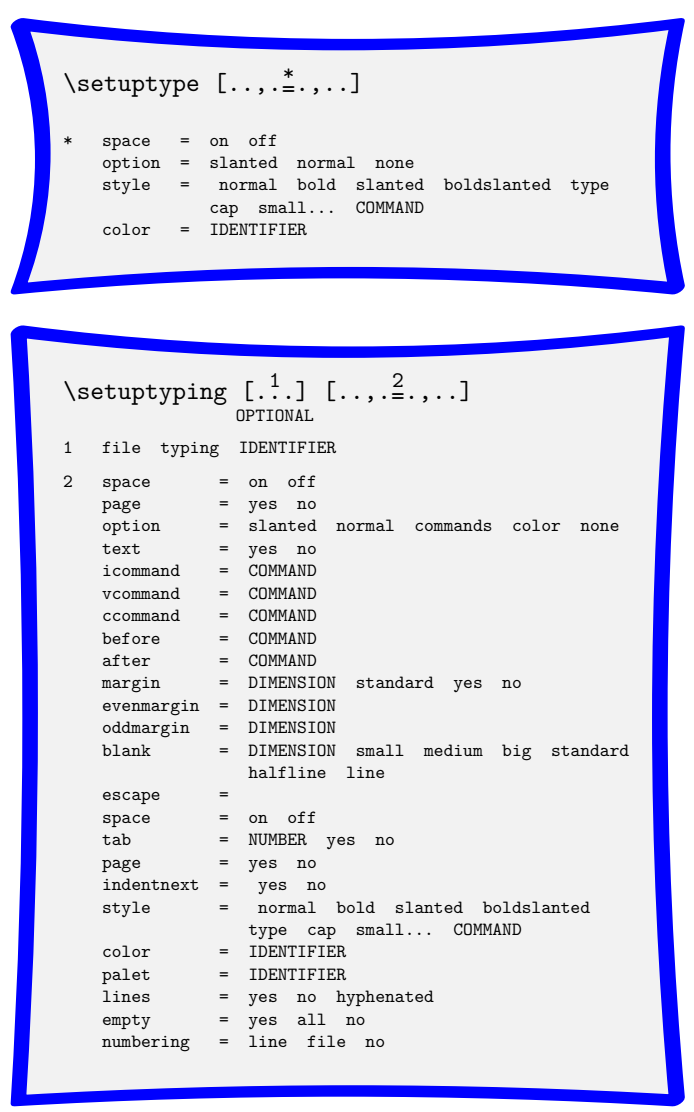

\setupwhitespace $[\ldots$.*.] OPTIONAL

* none small medium big line fixed fix DIMENSION
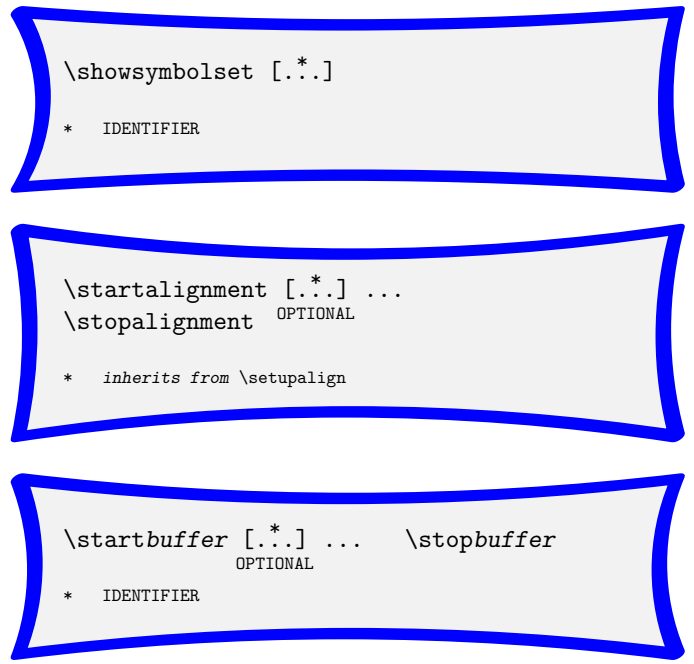

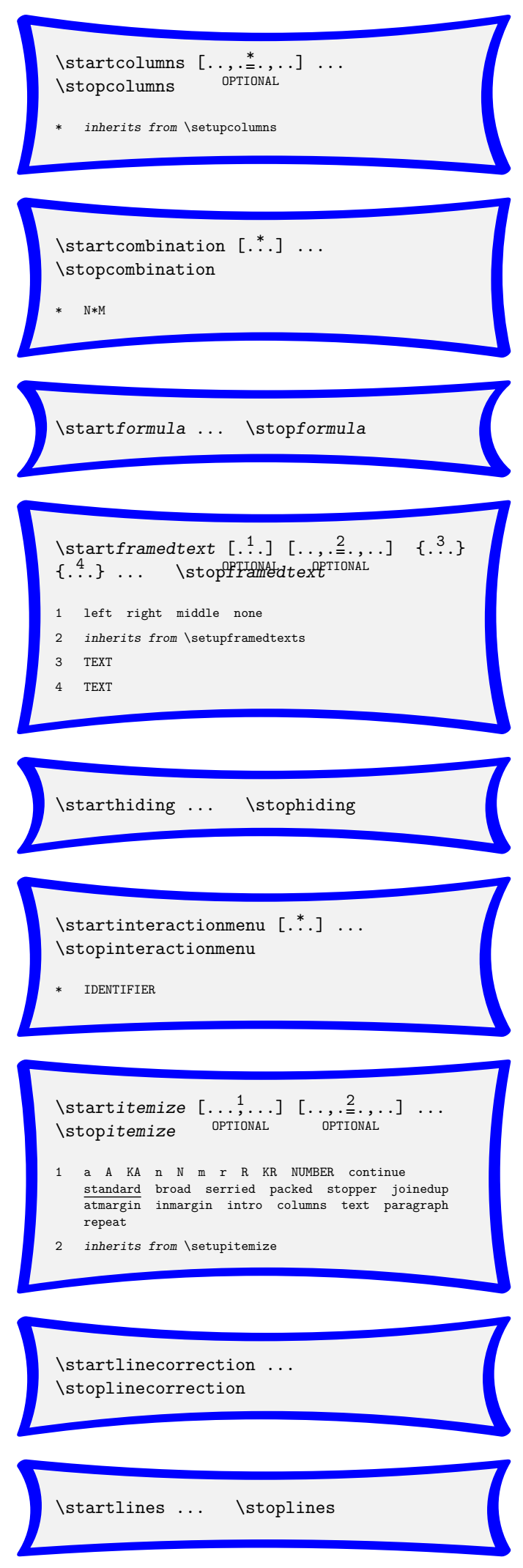

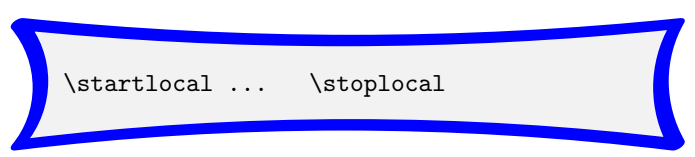

istartlocalfootnotes ...

Istoplocalfootnotes
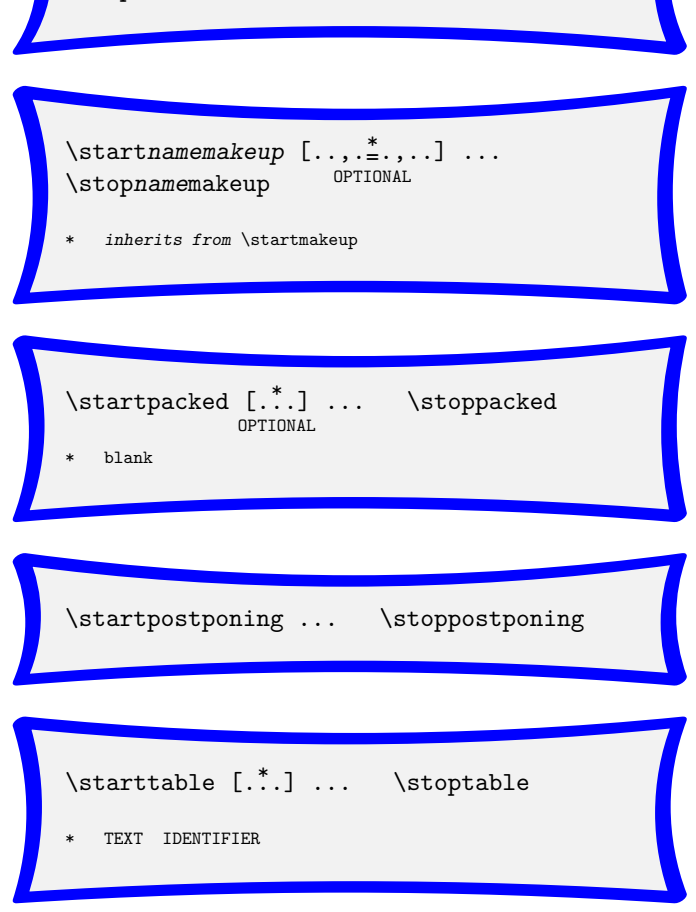

\starttabulate [. $\stackrel{1}{2}] \quad\left[._{2}^{2}.\right] \ldots$

Istoptabulate OPTIONAL OPTIONAL

1 TEXT

2 TEXT
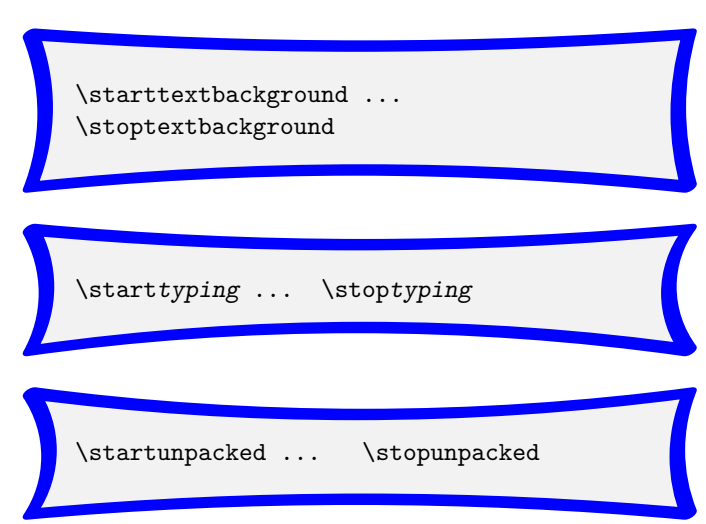

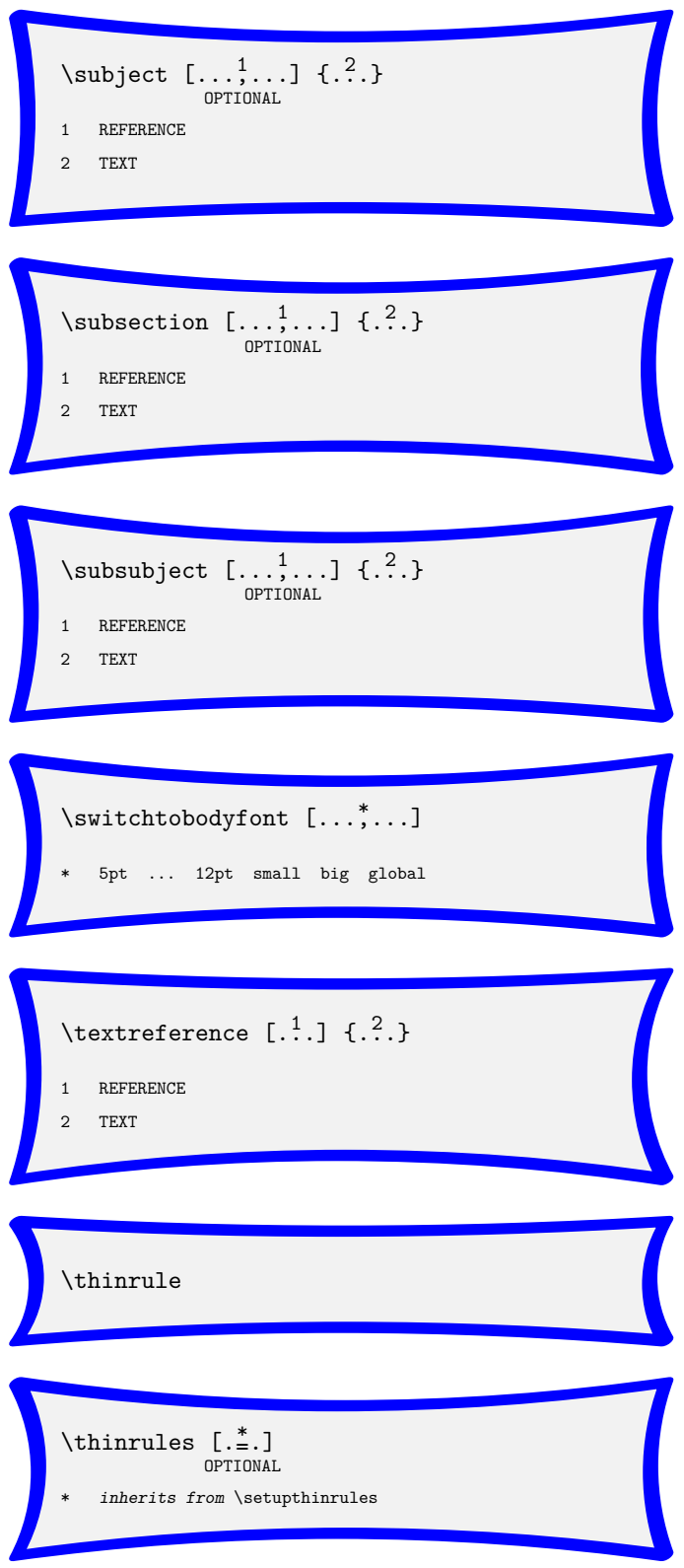

\title $[\ldots 1 \ldots]\{.2$.

1 REFERENCE

2 TEXT
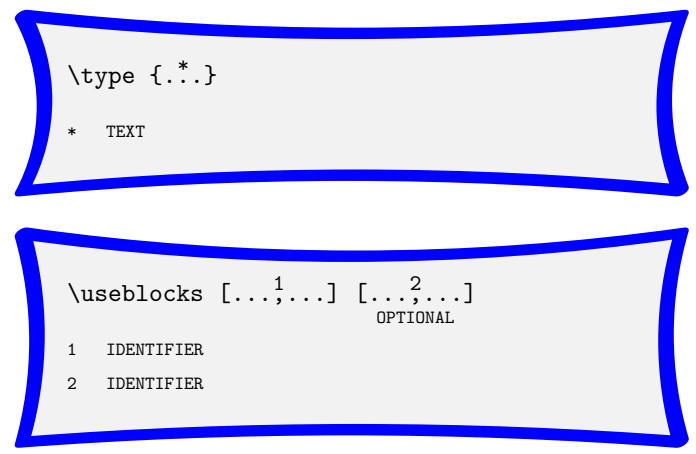

Juseexternaldocument [....] [.2.] $[.3 .$.

1 IDENTIFIER

2 file

TEXT

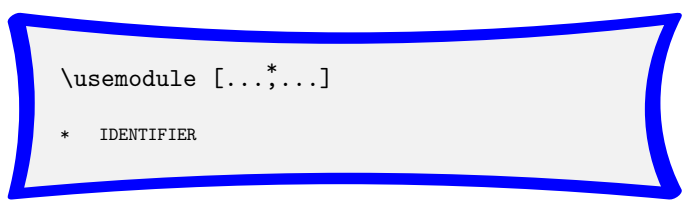

\usesymbols $[. *$. $]$

* IDentifier

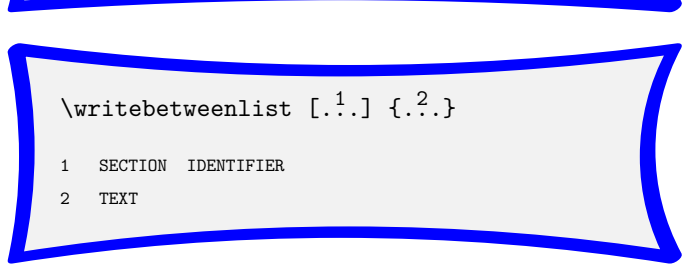

Iwritetolist [...] $\{.2\}.\{.3$.

1 SECTION IDENTIFIER

2 TEXT

TEXT 
\input 119

\inright 61

\it 118

\item 13

$\backslash j a \quad 118$

$\backslash$ language 118

$\backslash$ leftlines 80

\loadabbreviations 72

\lohi 114

\LOW 34

\low 114

$\backslash \mathrm{LR} \quad 34$

$\backslash$ mainlanguage 118,125

\margintitle 61

$\backslash$ midaligned 80

$\backslash$ month 127

$\backslash \mathrm{MR} \quad 34$

$\backslash \mathrm{NC} \quad 34,45$

Inl 118

\no 118

$\backslash$ noheaderandfooterlines 64

\noindenting 101

\nowhitespace 99

$\backslash \mathrm{NR} \quad 34,45$

loverstrikes 112

$\backslash$ page 63

$\backslash$ pagereference 74

$\backslash$ par 98

$\backslash$ paragraph 10,98

\percent 27

$\backslash$ periods 112

$\backslash$ permille 27

$\backslash$ pl 118

$\backslash$ placecontent 66

$\backslash$ placefigure 28

$\backslash$ placeformula 23

$\backslash$ placeindex 71

$\backslash$ placeintermezzo 107

$\backslash$ placelistofabbreviations 72

Iplaceregister 71

$\backslash$ placetable 34

\position 115 $\backslash$ pt $\quad 118$

\quotation 127

Iquote 127

$\backslash$ rightaligned 80

$\backslash \mathrm{rm} 88$

Iro 118

Irotate 116

\ru 118

\setupalign 80

$\backslash$ setupbackgrounds 79

$\backslash$ setupblank 99

$\backslash$ setupblock 110

$\backslash$ setupbodyfont $86,91,126$

$\backslash$ setupbuffer 111

Isetupcaption 107

Isetupcaptions 28,34,107

Isetupcolors 77

$\backslash$ setupcolumns 48

$\backslash$ setupcombinedlist 66

\setupdescriptions 53

Isetupenumerations 55

$\backslash$ setupfigures 28

$\backslash$ setupfillinlines 112

\setupfillinrules 112

Isetupfloat 107

\setupfloats 28,34,107

$\backslash$ setupfooter 64

$\backslash$ setupfootertexts 64

Isetupfootnotes 50

Isetupformulae 23

$\backslash$ setupframed 57

$\backslash$ setupframedtext 59

Isetuphead 10

Isetupheader 64

$\backslash$ setupheadertexts 64

$\backslash$ setupheads 10

\setupheadtext 127

\setupindenting 101

Isetupinteraction 82

$\backslash$ setupitemize 13

$\backslash$ setuplayout 94

$\backslash$ setuplist 66

$\backslash$ setupmakeup 106

\setupmargin 61

$\backslash$ setupositioning 115 


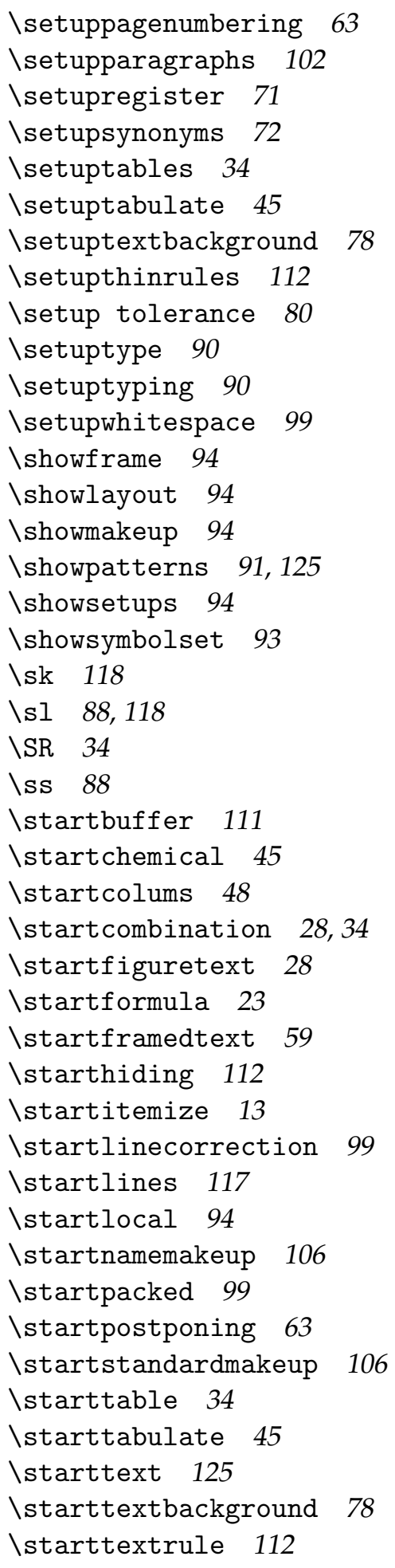

\starttyping 90

\startunpacked 99

\stoptext 125

\subject 10

\subparagraph 10

$\backslash$ subsubject 10

\sv 118

\switchtobodyfont 86

$\backslash$ texteuro 93

$\backslash$ tfa 88

$\backslash \mathrm{tfb} \quad 88$

$\backslash$ tfc 88

$\backslash$ tfd 88

$\backslash$ thinrule 112

$\backslash$ thinrules 112

$\backslash$ THREE 34

\title 10

\tr 118

tet 88

$\backslash$ TWO 34

type 90

\typebuffer 111

\ua 118

\uk 118

\underbar 112

\unit 27,72

\us 118

\useblocks 110

\useencoding 126

\useexternaldocument 83

\usemodule 119

\usesymbols 93

\usetypescript 91,126

\VL 34

\vn 118

\weekday 127

$\backslash$ whitespace 99

\writebetweenlist 66

\writetolist 66 


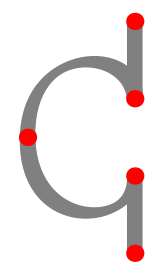


Rejstř́k

\section{Rejstř́ik}

a

akcenty 93

AMS 86

AMSmath 119

\section{b}

barva 77

barva pozadí 78

bibliografie 119

blok textu 110

\section{c}

Computer Modern 86 cont-sys.tex 123

Courier 126

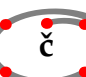

čeština 125

číslované poznámky 55

číslování stránek 63

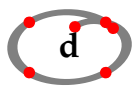

datum 115,127

definice

pojmů 53

př́kazů a maker 103

den v týdnu 127

dělění slov 118

display mód 19

Acrobat Distiller 81

dolní index 114

dvi-soubor 7

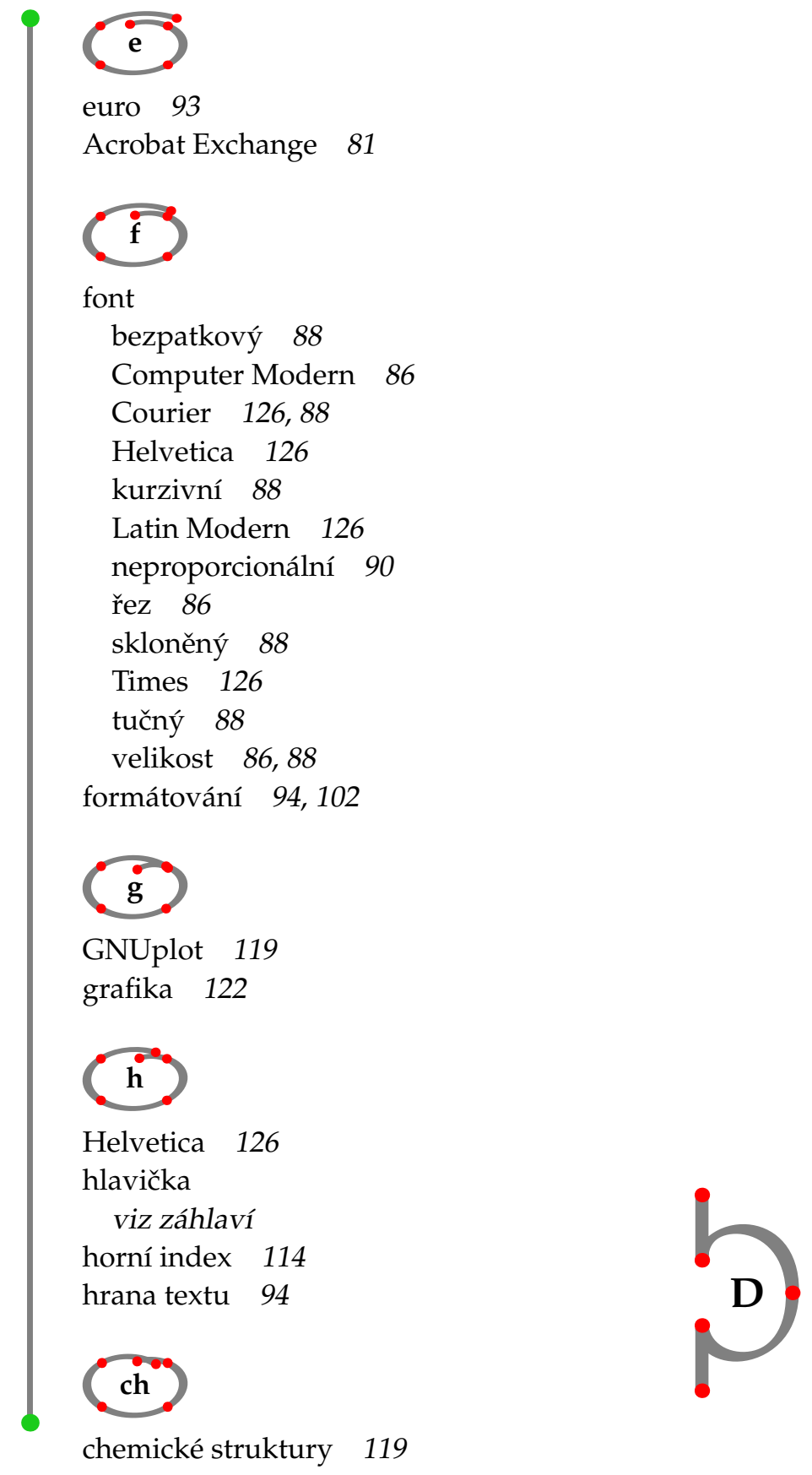


Rejstř́ik
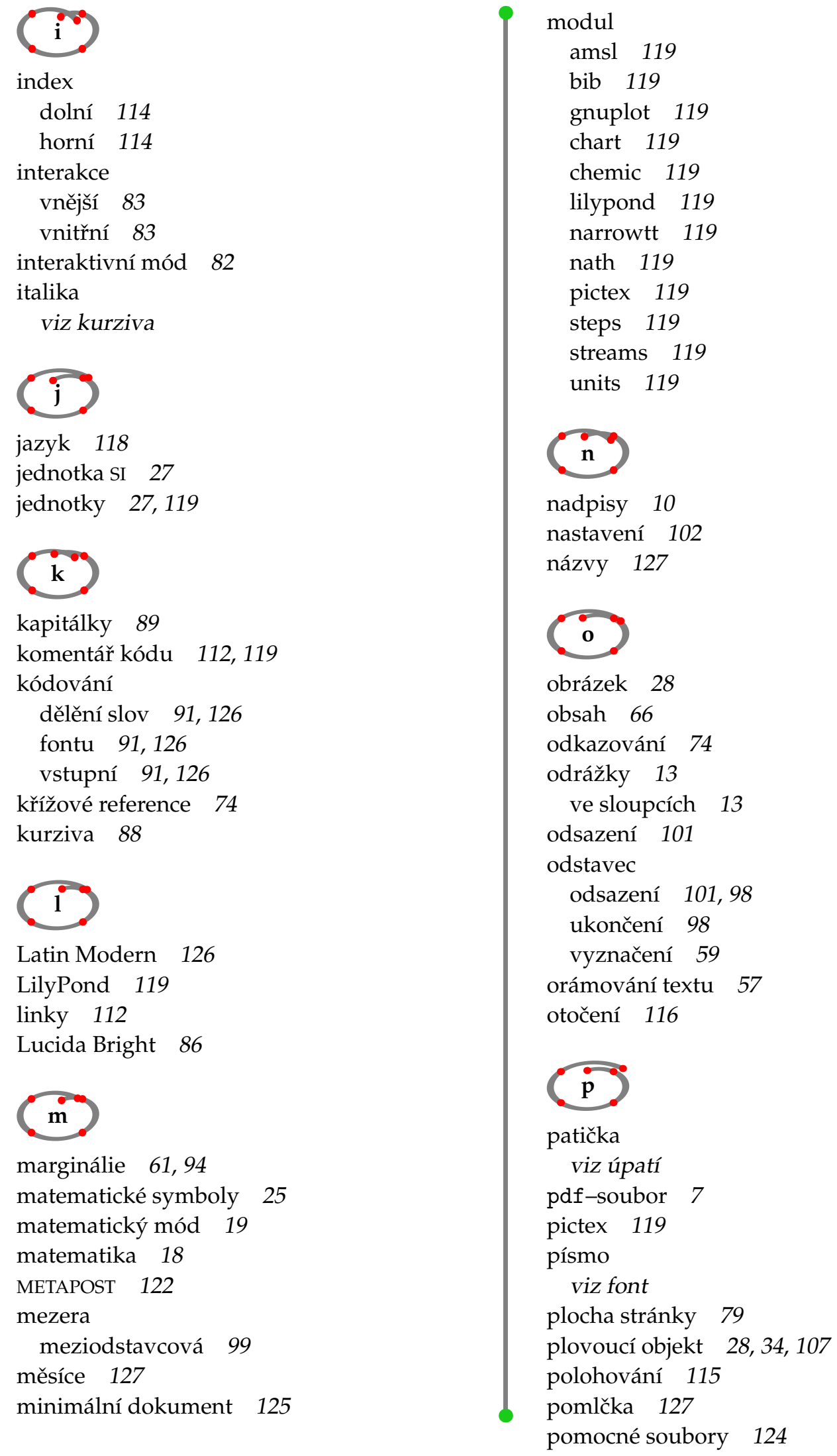

nadpisy 10

nastavení 102

názvy 127

\section{o}

obrázek 28

obsah 66

odkazování 74

odrážky 13

ve sloupcích 13

odsazení 101

odstavec

odsazení 101, 98

ukončení 98

vyznačení 59

orámování textu 57

otočení 116

\section{p}

patička

viz úpatí

pdf-soubor 7

pictex 119

písmo

viz font

plocha stránky 79

plovoucí objekt $\quad 28,34,107$

polohování 115

pomlčka 127

pomocné soubory 124 


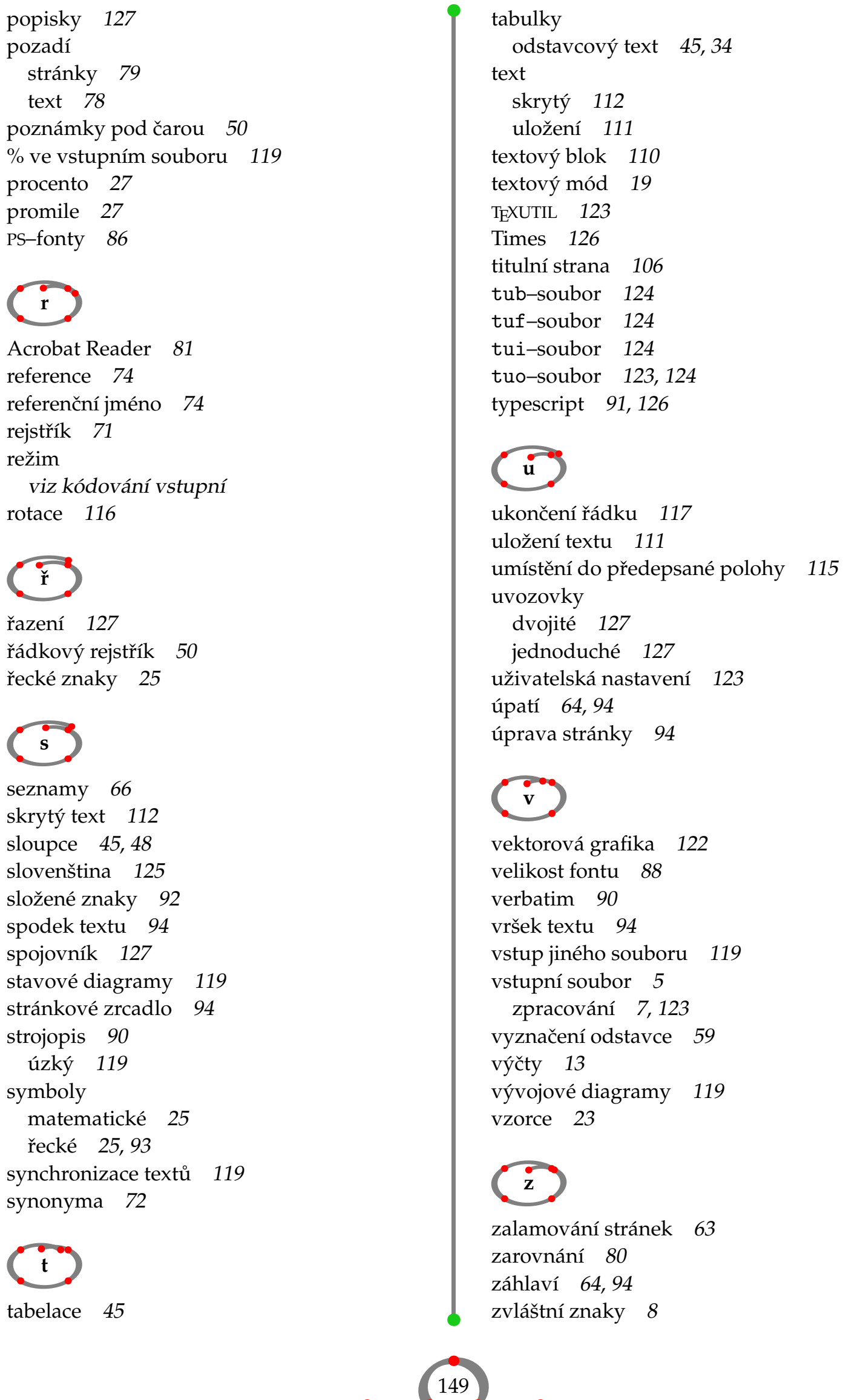

řazení 127

řádkový rejstřík 50

řecké znaky 25

$\mathbf{s}$

seznamy 66

skrytý text 112

sloupce 45,48

slovenština 125

složené znaky 92

spodek textu 94

spojovník 127

stavové diagramy 119

stránkové zrcadlo 94

strojopis 90

úzký 119

symboly

matematické 25

řecké 25, 93

synchronizace textů 119

synonyma 72

t

tabelace 45

tabulky

odstavcový text 45,34

text

skrytý 112

uložení 111

textový blok 110

textový mód 19

TEXUTIL 123

Times 126

titulní strana 106

tub-soubor 124

tuf-soubor 124

tui-soubor 124

tuo-soubor 123, 124

typescript 91,126

\section{u}

ukončení řádku 117

uložení textu 111

umístění do předepsané polohy 115

uvozovky

dvojité 127

jednoduché 127

uživatelská nastavení 123

úpatí 64,94

úprava stránky 94

\section{$\mathbf{v}$}

vektorová grafika 122

velikost fontu 88

verbatim 90

vršek textu 94

vstup jiného souboru 119

vstupní soubor 5

zpracování 7,123

vyznačení odstavce 59

výčty 13

vývojové diagramy 119

vzorce 23

\section{$\mathbf{Z}$}

zalamování stránek 63

zarovnání 80

záhlaví 64, 94

zvláštní znaky 8 
Rejstř́ik

zvýraznění 89

8

D 


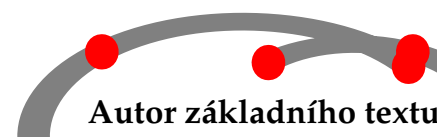

Ton Otten

\section{Překlad}

Vít Zýka, Ján Buša, Jiří Hrbek, Martina Plachá a Petr Tesařík

Design a typografie

Hans Hagen
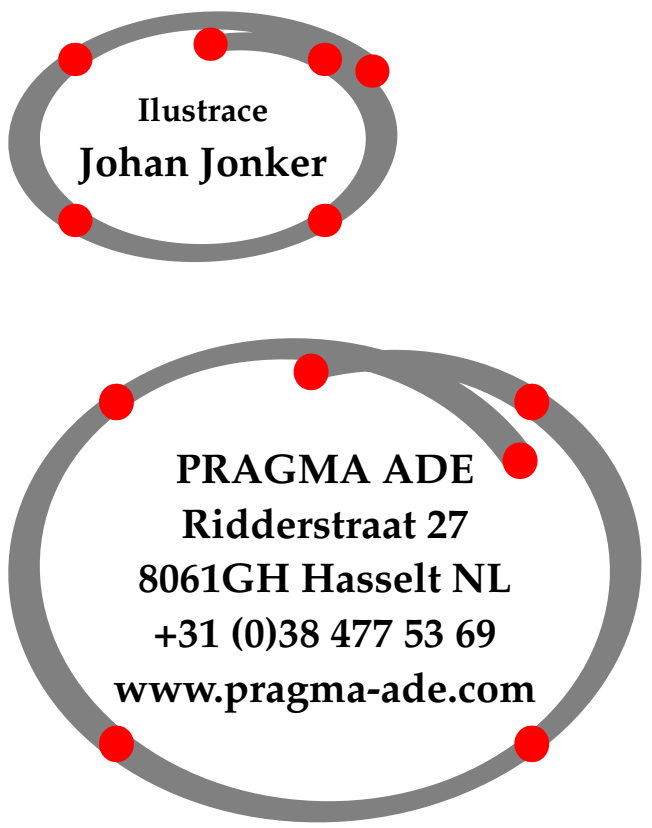

6. prosince 2006 


